\title{
Synthesis, Characterization and Properties of Near Infrared-Active Ruthenium Complexes and Polymers
}

\author{
By \\ Shidi Xun \\ A thesis submitted to \\ the Faculty of Graduate Studies and Research \\ in partial fulfillment of the requirements for the degree of \\ Doctor of Philosophy \\ Department of Chemistry \\ Carleton University \\ Ottawa, Ontario, Canada
}

August 2008

(C) Copyright, Shidi Xun, Ottawa, Canada, 2008 


$\begin{array}{ll}\begin{array}{l}\text { Library and } \\ \text { Archives Canada }\end{array} & \begin{array}{l}\text { Bibliothèque et } \\ \text { Archives Canada }\end{array} \\ \begin{array}{l}\text { Published Heritage } \\ \text { Branch }\end{array} & \begin{array}{l}\text { Direction du } \\ \text { Patrimoine de l'édition }\end{array} \\ \begin{array}{l}\text { 395 Wellington Street } \\ \text { Ottawa ON K1A 0N4 } \\ \text { Canada }\end{array} & \begin{array}{l}\text { O95, rue Wellington } \\ \text { Ottawa ON K1A 0N4 } \\ \text { Canada }\end{array}\end{array}$

Your file Votre référence

ISBN: 978-0-494-43918-0

Our file Notre référence

ISBN: 978-0-494-43918-0

NOTICE:

The author has granted a nonexclusive license allowing Library and Archives Canada to reproduce, publish, archive, preserve, conserve, communicate to the public by telecommunication or on the Internet, loan, distribute and sell theses worldwide, for commercial or noncommercial purposes, in microform, paper, electronic and/or any other formats.

The author retains copyright ownership and moral rights in this thesis. Neither the thesis nor substantial extracts from it may be printed or otherwise reproduced without the author's permission.
AVIS:

L'auteur a accordé une licence non exclusive permettant à la Bibliothèque et Archives Canada de reproduire, publier, archiver, sauvegarder, conserver, transmettre au public par télécommunication ou par l'Internet, prêter, distribuer et vendre des thèses partout dans le monde, à des fins commerciales ou autres, sur support microforme, papier, électronique et/ou autres formats.

L'auteur conserve la propriété du droit d'auteur et des droits moraux qui protège cette thèse. $\mathrm{Ni}$ la thèse ni des extraits substantiels de celle-ci ne doivent être imprimés ou autrement reproduits sans son autorisation.
In compliance with the Canadian

Privacy Act some supporting forms may have been removed from this thesis.

While these forms may be included in the document page count, their removal does not represent any loss of content from the thesis.
Conformément à la loi canadienne sur la protection de la vie privée, quelques formulaires secondaires ont été enlevés de cette thèse.

Bien que ces formulaires aient inclus dans la pagination, il n'y aura aucun contenu manquant.

\section{Canada}




\section{Abstract}

Near-infrared (NIR)-active materials are of technological interest for their potential applications in telecommunications, information storage, and biology sensors and for military purposes. This thesis consists of three parts with an overall objective of studying NIR-active ruthenium complexes and polymers, in particular the NIR electrochromism (chapter 2) and PL and EL properties (chapter 3) of the ruthenium complexes, and the photophysical properties of the ruthenium and other metal complex polymers (chapter 4).

First, to better understand the correlation between the structures and electrochemical and photophysical properties, four dinuclear ruthenium complexes with 1,2-dicarbonylhydrazido bridging ligand (DCH-Ru) with electron-withdrawing or electron-donating substituents are designed and synthesized. The resulting complexes show reversible redox properties and NIR electrochromism in the spectral region of 1150 to $1600 \mathrm{~nm}$. The low oxidation potential and strong NIR absorption at $1150 \mathrm{~nm}$ are utilized to detect hydrogen peroxide in vitro at concentrations as low as $0.1 \mathrm{mM}$. Further utilization of energy transfer between a fluorescent dye and DCH-Ru complexes in different oxidation states, the electrochemically controlled photoluminescence is achieved.

Second, efforts have been made to extend ruthenium complex-based light emission beyond $1 \mu \mathrm{m}$ by adjusting the LUMO level of the ligands and HOMO level of the metal center in complexes. Tunable photoluminescence and 
electroluminescence from 630 to $1040 \mathrm{~nm}$ have been achieved.

Third, a new series of polypyridyl-containing polymers and their metal complexes are obtained for studying their photophysical response to acid and some transition metal ions and NIR properties. Good selectivity and high sensitivity (e.g., $5 \mathrm{ppm}$ level) for silver and palladium ions with these polypyridyl-containing polymers have been found. 


\section{Acknowledgements}

This Ph.D. thesis was established in the organic optoelectronics research group at Carleton University, and would not have been what it is today without the support and advice of others.

First of all I would like to thank my supervisor, Professor Zhi Yuan Wang, for the opportunity he has given to me by receiving me in his group to pursue my Ph.D. degree, for all his guidance and advice throughout this project, and the five years of our working relationship. His ideas and guidance have been invaluable.

Many thanks to all the Ph.D. students, master students and post-docs in our lab who made life more enjoyable during my time at Carleton. Their support and friendship will be appreciated always. Also, I would like to thank Dr. Jane Gao for her assistance and encouragement.

I would like to thank my parents, Wanxiang Xun and Jingfang Hu, for their constant encouragement during my upbringing. The values and characters that they helped to foster have been the greatest gift I could ever hope for.

A special thank to my wife, Zhiyin Xun, for her love, support and understanding during all these five years. I look forward to our future together. 


\section{Table of Contents}

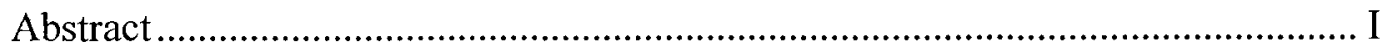

Acknowledgements............................................................................................II

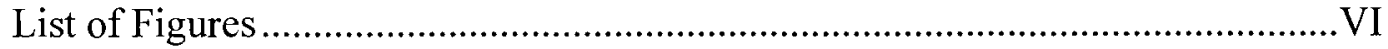

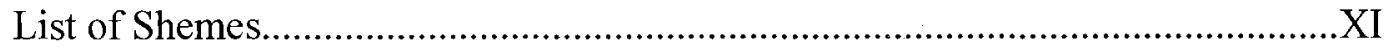

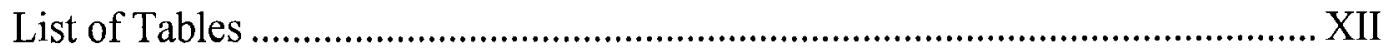

List of Symbols and Abbreviations................................................................

Chapter 1 Introduction to Near Infrared Organic Materials...................... 1

$1.1 \quad$ NIR redox-active metal complexes..................................................

1.1.1 Planar dithiolene complexes of $\mathrm{Ni}, \mathrm{Pd}$ and $\mathrm{Pt}$.........................

1.1.2 Tris(pyrazolyl)borato-molybdenum complexes....................... 4

1.1.3 Ruthenium dioxolene complexes..........................................

1.1.4 Mixed-valence dinuclear ruthenium complexes....................10

$1.2 \quad$ NIR electroluminescent materials...................................................13

1.2.1 Organic rare-earth complexes ................................................

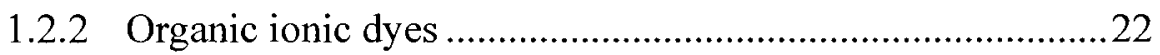

1.2.3 Conjugated polymers .............................................................24

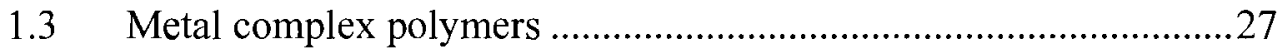

1.3.1 Metal complexes in conjugated main chain.........................28

1.3.2 Conjugated polymers with pendant metal complexes ............35

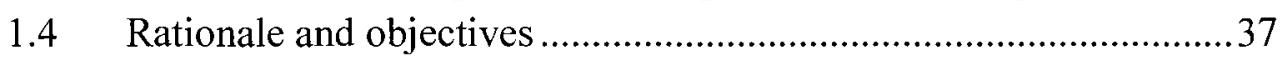

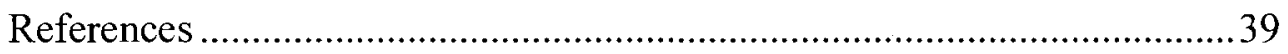

Chapter 2 Design, Synthesis, and Stimulus-Responsive Properties of

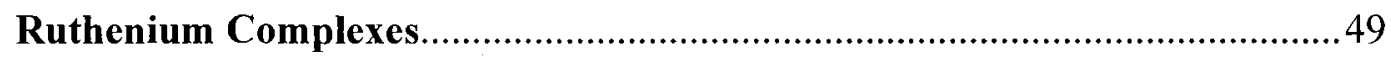

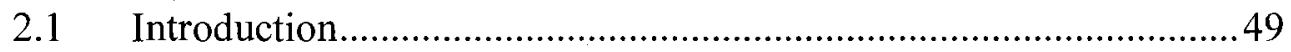

2.1 Synthesis and characterization of DCH-Ru complexes.....................50

$2.4 \quad \mathrm{H}_{2} \mathrm{O}_{2}$-responsive NIR properties....................................................57

2.5 Redox-responsive PL based on DCH-Ru complexes ........................60

2.5.1 Absorption, photoluminescent and electrochemical properties

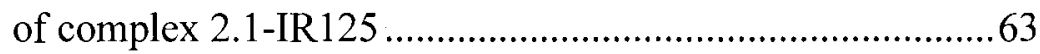

2.5.2 Absorption, photoluminescent and electrochemical properties

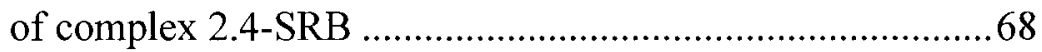

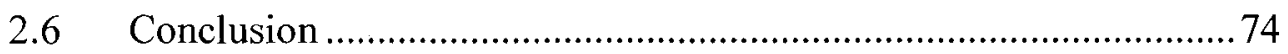


2.7 Experiments .74

References

\section{Chapter 3 Design, Synthesis and Near-Infrared Photoluminescent and} Electroluminescent Properties of Ruthenium Complexes.

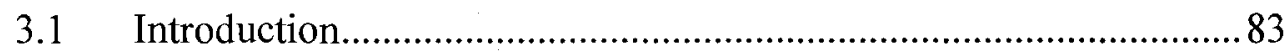

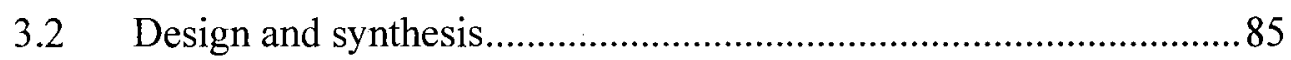

3.3 Results and discussions...............................................................91

3.3.1 Optical properties................................................................91

3.3.2 Electrochemical properties ...................................................93

3.3.3 Electroluminescent properties.................................................97

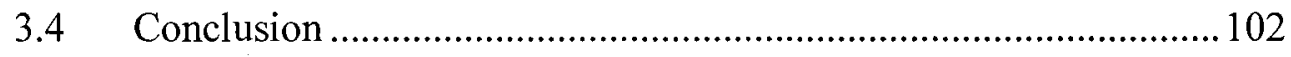

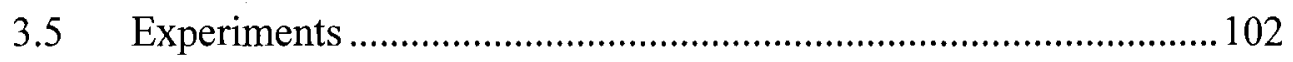

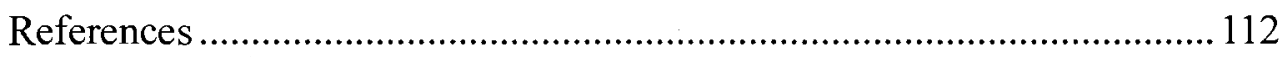

Chapter 4 Synthesis and Characterizations of 2,3-Bis(2-pyridyl)benzoquinoxaline-Containing Polymers and Complexation

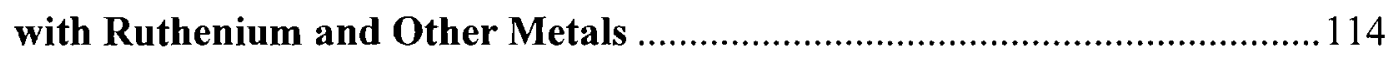

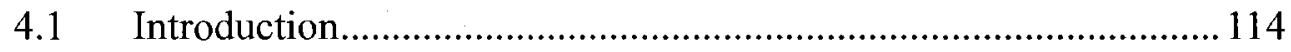

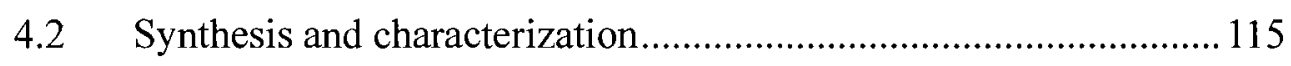

4.3 Absorption and photoluminescent properties of dpb ligand polymers 118

4.4 Absorption and photoluminescent properties of ligand polymers

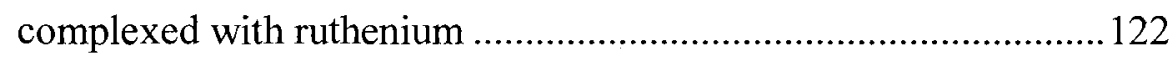

4.5 Absorption and photoluminescent properties of ligand polymers

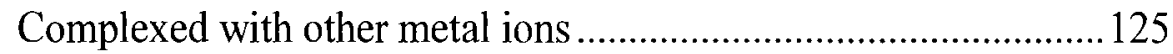

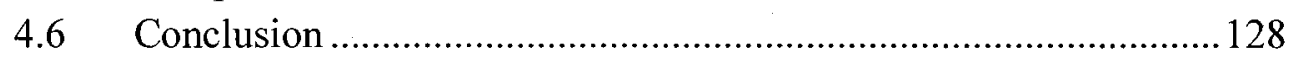

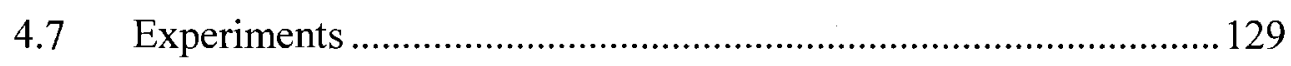

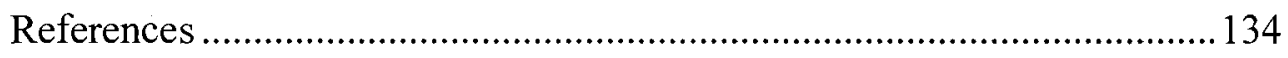

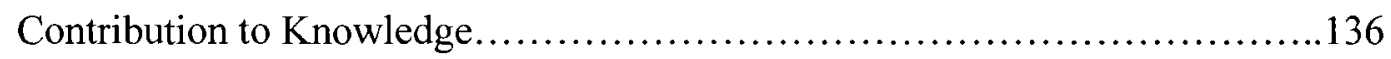

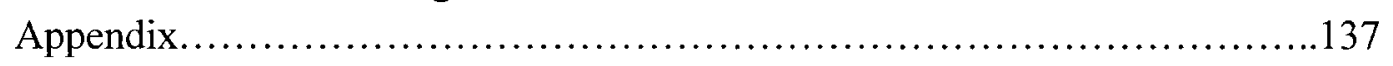




\section{List of Figures}

Figure 1.1. Generic structure of planar bis-dithiolene complexes and complexes of dialkyl-substituted imidazolidine-2,4,5-trithiones. 3

Figure 1.2. Structure of Mo complex and its electronic spectra in the oxidation states: $\mathrm{Mo}^{\mathrm{V}}-\mathrm{Mo}^{\mathrm{V}}(\mathrm{n}=0)(\mathrm{i}), \mathrm{Mo}^{\mathrm{V}}-\mathrm{Mo}^{\mathrm{Vl}}(\mathrm{n}=1)$ (ii), $\mathrm{Mo}^{\mathrm{VI}}-\mathrm{Mo}^{\mathrm{VI}}(\mathrm{n}=2)$ (iii) (adopted from Ref. 10b)

Figure 1.3. Ligand-centred redox species and the electrochromic behavior (adopted from Ref. 13)

Figure 1.4. Structure of the dinuclear ruthenium complex polymer and its absorption spectra in three different oxidation states (adopted from Ref. 23)

Figure 1.5. Structure of ErQ and its PL at $300 \mathrm{~K}$ (excited using the $457 \mathrm{~nm}$ line from an argon-ion laser) and EL obtained from an ITO/TPD $(500 \AA) / \operatorname{ErQ}(600 \AA) / \mathrm{Al}$ OLED. (adopted from Ref. 28a).

Fgiure 1.6. Structures of MEH-PPV, PPP-OR11 and Ln(TPP)acac. 17

Figure 1.7. Structure of Ln(TPP)Tp and EL spectra of (a) 5, (b) 10, and (c) 15 mol\% Yb(TPP)Tp in PPP-OR11 at $8 \mathrm{~V}$ (adopted from Ref. 28n).

Figure 1.8. Structures of Lissamine-functionalized organic neodymium complex (Ls. $\mathrm{Nd}^{3+}$ ) and F8BT.

Figure 1.9. Structures of $\mathrm{Nd}(\mathrm{DBM})_{3}(\mathrm{TPPO})_{2}$ and $\mathrm{Ln}(\mathrm{DBM})_{3}(\mathrm{dpphen})(\mathrm{Ln}=$ $\mathrm{Nd}, \mathrm{Yb}, \mathrm{Er}, \mathrm{Pr}, \mathrm{Ho}$ ).

Figure 1.10. Terthiophene and quinquethiophene acetate oligomers for NIR Er-centered luminescence.

Figure 1.11. Structures of polymers I-IV and their EL spectra (adopted from Ref. 29d).

Figure 1.12. Structures of NIR electroluminescent polymers.

Figure 1.13. Structures of ruthenium- and rhenium-containing polymers based on oxadiazole-substituted bpy and phen ligands (adopted from Ref. 48)....

Figure 1.14. Structure of the polymer (P1) and a photograph showing emission of light from P1 and its metal complexes in THF (adopted from Ref.53). 
Figure 1.15. Examples of ruthenium- or rhenium-containing polyimides, polyesters, and polyamides.

Figure 1.16. Structures of PPV incorporated with pendant ruthenium complexes (adopted from Ref. 59). 36

Figure 1.17. EL spectra of ruthenium complex polymers (adopted from Ref. 23).

Figure 2.1. General structure of dinuclear DCH-Ru complexes

Figure 2.2. Mass spectrum of complex 2.1. .52

Figure 2.3. $\quad \mathrm{CV}$ of complex 2.1 (a) in $0.1 \mathrm{M} \mathrm{NEt}_{4} \mathrm{ClO}_{4} / \mathrm{CH}_{3} \mathrm{CN}$ and (b) as a film on indium tin oxide coated glass, at a scan rate of $100 \mathrm{mVs}^{-1}$.......................53

Figure 2.4. Hammett parameter versus $\mathrm{E}_{1 / 2}$ for complexes 2.1-2.4 ................55

Figure 2.5. UV-vis-NIR spectra of complex 2.4 in three oxidation states.......55

Figure 2.6. Absorption spectra of complexes in the $\mathrm{Ru}^{\text {III }} / \mathrm{Ru}^{\text {III }}$ state in $0.1 \mathrm{M}$ $\mathrm{NEt}_{4} \mathrm{ClO}_{4} / \mathrm{CH}_{3} \mathrm{CN}$ obtained using an optically transparent thin-layer electrochemical cell.

Figure 2.7. Absorbance $(1150 \mathrm{~nm})$ of complex $2.1\left(1 \times 10^{-4} \mathrm{M}\right.$ in 1:1 acetonitrile: Tris buffer) in the $\mathrm{Ru}^{\mathrm{II}} / \mathrm{Ru}^{\mathrm{II}}$ state by oxidization with different concentrations of $\mathrm{H}_{2} \mathrm{O}_{2}$ recorded at different time. .58

Figure 2.8. Normalized absorbance $(1150 \mathrm{~nm})$, recorded in real time, of a film containing complex 2.1 in the $\mathrm{Ru}^{\mathrm{II}} / \mathrm{Ru}^{\mathrm{II}}$ state oxidized with $\mathrm{H}_{2} \mathrm{O}_{2}(0.3 \mathrm{M})$ in TRIS buffer solution. Film was reduced electrochemically $(-0.5 \mathrm{~V})$.

Figure 2.9. Mechanism of DCH-Ru complex controlled PL of dye. 61

Figure 2.10. Structure of complex 2.1-IR125, PL spectrum of IR125 in methanol $\left(10^{-5} \mathrm{M}\right)$ and absorption spectra of complex $2.1\left(\mathrm{Ru}^{\mathrm{Il}} / \mathrm{Ru}^{\mathrm{II}}\right)$ and $\left(\mathrm{Ru}^{\mathrm{II}} / \mathrm{Ru}^{\mathrm{III}}\right)$ in $\mathrm{CH}_{3} \mathrm{CN}\left(10^{-5} \mathrm{M}\right)$.......

Figure 2.11. Structure of complex 2.4-SRB, PL spectrum of SRB in methanol $\left(10^{-5} \mathrm{M}\right)$ and absorption spectra of complex $2.4\left(\mathrm{Ru}^{\mathrm{II}} / \mathrm{Ru}^{\mathrm{Il}}\right)$ and $\left(\mathrm{Ru}^{\mathrm{II}} / \mathrm{Ru}^{\mathrm{III}}\right)$ in $\mathrm{CH}_{3} \mathrm{CN}\left(10^{-5} \mathrm{M}\right)$..

Figure 2.12. PL quenching of IR125 by complex $2.1\left(\mathrm{Ru}^{\mathrm{II}} / \mathrm{Ru}{ }^{\mathrm{II}}\right)$ in methanol. . 64

Figure 2.13. PL quenching of IR 125 by complex $2.1\left(\mathrm{Ru}^{\mathrm{II}} / \mathrm{Ru}{ }^{\mathrm{III}}\right)$ in methanol. 65 
Figure 2.14. PL quenching of IR125 with the different content of complex 2.1 in the $\mathrm{Ru}^{\mathrm{II}} / \mathrm{Ru}{ }^{\mathrm{II}}$ and $\mathrm{Ru}{ }^{\mathrm{II}} / \mathrm{Ru}{ }^{\mathrm{III}}$ states.

Figure 2.15. $\mathrm{CV}$ graphs of complex 2.1 in $0.1 \mathrm{M} \mathrm{NEt}_{4} \mathrm{ClO}_{4} / \mathrm{CH}_{3} \mathrm{CN}$, IR125 in $0.1 \mathrm{M} \mathrm{NEt}_{4} \mathrm{ClO}_{4} /$ methanol and complex 2.1-IR125 in $0.1 \mathrm{M} \mathrm{NEt}_{4} \mathrm{ClO}_{4} / \mathrm{DMF}$ at a scan rate of $100 \mathrm{mVs}^{-1}$.

Figure 2.16. Absorption changes of complex 2.1-IR125 in 0.1 $\mathrm{M} \mathrm{NEt}_{4} \mathrm{ClO}_{4} /$ DMF by applying different potential with an OTTLE cell. 68

Figure 2.17. PL quenching of SRB by complex $2.4\left(\mathrm{Ru}^{\mathrm{II}} / \mathrm{Ru}^{\mathrm{II}}\right)$ in methanol. ...69

Figure 2.18. PL quenching of SRB by complex $2.4\left(\mathrm{Ru}^{\mathrm{II}} / \mathrm{Ru}^{\mathrm{III}}\right)$ in methanol....69

Figure 2.19. PL quenching of SRB with the different content of complex 2.4 in the $\mathrm{Ru}^{\mathrm{II}} / \mathrm{Ru}^{\mathrm{II}}$ and $\mathrm{Ru}^{\mathrm{II}} / \mathrm{Ru}{ }^{\mathrm{III}}$ states. 70

Figure 2.20. $\mathrm{CV}$ of complex 2.4 and complex 2.4-SRB in $0.1 \mathrm{M}$ $\mathrm{NEt}_{4} \mathrm{ClO}_{4} / \mathrm{DMF}$ at a scan rate of $100 \mathrm{mVs}^{-1}$.

Figure 2.21. $\mathrm{CV}$ of complex 2.4-SRB film in $0.1 \mathrm{M} \mathrm{NEt}_{4} \mathrm{ClO}_{4} / \mathrm{CH}_{3} \mathrm{CN}$ at a scan rate of $100 \mathrm{mV} / \mathrm{s}$ (20 cycles).

Figure 2.22. Absorption spectra of complex 2.4-SRB in $0.1 \mathrm{M}$ $\mathrm{NEt}_{4} \mathrm{ClO}_{4} / \mathrm{CH}_{3} \mathrm{CN}$ using an OTTLE cell. 72

Figure 2.23. Absorption spectra of a film containing complex 2.4-SRB (15 $w t \%)$.

Figure 2.24. PL intensity $(590 \mathrm{~nm})$ of films containing different amounts of complex 2.4-SRB in the $\mathrm{Ru}^{\mathrm{II}} / \mathrm{Ru}^{\mathrm{III}}$ state after being oxidized electrochemically..73

Figure 2.25. Schematic diagram of OTTLE cell (front view). .76

Figure 2.26. Set-up of spectroelectrochemcial and switching experiments.......77

Figure 3.1. Device structure of LEC ......................................................83

Figure 3.2. Structures of ruthenium complexes 3.1-3.13......................... 86

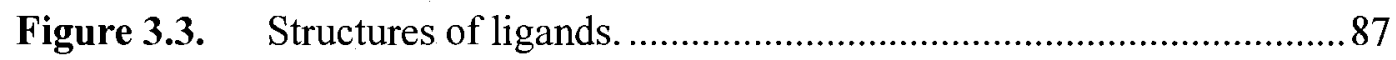

Figure 3.4. Mass spectrum of complex 3.13 ......................................... 90

Figure 3.5. Absorption spectra of complexes 3.1-3.13 in $\mathrm{CH}_{3} \mathrm{CN}\left(10^{-5} \mathrm{M}\right) \ldots . .92$ 
Figure 3.6. $\quad \mathrm{PL}$ spectra of complexes 3.1-3.11 in $\mathrm{CH}_{3} \mathrm{CN}\left(10^{-5} \mathrm{M}\right)$. .92

Figure 3.7. $\mathrm{CV}$ of complexes 3.6 and 3.9 in $0.1 \mathrm{M} \mathrm{NEt}_{4} \mathrm{ClO}_{4} / \mathrm{CH}_{3} \mathrm{CN}$ at a scan rate of $100 \mathrm{mVs}^{-1}$.

Figure 3.8. The LUMO and HOMO energy levels of complexes 3.1-3.13 ....94

Figure 3.9. EL spectra of the LEC devices based on ruthenium complexes....98

Figure 3.10. The $L-V-t$ curves of the devices (a) complex 3.1 (b) complex $\mathbf{3 . 2}$

(c) complex 3.3 (d) complex 3.5 (e) complex 3.6 (f) complex 3.7 (g) complex 3.13

(h) complex 3.9.

Figure 4.1. Structure of dpb.

Figure 4.2. ${ }^{1} \mathrm{H}$ NMR spectra of (a) PDPB in $\mathrm{d}_{6}$-DMSO and (b) PFO-DPB in $\mathrm{CDCl}_{3}$. The peaks with the ${ }^{*}$ are due to solvent impurities.

Figure 4.3. Absorption and PL spectra of dpb in THF, PDPB in DMF and PFO-DPB in THF $\left(10^{-5} \mathrm{M}\right)$.

Figure 4.4. Changes in (a) UV-vis absorption and (b) PL spectra of PFO-DPB (4.2 $\times 10^{-5} \mathrm{M}$ (repeating unit)) in THF at various concentrations of trichloroacetic acid (TCA): $[\mathrm{TCA}]=0,5.5 \times 10^{-5}, 3.6 \times 10^{-4}, 5.8 \times 10^{-4}, 1.1 \times 10^{-3}, 1.8 \times 10^{-3}, 3.2$ $\times 10^{-3}, 6.7 \times 10^{-3}, 1.5 \times 10^{-2}, 3.2 \times 10^{-2}, 4.8 \times 10^{-2} \mathrm{M}$. Arrows indicate the direction of the change from low to high concentration.

Figure 4.5. Changes in (a) UV-vis absorption and (b) PL spectra of PDPB (6.3 $\times 10^{-5} \mathrm{M}$ (repeating unit)) in $\mathrm{CH}_{3} \mathrm{CN}$ at various concentrations of trichloroacetic acid (TCA): $\left[\right.$ TCA] $=0,1.4 \times 10^{-4}, 3.2 \times 10^{-4}, 9.3 \times 10^{-4}, 2.0 \times 10^{-3}, 3.9 \times 10^{-3}, 9.2$ $\times 10^{-3}, 2.5 \times 10^{-2}, 5.8 \times 10^{-2} \mathrm{M}$. Arrows indicate the direction of the change from low to high concentration.

Figure 4.6. Absorption spectra of PFO-DPB and PFO-DPB-Ru1-3 in solution.

Figure 4.7. PL spectra of PFO-DPB and PFO-DPB-Ru1 in chloroform $(5.0 \times$ $\left.10^{-5} \mathrm{M}\right)$ (excitation at $460 \mathrm{~nm}$ ).

Figure 4.8. PL intensity changes of (a) PDPB $\left(5.1 \times 10^{-5} \mathrm{M}\right)$ in DMF-methanol (10:1) and (b) PFO-DPB $\left(3.5 \times 10^{-5} \mathrm{M}\right)$ in THF-methanol (10:1) after addition of various metal ions at the molar ratio of 40:1 (metal ion: repeating unit of the polymers) $\left(\mathrm{I}_{0}=\mathrm{PL}\right.$ intensity of pure polymer solution. $\mathrm{I}=\mathrm{PL}$ intensity of the polymer solution after chelating with metal ions). 
Figure 4.9. Changes in (a) UV-vis absorption and (b) PL spectra of PFO-DPB $\left(3.5 \times 10^{-5}\right)$ in THF-methanol $(10: 1)$ at various concentrations of $\mathrm{PdCl}_{2}$. $\left[\mathrm{PdCl}_{2}\right]=$ $0,4.52 \times 10^{-5}, 2.15 \times 10^{-4}, 1.40 \times 10^{-3} \mathrm{M}$. Arrows indicate the direction of the change from low to high concentration. 126

Figure 4.10. Changes in PL intensity of PFO-DPB and PDPB by titration with $\mathrm{Ag}^{+}$. Concentration of polymer solution: $5.0 \times 10^{-5} \mathrm{M}$...................................... 127 


\section{List of Shemes}

Scheme 1.1. Structures of $\mathrm{L}^{21}-\mathrm{L}^{23}$ and ligand-based redox activity of (a) the CAT-SQ-Q series; (b) $\left[\mathrm{L}^{21}\right]^{\mathrm{n}-}(\mathrm{n}=4-0)$

Scheme 1.2. Synthesis of the ruthenium complex polymers (adopted from Ref.45).

Scheme 1.3. PPVs incorporated with ruthenium or rhenium dipyridophenazine complexes (adopted from Ref.47).

Scheme 1.4. Synthesis and metal complexation of bpy-containing poly(benzobisoxazole) and poly(benzobisthiazole) (adopted from Ref. 54).........3 34

Scheme 2.1. Synthesis of complexes 2.1-2.4 and corresponding ligands.........51

Scheme 2.2. Detection of $\mathrm{H}_{2} \mathrm{O}_{2}$. Cuvettes shown are acetonitrile solutions of the complex in their respective oxidation states.

Scheme 3.1. Emission mechanism of LEC based on ruthenium complex.

Scheme 3.2. Synthesis of ruthenium complexes.

Scheme 4.1. Synthetic routes to the monomer 4.2 and polymers. 116

Scheme 4.2. Synthetic routes to the ruthenium complex polymer PFO-DPB-Ru. 


\section{List of Tables}

Table 1.1. Principal low-energy absorption maxima of dinuclear complexes $\left[\left\{\mathrm{Mo}\left(\mathrm{Tp}^{*}\right)(\mathrm{O}) \mathrm{Cl}\right\}_{2}(\mathrm{~L})\right]^{\mathrm{n}+}$ in their forms $(\mathrm{n}=1,2) \ldots$

Table 1.2. Examples of mixed-valence dinuclear ruthenium complexes showing

NIR electrochromism.

Table 1.3. Structures of organic ionic dyes and their EL emission peaks based on the LEDs.

Table 2.1. Electrochemical data, Hammett substituent parameters and MMCT band energies for DCH-Ru complexes

Table 3.1. The optical properties, electrochemical data and energy levels of complexes.

Table 3.2. Electroluminescent properties of complexes. 100

Table 4.1. Characterization of ligand polymers.

Table 4.2. Absorption and photoluminescent data of $\mathrm{dpb}$ and polymers. .120

Table 4.3. Ruthenium content in PFO-DPB-Ru. 


\title{
List of Symbols and Abbreviations
}

\author{
$\sigma^{*} \quad$ Hammett parameters \\ $\eta_{\mathrm{ph}} \quad$ External quantum efficiency \\ $\eta_{\text {power }} \quad$ Power conversion efficiency \\ Mn Number-average molecular weight \\ Td Decomposition temperature \\ acac Acetylacetone \\ $\mathrm{Alq}_{3} \quad$ Aluminum tris(8-hydroxyquinolinate) \\ BL Bridging ligand \\ bpy 2,2-Bipyridine \\ DCH 1,2-Dicarbonylhydrazine \\ DCH-Ru Dinuclear ruthenium complexes with DCH bridging ligands \\ dpb 2,3-Bis(2-pyridyl)benzoquinoxaline \\ EL Electroluminescence \\ ErQ Erbium tris(8-hydroxy-quinoline) \\ ET Energy transfer \\ FWHM Full width at half-maximum \\ ICT Intromolecular charge transfer \\ ITO Indium tin oxide \\ LMCT Ligand-to-metal charge transfer \\ MLCT Metal-to-ligand charge transfter
}


MMCT Metal-to-metal charge transfer

OLED Organic light-emitting diodes

OTTLE Optically transparent thin-layer electrochemical cell

PBIm-H 2-(2-Pyridyl)benzimidazole

phen 1,10-Phenanthroline

PHPI 2-Pyridin-2-yl-1H-phenanthro[9,10-d] imidazole

PPV Poly(phenylene-vinylene)

TGA Thermogravimetric analysis 


\section{Chapter 1 Introduction to Near Infrared Organic Materials}

The near-infrared (NIR) light falls in the infrared region of the electromagnetic spectrum and typically covers the spectrum from 750 to $2500 \mathrm{~nm}$ (120 to $400 \mathrm{THz}$ ). Physical processes that are relevant for this range are similar to those for visible light. Visible light (and near-infrared light) is typically absorbed and emitted by electrons in molecules and atoms that move from one energy level to another.

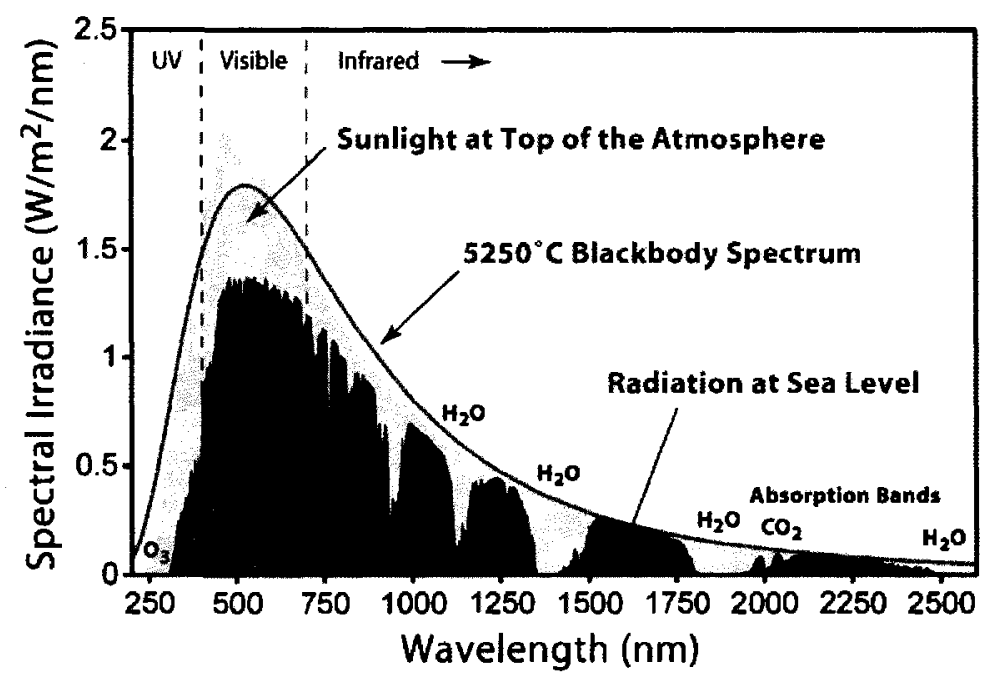

NIR optoelectronic materials have attracted much recent interest ${ }^{1}$ because of the considerable technological importance of this region of the spectrum. NIR radiation finds use in many applications as diverse as optical data storage, ${ }^{2}$ in medicine, where photodynamic therapy exploits the relative transparency of living tissue to NIR radiation around $800 \mathrm{~nm},{ }^{3}$ and in telecommunications, where optical signal transmission through silica fibers exploits the "windows of transparency" in 
the 1300-1550 $\mathrm{nm}$ region. NIR-absorbing or reflecting materials are used in low-emission windows for energy saving in buildings. Effective light-harvesting compounds for use in solar cells need to capture NIR as well as visible light. ${ }^{4}$ In addition, NIR technology is also used extensively for military applications such as target acquisition, surveillance, night vision, homing and tracking. ${ }^{5}$ The research background is summarized as follows.

\subsection{NIR redox-active metal complexes}

Many compounds with strong NIR absorptions have been investigated for optical memory media applications. ${ }^{6}$ The majority of these compounds are $\pi$-conjugated or delocalized but not redox active. A minority however are based on transition-metal complexes that generally have the redox activity necessary for electrochromic behavior. These NIR redox-active metal complexes are discussed in the following sections.

\subsubsection{Planar dithiolene complexes of $\mathrm{Ni}, \mathrm{Pd}$ and $\mathrm{Pt}$}

One of the earliest series of metal complexes that showed strong, redox-dependent NIR absorptions is the well-studied set of square-planar bis-dithiolene complexes of $\mathrm{Ni}, \mathrm{Pd}$ and Pt (Figure 1.1). Extensive delocalization between metal and ligand orbitals in these 'non-innocent' systems means that assignment of oxidation states is problematic, but it does result in intense electronic transitions. These complexes have two reversible redox processes 
connecting the neutral, monoanionic and dianionic species.

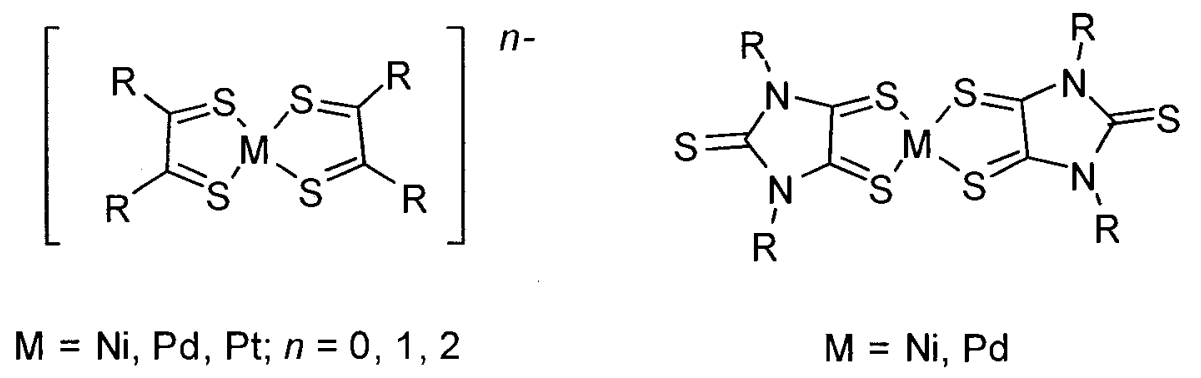

Figure 1.1. Generic structure of planar bis-dithiolene complexes and complexes of dialkyl-substituted imidazolidine-2,4,5-trithiones.

The structures and redox properties of these complexes have been extensively studied and reviewed. ${ }^{7}$ Neutral and monoanionic forms exhibit intense NIR transitions. The positions of the NIR absorptions are highly sensitive to the substituents on the dithiolene ligands. A large number of substituted dithiolene ligands have been prepared and used to prepare complexes of $\mathrm{Ni}, \mathrm{Pd}$ and $\mathrm{Pt}$ which show comparable electrochromic properties with absorption maxima at wavelengths up to ca. $1400 \mathrm{~nm}$ and extinction coefficients up to ca. $40000 \mathrm{dm}^{3}$ $\mathrm{mol}^{-1} \mathrm{~cm}^{-1}$

The main application of the strong NIR absorbance of these complexes, pioneered by Müller-Westerhoff and co-workers, ${ }^{8}$ is for use in the neutral state as dyes to induce Q-switching of NIR lasers such as the Nd-YAG (1064 nm), iodine $(1310 \mathrm{~nm})$ and erbium $(1540 \mathrm{~nm})$ lasers. This relies on a combination of very high absorbance at the laser wavelengths, an appropriate excited-state lifetime following excitation, and high thermal and photochemical stability. The use of a range of metal dithiolene complexes in this respect have been reviewed. ${ }^{7 b, 8}$ The 
strong NIR absorptions of these complexes have continued to attract attention since these reviews appeared. A new series of neutral, planar dithiolenes of $\mathrm{Ni}$ and Pd has been prepared based on the ligands $\left[\mathrm{R}_{2} \text { timdt }\right]^{-}$which contain the dialkyl-substituted imidazolidine-2,4,5-trithione core (Figure 1.1). ${ }^{9}$ In these ligands the peripheral ring system ensures that the electron-donating $N$ substituents are coplanar with the dithiolene unit, maximizing the electronic effect. This shifts the NIR absorptions of the $\left[\mathrm{M}\left(\mathrm{R}_{2} \text { timdt }\right)_{2}\right]$ complexes to lower energy than found in the 'parent' dithiolene complexes. The result is that the NIR absorption maximum occurs at around $1000 \mathrm{~nm}$ and has a remarkably high extinction coefficient (up to $80000 \mathrm{dm}^{3} \mathrm{~mol}^{-1} \mathrm{~cm}^{-1}$ ). The high thermal and photochemical stabilities of these complexes make them excellent candidates for Q-switching of the $1064 \mathrm{~nm}$ Nd-YAG laser. In addition, one-electron reduction to the monoanionic species $\left[\mathrm{M}\left(\mathrm{R}_{2} \text { timdt }\right)_{2}\right]^{-}$results in a shift of the NIR absorption maximum to $c a$. $1400 \mathrm{~nm}$, indicating possible exploitation of their electrochromism. ${ }^{9 \mathrm{~g}}$

\subsubsection{Tris(pyrazolyl)borato-molybdenum complexes}

McCleverty, Ward and co-workers prepared and examined an extensive series of mononuclear and dinuclear complexes containing the oxo- $\mathrm{Mo}^{\mathrm{v}}$ core unit $\left[\mathrm{Mo}\left(\mathrm{Tp}^{*}\right)(\mathrm{O}) \mathrm{Cl}(\mathrm{OAr})\right]\left(\mathrm{Ar}=\right.$ phenyl or naphthyl ring system, $\mathrm{Tp}^{*}=$ hydrotris(3,5-dimethylpyrazolyl)borate). ${ }^{10}$ Mononuclear complexes of this type undergo reversible $\mathrm{Mo}^{\mathrm{IV}}-\mathrm{Mo}^{\mathrm{V}}$ and $\mathrm{Mo}^{\mathrm{V}}-\mathrm{Mo}^{\mathrm{VI}}$ redox processes with all three 
oxidation states accessible at modest potentials, while reduction to the $\mathrm{Mo}^{\mathrm{IV}}$ state results in the appearance of a low-energy phenolate-(or naphtholate)-to-Mo ${ }^{\mathrm{VI}}$ charge transfer process. ${ }^{10 a, 10 b}$

In mononuclear complexes these transitions are at the low-energy end of the visible region and of moderate intensity. However in many dinuclear complexes of the type $\left[\left\{\mathrm{Mo}\left(\mathrm{Tp}^{*}\right)(\mathrm{O}) \mathrm{Cl}\right\}_{2}\left(\mu-\mathrm{OC}_{6} \mathrm{H}_{4} \mathrm{EC}_{6} \mathrm{H}_{4} \mathrm{O}\right)\right]$, in which two oxo-Mo(V) fragments are connected by a bisphenolate bridging ligand in which a conjugated spacer ' $E$ ' separates the two phenyl rings, the NIR electrochromism is much stronger. In these complexes an electronic interaction between the two metals results in a separation of the two $\mathrm{Mo}^{\mathrm{V}}-\mathrm{Mo}^{\mathrm{VI}}$ couples, such that the complexes can be oxidized from the $\mathrm{Mo}^{\mathrm{V}}-\mathrm{Mo}^{\mathrm{V}}$ state to $\mathrm{Mo}^{\mathrm{V}}-\mathrm{Mo}^{\mathrm{VI}}$ and then $\mathrm{Mo}^{\mathrm{VI}}$ $\mathrm{Mo}^{\mathrm{VI}}$ in two distinct steps. The important point here is that in the oxidized forms, containing one or two $\mathrm{Mo}^{\mathrm{VI}}$ centers, the ligand-to-metal charge transfer (LMCT) transitions are at lower energy and of much higher intensity than in the mononuclear complexes (see a representative example in Figure 1.2). Depending on the nature of the group $\mathrm{E}$ in the bridging ligand, the absorption maxima can span the range $800-1500 \mathrm{~nm}$. (Table 1.1) 

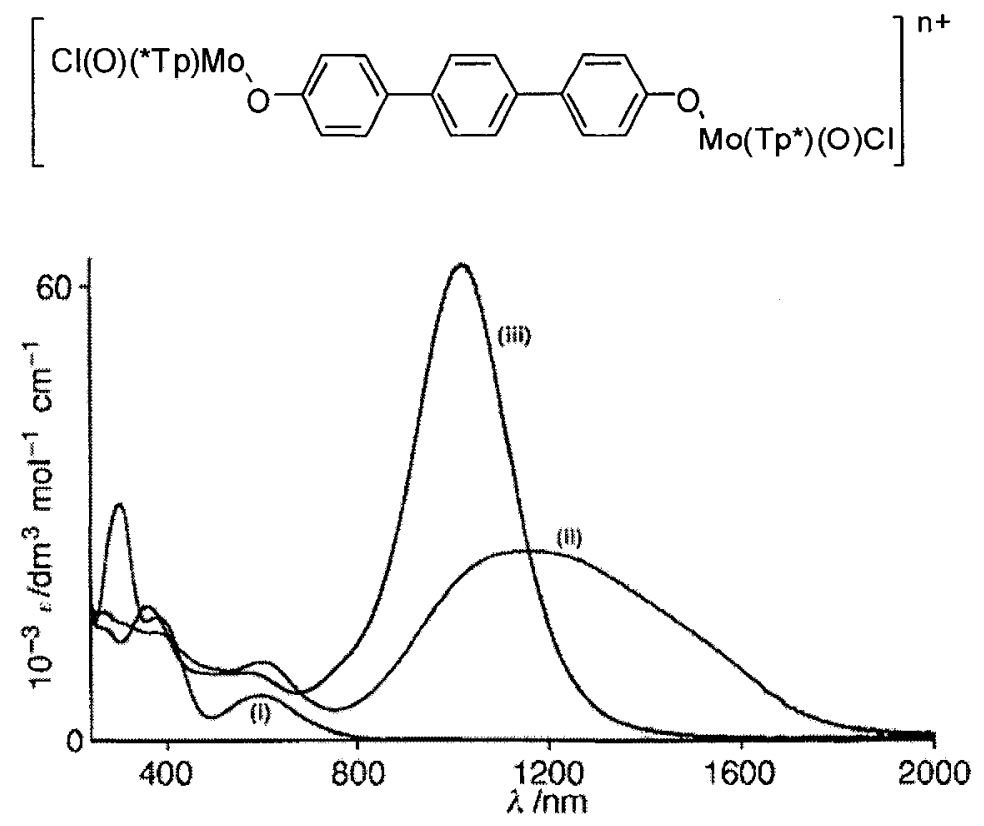

Figure 1.2. Structure of Mo complex and its electronic spectra in the oxidation states: $\mathrm{Mo}^{\mathrm{V}}-\mathrm{Mo}^{\mathrm{V}}(\mathrm{n}=0)(\mathrm{i}), \mathrm{Mo}^{\mathrm{V}}-\mathrm{Mo}^{\mathrm{VI}}(\mathrm{n}=1)$ (ii), $\mathrm{Mo}^{\mathrm{VI}}-\mathrm{Mo}^{\mathrm{VI}}(\mathrm{n}=2)$ (iii) (adopted from Ref. 10b).

Some nitrosyl-Mo ${ }^{\mathrm{I}}$ complexes of the form $\left[\mathrm{Mo}\left(\mathrm{Tp}^{*}\right)(\mathrm{NO}) \mathrm{Cl}(\mathrm{py}-\mathrm{R})\right]$ (where py- $\mathrm{R}$ is a substituted pyridine) also undergo moderate NIR electrochromism on reversible reduction to the $\mathrm{Mo}^{0}$ state. In these complexes reduction of the metal center results in appearance of a $\mathrm{Mo}^{0} \rightarrow \operatorname{py}\left(\pi^{*}\right)$ metal-to-ligand charge transfer (MLCT) transition at the red end of the spectrum. However, when the pyridyl ligand contains an electron-withdrawing substituent meta to the $\mathrm{N}$ atom, an additional MLCT transition at much longer wavelength develops. 
Table 1.1. Principal low-energy absorption maxima of dinuclear complexes $\left[\left\{\mathrm{Mo}\left(\mathrm{Tp}^{*}\right)(\mathrm{O}) \mathrm{Cl}\right\}_{2}(\mathrm{~L})\right]^{\mathrm{n}+}$ in their forms $(\mathrm{n}=1,2)$.

\begin{tabular}{|c|c|c|}
\hline \multirow[t]{2}{*}{ Bridging Ligand (L) } & \multicolumn{2}{|c|}{$\lambda_{\max }(\mathrm{nm})$} \\
\hline & $\mathrm{Mo}(\mathrm{V})-\mathrm{Mo}(\mathrm{VI})$ & $\operatorname{Mo}(\mathrm{VI})-\mathrm{Mo}(\mathrm{VI})$ \\
\hline & 1096 & 1017 \\
\hline & 1245 & 832 \\
\hline & 1131 & 1016 \\
\hline & 1197 & 684 \\
\hline & 1360 & Not stable \\
\hline & 900 & 900 \\
\hline & 1554 & 978 \\
\hline
\end{tabular}

\subsubsection{Ruthenium dioxolene complexes}

Lever and co-workers described in 1986 the mononuclear complex $\left[\mathrm{Ru}(\text { bipy })_{2}(\mathrm{CAT})\right]$, which has no NIR absorption. It undergoes however two reversible oxidations which are ligand-centred CAT-SQ and SQ-Q couples (where CAT, SQ and $\mathrm{Q}$ are catecholate, 1,2-benzosemiquinone monoanion, and 1,2-benzoquinone, respectively; Scheme 1.1). ${ }^{11}$ In the two oxidized forms the presence of a 'hole' in the dioxolene ligand results in the appearance of $\mathrm{Ru}^{\mathrm{II}} \rightarrow \mathrm{SQ}$ and $\mathrm{Ru}^{\mathrm{II}} \rightarrow \mathrm{Q}$ MLCT transitions, the former at $890 \mathrm{~nm}$ and the latter at $640 \mathrm{~nm}$. 
The CAT-SQ and SQ-Q couples accordingly result in modest NIR electrochromic behavior.

When two or more of these chromophores are linked by a conjugated bridging ligand, as in $\left[\left\{\mathrm{Ru}(\text { bipy })_{2}\right\}_{2}\left(\mu-\mathrm{L}^{21}\right)\right]^{n+}(n=0-4)$, which exhibits a five-membered redox chain, with reversible conversions between the fully reduced (bis-catecholate) and fully oxidized (bis-quinone) states all centred on the bridging ligand (Scheme 1.1). In the state $n=2$, the NIR absorption is at $1080 \mathrm{~nm}$, which disappears in the fully reduced form and moves into the visible region in the fully oxidized form. ${ }^{12}$ Likewise, the trinuclear complex $\left[\left\{\mathrm{Ru}(\text { bipy })_{2}\right\}_{3}\left(\mu-\mathrm{L}^{22}\right)\right]^{n+}(n=3-6)$ exists in four stable redox states based on redox interconversions of the bridging ligand (from SQ-SQ-SQ to Q-Q-Q; Figure 1.3). ${ }^{13}$ Thus the complexes are electropolychromic, with a large number of stable oxidation states accessible in which the intense NIR MLCT transitions involving the oxidized forms of the bridging ligand are redox-dependent. In this example, the NIR transitions vary in wavelength between 759 and $1170 \mathrm{~nm}$ over these four oxidation states. Other polydioxolene bridging ligands such as $\left[\mathrm{L}^{23}\right]^{3-}$ have been investigated and their $\left\{\mathrm{Ru}(\text { bipy })_{2}\right\}^{2+}$ complexes show comparable electropolychromic behaviour in the NIR region. ${ }^{14}$ 
<smiles>Oc1ccc(-c2ccc(O)c(O)c2)cc1O</smiles>
$\mathrm{H}_{4} \mathrm{~L}^{21}$<smiles>Oc1cc2c(cc1O)c1ccc(O)c(O)c1c1cc(O)c(O)cc21</smiles>

$\mathrm{H}_{6} \mathrm{~L}^{22}$<smiles>O=C1CC2Oc3cc(O)c(O)cc3C(c3ccccc3)=C2C=C1O</smiles>

$\mathrm{H}_{3} \mathrm{~L}^{23}$

(a)
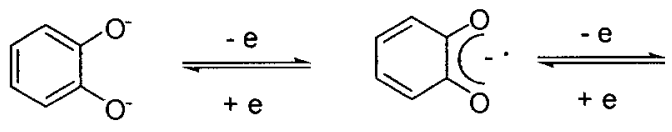<smiles>O=C1C=CC=CC1=O</smiles>

$(\text { CAT })^{2}$

$(\mathrm{SQ})^{-}$

Q

(b)

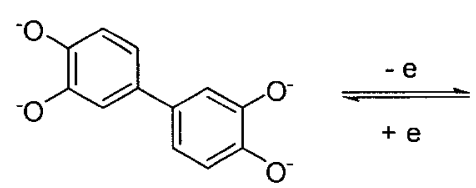

CAT-CAT

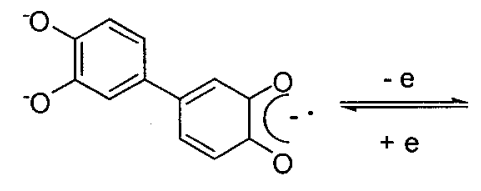

CAT-SQ<smiles>[O]C1=CC(=C2C=CC(=O)C(O)=C2)C=CC1=O</smiles>
SQ-SQ

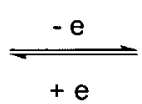<smiles>O=C1C=CC(C2=CC(=O)C(=O)C=C2)=CC1=O</smiles>

$S Q-Q$

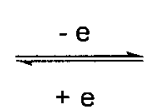

$\mathrm{Q}-\mathrm{Q}$

Scheme 1.1. Structures of $\mathrm{L}^{21}-\mathrm{L}^{23}$ and ligand-based redox activity of (a) the CAT-SQ-Q series; (b) $\left[\mathrm{L}^{21}\right]^{\mathrm{n}-}(\mathrm{n}=4-0)$.

The impressive NIR electrochromic behaviour of these ruthenium dioxolene complexes has led to some of them being incorporated into 'electrochromic windows' in which the complex units are adsorbed onto a nanocrystalline $\mathrm{Sb}$-doped $\mathrm{SnO}_{2}$ surface via carboxylate anchors on the terminal bipy ligands. ${ }^{15}$ Redox cycling of the catecholate-semiquinone couple results in fast electrochromic switching of the film at $940 \mathrm{~nm}$ as the $\mathrm{Ru}^{\mathrm{II}} \rightarrow \mathrm{SQ}$ MLCT transition appears and disappears. 

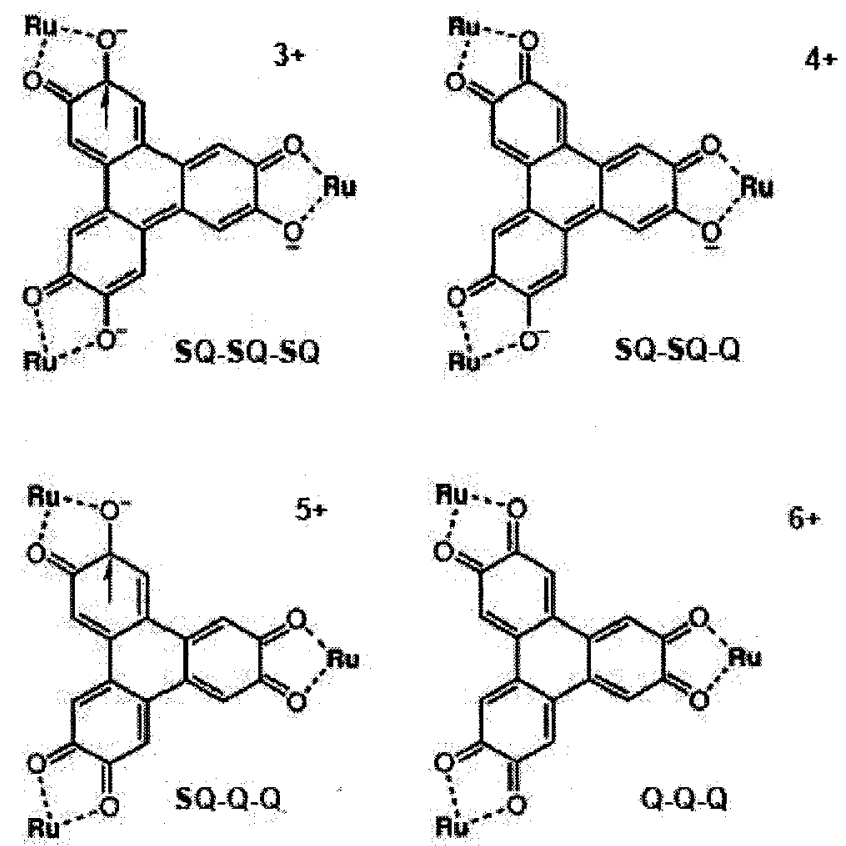

$\mathbf{R u}=\left\{\mathrm{Ru}(\mathrm{bipy})_{2}\right\}^{2+}$

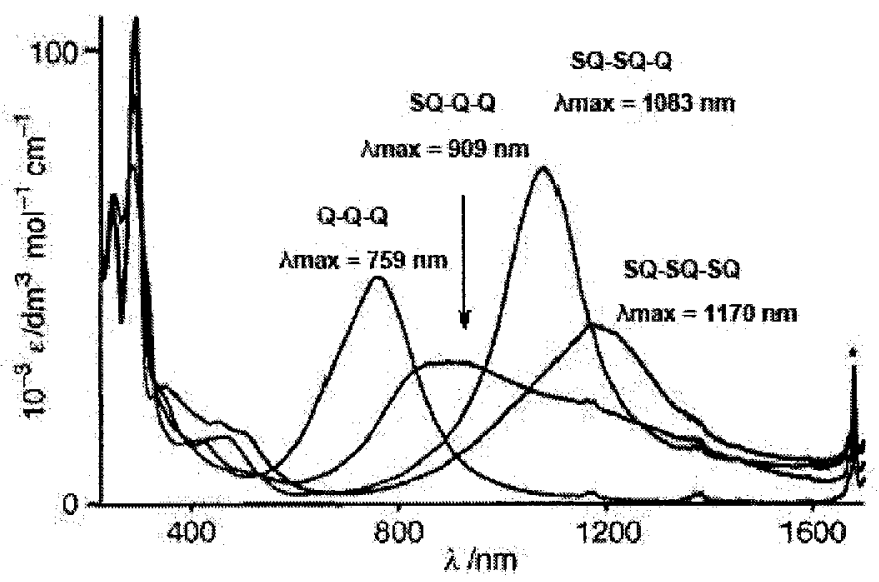

Figure 1.3. Ligand-centred redox species and the electrochromic behavior (adopted from Ref. 13).

\subsubsection{Mixed-valence dinuclear ruthenium complexes}

It has been known since the discovery of the Creut $^{16}$ that dinuclear mixed-valence complexes based principally on ruthenium-ammine or ruthenium-polypyridine components generally show a $\mathrm{Ru}^{\mathrm{II}} \rightarrow \mathrm{Ru}^{\mathrm{III}}$ intervalence charge-transfer transition (IVCT). Research on polynuclear ruthenium complexes 
with mixed-valence configurations has been an interesting topic for the study of electron-transfer processes, ${ }^{17}$ the design of components for molecular electronics, ${ }^{18}$ and their relevance to biochemically important system. ${ }^{19}$ The work by Kaim et al. shows that dinuclear ruthenium complexes with 1,2-dicarbonylhydrazido (DCH) ligands are highly electrochromic. ${ }^{20}$ Extensive studies on dinuclear ruthenium complexes with DCH bridging ligands (DCH-Ru complexes) have been carried out in our group in the past few years. ${ }^{21}$

These complexes have primarily been of interest because the characteristics of the IVCT transition provide quantitative information on the magnitude of the electronic coupling between the metal centers, and thus they are could be accordingly used as an excellent diagnostic tool. Nevertheless, the position and intensity of the IVCT transition in some cases mean that complexes of this sort could be exploited for their optical properties. Table 1.2 shows representative examples of this class of complex. ${ }^{22}$ Of course the field is not limited to ruthenium complexes, although these have been the most extensively studied because of their synthetic convenience and good electrochemical properties. Analogous complexes of other metals have also been prepared and could be equally effective NIR electrochromic dyes. 
Table 1.2. Examples of mixed-valence dinuclear ruthenium complexes showing NIR electrochromism.

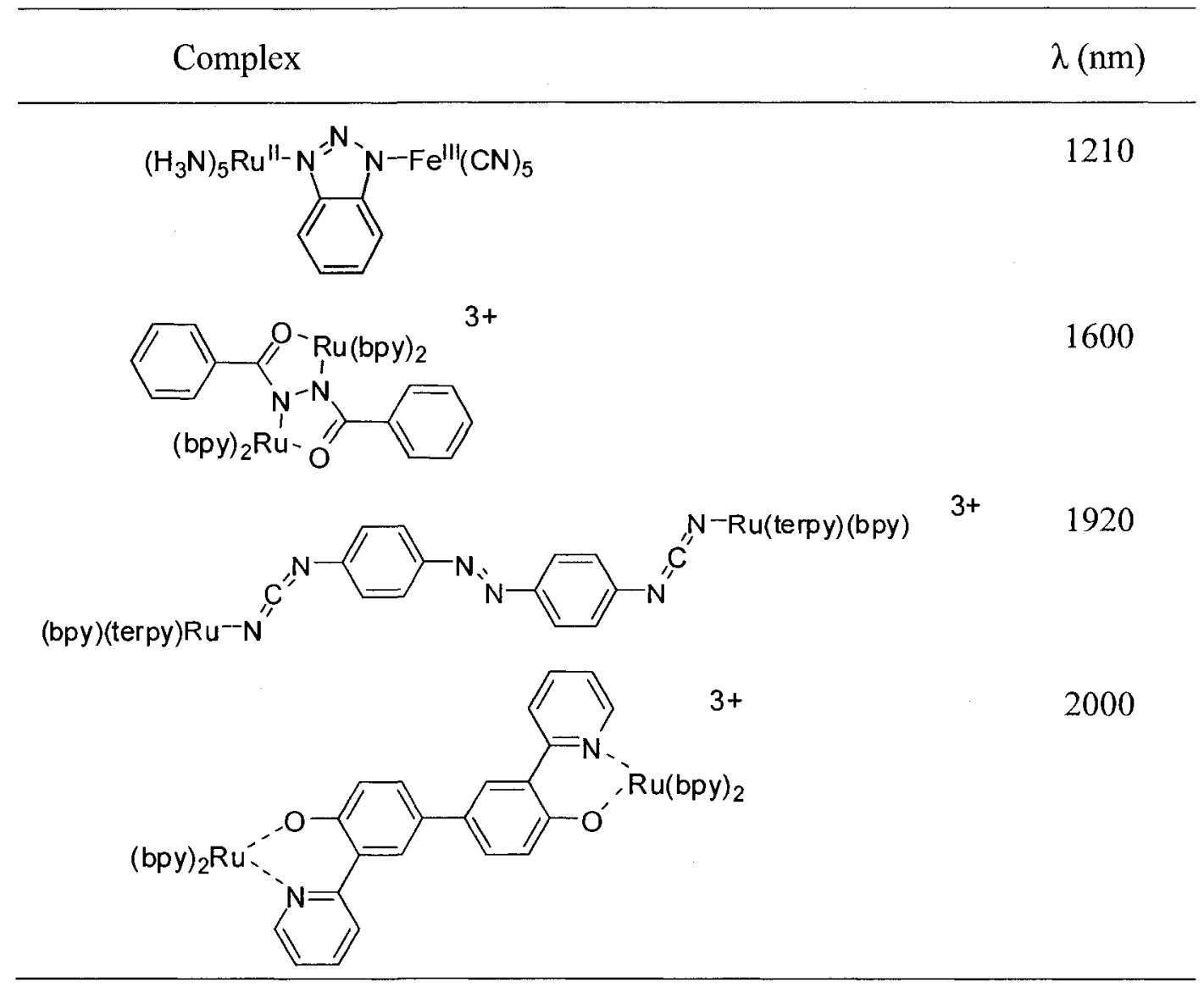

Wang and co-workers have prepared a dendritic DCH-Ru complex that shows a typical IVCT at $1550 \mathrm{~nm}$ in the mixed-valence $\mathrm{Ru}^{\mathrm{II}} / \mathrm{Ru}^{\mathrm{III}}$ state. $^{21 \mathrm{a}}$ The complex has pendant hydroxyl groups which react with a tri-isocyanate to give a crosslinked polymer which was deposited on an ITO substrate. Good electrochromic switching of $1550 \mathrm{~nm}$ radiation was maintained, with fast switching times (of the order of 1 second), over several thousand redox cycles.

Very recently, Wang and co-workers also reported a series of NIR electrochromic polymers containing the pendant DCH-Ru complexes. ${ }^{23}$ All the polymers are NIR electrochromic, displaying an intense absorption centered at 
$1600 \mathrm{~nm}$ upon oxidation to the mixed-valence state (Fiugre 1.4). These dinuclear ruthenium complex polymers show good thermal stability and film-forming ability, which may be potentially useful for NIR optical sensor, biomedical imaging, and telecommunication applications.

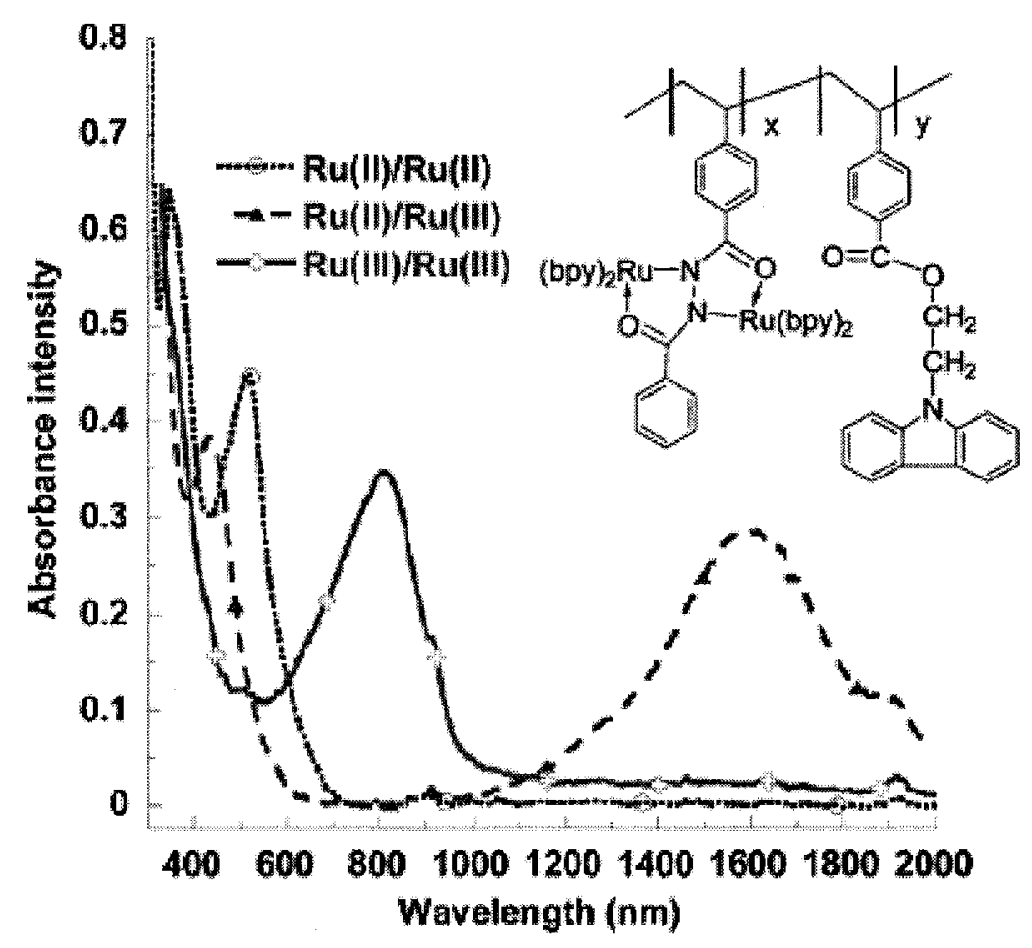

Figure 1.4. Structure of the dinuclear ruthenium complex polymer and its absorption spectra in three different oxidation states (adopted from Ref. 23).

\section{$1.2 \quad$ NIR electroluminescent materials}

Electroluminescence (EL) of organic materials has been known since the 1960s. ${ }^{24}$ Resulting devices are commonly called "organic light-emitting diodes" (OLED). Intense research activity, however, started in the late 1980s after the development of the multilayered cell structure by Tang and Vanslyke, ${ }^{25}$ who demonstrated the bright green emission of aluminum tris(8-hydroxyquinolinate) $\left(\mathrm{Alq}_{3}\right)$ in thin film organic layers. Another breakthrough came in 1990 when 
Burroughes and co-workers reported an EL device using a single layer of a $\pi$-conjugated polymer poly(phenylene-vinylene) (PPV), between metallic electrodes. ${ }^{26}$ Since then considerable research efforts have gone into the development of electroluminescent polymers for use in OLED.

In a typical OLED device, the thin film of light-emitting material is sandwiched between two electrodes, one of which has to be semitransparent. The process responsible for EL requires injection of electrons from one electrode and holes from the other, the capture of oppositely charged carriers (so-called recombination), and the radiative decay of the excited electron-hole state (exciton) produced by this recombination process.

Recently the development of emissive materials for OLED in the NIR region is becoming a major research subject since such materials are applicable to future optical communication, information processing, communication networks, and sensing applications. The organic NIR light-emitting materials that have been reported so far, are organic ionic dyes, ${ }^{27}$ organic rare-earth complexes comprising a central trivalent rare-earth ion, such as $\mathrm{Er}^{3+}, \mathrm{Nd}^{3+}$, or $\mathrm{Pr}^{3+}$ and etc., ${ }^{28}$ and conjugated polymers with donor-acceptor structure. ${ }^{29}$

\subsubsection{Organic rare-earth complexes}

In rare-earth metal ions the emission comes from $\mathrm{f}-\mathrm{f}$ transitions. Due to the core nature of the $4 \mathrm{f}$ electrons, which are effectively shielded from the influence of the external forces by the overlying $5 \mathrm{~s}^{2}$ and $5 \mathrm{p}^{6}$ orbitals, little vibrational coupling 
with the environment is seen, and the emission bands are extremely sharp and ion-specific, leading to pure colors.

In addition to the spectral profile of the complexes, the excitation mechanism of the central metal ion also differs widely from that of organic fluorescent compounds. In organic fluorescent compounds, the excited energy of the triplet state will be degraded through thermal deactivation processes without the emission of photons. Thus, the internal quantum efficiencies for devices using organic fluorescent compounds may be limited to approximately $25 \%$ by this process. In contrast, for rare-earth complexes, the metal ions are excited via intramolecular energy transfer from the triplet-excited states of the ligands. ${ }^{30}$ The excitation energy of the ligand's triplet state, which may be directly generated by carrier recombination, can also be utilized to excite the emitting center. Thus, there is no limitation, up to $100 \%$, of the internal quantum efficiencies for devices using rare-earth ion chelates as emitters.

Several rare-earth ions emit in the NIR region, and among them $\mathrm{Er}^{3+}$ plays a special role since doped silica fibers are currently at the heart of the optical amplification technology used in the long-haul communication systems operating in the $1.5 \mu \mathrm{m}$ spectral window. The erbium tris(8-hydroxy-quinoline) complex (ErQ) has gathered much attention especially after the demonstration of the first electrically excited organic IR emitter. ${ }^{28 a, 28 b}$ Gillin and Curry fabricated an Er-containing OLED. An ErQ complex was the emitting material. They observed $1540 \mathrm{~nm}$ sharp emission due to the $\mathrm{Er}^{3+}$ ion $4 \mathrm{f}$ transition at room temperature. 
Figure 1.5 shows the erbium-related EL along with the photoluminescence (PL) for the same region.

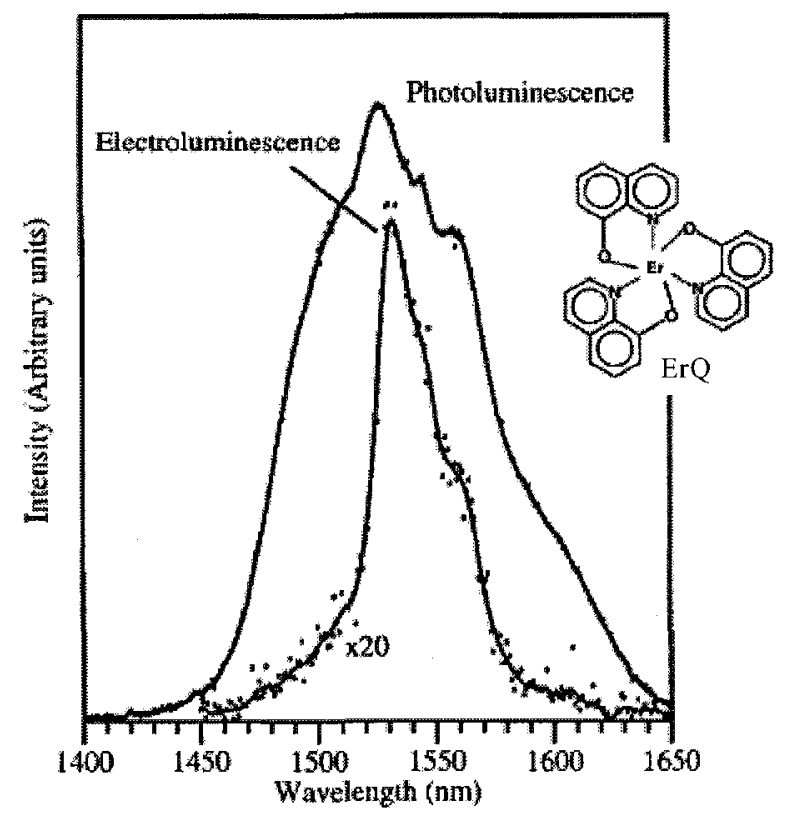

Figure 1.5. Structure of ErQ and its PL at $300 \mathrm{~K}$ (excited using the $457 \mathrm{~nm}$ line from an argon-ion laser) and EL obtained from an ITO/TPD $(500 \AA) / \mathrm{ErQ}(600 \AA) / \mathrm{Al}$ OLED. (adopted from Ref. 28a).

Integration of rare earth doped polymer materials into OLED devices might offer the potential for future realization of low cost, solution processable, electrically pumped optical emitters and amplifiers. Sun et al. studied the NIR emission of an $\operatorname{Er}(\mathrm{acac})_{3}$ (phen) complex. ${ }^{31}$ The complex was incorporated into a device with the structure ITO/PVK doped with $80 \mathrm{wt} \% \mathrm{Er}^{3+}$ complex/Al-Li/Ag, which exhibited a turn-on voltage of $\sim 12 \mathrm{~V}$ and the NIR emission at $1.54 \mu \mathrm{m}$ characteristic of $\mathrm{Er}^{3+}$, along with some visible luminescence in the region 480-610 $\mathrm{nm}$, attributed by the authors to an exciplex formed by PVK and the Er complex.

Harrison et al. described the utilization of conjugated polymer/Er or $\mathrm{Yb}$ porphyrin complexes for NIR emission (Figure 1.6). The $\mathrm{Yb}$ complex was first 
blended with poly[2-methoxy-5-(2'-ethyl-hexyloxy)-1,4-phenylene vinylene] (MEHPPV), as this polymer's emission spectrum overlaps with the $\mathrm{Q}$ band of the porphyrin. In a second iteration a bis-alkoxysubstituted poly( $p$-phenylene) (PPP-OR11) was developed, as its emission spectrum overlaps with the porphyrin's Soret band. Both host polymers should thus allow for efficient Förster energy transfer to the complex. Devices with the structure ITO/PEDOT-PSS/polymer blend with $\mathrm{Yb}$ complex/Ca/Al were built. Nearly pure Yb-based EL was observed for the device with 5\% complex and MEH-PPV as the host, with a turn-on voltage of $4 \mathrm{~V}$ and a NIR EL efficiency of $1.5 \times 10^{-2} \%$ at $7 \mathrm{~V}$. The authors confirm that non-radiative decay pathways are mostly responsible for the low device efficiency, by observing that the PL intensity is strongly dependent on the temperature. Use of PPP-OR11 as the host with $20 \% \mathrm{Yb}$ complex leads to a device with a turn-on voltage of $4 \mathrm{~V}$ and a greatly improved external quantum efficiency of $0.1 \%$.

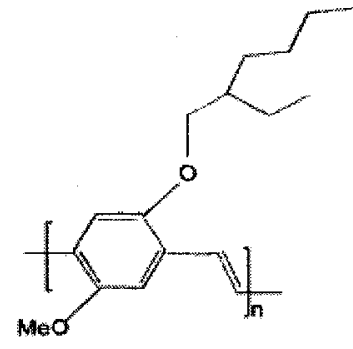

MEHPPV

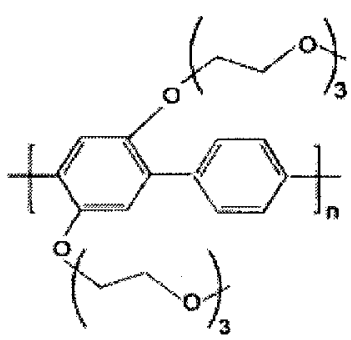

PPPOORT1

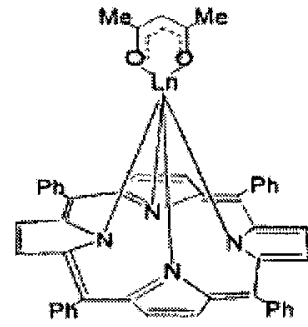

$L n=Y^{3+}$ or $\mathrm{Er}^{3+}$ LuTPP Jacac

Fgiure 1.6. Structures of MEH-PPV, PPP-OR11 and Ln(TPP)acac. 
Substitution of the transition metal complex in the coordination sphere of the $\mathrm{Yb}$ for a pyrazolylborate ligand leading to $\operatorname{Ln}(\mathrm{TPP}) \mathrm{Tp}$ complex was accomplished by Kang and co-workers. ${ }^{28 n}$ This allowed the expansion of the architecture of the OLED and demonstrated that, due to the good charge transport properties of the TPP ligand, other non-conducting polymer hosts can be utilized. The structure of $\operatorname{Ln}(\mathrm{TPP}) \mathrm{Tp}$ and EL spectra of the complexes are shown in Figure 1.7. The diode devices with the configuration ITO/PEDOT-PSS/PPP-OR11/Ln(TPP)Tp/Ca/Al were fabricated. Turn-on voltages between 4 and $5 \mathrm{~V}$ were observed and emission at $970 \mathrm{~nm}$ was observed with an irradiance up to $10.0 \mu \mathrm{W} \mathrm{cm}$ and a current density of $315 \mathrm{~mA} \mathrm{~cm}^{-2}$ at 9 $\mathrm{V}$ and an external efficiency of $1.3 \times 10^{-2} \%$ at $30 \mathrm{~mA} \mathrm{~cm}$. When using non-conducting host polymers such as PMMA, poly(butyl methacrylate), and polycarbonate with this same emitting complex, higher turn-on voltages of $\sim 8 \mathrm{~V}$ are necessary, possibly due to interfacial effects adding resistive barriers. However, the external quantum efficiencies are comparable, confirming that the charge transport and recombination mechanism is situated mostly on the emitting molecules and not on the polymer host. 

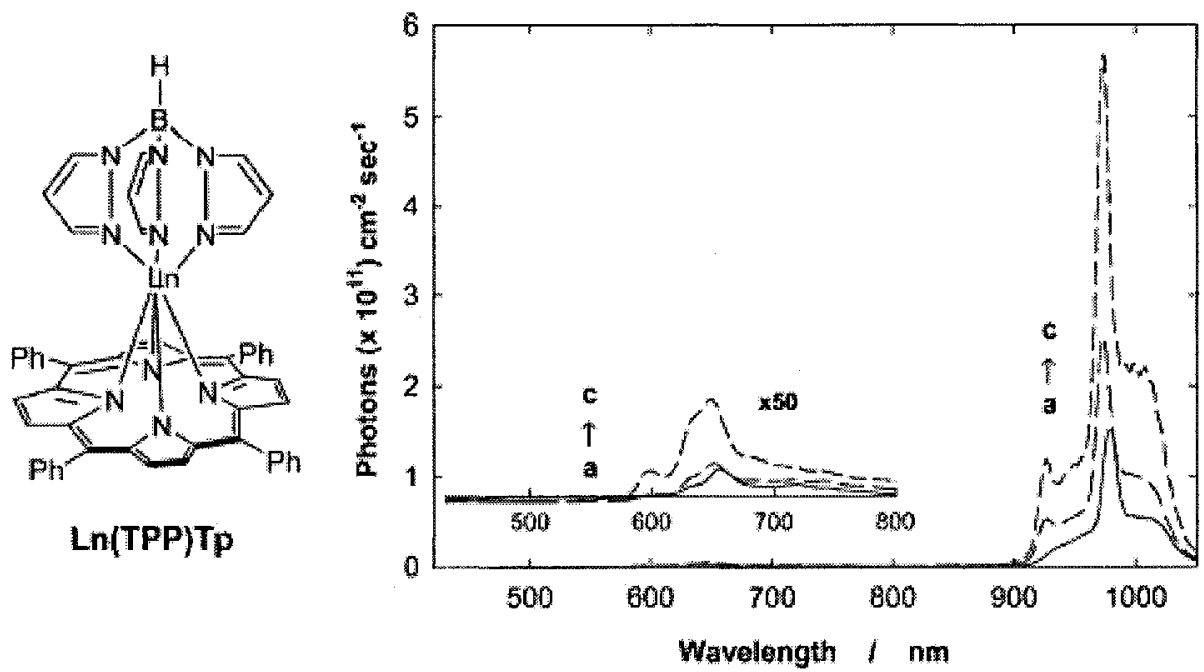

Figure 1.7. Structure of Ln(TPP)Tp and EL spectra of (a) 5, (b) 10, and (c) 15 mol\% Yb(TPP)Tp in PPP-OR11 at $8 \mathrm{~V}$ (adopted from Ref. 28n).

Slooff et al. studied a lissamine-functionalized terphenyl complex of $\mathrm{Nd}$

(Ls. $\left.\mathrm{Nd}^{3+}\right),{ }^{281}$ shown in Figure 1.8. Doping of this complex into poly(dioctylfluorene-alt-benzothiadiazole) (F8BT) yields a film in which the emission of the host is quenched and combined red PL from the ligand and NIR PL from the $\mathrm{Ln}$ ion are observed instead. This complex and its host were incorporated into a device with the structure ITO/PEDOT:PSS/F8BT blended with $10 \mathrm{wt} \%$ Ls. $\mathrm{Nd}^{3+} / \mathrm{Ca} / \mathrm{Al}$. The EL spectrum from this device shows contributions from both the ligand and the $\mathrm{Nd}$ ion. 


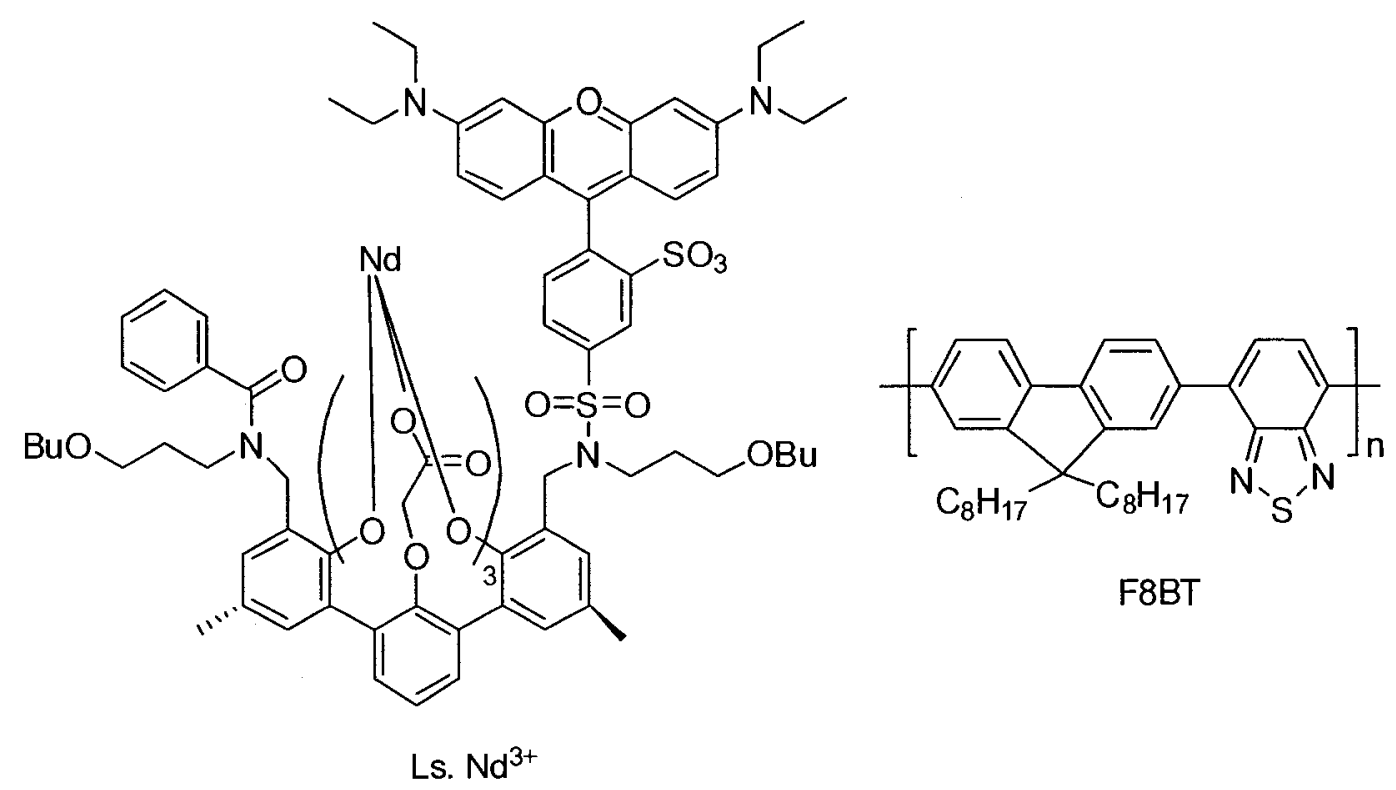

Figure 1.8. Structures of Lissamine-functionalized organic neodymium complex (Ls. $\mathrm{Nd}^{3+}$ ) and F8BT.

Kawamura et al. prepared $\operatorname{Ln}(\mathrm{DBM})_{3}(\mathrm{dpphen})(\mathrm{Ln}=\mathrm{Nd}$, Er and $\mathrm{Yb})$ complexes (Figure 1.9) and built devices with BCP and TPD. ${ }^{32}$ EL in the NIR was observed for all three ions, $\mathrm{Nd}, \mathrm{Er}$ and $\mathrm{Yb}$, with turn-on voltages of 11,18 and 9 $\mathrm{V}$, respectively. By comparing the behavior of these with a Eu-based LED, the authors estimated an efficiency of $7 \times 10^{-3} \%$ for the $\mathrm{Nd}, 3 \times 10^{-2} \%$ for the $\mathrm{Yb}$ and $1 \times 10^{-4} \%$ for the Er-based device. A rapid decrease of efficiency for all three devices was observed at higher current densities, which the authors attributed to triplet-triplet annihilation.

$\operatorname{Pr}(\mathrm{DBM})_{3}(\mathrm{dpphen})$ and $\operatorname{Ho}(\mathrm{DBM})_{3}(\mathrm{dpphen})$ were described by $\mathrm{Li}$ and co-workers for EL from Pr and Ho (Figure 1.9). ${ }^{28 d, 28 t}$ The Pr-containing device, with the architecture ITO/TPD/TBD blended with 66 wt\% $\operatorname{Pr}(\mathrm{DBM})_{3}(\mathrm{dpphen}) / \mathrm{Ag}-\mathrm{Mg}$, displayed its main emission at 1014 and $1065 \mathrm{~nm}$, in addition to exciplex emission in the range $450-700 \mathrm{~nm}$. The turn-on voltage was 
reported to be $8 \mathrm{~V}$, with a current density of $90.5 \mathrm{~mA} \mathrm{~cm}{ }^{-2}$ being measured under $12 \mathrm{~V}$. While exciplex emission in the visible region was also observed in the case of the device with the configuration ITO/TPD/Ho(DBM $)_{3}($ dpphen $) / \mathrm{Ag}-\mathrm{Mg}$, three bands corresponding to the NIR emission in the $980-1500 \mathrm{~nm}$ region were seen with a turn-on voltage of $9 \mathrm{~V}$.

Most recently O'Riordan et al. studied the $\mathrm{Nd}$ complex of hydroxyphenalenone $\left(\mathrm{Nd}(\text { phenalenone) })_{3}\right)$ (Figure 1.9). ${ }^{28 \mathrm{j}} \mathrm{A}$ device with the configuration ITO/PEDOT/PVK blended with $\mathrm{Nd}$ (phenalenone) $3 / \mathrm{Al}$ was fabricated. A high turn-on voltage of $30 \mathrm{~V}$ was measured for this device, with a maximum light output of $4.0 \mathrm{nW}$ at $460 \mathrm{~mA} \mathrm{~cm}^{-2}$ and $42 \mathrm{~V}$, for an external quantum efficiency of $0.003 \%$. Replacement of the $\mathrm{Al}$ with a $\mathrm{Ca} / \mathrm{Al}$ cathode led to an increase of the efficiency to $0.007 \%$ and a maximum irradiance of $8.5 \mathrm{nW}$ at $480 \mathrm{~mA} \mathrm{~cm}^{-2}$ and $42 \mathrm{~V}$.

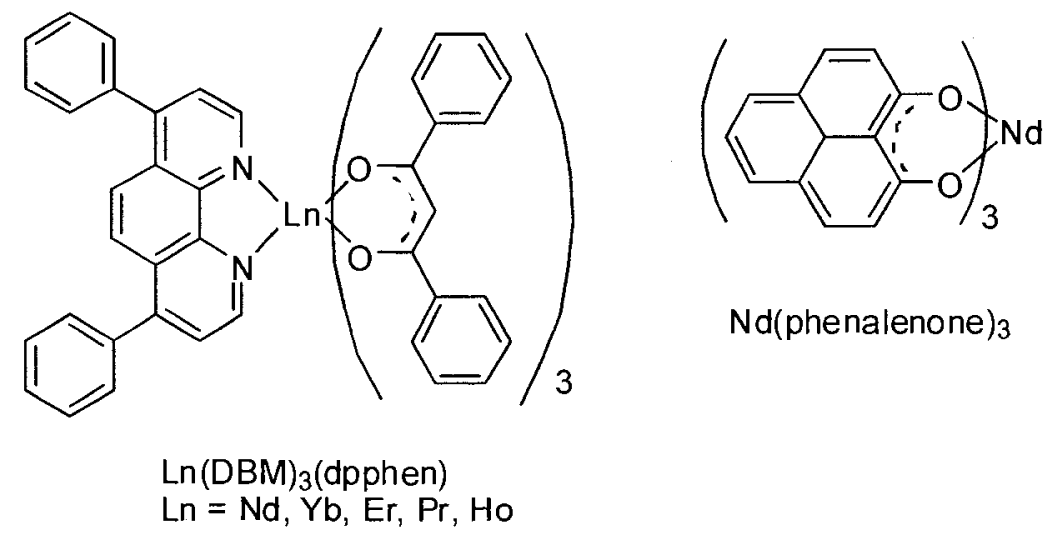

Figure 1.9. Structures of $\mathrm{Nd}(\mathrm{DBM})_{3}(\mathrm{TPPO})_{2}$ and $\mathrm{Ln}(\mathrm{DBM})_{3}(\mathrm{dpphen})(\mathrm{Ln}=\mathrm{Nd}$, $\mathrm{Yb}, \mathrm{Er}, \mathrm{Pr}, \mathrm{Ho})$.

To date no examples of polymers covalently incorporating $\mathrm{Ln}(\mathrm{III})$ ion complexes for NIR EL have been described. However, the utility of NIR 
luminescent polymers in the field of telecommunications is unquestionable and their pursuit remains interesting. ${ }^{33}$ For this purpose, Destri et al. described thiophene-based oligomers, ${ }^{34}$ into which Er can be incorporated, shown in Figure 1.10. The authors observed that upon mixing of Er with the oligomers in anhydrous pyridine, pure Er-centered emission at $1540 \mathrm{~nm}$ was observed and this luminescence was almost as intense as the one observed from the comparison material, ErQ. These oligomers are therefore promising precursors of co-polymers for NIR EL.<smiles>O=C([O-])Cc1c(-c2cccs2)sc(-c2cccs2)c1CC(=O)[O-]</smiles><smiles>O=C([O-])Cc1c(-c2cccs2)sc(-c2ccc(-c3sc(-c4cccs4)c(CC(=O)[O-])c3CC(=O)[O-])s2)c1CC(=O)[O-]</smiles>

Figure 1.10. Terthiophene and quinquethiophene acetate oligomers for NIR Er-centered luminescence.

\subsubsection{Organic ionic dyes}

Although NIR-active organic ionic dye was investigated in $1999,{ }^{35}$ there is only a limited number of electroluminescent organic ionic dyes have been reported to date.

Suzuki and co-workers reported the NIR EL of an ionic dye, ${ }^{27 a}$ 2-[6-(4-dimethylaminophenyl)-2,4-neopentylene-1,3,5-hexatrienyl]-3-methylbenz othiazolium perchlorate (LDS 821) doped in PVK with an electron transporting material, 2-(4-biphenylyl)-5-(4-t-butylphenyl)-1,3,4-oxidiazole $\quad(\mathrm{PBD}) . \quad$ The structure of LDS821 is shown in Table 1.3. The studies revealed that the PBD 
concentration increase from 10 to $30 \mathrm{wt} \%$ improved the EL characteristics. The turn-on voltage was reduced from 15 to $7 \mathrm{~V}$, and the external EL quantum efficiency increased from $0.0005 \%$ to $0.015 \%$. This is because the increase in the PBD concentration lessened the imbalance in the supply of electrons and holes into the PVK layer.

Another electroluminescent organic ionic dye, IR1051 was reported by Suzuki in $2002 .{ }^{27 c}$ The structure of IR1051 is shown in Table 1.3. Single-layer LED were fabricated on an ITO coated glass substrate by spin coating a 180-300 nm PVK film containing $1 \mathrm{wt} \%$ of IR1051 and $30 \mathrm{wt} \%$ of PBD, and then vacuum evaporating an $\mathrm{Al}$ electrode. The LED exhibits EL peaking at $1150 \mathrm{~nm}$ with a shoulder at $990 \mathrm{~nm}$. The authors didn't mention other electroluminescent properties of this material.

In addition, Mal'tsev and co-workers reported an electroluminescent organic ionic dye, TCC, in 2004 (Table 1.3). ${ }^{27 e}$ The electroluminescent properties of single layer LED based on TCC and TCC doped cardoaromatic polyimides (CAPI) are explored. In the TCC-containing CAPI films, a single narrow emission with a maximum at $748 \mathrm{~nm}$ is observed and the films containing $J$-aggregates and some free TCC molecules give only a very narrow EL band in the NIR domain, with $\lambda_{\max }=815 \mathrm{~nm}$. This band can be related to the nanocrystalline $J$-aggregate-phase in the polymer composite. 
Table 1.3. Structures of organic ionic dyes and their EL emission peaks based on the LEDs.

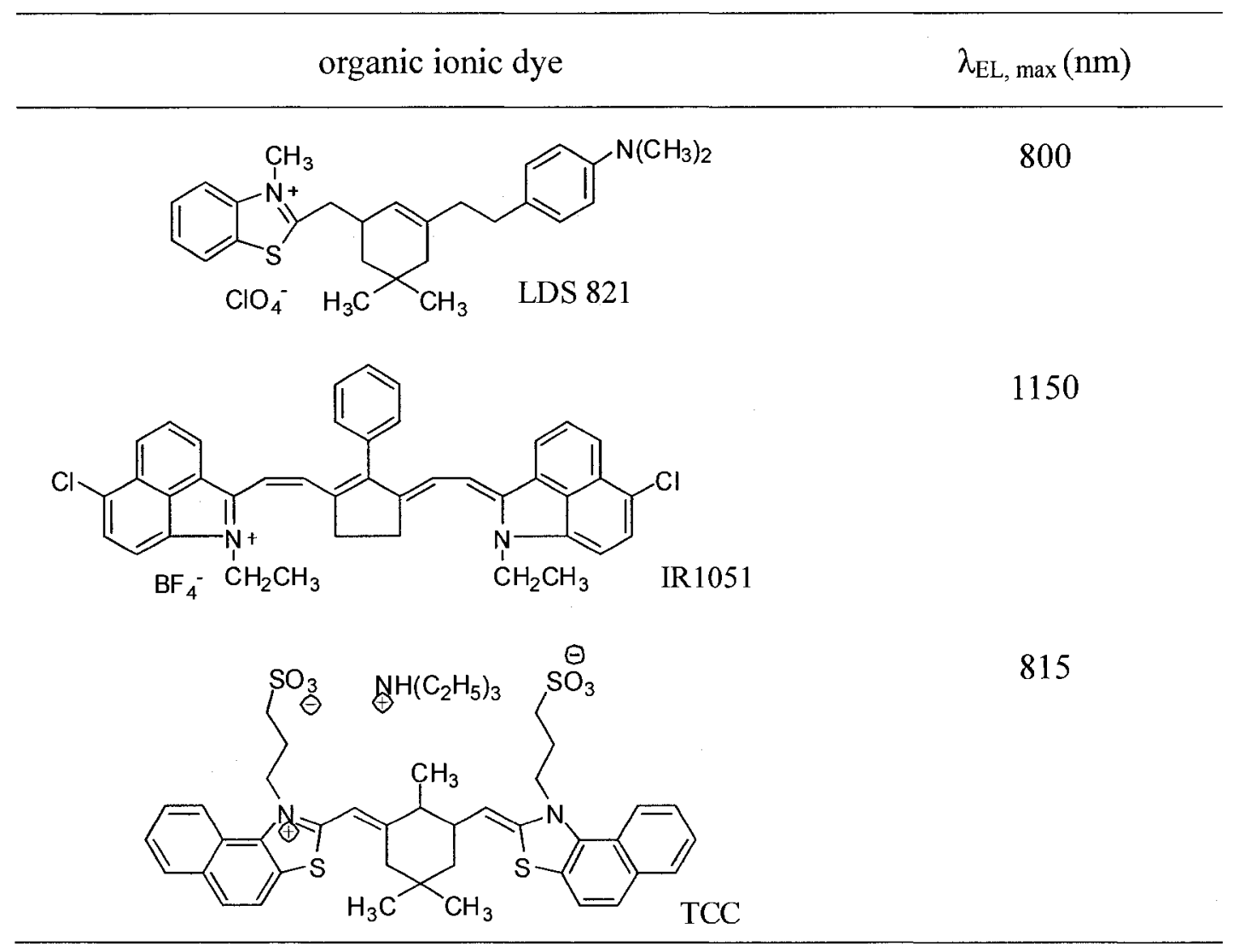

\subsubsection{Conjugated polymers}

Inorganic semiconducting and organic dye materials have to be deposited as thin films by the relatively expensive techniques of sublimation or vapor deposition, which are not well suited to fabricate of large-area devices. For these reasons, the possibility of using fluorescent conjugated polymers, which can be readily deposited from solution as thin films over large areas by spin-coating or doctor blade techniques, is most attractive. Based on these considerations, NIR emission polymers have been received much research interest recently.

Andersson and co-workers synthesized a series of different substituted poly(thiophenes) (Figure 1.11). ${ }^{29 d}$ They tuned the conjugation length of 
poly(thiophenes) by altering the substitutes. Upon thermal treatment of the polymer I film, an irreversible change to a new structure $\left(I^{*}\right)$ is obtained. The PLEDs from polymers I-IV give NIR and red (I* , I), orange (II), green (III) and blue (IV) colors (Figure 1.14). EL maxima of PLED based on polymer I* is at $800 \mathrm{~nm}$, which is the longest EL wavelength obtained with poly(thiophenes) to date. The diodes prepared from the polymers have an increasing turn-on voltage with decreasing wavelength of the absorption maximum of the polymers. A low turn-on voltage of $1.4 \mathrm{~V}$ and an external quantum efficiency of $0.3 \%$ measured at $6 \mathrm{~V}$ were obtained for the device based on polymer I*.

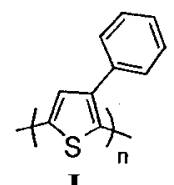

I

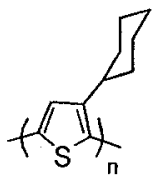

III

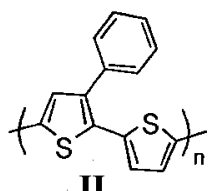

II

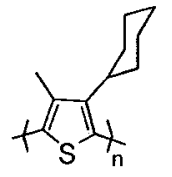

IV

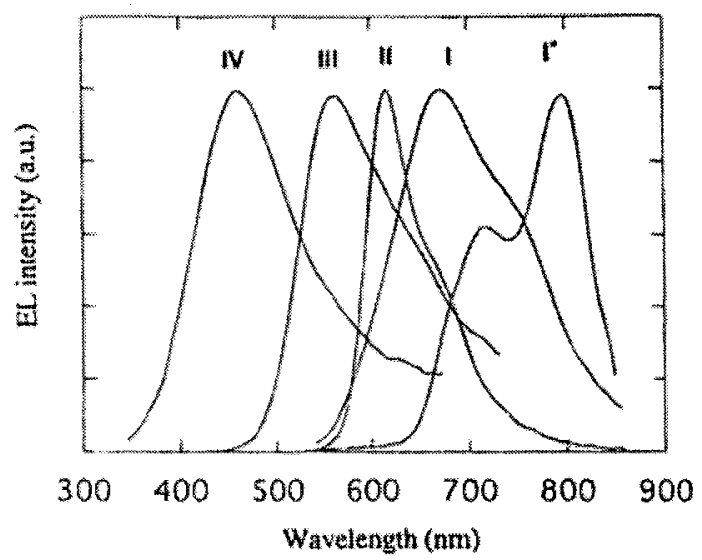

Figure 1.11. Structures of polymers I-IV and their EL spectra (adopted from Ref. 29d).

Chen and co-workers reported $1 \mu \mathrm{m}$ PL and EL from a conjugated polymer. ${ }^{29 e}$ The polymer is based on a repeating unit consisting of alkyl-substituted fluorene coupled to a [1,2,5]-thiadiazolo-[3,4]-quinoxaline unit (electron acceptor) fenced by two thiophene rings (electron donors) (Figure 1.12). Recent molecular orbital calculations have shown that the hybridization of the energy levels of the donor and the acceptor moieties result in a D-A system with unusually low 
HOMO-LUMO separation. ${ }^{36}$ The turn-on voltage of PLED occurs at $0.7 \mathrm{~V}$. The external quantum efficiency is estimated to be between $0.03 \%$ and $0.05 \%$. The maximum position of the EL spectrum is $970 \mathrm{~nm}$. This work demonstrates a new design to realize NIR electroluminescent conjugated polymers.

Reynolds introduced the D-A structure to PPVs, in which 1,4-(2,5-dihexadecyloxyphenylene) and 5,8-linked 2,3-diphenylpyrido[3,4-b] pyrazine were used as a donor and an acceptor, respectively. ${ }^{29 f}$ The resulting polymer (PPyrPyrPV) (Figure 1.12) in LED exhibits the EL centered at $800 \mathrm{~nm}$. The turn-on voltage was $8 \mathrm{~V}$ for the PPyrPyrPV device and the maximum intensity of the emission in the PPyrPyrPV devices was low with a value of 65 $\mathrm{nW} \mathrm{cm} \mathrm{cm}^{-2}$.

The NIR PLED with a bilayer structure was reported by $\mathrm{Cao},{ }^{29 a}$ with a configuration of ITO/PEDOT/L1/L2/Ba/Al, where $\mathrm{L} 1$ is $\mathrm{P}-\mathrm{PPV}$ and $\mathrm{L} 2$ is a copolymer (PFHDNT10) (Figure 1.12). The EL peak of the device from PFHDNT10 is at $750 \mathrm{~nm}$. The external quantum efficiency is up to $2.1 \%$ at the current density of $35 \mathrm{~mA} \mathrm{~cm}^{-2}$.

Cao group reported another series of NIR EL random copolymers (PFO-DTTP) (Figure 1.12) derived from low-band-gap 2,3-dimethyl-5,7-dithien-2-yl-thieno[3,4-b]pyrazine. ${ }^{29 g}$ The highest external quantum efficiency of the LEDs based on PFO-DTTP5 reached $0.6 \%$ with an emission peak of ca. $734 \mathrm{~nm}$. The emission was shifted to $780 \mathrm{~nm}$ for a device made from PFO-DTTP30. 


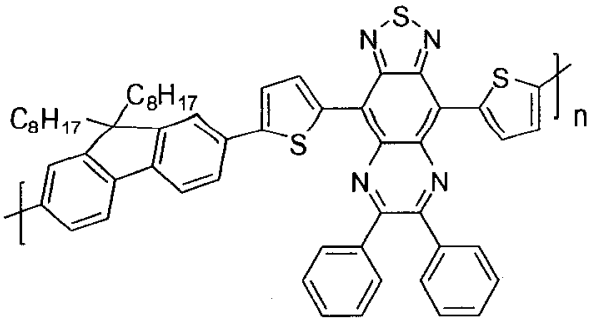

AFO-Green 1

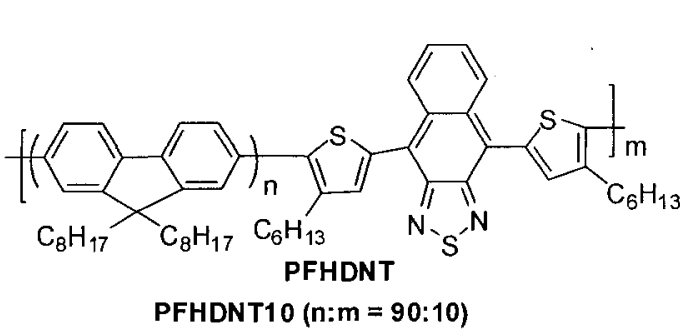

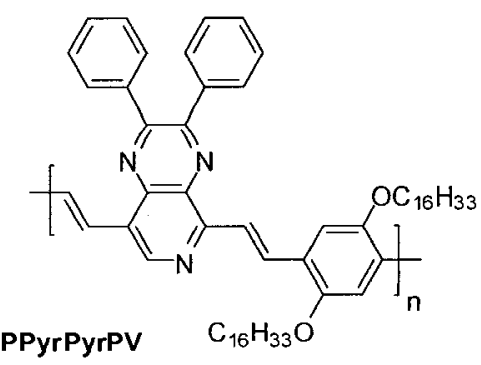

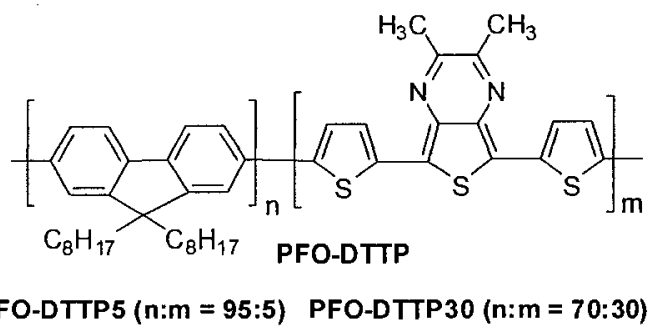

Figure 1.12. Structures of NIR electroluminescent polymers.

In summary, among these NIR electroluminescent materials, ionic dyes and conjugated polymers are the only examples, where the luminescence originates from organic components. However, there are few ionic dyes and conjugated polymers that show luminescence longer than $1.2 \mu \mathrm{m}$. Organic rare-earth complexes exhibit narrow bandwidth emission in the 1.0-1.6 $\mu \mathrm{m}$ region originating from the radiative $f-f$ transitions of the rare-earth ions. However, since the $f-f$ transition is in principle a parity-forbidden process, there remains an essential challenge to improve EL quantum efficiency.

\subsection{Metal complex polymers}

Most of the conjugated polymers contain carbon or other heteroatoms such as nitrogen, oxygen, and sulfur. Examples of metal-containing conjugated polymers are also known, ${ }^{37}$ and many of them are organometallic polymers in which metal-carbon bonds constitute part of the polymer main chain. A metal complex can 
be attached to a polymer using various methods. ${ }^{38}$ The metal complex can be electrostatically, coordinatively, or covalently bonded to a polymer on the main chain or side chain. 2,2-Bipyridine (bpy) is one of the most common ligands incorporated in conjugated polymers. ${ }^{39}$ This ligand allows the coordination of a variety of transition metals. This coordination process also forms the basis of metal ion sensing, in which the luminescence properties of the polymer can be changed upon binding with different metals. ${ }^{40}$ Structural variation in metal-containing conjugated polymers can be achieved by changing the ligand or metal. Conjugated polymers with other kinds of bidentate ligands such as 1,10-phenanthroline (phen), ${ }^{41}$ benzimidazole, ${ }^{42}$ and tetrapyridophenazine ${ }^{43}$ have also been reported. The interactions between the metals and polymer chain were also studied. ${ }^{44}$

\subsubsection{Metal complexes in conjugated main chain}

The synthesis of a series of PPV incorporated with a $\left[\mathrm{Ru}(\operatorname{tpy})_{2}\right]^{2+}$ complex is shown in Scheme 1.2. ${ }^{45}$ The polymers were prepared using the palladium catalyzed Heck coupling reaction. The absorption spectra of the polymers reveal some interesting features. When the metal content in the polymer is low, the spectrum shows two absorptions due to the $\pi$-conjugated main chain $(\sim 430 \mathrm{~nm})$ and the MLCT transition $(\sim 500 \mathrm{~nm})$. For the polymers with higher ruthenium complex content, the absorption due to the conjugated main chain disappears because increasing metal complex content in the main chain results in interruption of the $\pi$-conjugation. The photoconductivity was measured at different wavelengths and 
found to increase with an increase of the metal content and to be in the order of $10^{-12} \Omega^{-1} \mathrm{~cm}^{-1}$. The photocurrent action spectra of the polymers closely resembled their corresponding absorption spectra, and maximum photocurrent response was observed at $500 \mathrm{~nm}^{46}$ This clearly showed that the enhancement in photocurrent is due to the presence of a ruthenium complex in the polymers.
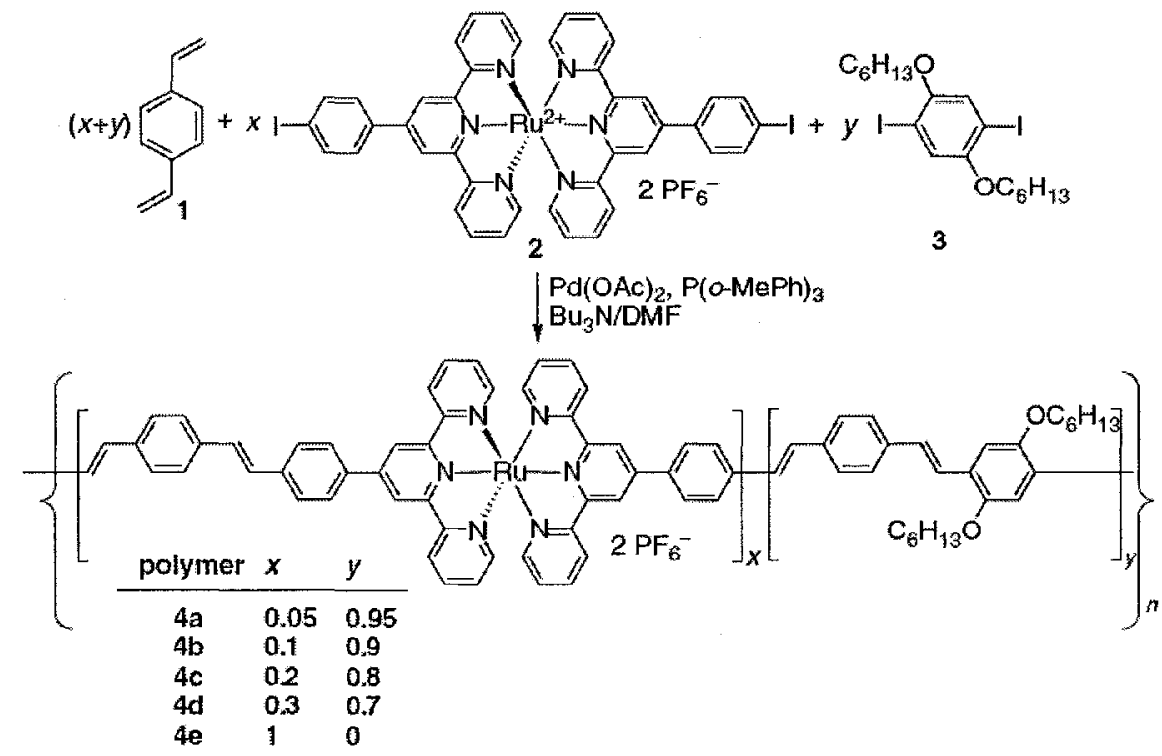

Scheme 1.2. Synthesis of the ruthenium complex polymers (adopted from Ref.45).

In another series of polymers, dipyridophenazine complexes of ruthenium or rhenium were polymerized with 5,8-dibromo-2,3-dihexylquinoxaline, and divinylbenzene (Scheme 1.3). ${ }^{47}$ Due to the poor solubility of the rhenium complex-containing polymers, detailed studies were therefore carried out only in the ruthenium-containing polymers.

The authors found that the carrier mobilities are strongly dependent on the metal complex content. Both the hole and electron-carrier mobilities of polymer $\mathbf{8 e}$ are one order of magnitude higher than those of polymer 8a. This strongly suggests 
the important role played by the ruthenium complex in the charge-transport process.

The redox reactions happened in the metal center and the ligand can facilitate the hole and electron-transport processes, respectively.

Single-layer EL devices (ITO/polymer/Al) were fabricated from the polymers. Emission bands from both main chain and metal complex can be observed, and their relative intensities are also dependent on the metal complex content. The external quantum efficiency of the device was estimated to be $0.6 \%$.
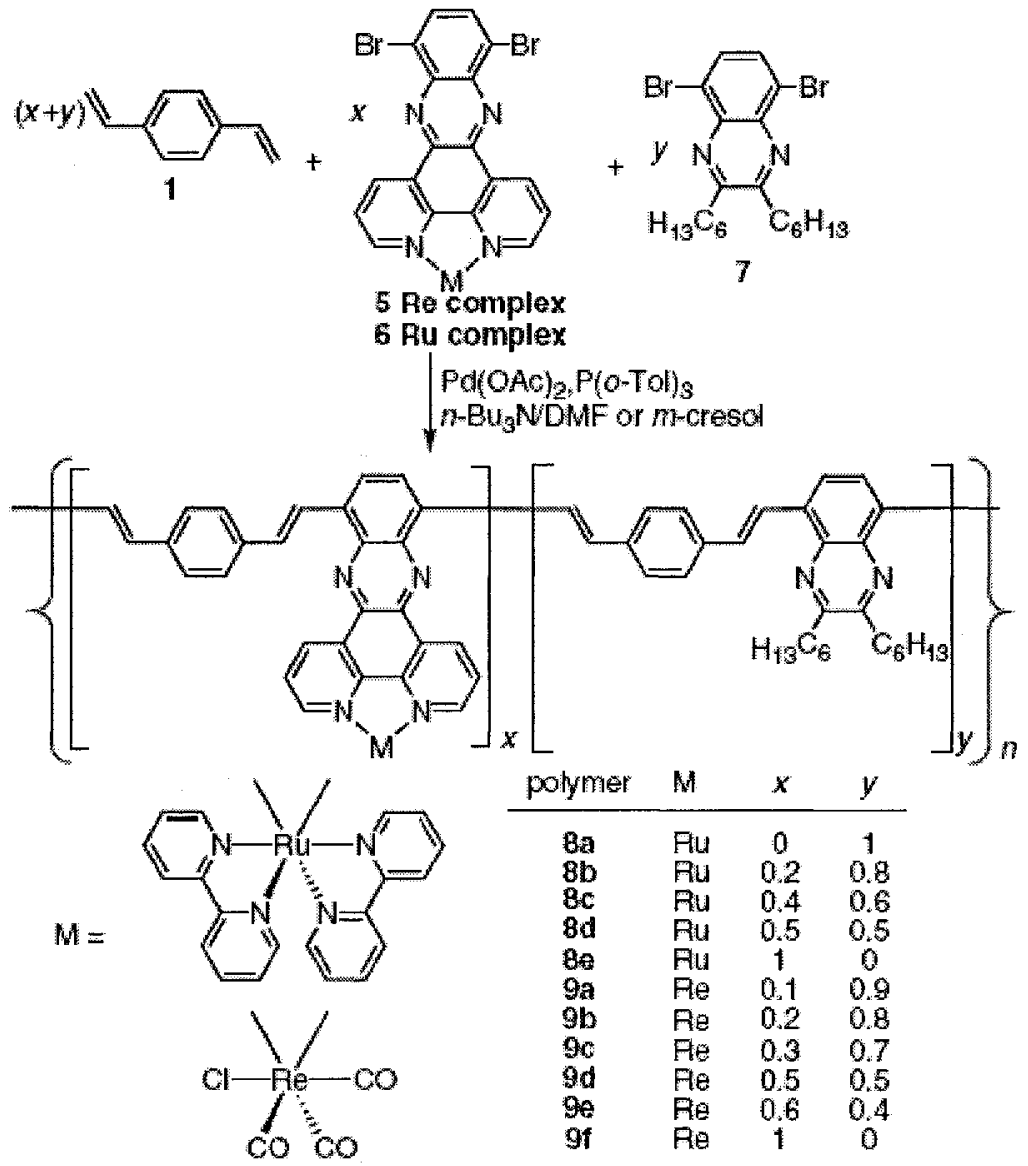

Scheme 1.3. PPVs incorporated with ruthenium or rhenium dipyridophenazine complexes (adopted from Ref.47). 
The effect of metal complex content to the charge-carrier mobility was further investigated in another series of metal-containing conjugated polymers. Three series of ruthenium- or rhenium-containing polymers with oxadiazole substituted bpy or phen ligands are shown in Figure $1.13 .^{48}$ It has been well known that aromatic 1,3,4-oxadiazole is a good electron-transport molecule. ${ }^{49}$ They can enhance the electron-carrier mobility and facilitate the charge separation after the photosensitizing process. ${ }^{50}$ The hole and electron mobilities of polymers with oxadiazole substituted bpy on the main chain are in the order of $10^{-4} \mathrm{~cm}^{2} \mathrm{~V}^{-1}$ $\mathrm{s}^{-1}$, and are strongly dependent on the metal content. These values are significantly higher than PPV derivatives. Similar properties were also observed in polymers with phen ligands.

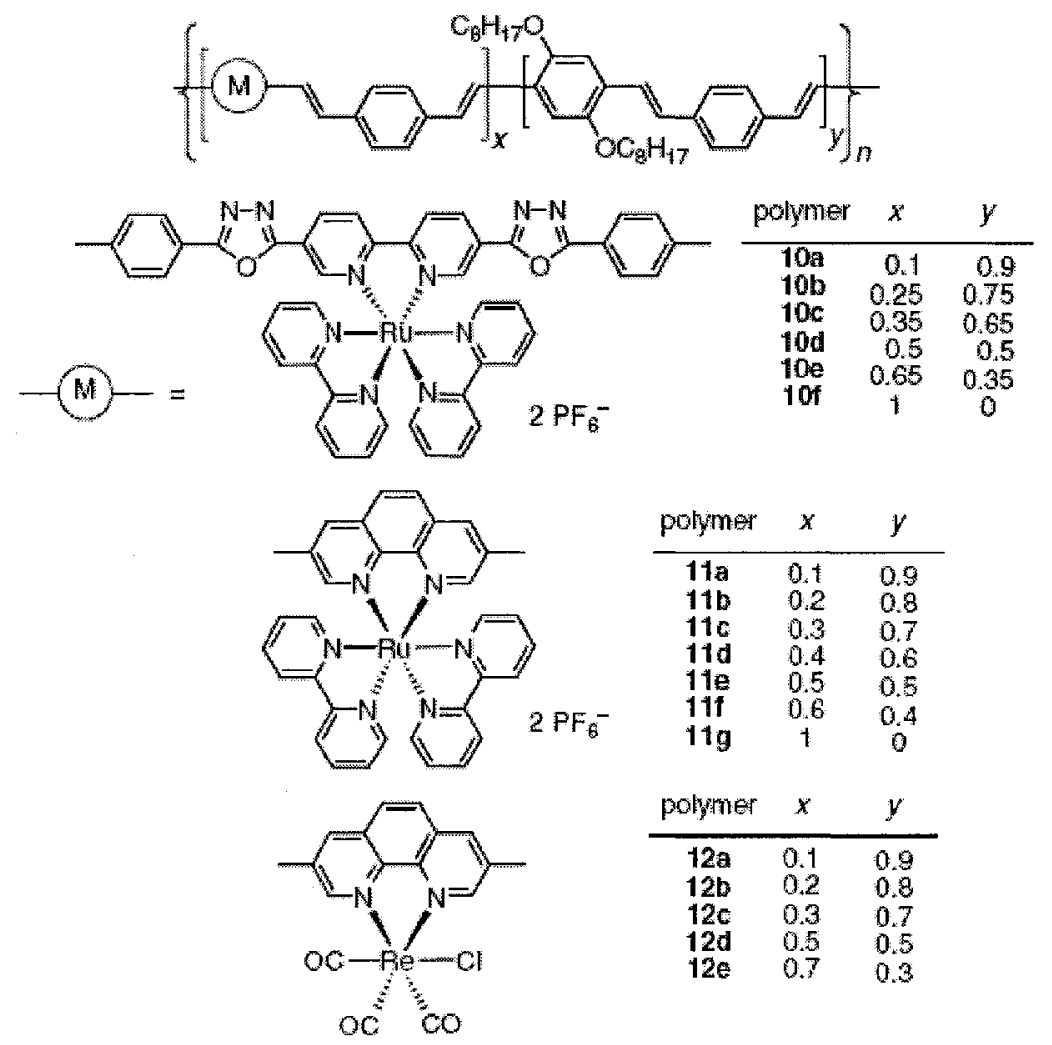

Figure 1.13. Structures of ruthenium- and rhenium-containing polymers based on oxadiazole-substituted bpy and phen ligands (adopted from Ref. 48). 
The electroluminescent properties of the polymers were tested. The EL spectrum of 10d is dominated by the main chain emission at $590 \mathrm{~nm}$, and the metal complex emission only appeared as a small shoulder at $\sim 650 \mathrm{~nm}$. On the other hand, polymer 10f only exhibits a relatively narrow emission peak centered at $690 \mathrm{~nm}$. Like the previous series of polymers, this is also explained by the energy transfer process between the main chain and the metal complexes. The turn-on voltages of the devices range from 6 to $8 \mathrm{~V}$, and the external quantum efficiency was between 0.05 and $0.2 \%$.

By using a similar design strategy, metal complex polymers that have multifunctional groups for hole transport, electron transport, and light emitting were developed. $^{51}$ They also exhibited bipolar charge transport character. ${ }^{52}$ In addition, Yasuda and co-workers demonstrated the tunable optical properties of conjugated polymers containing phen units by metal complexation. ${ }^{53}$ The obtained metal complex polymers show dramatic changes in the emitted light. $\mathrm{Zn}(\mathrm{OAc})_{2}$, Eu(dibenzoylmethane $)_{3}, \operatorname{Ir}(\text { phenylpyridine })_{2}$ coordinated polymers emitted the green $\left(\lambda_{\max }=536 \mathrm{~nm}\right)$, red $\left(\lambda_{\max }=612 \mathrm{~nm}\right)$ and orange $\left(\lambda_{\max }=604 \mathrm{~nm}\right)$ light, respectively (Figure 1.14). 

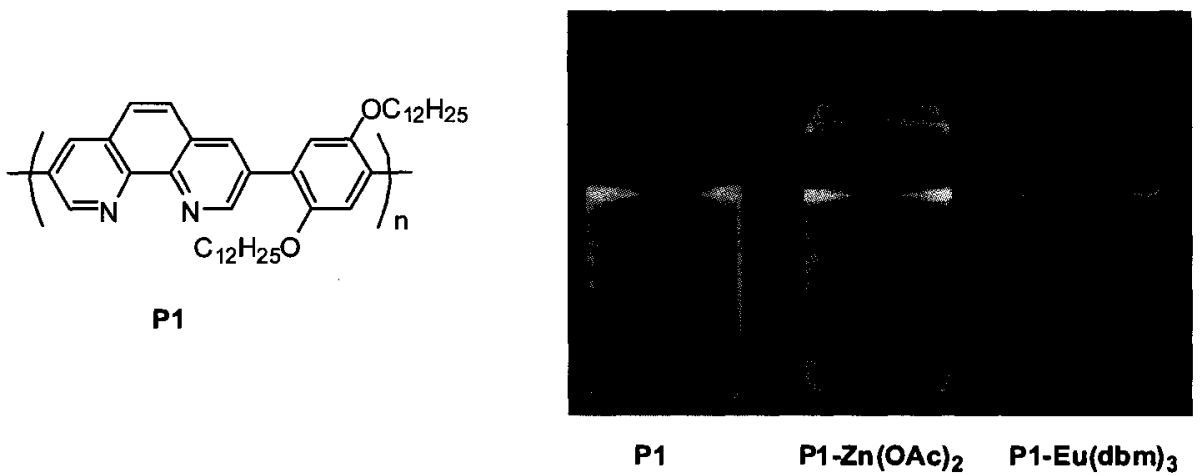

Figure 1.14. Structure of the polymer (P1) and a photograph showing emission of light from $\mathrm{P} 1$ and its metal complexes in THF (adopted from Ref.53).

The ruthenium complexes can be attached to more rigid polymers. This was usually achieved by first synthesizing the metal free polymers, followed by metal complexation reaction. Although most rigid polymers are only soluble in few solvents, the metal-containing rigid polymers usually exhibited higher solubility in polar solvents because of the presence of ionic complex species. Derivatives of poly(benzobisoxazole) and poly(benzobisthiazole) were prepared by $\mathrm{Yu}$ and co-workers (Scheme 1.4) ${ }^{54}$ These polymers contain a linear and rigid main chain and are extremely thermally stable. In addition, in the luminescence spectra, emissions originated from both conjugated main chain and metal complexes were observed. However, detailed studies on all polymers were not carried out because some polymers had poor film quality. 


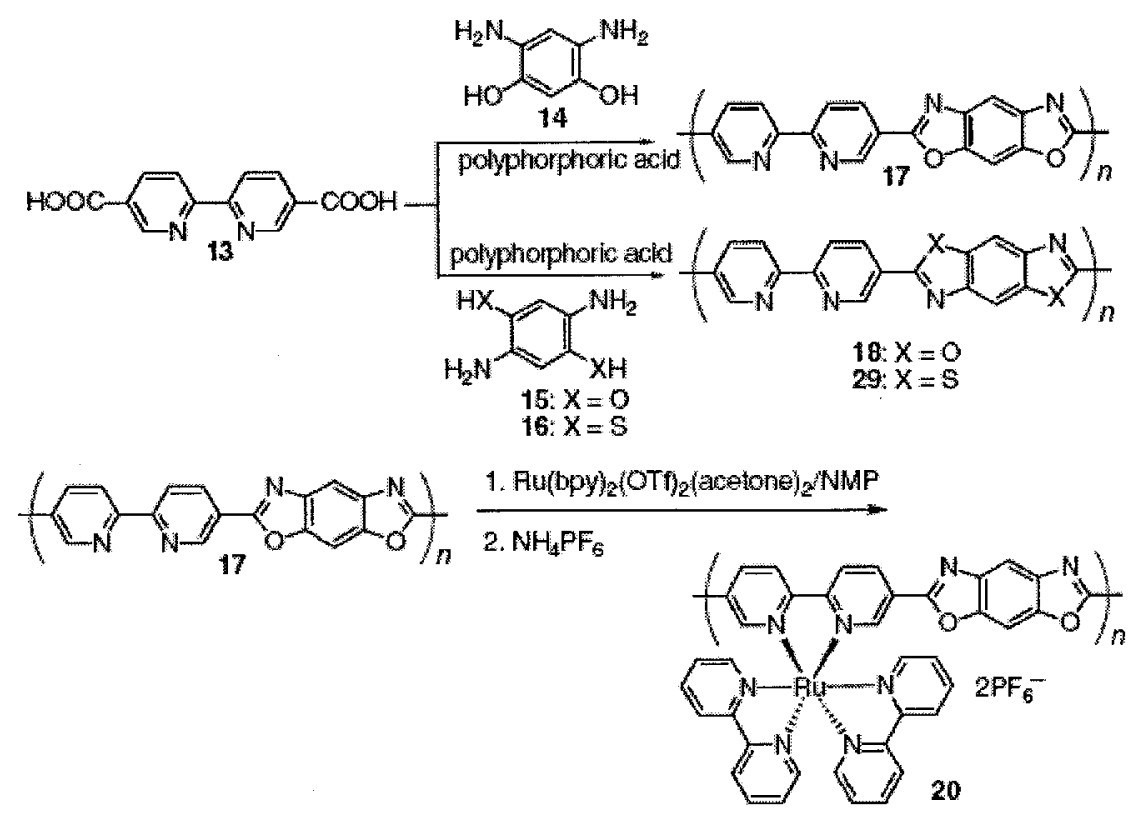

Scheme 1.4. Synthesis and metal complexation of bpy-containing poly(benzobisoxazole) and poly(benzobisthiazole) (adopted from Ref. 54).

Metal complexes have also been incorporated into the nonconjugated, rigid main chain of polymers. Examples of these polymers are shown in Figure 1.15. The synthesis of ruthenium terpyridine-containing polyimides by the reaction between the diamino-substituted ruthenium complex and a variety of aromatic dianhydrides was reported. ${ }^{55} \mathrm{~A}$ similar approach was also used in the synthesis of polyimides that contain a chlorotricarbonyl rhenium (I) diimine complex on the main chain. ${ }^{56}$ In another example, polyamides and polyesters containing a bpy ligand were synthesized by conventional condensation reactions. ${ }^{57}$ Due to the fact that all these rigid polymers can only be processed in strongly acidic or nonvolatile solvents, their uses in thin-film devices were not studied and the study in their physical properties have been mainly focused on the photosensitizing properties. 

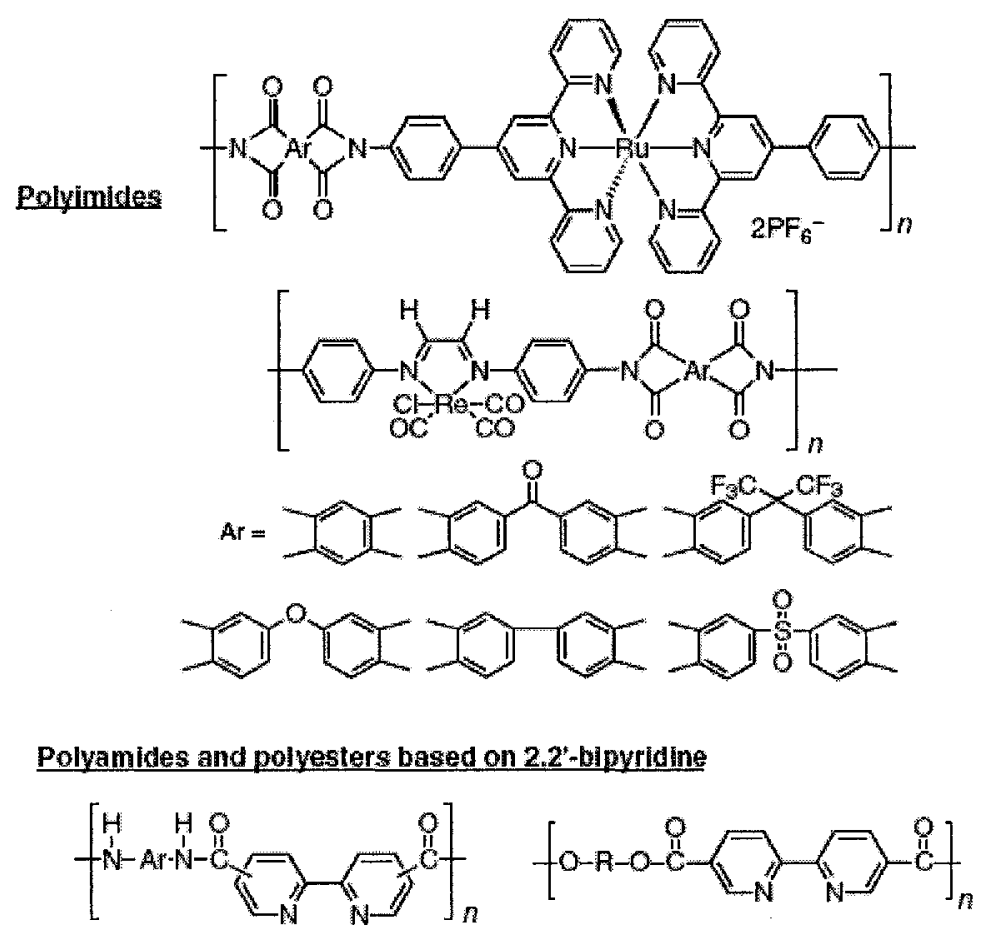

Figure 1.15. Examples of ruthenium- or rhenium-containing polyimides, polyesters, and polyamides.

\subsubsection{Conjugated polymers with pendant metal complexes}

Metal complexes can be attached to a conjugated polymer as a pendant group. It has been shown that when a pendant terpyridine was attached to a PPV main chain, the resulting polymer could potentially serve as a metal ion sensor. ${ }^{58}$ If both entities are emissive in nature and have different emission energies, it is possible to tune the resulting emission color by simply changing the relative content of these two entities.

Figure 1.16 shows a series of PPV that contain ruthenium bpy and tpy complexes on the side chain. ${ }^{59}$ Polymer 24 a contains $10 \%\left[\mathrm{Ru}(\mathrm{bpy})_{3}\right]^{2+}$ and its EL spectrum consists of independent emissions from both the main chain (560 nm) and pendant complex $(690 \mathrm{~nm})$. However, when the $\left[\mathrm{Ru}(\mathrm{bpy})_{3}\right]^{2+}$ content was increased 
to $20 \%$ (polymer $\mathbf{2 4 b}$ ), the EL was dominated by the emission from the ruthenium complex. This result suggests the presence of an energy-transfer process in which the main chain emission is quenched by the ruthenium complex. This design approach demonstrates a possibility of fine-tuning the emission color by changing the composition in a metal-containing polymer.

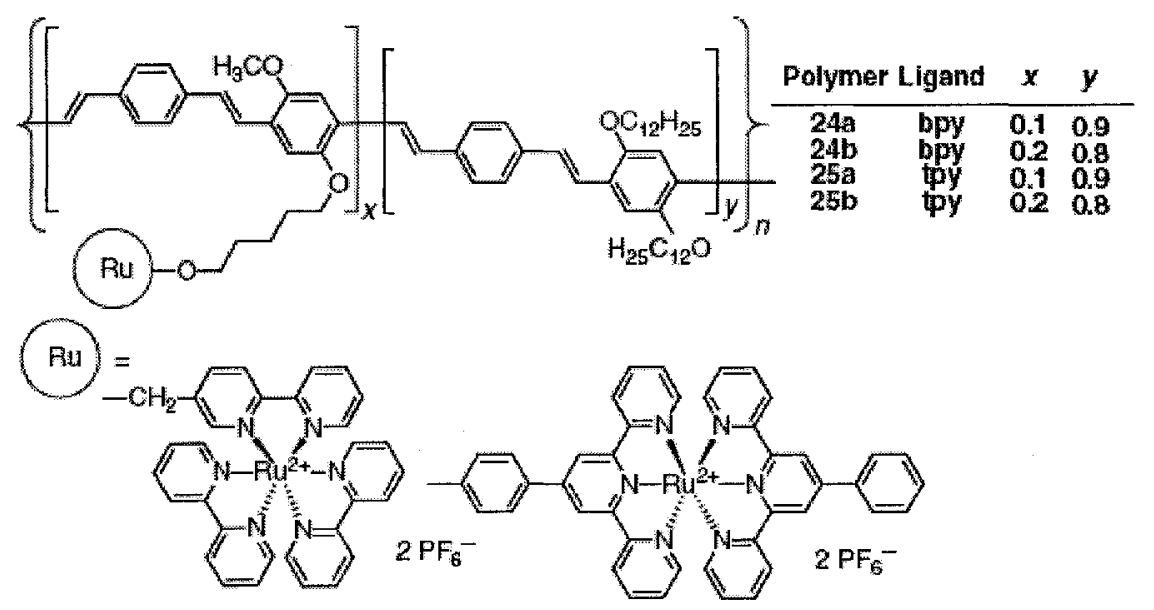

Figure 1.16. Structures of PPV incorporated with pendant ruthenium complexes (adopted from Ref. 59).

Very recently, Wang et al. reported a series of NIR electroluminescent polymers containing the pendant dinuclear DCH-ruthenium complexes. ${ }^{23}$ The EL with a maximal peak at about $790 \mathrm{~nm}$ was observed with a typical single-layer diode device (ITO/complex polymer/Au) (Figure 1.17). 


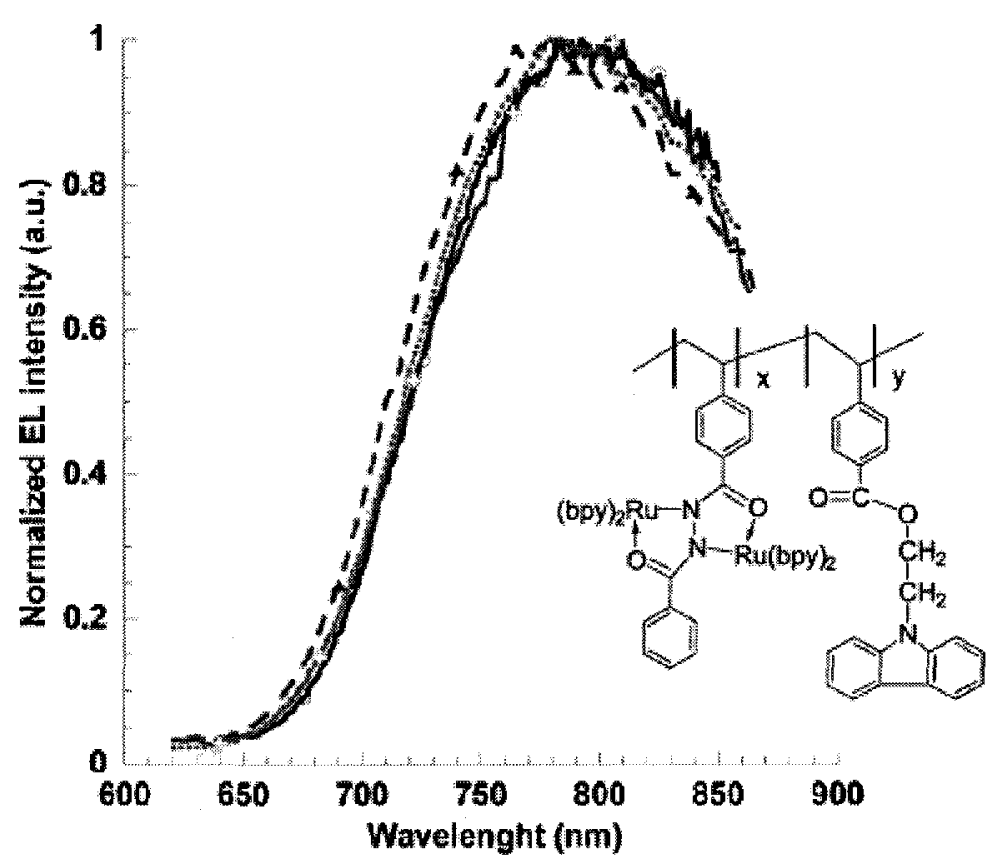

Figure 1.17. EL spectra of ruthenium complex polymers (adopted from Ref. 23).

In summary, the use of metal-containing conjugated polymers for a variety of optoelectronic applications has been demonstrated. The metal complexes can play many roles in polymers such as photosensitizers, light emitters, and charge carriers. Both hole- and electron-carrier mobilities in these polymers are enhanced due to the presence of metal complexes in the polymers. Many transition and rare earth metal complexes have unique photophysical and photochemical properties, which can be realized in the complex polymers.

\subsection{Rationale and objectives}

As discussed previously, NIR-absorbing organic materials have potential applications in photonic communication, information processing and photodynamic therapy. If the NIR absorption can be switched or turned on and off by external stimuli (e.g., electrochemical reaction, heat and light), the compounds 
and polymers are of interest as NIR electrochromic materials. Therefore, the first objective in this thesis research is to examine the relationship between the structures and photophysical and electrochemical properties of a series of DCH-Ru complexes under external stimuli, such as electrochemical redox reaction and oxidation by $\mathrm{H}_{2} \mathrm{O}_{2}$. If the DCH-Ru complexes are attached with a suitable redox-inactive dye, the fluorescence from the dye can in principle be manipulated by electrochemical means through the controlled energy transfer between the dye and the complex in a certain oxidation state.

Besides NIR electrochromism, the NIR EL is another important property that deserves investigation. The NIR light-emitting diodes based on organic materials are generally less studied because organic molecules usually have high bandgaps and emit the visible light. Therefore, it is interesting and challenging to find a class of NIR light-emitting organic materials for device applications. Some ruthenium complexes have been reported in recent years to be NIR EL active. ${ }^{60}$ Therefore, in this thesis work a new series of ruthenium complexes having different ligands are designed, aiming at tuning the bandgaps and achieving PL and EL above $1000 \mathrm{~nm}$.

Finally, to further explore the NIR active polymers, the polypyridyl ligands are to be incorporated into conjugated polymers for complexation with various metals. Accordingly, the last objective of this thesis is to design, synthesize and characterize a new series of polypyridyl-containing polymers and their metal complexes. 


\section{References}

1. M. D. Ward, J. A. McCleverty, J. Chem. Soc., Dalton Trans. 2002, 275.

2. R. J. Mortimer, N. M. Rowley, Comprehensive Coordination Chemistry II:

From Biology to Nanotechnology, J. A. McCleverty, T. J. Meyer (eds.), Oxford, Elsevier, 2003, Vol. 9, pp 581-619.

3. R. Bonnett, Comprhensive Coordination Chemistry II: From Biology to Nanotechnology, J. A. McCleverty, T. J. Meyer, (eds.), Oxord, Elsevier, 2003, vol. 9, pp. 945-1003.

4. M. K. Nazeeruddin, M. Grätzel, Comprhensive Coordination Chemistry II: From Biology to Nanotechnology, J. A. McCleverty, T. J. Meyer, (eds.), Oxord, Elsevier, 2003, vol. 9, pp. 719-758.

5. J. Keller, Military \& Aerospace Electronics, 2008, 19, 10.

6. (a) J. Fabian, H. Nakazumi, M. Matsuoka, Chem. Rev. 1992, 92, 1197. (b)

M. Emmelius, G. Pawlowski, H. W. Vollmann, Angew. Chem. Int. Ed. Engl. 1989, 28, 1445. (c) J. Fabian, R. Zahradnik, Angew. Chem. Int. Ed. Engl. $1989,28,677$.

7. (a) J. A. McCleverty, Prog. Inorg. Chem. 1968, 10, 49. (b) U. T. Mueller-Westerhoff, B. Vance, Comprehensive Coordination Chemistry, G. Wilkinson, R. D. Gillard, J. A. McClevety (eds.), Oxford, Pergamon, 1987, vol. 2, pp. 595-631.

8. U. T. Mueller-Westerhoff, B. Vance, D. I. Yoon, Tetrahedron 1991, 47, 909. 
9. (a) F. Bigoli, P. Deplano, F. A. Devillanova, V. Lippolis, P. J. Lukes, M. L. Mercuri, M. A. Pellinghelli, E. F. Trogu, J. Chem. Soc., Chem. Commun. 1995, 371. (b) F. Bigoli, P. Deplano, F. A. Devillanova, M. L. Mercuri, M. A. Pellinghelli, G. Pintus, E. F. Trogu, G. Zonneda, H. H. Wong, J. M. Williams, Inorg. Chim. Acta, 1998, 273, 175. (c) F. Bigoli, P. Deplano, F. A. Devillanova, J. R. Ferraro, V. Lippolis, P. J. Lukes, M. L. Mercuri, M. A. Pellinghelli, E. F. Trogu, J. M. Williams, Inorg. Chem. 1997, 36, 1218. (d) M. Arca, F. Demartin, F. A. Devillanova, A. Garau, F. Isaia, F. Lelj, V. Lippolis, S. Pedraglio, G. Verani, J. Chem. Soc., Dalton Trans. 1998, 3731. (e) M. C. Aragoni, M. Arca, F. Demartin, F. A. Devillanova, A. Geran, F. Isaia, F. Lelj, V. Lippolis, G. Verani, J. Am. Chem. Soc. 1999, 121, 7098. (f) F. Bigoli, P. Cassoux, P. Deplano, M. L. Mercuri, M. A. Pellinghelli, G. Pintus, A. Serpe, E. F. Trogu, J. Chem. Soc., Dalton Trans. 2000, 4639. (g) P. Deplano, M. L. Mercuri, G. Pintus, E. F. Trogu, Comments Inorg. Chem. 2001, 22, 353 .

10. (a) S.-M. Lee, M. Marcaccio, J. A. McCleverty, M. D. Ward, Chem. Mater. 1998, 10, 3272. (b) N. C. Harden, E. R. Humphrey, J. C. Jeffrey, S.-M. Lee, M. Marcaccio, J. A. McCleverty, L. H. Rees, M. D. Ward, J. Chem. Soc. Dalton Trans. 1999, 2417. (c) S. R. Bayly, E. R. Humphrey, H. de Chair, C. G. Paredes, Z. R. Bell, J. C. Jeffrey, J. A. McCleverty, M. D. Ward, F. Totti, D. Gatteschi, S. Courric, B. R. Steele, C. G. Screttas, J. Chem. Soc., Dalton Trans. 2001, 1401. (d) A. M. McDonagh, M. D. Ward, 
J. A. McCleverty, New J. Chem. 2001, 25, 1236. (e) A. M. McDonagh, S. R. Bayly, D. J. Riley, M. D. Ward, J. A. McCleverty, M.A. Cowin, C. N. Morgan, R. Verrazza, R. V. Penty, I. H. White, Chem. Mater. 2000, 12, 2523. (f) R. Kowallick, A. N. Jones, Z. R. Reeves, J. C. Jeffrey, J. A. McCleverty, M. D. Ward, New J. Chem. 1999, 23, 915.

11. M. Haga, E. S. Dodsworth, A. B. P. Lever, Inorg. Chem. 1986, 25, 447.

12. L. F. Joulié, E. Schatz, M. D. Ward, F. Weber, L. J. Yellowlees, J. Chem. Soc., Dalton Trans. 1994, 799.

13. A. M. Barthram, R. L. Cleary, R. Kowallick, M. D. Ward, Chem. Commun. $1998,2695$.

14. (a) A. M. Barthram, M. D. Ward, New J. Chem. 2000, 24, 501. (b) A. M. Barthram, R. L. Cleary, J. C. Jeffery, S. M. Couchman, M. D. Ward, Inorg. Chim. Acta. 1998, 267, 1.

15. J. García-Cañadas, A. P. Meacham, L. M. Peter, M. D. Ward, Electrochem. Commun. 2003, 5, 416.

16. C. Creutz, H. Taube, J. Am. Chem. Soc. 1973, 95, 1086.

17. (a) C. Creutz, H. Taube, J. Am. Chem. Soc. 1969, 91, 3988. (b) H. Taube, Angew. Chem. 1984, 96, 315. (c) H. Taube, Angew. Chem. 1984, 96, 329.

18. K. V. Mikkelson, M. A. Ranter, Chem. Rev. 1987, 87, 113.

19. (a) R. A. Marcus, N. Sutin, Biochim. Biophys. Acta 1985, 811, 265. (b) R. D. Cannon, Electron Transfer Reactions; Butterworths: Boston, 1980.

20. (a) V. Kasack, W. Kaim, H. Binder, J. Jordanov, E. Roth, Inorg. Chem. 
1995, 34, 1924. (b) W. Kaim, V. Kasack, H. Binder, E. Roth, J. Jordanov, Angew. Chem., Int. Ed. Engl. 1988, 27, 1174. (c) W. Kaim, V. Kasack, Inorg. Chem. 1990, 29, 4696.

21. (a) Y. Qi, P. Desjardins, Z. Y. Wang, J. Opt. A: Pure Appl. Opt. 2002, 4, S273. (b) Y. Qi, P. Desjardins, X. S. Meng, Z. Y. Wang, Opt. Mater. 2003, 21, 255. (c) Y. Qi, Z. Y. Wang, Macromolecules 2003, 36, 3146. (d) Z. Y. Wang, J. Zhang, X. Wu, M. Birau, G. Yu, H. Yu, Y. Qi, P. Desjardins, X. S. Meng, J. P. Gao, E. Todd, N. H. Song, Y. W. Bai, A. M. R. Beaudin, G. LeClair, Pure Appl. Chem. 2004, 76, 1435. (e) M. F. Rastegar, E. K. Todd, H. Tang, Z. Y. Wang, Org. Lett. 2004, 6, 4519. (f) S. Xun, G. LeClair, J. Zhang, X. Chen, J. P. Gao, Z. Y. Wang, Org. Lett. 2006, 8, 1697.

22. (a) R. H. Laye, S. M. Couchman, M. D. Ward, Inorg. Chem. 2001, 40, 4089. (b) V. Kasack, W. Kaim, H. Binder, J. Jordanov, E. Roth, Inorg. Chem. 1995, 34, 1924. (c) R. C. Rocha, H. E. Toma, Can. J. Chem. 2001, 79, 145. (d) P. J. Mosher, G. P. A. Yap, R. J. Crutchley, Inorg. Chem. 2001, $40,1189$.

23. S. Wang, X. Li, S. Xun, X. Wan, Z. Y. Wang, Macromolecules 2006, 39, 7502.

24. (a) M. Pope, H. Kallmann, P. Magnante, J. Chem. Phys. 1963, 38, 2042. (b) W. Helfrich, W. G. Schneider, Phys. Rev. Lett. 1965, 14, 229.

25. C. W. Tang, S. A. Van Slyke, Appl. Phys. Lett. 1987, 51, 913.

26. J. H. Burroughes, D. D. C. Bradley, A. R. Brown, R. N. Marks, K. 
MacKay, R. H. Friend, P. L. Burn, A. B. Holmes, Nature 1990, 347, 539.

27. (a) H. Suzuki, Appl. Phys. Lett. 2000, 76, 1543. (b) M. Casalboni, F. De Matteis, P. Prosposito, R. Pizzoferrato, Appl. Phys. Lett. 1999, 75, 2172.

(c) H. Suzuki, Appl. Phys. Lett. 2002, 80, 3256. (d) H. Suzuki, Thin Solid Films, 2001, 393, 352. (e) E. I. Mal'tsev, D. A. Lypenko, V. V. Bobinkin, B. I. Shapiro, A. R. Tameev, A. I. Tolmachev, Yu. L. Slominskii, M. A. Brusentseva, S. V. Kirillov, H. F. M. Schoo, A. V. Vannikov, Russ. J. Electrochem. 2004, 40, 245.

28. (a) W. P. Gillin, R. J. Curry, Appl. Phys. Lett. 1999, 74, 798. (b) R. J. Curry, W. P. Gillin, Appl. Phys. Lett. 1999, 75, 1380. (c) O. M. Khreis, R. J. Curry, M. Somerton, W. P. Gillin, J. Appl. Phys. 2000, 88, 777. (d) Z. Hong, C. Liang, R. Li, F. Zang, D. Fan, W. Li, L. S. Hung, S. T. Lee, Appl. Phys. Lett. 2001, 79, 1942. (e) Y. Kawamura, Y. Wada, Y. Hasegawa, M. Iwamuro, T. Kitamura, S. Yanagida, Appl. Phys. Lett. 1999, 74, 3245. (f) F. X. Zang, Z. R. Hong, W. L. Li, M. T. Li, X. Y. Sun, Appl. Phys. Lett. 2004, 84, 2679. (g) W. Q. Zhao, P. F. Wang, G. Z. Ran, G. L. Ma, B. R. Zhang, W. M. Liu, S. K. Wu, L Dai, G. G. Qin, J. Phys. D: Appl. Phys. 2006, 39, 2711. (h) Z. R. Hong, C. J. Liang, R. G. Li, D. Zhao, D. Fan, W. L. Li, Thin Solid Films 2001, 391, 122. (i) A. Bettencourt-Dias, Dalton Trans. 2007, 2229. (j) A. O’Riordan, E. O'Connor, S. Moynihan, P. Nockemann, P. Fias, R. Van Deun, D. Cupertino, P. Mackie, G. Redmond, Thin Solid Films 2006, 497, 299. (k) B. S. Harrison, T. J. Foley, M. 
Bouguettaya, J. M. Boncella, J. R. Reynolds, K. S. Schanzea, J. Shim, P. H. Holloway, G. Padmanaban, S. Ramakrishnan Appl. Phys. Lett., 2001, 79, 3770. (1) L. H. Slooffa, A. Polman, F. Caciallib, R. H. Friend, G. A. Hebbink, F. C. J. M. van Veggel, D. N. Reinhoudt, Appl. Phys. Lett. 2001, 78, 2122 (m) K. S. Schanze, J. R. Reynolds, J. M. Boncella, B. S. Harrison, T. J. Foly, M. Bouguettaya, T.-S. Kang, Synth. Met. 2003, 137, 1013. (n) B. S. Harrison, T. J. Foley, A. S. Knefely, J. K. Mwaura, G. B. Cunningham, T.-S. Kang, M. Bouguettaya, J. M. Boncella, J. R. Reynolds, K. S. Schanze, Chem. Mater. 2004, 16, 2938. (o) J. H. Kim, P. H. Holloway, Adv. Mater. 2005, 17, 91. (p) T.-S. Kang, B. S. Harrison, T. J. Foley, A. S. Knetely, J. M. Boncella, J. R. Reynolds, K. S. Schanze, Adv. Mater. 2003, 15, 1093. (q) T.-S. Kang, B. S. Harrison, T. J. Foley, M. Bouguettaya, J. M. Boncella, K. S. Schanze, J. R. Reynolds, Adv. Mater. 2003, 13, 205. (r) E. L. Williams, J. Li, G. E. Jabboura, Appl. Phys. Lett. 2006, 89, 083506 (s) C. Yi, C.-J. Yang, J. Liu, M. Xu, J.-H. Wang, Q.-Y. Cao, X.-C. Gao, Inorganica Chimica Acta 2007, 360, 3493. (t) F. X. Zang, W. L. Li, Z. R. Hong, H. Z.Wei, M. T. Li, X. Y. Sun, C. S. Lee, Appl. Phys. Lett. 2004, 84, 5115.

29. (a) Y. Zhang, J. Yang, Q. Hou, Y. Mo, J. Peng, Y. Cao, Chin. Sci. Bull. 2005, 50 , 957. (b) R. Yang, R. Tian, J. Yan, Y. Zhang, J. Yang, Q. Hou, W. Yang, C. Zhang, Y. Cao, Macromolecules 2005, 38, 244. (c) X. Li, W. Zeng, Y. Zhang, Q. Hou, W. Yang, Y. Cao, Eur. Polym. J. 2005, 41, 2923. (d) M. R. Andersson, M. Berggren, O. Inganas, G. Gustafsson, J. C. 
Carlberg, D. Selse, T. Hjertberg, O. Wennerstrom, Macromolecules, 1995, 28, 7525. (e) M. Chen, E. Perzon, M. R. Andersson, S. Marcinkevicius, S. K. M. Jönsson, M. Fahlman, M. Berggren, Appl. Phys. Lett, 2004, 84, 3570. (f) B. C. Thompson, L. G. Madrigal, R. Pinto, T. S. kang, S. Schanze, R. Reynolds, J. Polym. Sci. Part A: Polym. Chem. 2005, 43, 1417. (g) Y. Xia, J. Luo, X. Deng, X. Li, D. Li, X. Zhu, W. Yang, Y. Cao, Macromol. Chem. Phys. 2006, 207, 511.

30. (a) R. E. Whan, G. A. Crosby, J. Mol. Spectrosc. 1962, 8, 315. (b) K. M. L. Bhaumi, M. A. El-Sayed, J. Chem. Phys. 1965, 42, 787.

31. R. G. Sun, Y. Z. Wang, Q. B. Aheng, H. J. Zheng, A. J. Epstein, J. Appl. Phys. 2000, 87, 7589 .

32. Y. Kawamura, Y. Wada, S. Yanagida, Jpn. J. Appl. Phys., Part 1, 2001, 40,350 .

33. D. R. Baigent, P. J. Hamer, R. H. Friend, S. C. Moratti and A. B. Holmes, Synth. Met. 1995, 71, 2175.

34. S. Destri, W. Porzio, F. Meinardi, R. Tubino and G. Salerno, Macromolecules, 2003, 36, 273.

35. M. Casalboni, F. D. Matteis, P. Prosposito, R. Pizzoferrato, Appl. Phys. Lett. 1999, 75, 2172.

36. G. Brocks, A. Tol, J. Phys. Chem. 1996, 100, 1838.

37. (a) R. P. Kingsborough, T. M. Swager, Prog. Inorg. Chem. 1999, 48, 123.

(b) A. S. Abd-El-Aziz, Macromol. Rapid Commun. 2002, 23, 995. 
38. F. Ciardelli, E. Tsuchida, D. Wöhrle, Macromolecule-Metal Complexes, Springer, Berlin, 1996.

39. (a) T. Yamamoto, T. Maruyama, Z. H. Zhou, T. Ito, T. Fukura, Y. Yoneda, F. Begum, T. Ikeda, S. Sasaki, H. Takezoe, A. Fukuda, K. Kubota, J. Am. Chem. Soc. 1994, 116, 4832. (b) S. C. Rasmussen, D. W. Thompson, V. Singh, J. D. Petersen, Inorg. Chem. 1996, 35, 3449. (c) L. Trouillet, A. De Nicola, S. Guillerez, Chem. Mater. 2000, 12, 1611. (d) C. Kaes, A. Katz, M. W. Hosseini, Chem. Rev. 2000, 100, 3553. (e) K. A. Walters, K. D. Ley, C. S. P. Cavalaheiro, S. E. Miller, D. Gosztola, M. R. Wasielewski, A. P. Bussandri, H. van Willigen, K. S. Schanze, J. Am. Chem. Soc. 2001, 123,8329 .

40. B. Wang, M. R. Wasielewski, J. Am. Chem. Soc. 1997, 119, 12

41. U. Velten, M. Rehahn, Macromol. Chem. Phys. 1998, 199, 127.

42. C. G. Cameron, P. G. Pickup, Chem. Commun. 1997, 303.

43. S. Kelch, M. Rehahn, Macromolecules 1997, 30, 6185.

44. B. Jiang, S. W. Yang, S. L. Bailey, L. G. Hermans, R. A. Niver, M. A. Bolcar, W. E. Jones Jr., Coord. Chem. Rev. 1998, 171, 365.

45. W. Y. Ng, W. K. Chan, Adv. Mater. 1997, 9, 716.

46. W. K. Chan, X. Gong, W. Y. Ng, Appl. Phys. Lett. 1997, 71, 2919.

47. W. K. Chan, P. K. Ng, X. Gong, S. Hou, J. Mater. Chem. 1998, 9, 2103.

48. P. K. Ng, X. Gong, S. H. Chan, L. S. M. Lam, W. K. Chan, Chem. Eur. J. $2001,7,4358$. 
49. Schulz, M. Bruma, L. Brehmer, Adv. Mater. 1997, 9, 601.

50. (a) Q. Pei, Y. Yang, Adv. Mater. 1995, 7, 559. (b) E. Buchwald, M. Meier, S. Karg, P. Pösch, H.-W. Schmidt, P. Strohriegl, W. Rieß, M. Schwoerer, Adv. Mater. 1995, 7, 839. (c) Z. Peng, Z. Bao, M. E. Galvin, Adv. Mater. 1998, 10, 680. (d) S. Yin, J. Peng, Huang, W. X. Liu, W. Li, B. He, Synth. Met. 1998, 93, 193.

51. X. Gong, P. K. Ng, W. K. Chan, Adv. Mater. 1998, 10, 1337.

52. W. K. Chan, P. K. Ng, X. Gong, S. Hou, Appl. Phys. Lett. 1999, 75, 3920.

53. T. Yasuda, I. Yamaguchi, T. Yamamoto, Adv. Mater. 2003, 15, 293.

54. S. C. Yu, X. Gong, W. K. Chan, Macromolecules 1998, 31, 5639.

55. W. Y. Ng, X. Gong, W. K. Chan, Chem. Mater. 1999, 11, 1165.

56. L. S. M. Lam, S. H. Chan, W. K. Chan, Macromol. Rapid Commun. 2000, 21,1081 .

57. S. C. Yu, S. Hou, W. K. Chan, Macromolecules 2000, 33, 3259.

58. M. Kimura, T. Horai, K. Hanabusa, H. Shirai, Adv. Mater. 1998, 10, 459.

59. C. T. Wong, W. K. Chan, Adv. Mater. 1998, 11, 455.

60. (a) S. M. Molnar, K. R. Neville, G. E. Jensen, K. J. Brewer, Inorg. Chim. Acta. 1993, 206, 69. (b) R. R. Ruminski, P. T. Deere, M. Olive, D. Serveiss, Inorg. Chim. Acta. 1998, 281, 1. (c) J. A. Treadway, G. F. Strouse, R. R. Ruminski, T. J. Meyer, Inorg. Chem. 2001, 40, 4508. (d) T. Renouard, R.-A. Fallahpour, M. K. Nazeeruddin, R. Humphry-Baker, S. I. Gorelsky, A. B. P. Lever, M. Grätzel, Inorg. Chem. 2002, 41, 367. (e) P. F. H. 
Schwab, S. Diegoli, M. Biancardo, C. A. Bignozzi, Inorg. Chem. 2003, 42, 6613. (f) H. Sugihara, S. Sano, T. Yamaguchi, M. Yanagida, T. Sato, Y. Abe, Y. Nagao, H. Arakawa, J. Photochem. Photobiol. A. 2004, 166, 81. 


\section{Chapter 2 Design, Synthesis, and Stimulus-Responsive Properties of Ruthenium Complexes}

\subsection{Introduction}

In this chapter, four dinuclear ruthenium complexes with 1,2-dicarbonylhydrazido ligands (DCH-Ru complexes) and different $\mathrm{R}$ and $\mathrm{R}^{\prime}$ groups are designed (Figure 2.1). The complexes were prepared and characterized for their spectroscopic and electrochemical properties.

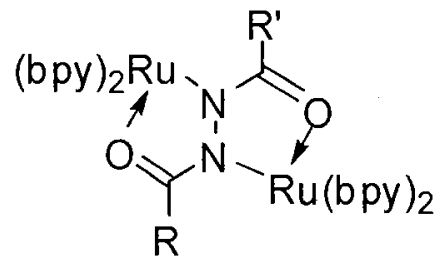

\begin{tabular}{ccc}
\hline DCH-Ru & R & R' $^{\prime}$ \\
\hline 2.1 & NHPr & NHPr \\
2.2 & NHPr & OEt \\
2.3 & OEt & OEt \\
2.4 & Ph & Ph \\
\hline
\end{tabular}

Figure 2.1. General structure of dinuclear DCH-Ru complexes.

The DCH-Ru complexes are electrochromic and display different absorption spectra at each of the three oxidation states. Oxidation to the mixed-valence state $\left(\mathrm{Ru}^{\mathrm{II}} / \mathrm{Ru}{ }^{\mathrm{III}}\right)$ can be done with various oxidizing agents, such as hydrogen peroxide $\left(\mathrm{H}_{2} \mathrm{O}_{2}\right)$ and its analogues, thus DCH-Ru complexes could be used to detect these peroxide compounds by monitoring the absorbance of the complex in the $\mathrm{Ru}^{\mathrm{Il}} / \mathrm{Ru}{ }^{\mathrm{III}}$ state. 
Moreover, two anionic dyes are chosen as counterions for DCH-Ru complexes. The dependence of dye's PL emission on the oxidation states of DCH-Ru complexes, due to the energy transfer (ET) between complexes and dyes, will be studied. Thus, the PL emission of dyes can be switched on and off in a typical electrochemical cell.

\subsection{Synthesis and characterization of DCH-Ru complexes}

The synthesis of ligands L1-L4 and the corresponding dinuclear ruthenium complexes is depicted in Scheme 2.1. All four ligands were synthesized by reaction of acyl chloride, chloroformate or isocyanate with the corresponding hydrazide or hydrazine as reported. ${ }^{1}$ The DCH-Ru complexes were prepared by exchange with $\mathrm{Ru}(\mathrm{bpy})_{2} \mathrm{Cl}_{2}$ as previously reported. ${ }^{2}$ Complexes $2.1-\mathrm{IR} 125$ and 2.4-SRB were prepared by adding an excess of IR125 and SRB to complex 2.1 and complex 2.4 (counterion of $\mathrm{Cl}^{-}$) in aqueous solution, respectively. 


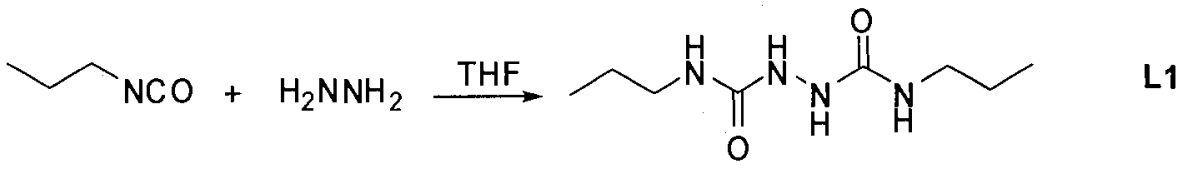

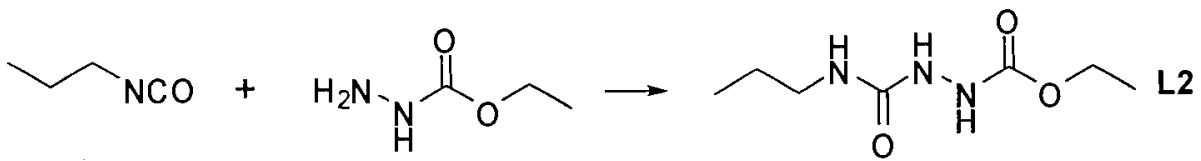

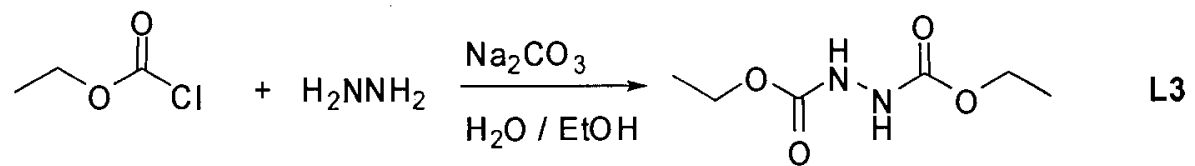

$$
\begin{aligned}
& \mathrm{Cl}_{\mathrm{Cl}}^{\mathrm{O}}+\underset{\mathrm{HN}-\mathrm{NH}_{2}}{\mathrm{Ph}} \frac{\mathrm{Na}_{2} \mathrm{CO}_{3}}{\mathrm{H}_{2} \mathrm{O} / \mathrm{THF}}
\end{aligned}
$$

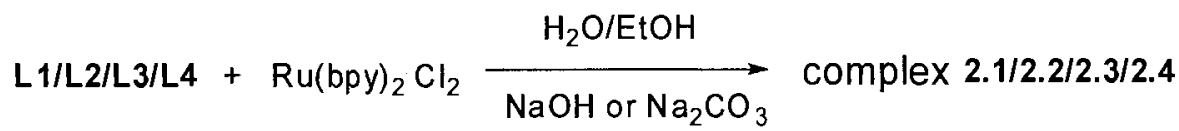

Scheme 2.1. Synthesis of complexes 2.1-2.4 and corresponding ligands.

The structures of ligand L1-L4 were confirmed by ${ }^{1} \mathrm{H} N M R,{ }^{13} \mathrm{C}$ NMR and EI-MS. Taking into account of a small residue of oxidized paramagnetic complexes, it is impossible to make complete NMR assignments. The structural characterization of complexes is generally performed by a combination of spectroscopic methods, including UV-vis-NIR, cyclic voltammetry (CV) and mass spectrometry (MS). Among these methods, ESI-MS is one of the important analytical methods applied to the structural determination of complexes.

Figure 2.2 shows the MS spectrum of complex 2.1, which exhibits two diagnostic fragmentation ion peaks at $m / z 1173$ and 514 . The calculated molecular mass of complex 2.1 is 1317. A loss of $2 \mathrm{PF}_{6}{ }^{-}$anions gives a molecular ion peak at $m / z 514\left[\mathrm{M}-2 \mathrm{PF}_{6}^{-}\right]^{+}(100 \%)$. Another structurally informative fragment at $\mathrm{m} / \mathrm{z}$ 
$1173\left[\mathrm{M}-\mathrm{PF}_{6}^{-}\right]^{+}(6 \%)$ is observed. Similar ESI-MS data were obtained for complexes 2.2-2.4.

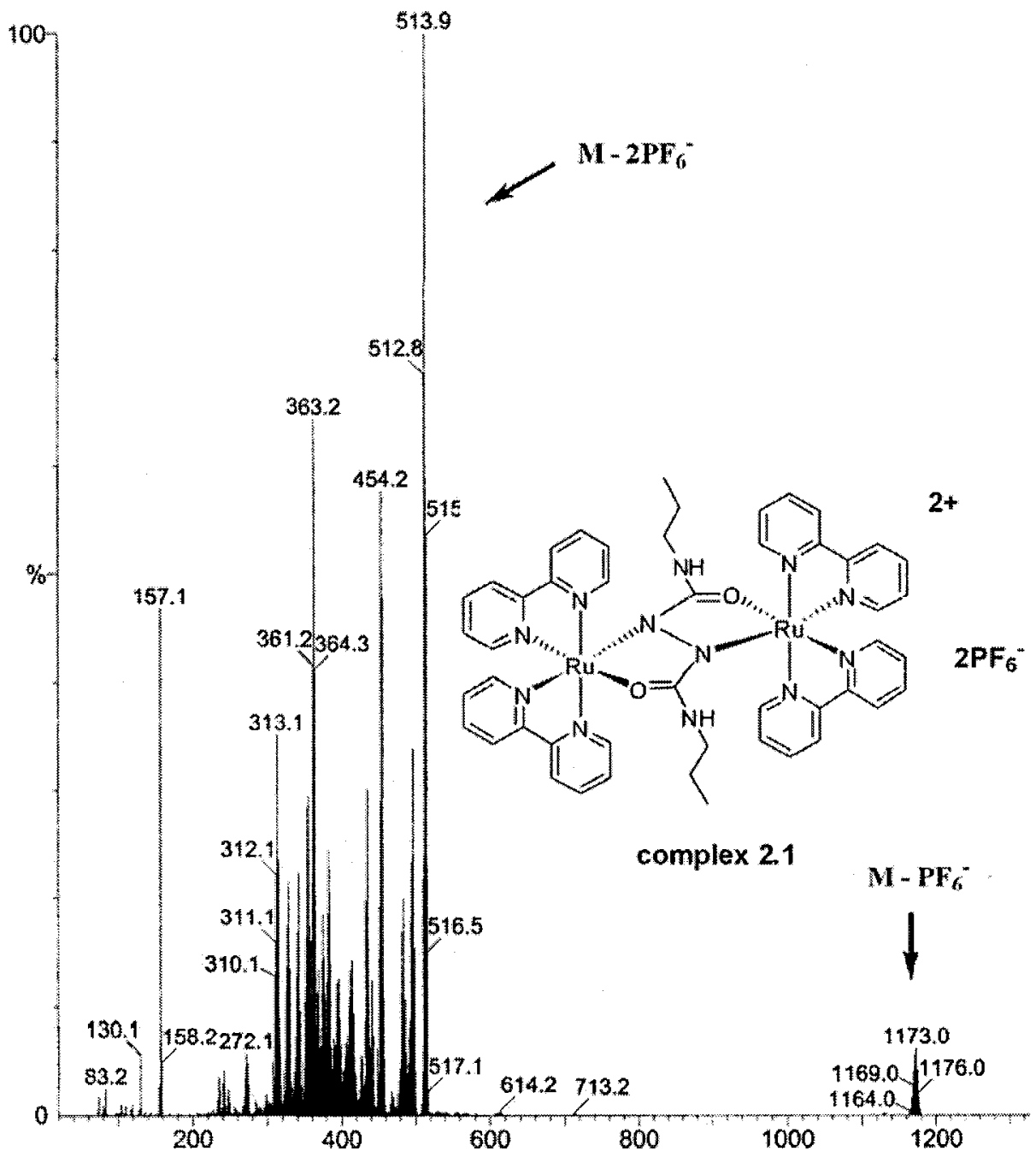

Figure 2.2. Mass spectrum of complex 2.1.

Cyclic voltammetry was used to characterize the electrochemical properties of complexes. Figure 2.3 shows typical $\mathrm{CV}$ graphs of DCH-Ru complexes in solution and in film. All the complexes exhibit two reversible oxidation waves. The first oxidation represents the process of $\mathrm{Ru}^{\mathrm{II}}-\mathrm{DCH}-\mathrm{Ru}^{\mathrm{II}} \leftrightarrow$ 
$\mathrm{Ru}^{\mathrm{II}}-\mathrm{DCH}-\mathrm{Ru} \mathrm{u}^{\mathrm{III}}$, and the second is assigned as $\mathrm{Ru} \mathrm{u}^{\mathrm{II}}-\mathrm{DCH}-\mathrm{Ru}^{\mathrm{III}} \leftrightarrow \mathrm{Ru}^{\mathrm{III}}-\mathrm{DCH}-\mathrm{Ru} \mathrm{u}^{\mathrm{III}}$.

The electrochemical and spectroscopic data for complexes 2.1-2.4 are given in Table 2.1.

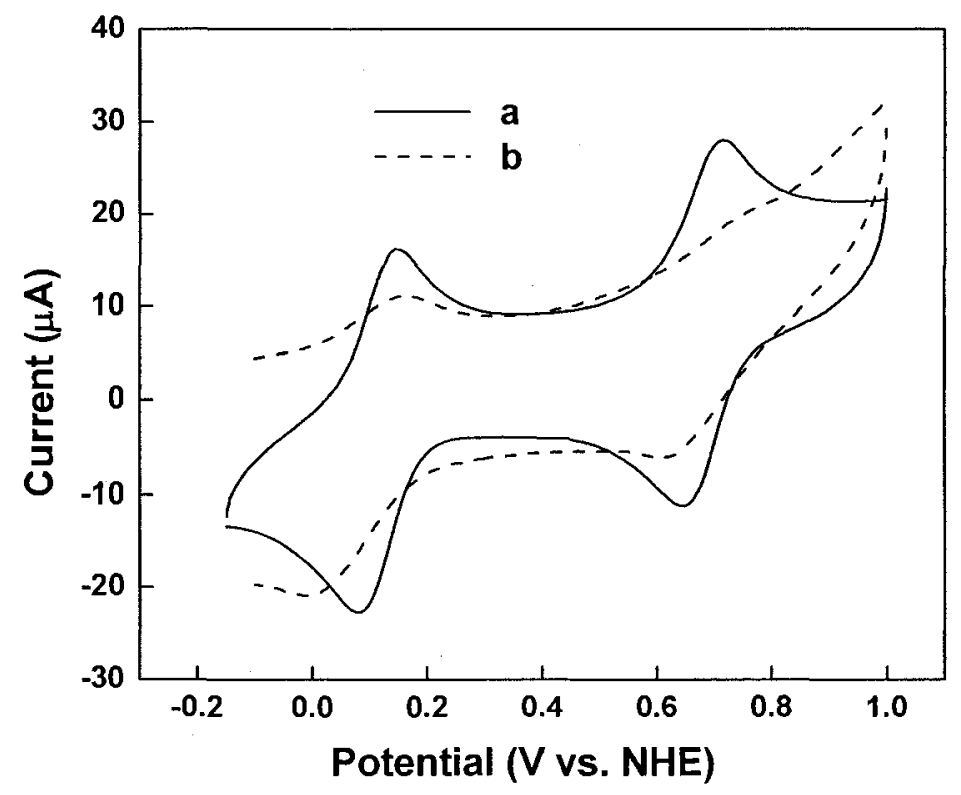

Figure 2.3. $\mathrm{CV}$ of complex 2.1 (a) in $0.1 \mathrm{M} \mathrm{NEt}_{4} \mathrm{ClO}_{4} / \mathrm{CH}_{3} \mathrm{CN}$ and (b) as a film on indium tin oxide coated glass, at a scan rate of $100 \mathrm{mVs}^{-1}$.

To correlate the substituent effect with the spectroscopic and electrochemical data, the Hammett parameters $\left(\sigma^{*}\right)$ as a direct measure of electron donor potentials were used. ${ }^{3}$ The Hammett parameters are calculated from:

$$
\sigma^{*}=\sigma_{P}{ }^{l}+\sigma_{P}^{2} \quad \sigma_{P}=\sigma_{l}+\sigma_{R}
$$

where $\sigma_{P}{ }^{1}$ and $\sigma_{P}{ }^{2}$ are the Hammett parameters of the substituents $\mathrm{R}$ and $\mathrm{R}^{\prime}$ respectively. $\sigma_{I}$ is an inductive parameter. $\sigma_{R}$ is the resonance effect parameter.

Figure 2.4 shows the correlation between the total $\sigma^{*}$ of the two substituents and the first $\left({ }^{1} E_{1 / 2}\right)$ and second oxidation potentials $\left({ }^{2} E_{1 / 2}\right)$ of the complexes. The plot clearly shows a linear dependence of electrochemical properties of $\mathrm{DCH}-\mathrm{Ru}$ 
complexes on the Hammett parameters. As the donor strength of the substituent increases, there is a shift of both the first $\left({ }^{1} E_{1 / 2}\right)$ and second oxidation potentials $\left({ }^{2} E_{1 / 2}\right)$ to lower values, which can be attributed to the decrease of the stability of the ruthenium d-orbitals as the ligand is a strong $\sigma$-donor. ${ }^{2 a}$ Compared with complex 2.4, ${ }^{1} E_{1 / 2}$ and ${ }^{2} E_{1 / 2}$ of complex 2.1 with the strong electron-donating NHPr group decreased from 500 to $50 \mathrm{mV}$ and 1100 to $580 \mathrm{mV}$, respectively. Since the influences of two substituents on the two metal centers are nearly equal, the differences between two oxidation potentials $(\Delta E)$ are not significantly affected. The only effect on $\Delta E$ is a slight drop over the series with increasing donor strength.

Table 2.1. Electrochemical data, Hammett substituent parameters and MMCT band energies for DCH-Ru complexes.

\begin{tabular}{ccccccc}
\hline Complex & ${ }^{1} \mathrm{E}_{1 / 2}{ }^{\mathrm{a}}$ & ${ }^{2} \mathrm{E}_{1 / 2}{ }^{\mathrm{a}}$ & $\Delta \mathrm{E}^{\mathrm{b}}$ & $\sigma^{*}$ & $\lambda_{\max }{ }^{\mathrm{c}}(\log \varepsilon)^{\mathrm{d}}$ & $\mathrm{Eg}^{\mathrm{e}}$ \\
\hline $\mathbf{2 . 1}$ & 50 & 580 & 530 & -1.10 & $1150(3.43)$ & 0.8352 \\
$\mathbf{2 . 2}$ & 160 & 700 & 540 & -0.79 & $1270(3.47)$ & 0.7133 \\
$\mathbf{2 . 3}$ & 240 & 800 & 560 & -0.48 & $1410(3.78)$ & 0.6889 \\
$\mathbf{2 . 4}$ & 500 & 1100 & 600 & -0.02 & $1600(4.13)$ & 0.6448 \\
\hline
\end{tabular}

a Cyclic voltammetry performed at a scan rate of $100 \mathrm{mVs}^{-1}$ in $0.1 \mathrm{M}$ $\mathrm{NEt}_{4} \mathrm{ClO}_{4} / \mathrm{CH}_{3} \mathrm{CN}$. Potentials $E$ in $\mathrm{mV}$ vs NHE. ${ }^{\mathrm{b}} \Delta E={ }^{2} E_{1 / 2}-{ }^{1} E_{1 / 2}$ in $\mathrm{mV}$. ${ }^{\mathrm{c}}$ for the $\mathrm{Ru}^{\mathrm{II}} / \mathrm{Ru}^{\mathrm{III}}$ state of complexes in $\mathrm{nm}{ }^{\mathrm{d}}$ molar extinction coefficients $\varepsilon$ in $\mathrm{M}^{-1} \mathrm{~cm}^{-1}$. MMCT band energies in eV. 


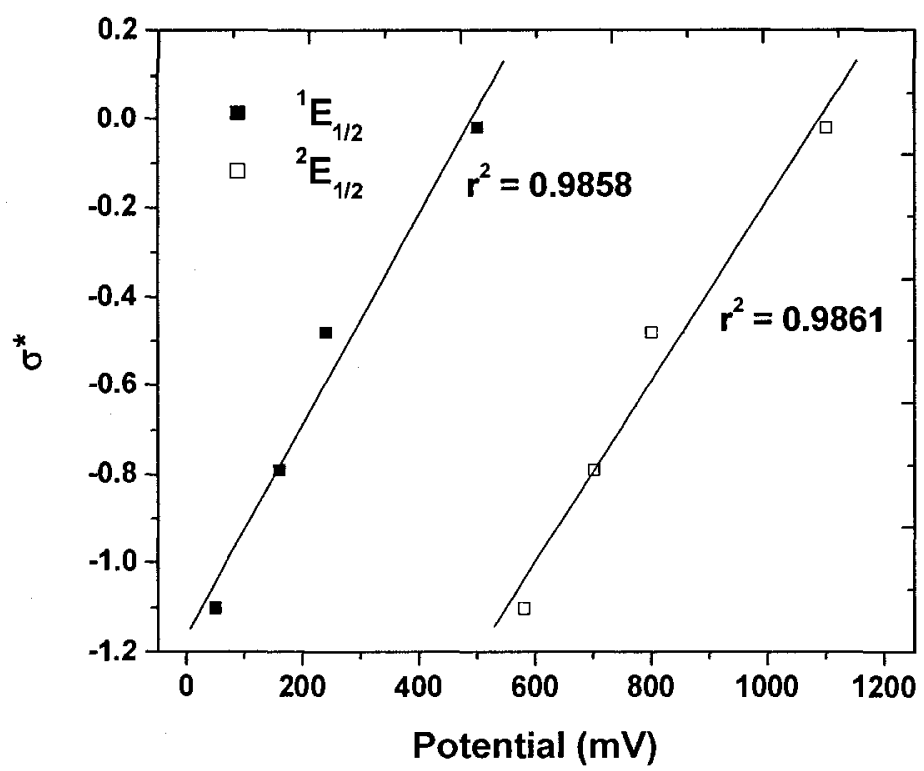

Figure 2.4. Hammett parameter versus $E_{1 / 2}$ for complexes 2.1-2.4.

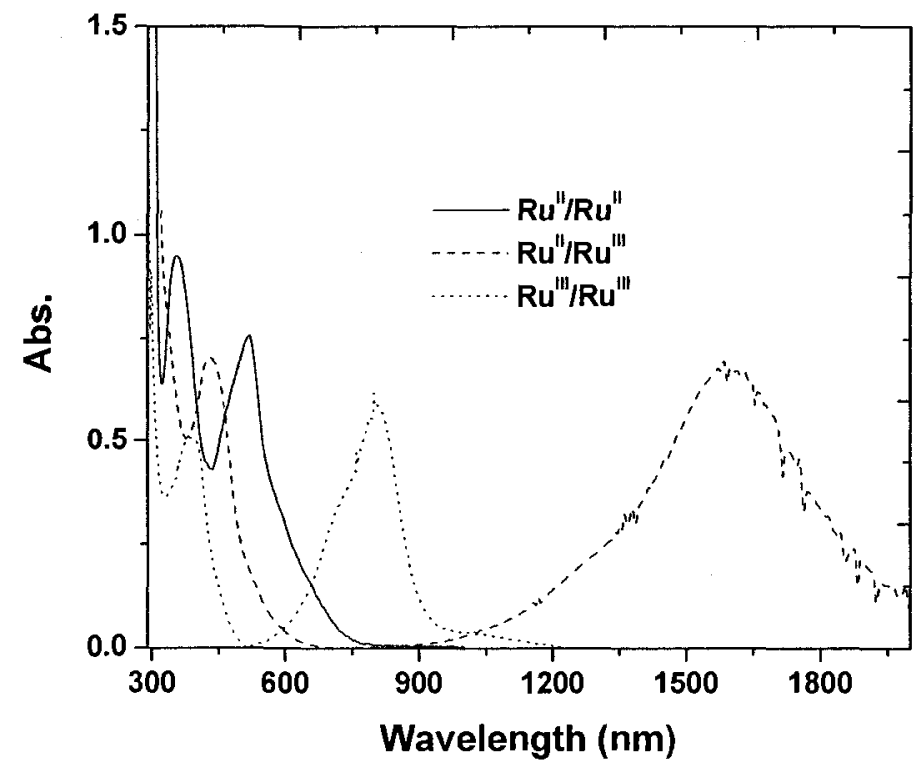

Figure 2.5. UV-vis-NIR spectra of complex 2.4 in three oxidation states.

DCH-Ru complexes possess three oxidation states, which give rise to the different absorption spectra. Figure 2.5 shows the absorption spectra of complex 2.4 in three oxidation states. Complexes 2.4 in the $\mathrm{Ru}^{\mathrm{Il}} / \mathrm{Ru}^{\mathrm{II}}$ state display two 
intense absorptions around at 350 and $515 \mathrm{~nm}$ associated with the MLCT transition (metal-to-ligand charge transfer). Oxidation to the $\mathrm{Ru}^{\mathrm{II}} / \mathrm{Ru}^{\mathrm{III}}$ state results in the appearance of a strong and broad intervalence transition band centered at $1590 \mathrm{~nm}$. These bands are attributed to the MMCT transition (metal-metal charge transfer) formed in the mixed-valence state. Upon further oxidation to the $\mathrm{Ru}^{\mathrm{III}} / \mathrm{Ru} \mathrm{ul}^{\mathrm{III}}$ state, a new band at $800 \mathrm{~nm}$ appears, which is assigned to a ligand-to-metal charge-transfer (LMCT) transition.

As expected, the substituents affect the absorption properties of these complexes significantly. Figure 2.6 shows intense NIR absorption bands of four DCH-Ru complexes in the $\mathrm{Ru}^{\mathrm{II}} / \mathrm{Ru}^{\mathrm{III}}$ state. The MMCT band is blue shifted upon increasing the donor strength of the substituents. With a strong electron-donating NHPr group, complex 2.1 has the lowest MMCT band at $1150 \mathrm{~nm}$. Overall, electron-withdrawing or electron-donating ability of the substituents can affect the electronic states of the coordinating sites ( $\mathrm{N}$ and $\mathrm{O}$ atoms), which in turn influences the spectroscopic and electrochemical properties of the complexes. 


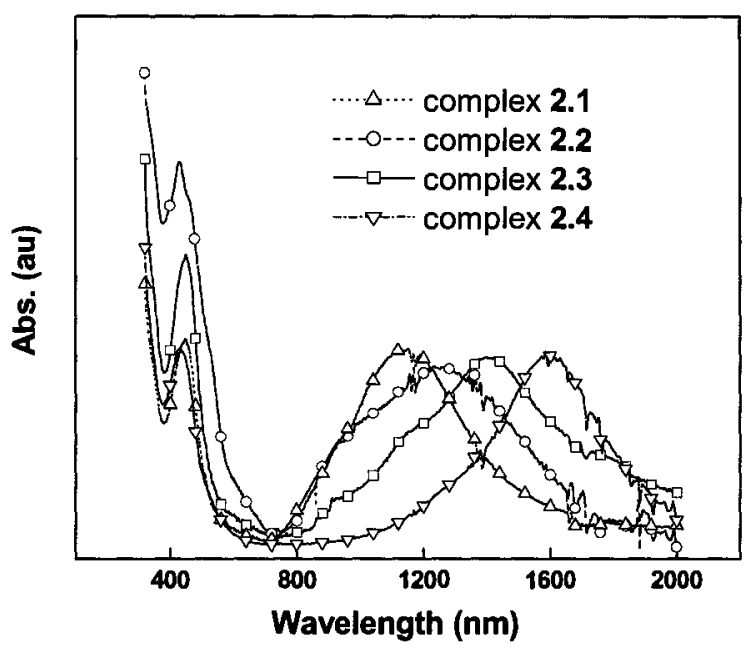

Figure 2.6. Absorption spectra of complexes in the $\mathrm{Ru}^{\mathrm{II}} / \mathrm{Ru}{ }^{\mathrm{III}}$ state in $0.1 \mathrm{M}$ $\mathrm{NEt}_{4} \mathrm{ClO}_{4} / \mathrm{CH}_{3} \mathrm{CN}$ obtained using an optically transparent thin-layer electrochemical cell.

\section{$2.4 \quad \mathrm{H}_{2} \mathrm{O}_{2}$-responsive NIR properties}

Since $\mathrm{H}_{2} \mathrm{O}_{2}$ could oxidize the ruthenium complex to its $\mathrm{Ru} / \mathrm{Ru} \mathrm{u}^{\mathrm{III}}$ state and NIR absorbance of the complex could be monitored, DCH-Ru complexes can be used to detect $\mathrm{H}_{2} \mathrm{O}_{2}$ (Scheme 2.2). Furthermore, the complex changes colour from purple to yellow, although this visual effect is slow to appear to the naked eye.

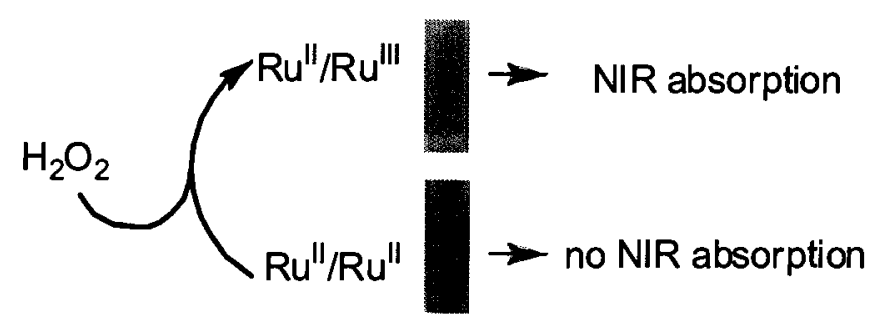

Scheme 2.2. Detection of $\mathrm{H}_{2} \mathrm{O}_{2}$. Cuvettes shown are acetonitrile solutions of the complex in their respective oxidation states. 
A test was first carried out in solution using $\mathrm{H}_{2} \mathrm{O}_{2}$ directly. To complex $\mathbf{2 . 1}$ in acetonitrile $\left(1 \times 10^{-4} \mathrm{M}\right)$ in a cuvette, $\mathrm{H}_{2} \mathrm{O}_{2}$ with the given concentration up to $10 \mathrm{mM}$ was introduced. The absorbance was monitored at $1150 \mathrm{~nm}$ and recorded at different time up to 10 minutes (Figure 2.7). It shows clearly that complex 2.1 is sensitive enough to detect $\mathrm{H}_{2} \mathrm{O}_{2}$ at concentrations as low as $0.1 \mathrm{mM}$. There is linear response of absorbance with increasing the reaction time at each of concentration. Since a stirring system was not used in our instrument, the rate of oxidation or response time depends on diffusion. These conditions were not optimized and addition of a stirring mechanism or flow cell should improve response time.

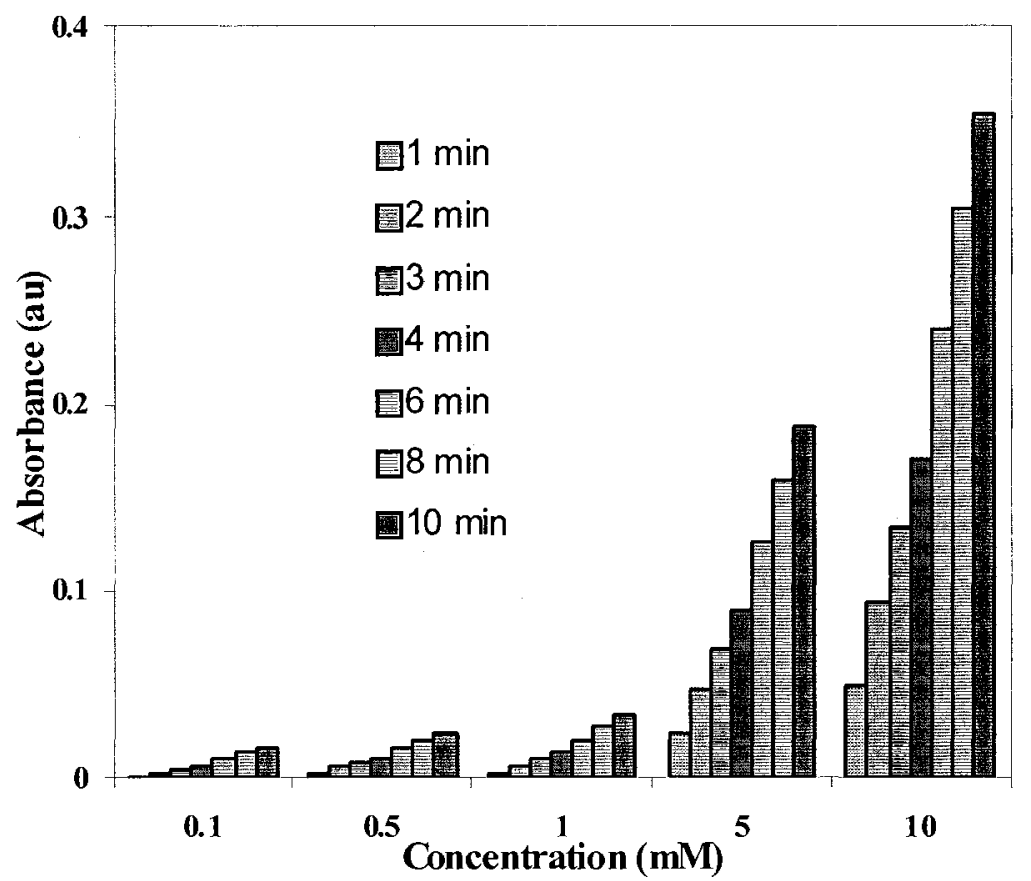

Figure 2.7. Absorbance $(1150 \mathrm{~nm})$ of complex $2.1\left(1 \times 10^{-4} \mathrm{M}\right.$ in 1:1 acetonitrile: Tris buffer) in the $\mathrm{Ru}^{\mathrm{II}} / \mathrm{Ru}^{\mathrm{II}}$ state by oxidization with different concentrations of $\mathrm{H}_{2} \mathrm{O}_{2}$ recorded at different time. 
In addition, a similar experiment was done using a crosslinked polyurethane film doped with complex 2.1. A thin film $(0.58 \mu \mathrm{m})$ coated on a slide of indium tin oxide (ITO) glass, to act as an electrode, exhibited the two broad redox couples at the potentials similar to those of complex 2.1 in solution (Figure 2.3). The film-coated ITO plate was placed in a TRIS buffer solution (pH $=7.4)(2 \mathrm{~mL})$ in a cuvette and $50 \mu \mathrm{L}$ of $\mathrm{H}_{2} \mathrm{O}_{2}$ (35 wt. \% solution in water) was introduced to oxidize complex 2.1 doped in the film to its $\mathrm{Ru}^{\mathrm{II}} / \mathrm{Ru}^{\mathrm{III}}$ state, while monitoring the increase in absorbance at $1150 \mathrm{~nm}$ simultaneously. After 8 minutes, a bias $(-500 \mathrm{mV})$ was applied to the ITO plate after placing it in a tetraethylammonium perchlorate/acetonitrile solution $(0.1 \mathrm{M})$ to reduce the complex to its $\mathrm{Ru}^{\mathrm{II}} / \mathrm{Ru}^{\mathrm{II}}$ state. The cycling experiments were repeated nine times with an excellent reproducibility (Figure 2.8). The slight variation of the absorbance change most probably arose from the unoptimized test technique. The crosslinked film tightly adhered to the ITO electrode and was stable to prolonged soaking in acetonitrile and TRIS buffer solution. There was no noticeable damage to the film on the ITO plate after many cycles of treatment of $\mathrm{H}_{2} \mathrm{O}_{2}$ and electrical reduction. 


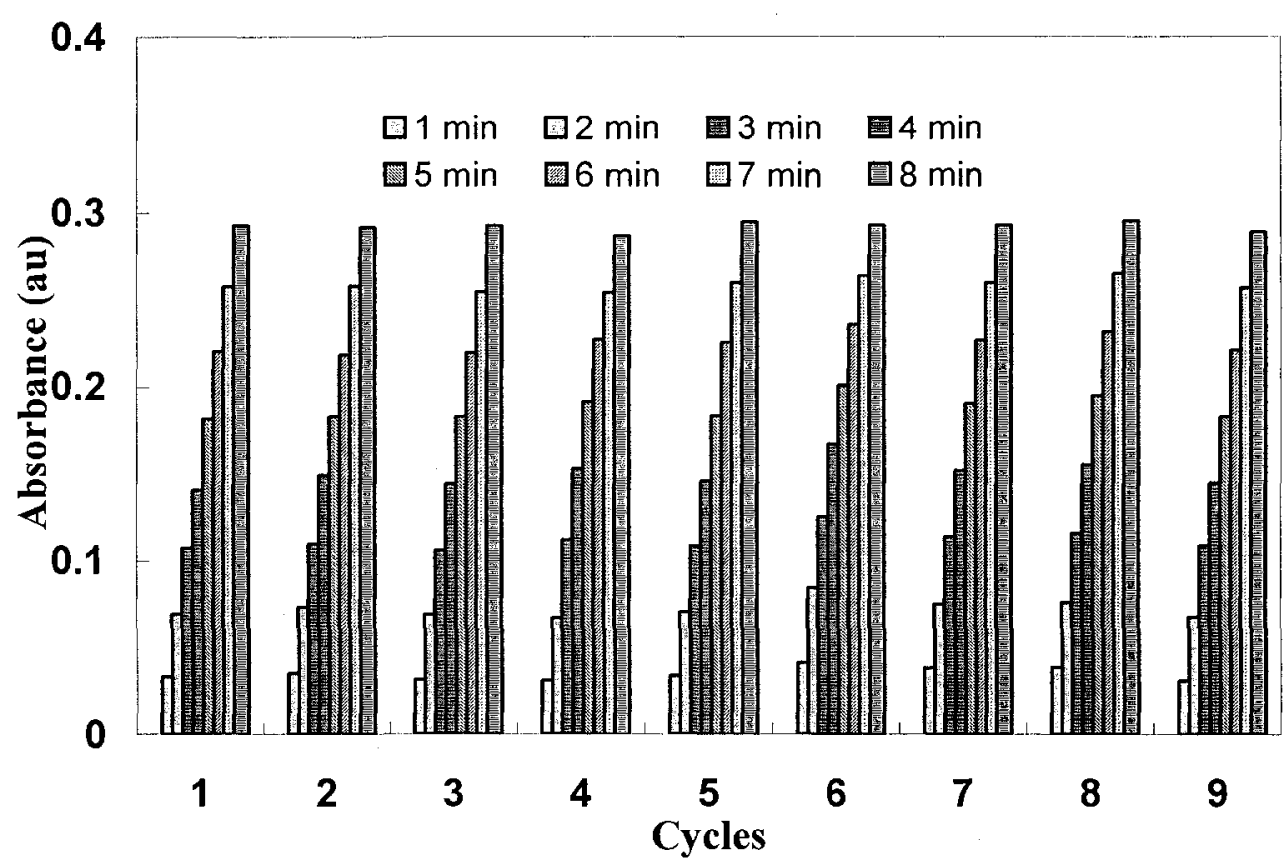

Figure 2.8. Normalized absorbance $(1150 \mathrm{~nm})$, recorded in real time, of a film containing complex 2.1 in the $\mathrm{Ru}^{\mathrm{II}} / \mathrm{Ru}^{\mathrm{II}}$ state oxidized with $\mathrm{H}_{2} \mathrm{O}_{2}(0.3 \mathrm{M})$ in TRIS buffer solution. Film was reduced electrochemically $(-0.5 \mathrm{~V})$.

\subsection{Redox-responsive PL based on DCH-Ru complexes}

It is known that DCH-Ru complexes have three reversible oxidation states, each of which gives a specific absorption spectrum. If anionic dyes are chosen as counterions for DCH-Ru complexes instead of $\mathrm{BF}_{4}^{-}, \mathrm{ClO}_{4}^{-}$or $\mathrm{PF}_{6}^{-}$, the emission of dyes might be controlled depending on the ET between dyes and DCH-Ru complexes by altering oxidation states of DCH-Ru complexes.

The mechanism of DCH-Ru complex controlled PL of dyes is shown in Figure 2.9. A dye in its excited state can transfer its energy by a nonradiative, long-range dipole-dipole coupling mechanism to an acceptor of DCH-Ru complex and thus the emission of the dye is quenched. ${ }^{4}$ However, when the oxidation state of DCH-Ru complex is altered or its MLCT band energy is increased, there will be no ET from the excited dye to DCH-Ru complex and thus the emission of dye 
can be observed. Therefore, a potential can be applied to control the redox states of DCH-Ru complexes, which in turn triggers the on and off of PL of anionic dyes. The efficiency of PL on/off depends on the ET efficiency or spectral overlap of the donor emission and the acceptor absorption.

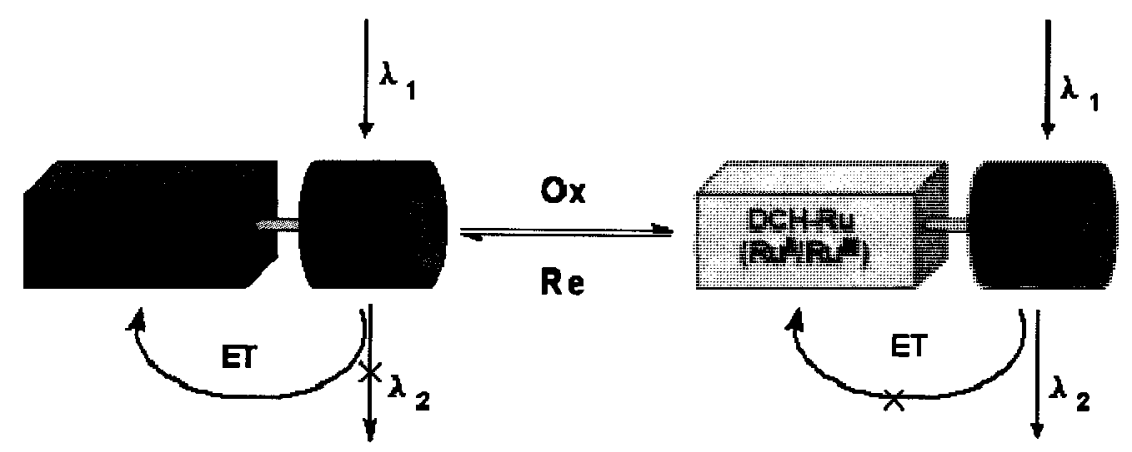

Figure 2.9. Mechanism of DCH-Ru complex controlled PL of dye.

In this study, two anionic dyes, 4,5-benzoindotricarbocyanine dye (IR125) and sulforhodamine B (SRB), were chosen as counterions for DCH-Ru complexes. The structure of complex 2.1-IR125, the emission spectrum of IR125 and absorption spectra of complex $2.1\left(\mathrm{Ru}^{\mathrm{II}} / \mathrm{Ru}^{\mathrm{II}}\right)$ and $\left(\mathrm{Ru^{ \textrm {II } }} / \mathrm{Ru}{ }^{\mathrm{III}}\right)$ are shown in Figure 2.10. The PL emission of IR125 overlaps the MMCT absorption band of complex $2.1\left(\mathrm{Ru}^{\mathrm{II}} / \mathrm{Ru}^{\mathrm{III}}\right)$, which results in an ET from IR125 to complex 2.1 $\left(\mathrm{Ru}^{\mathrm{II}} / \mathrm{Ru} \mathrm{III}^{\mathrm{II}}\right)$, and thus the emission of IR125 will be quenched by complex 2.1 $\left(\mathrm{Ru}^{\mathrm{II}} / \mathrm{Ru} \mathrm{uII}^{\mathrm{III}}\right)$. When complex 2.1 is in the $\mathrm{Ru}^{\mathrm{II}} / \mathrm{Ru}{ }^{\mathrm{II}}$ state, the $\mathrm{PL}$ of IR125 will be seen because there is no effective ET between them or no overlap between the emission of IR125 and the absorption spectrum of complex $2.1\left(\mathrm{Ru}^{\mathrm{II}} / \mathrm{Ru}{ }^{\mathrm{II}}\right)$. Therefore, the PL of IR125 is expected to be turned off upon electrochemical 
oxidation of complex 2.1 to its $\mathrm{Ru}^{\mathrm{II}} / \mathrm{Ru}^{\mathrm{III}}$ state and turned on by electrochemical reduction back to its $\mathrm{Ru}^{\mathrm{II}} / \mathrm{Ru} \mathrm{u}^{\mathrm{II}}$ state.

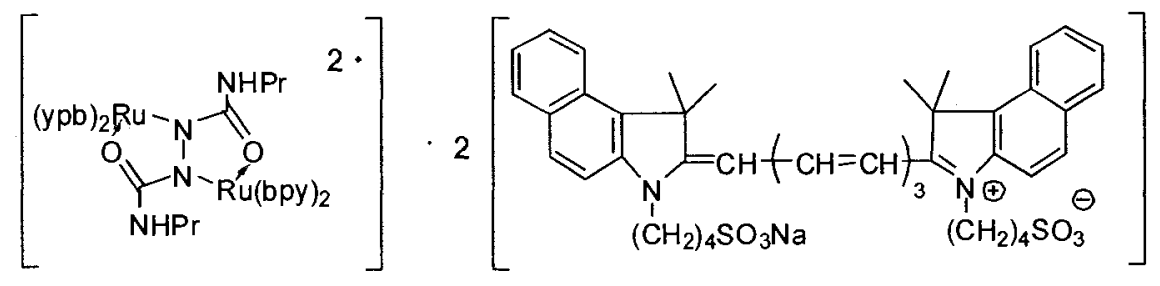

Complex 2.1-IR125

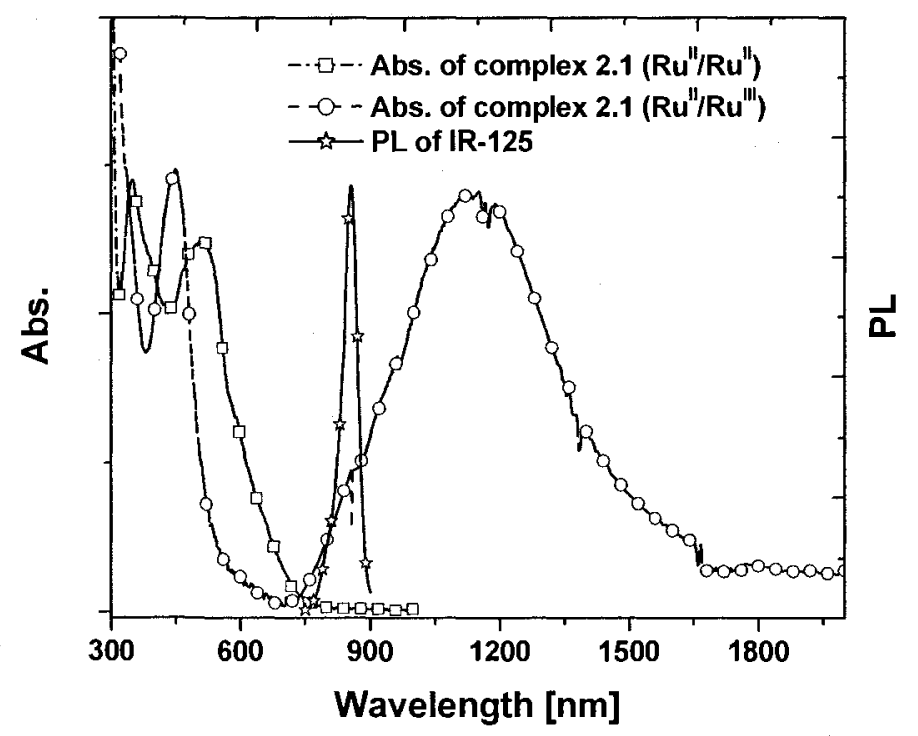

Figure 2.10. Structure of complex 2.1-IR125, PL spectrum of IR125 in methanol $\left(10^{-5} \mathrm{M}\right)$ and absorption spectra of complex $2.1\left(\mathrm{Ru}^{\mathrm{II}} / \mathrm{Ru}^{\mathrm{II}}\right)$ and $\left(\mathrm{Ru}^{\mathrm{II}} / \mathrm{Ru}^{\mathrm{III}}\right)$ in $\mathrm{CH}_{3} \mathrm{CN}\left(10^{-5} \mathrm{M}\right)$.

For complex 2.4-SRB, the PL of SRB overlaps the absorption of complex $2.4\left(\mathrm{Ru}^{\mathrm{II}} / \mathrm{Ru}^{\mathrm{II}}\right)$ and thus the PL of SRB will be quenched by complex 2.4 in the $\mathrm{Ru}^{\mathrm{II}} / \mathrm{Ru} \mathrm{II}^{\mathrm{II}}$ state (Figure 2.11). However, because of partial overlaping, the ET is not efficient and PL quenching will be incomplete. 


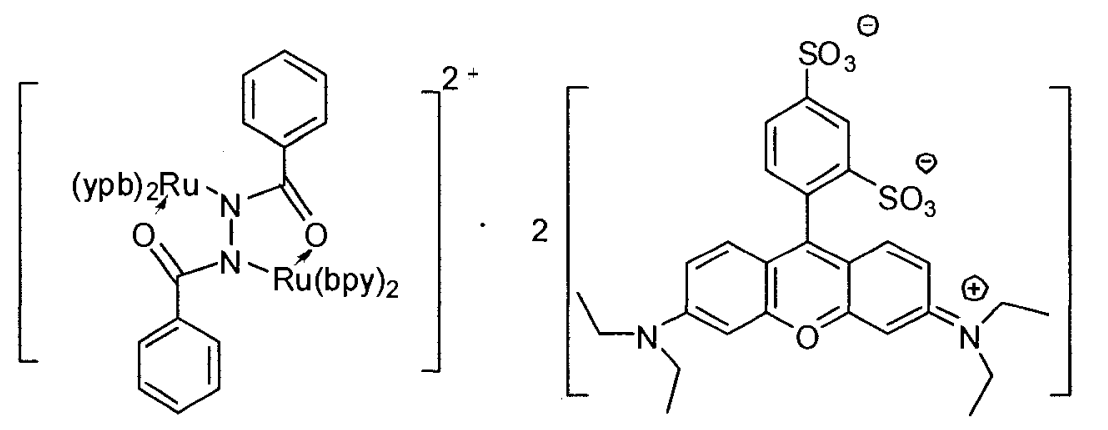

Complex 2.4-SRB

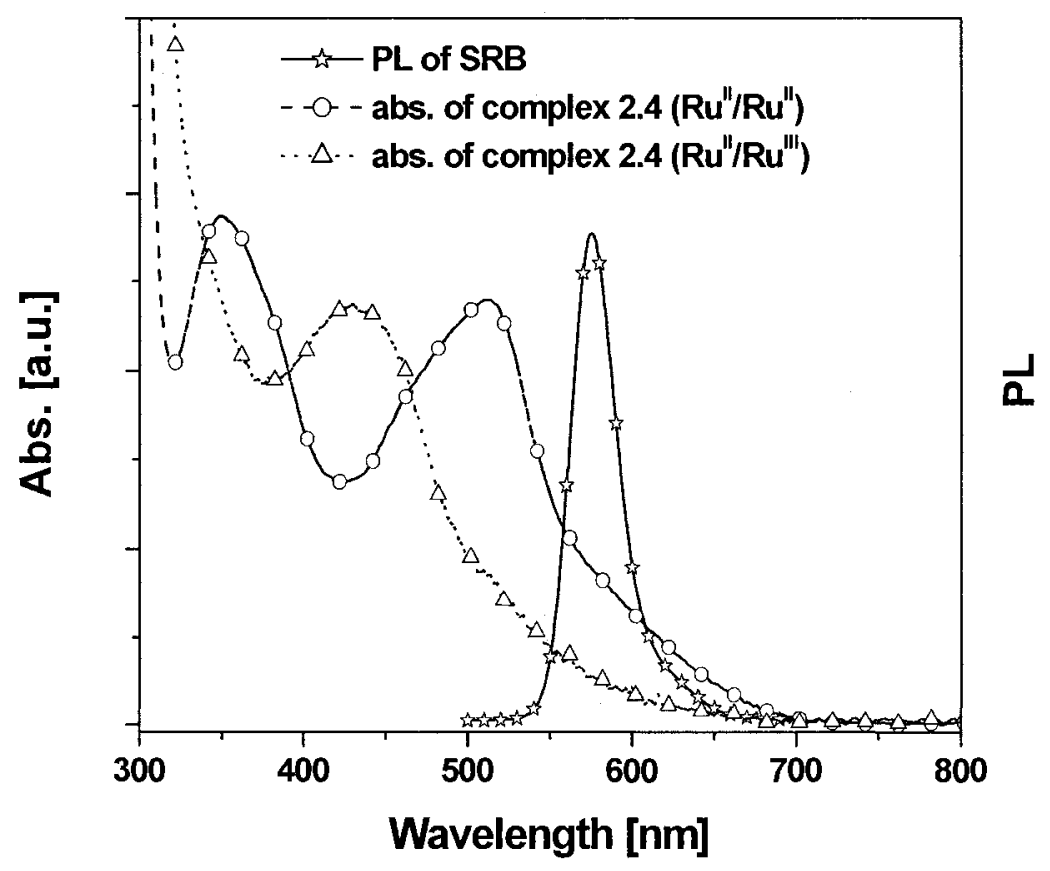

Figure 2.11. Structure of complex 2.4-SRB, PL spectrum of SRB in methanol $\left(10^{-5} \mathrm{M}\right)$ and absorption spectra of complex $2.4\left(\mathrm{Ru}^{\mathrm{II}} / \mathrm{Ru}^{\mathrm{II}}\right)$ and $\left(\mathrm{Ru} / \mathrm{RI} \mathrm{R}^{\mathrm{III}}\right)$ in $\mathrm{CH}_{3} \mathrm{CN}\left(10^{-5} \mathrm{M}\right)$.

\subsubsection{Absorption, photoluminescent and electrochemical properties of} complex 2.1-IR125

In order to confirm the ET between complex 2.1 and IR125, the PL of IR125 in methanol upon addition of complex $2.1\left(\mathrm{Ru}^{\mathrm{II}} / \mathrm{Ru}^{\mathrm{II}}\right)$ as investigated. Figure 2.12 displays the PL quenching of IR125 in methanol $\left(10^{-5} \mathrm{M}\right)$ in the presence of complex $2.1\left(\mathrm{Ru}^{\mathrm{II}} / \mathrm{Ru}^{\mathrm{II}}\right)$ with different ratios. The intensity of PL 
emission of IR125 decreased as the amount of complex $2.1\left(\mathrm{Ru}^{\mathrm{II}} / \mathrm{Ru} \mathrm{u}^{\mathrm{Il}}\right)$ increased.

The PL of IR125 was quenched about half at the ratio of $5: 1$ (IR125: 2.1). From

Figure 2.8, the ET from IR125 to complex $2.1\left(\mathrm{Ru}^{\mathrm{II}} / \mathrm{Ru}^{\mathrm{II}}\right)$ seems to be none or a minimum because there is almost no spectral overlap between them. Therfore, the observed PL quenching could come from bound and diffusive collisions or a weak ion-pair charge transfer between anionic IR125 and cationic complex 2.1 $\left(\mathrm{Ru}^{\mathrm{II}} / \mathrm{Ru}^{\mathrm{II}}\right)^{5}$

When complex 2.1 was in the $\mathrm{Ru}^{\mathrm{II}} / \mathrm{Ru}$ III state, the PL of IR125 was quenched significantly due to the efficient ET from the PL of IR125 to the MLCT band of complex 2.1 (Figure 2.13). When the ratio of IR125 and complex 2.1 was increased to 5:1, the emission of IR125 was quenched completely. Even at the ratio of $1: 1,76 \%$ of the PL was quenched.

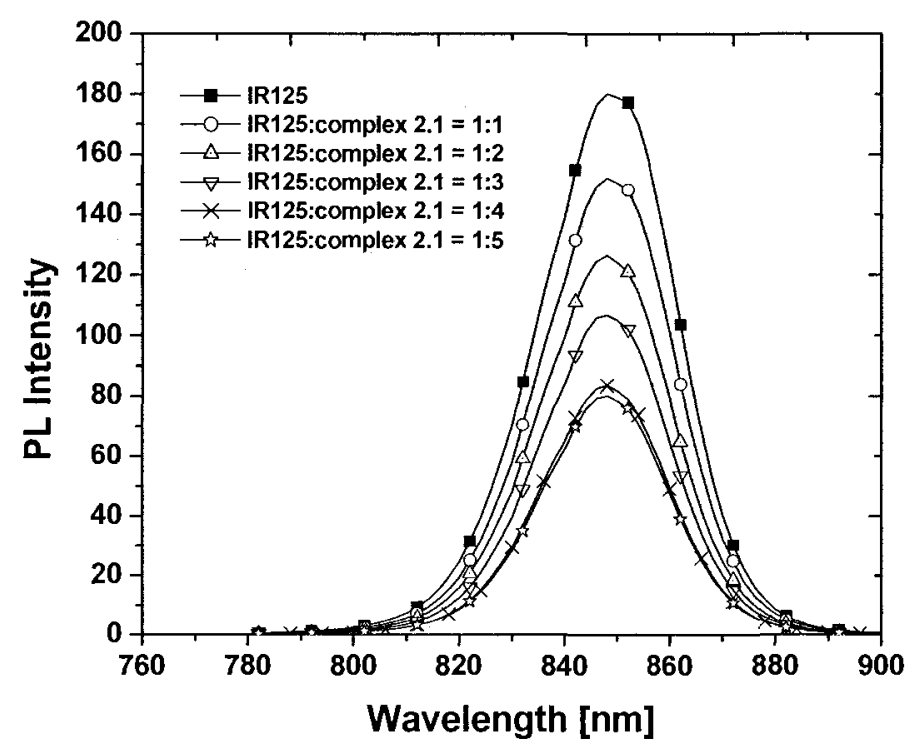

Figure 2.12. PL quenching of IR 125 by complex $2.1\left(\mathrm{Ru}^{\mathrm{II}} / \mathrm{Ru}^{\mathrm{II}}\right)$ in methanol. 


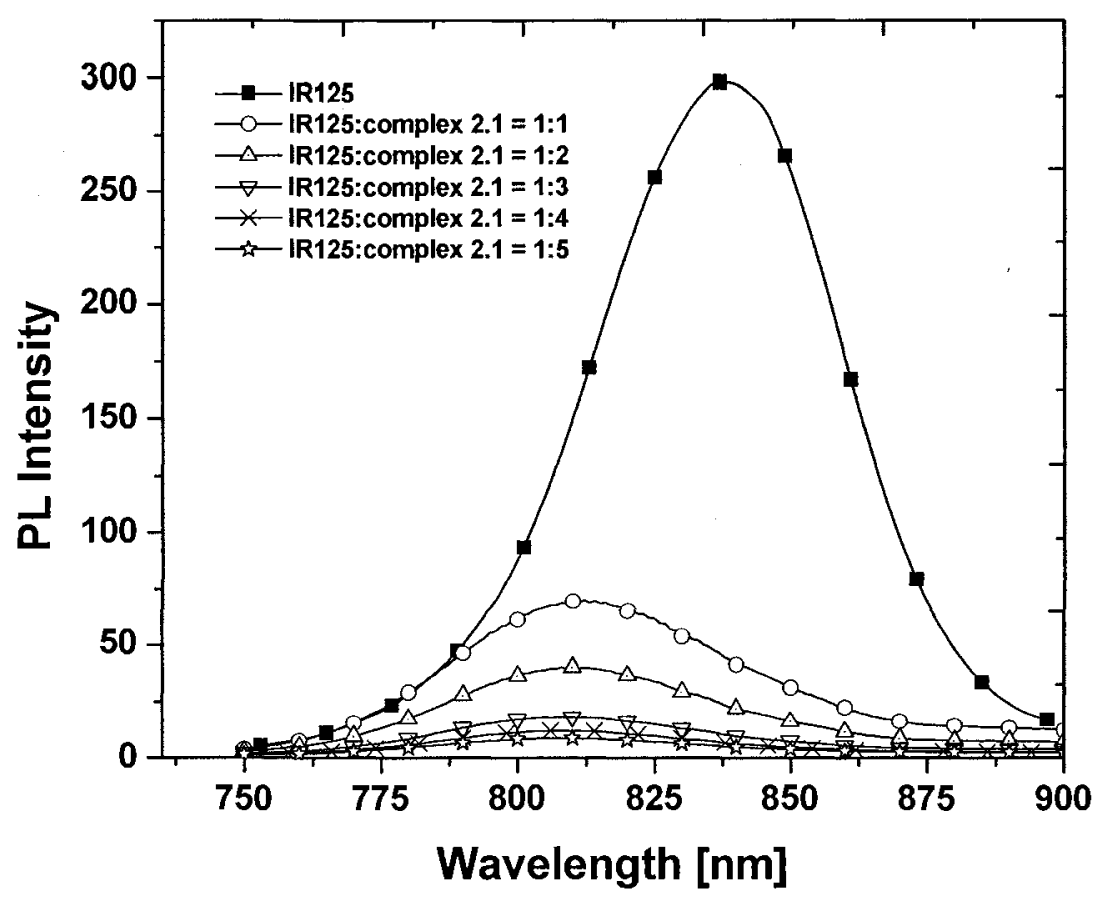

Figure 2.13. PL quenching of IR125 by complex $2.1\left(\mathrm{Ru}^{\mathrm{II}} / \mathrm{Ru}^{\mathrm{III}}\right)$ in methanol.

As shown in Figure 2.14, complex 2.1 in the mixed-valence state quenches the emission of IR125 much more significantly. The PL of IR125 was quenched by $9 \%$ by complex $2.1\left(R u^{\mathrm{II}} / \mathrm{Ru}^{\mathrm{II}}\right)$ and up to $76 \%$ by complex $2.1\left(\mathrm{Ru} / \mathrm{Ru}{ }^{\mathrm{III}}\right)$ at the same ratio of 1:1 (complex 2.1: IR125). The same trend was observed at other ratios. 


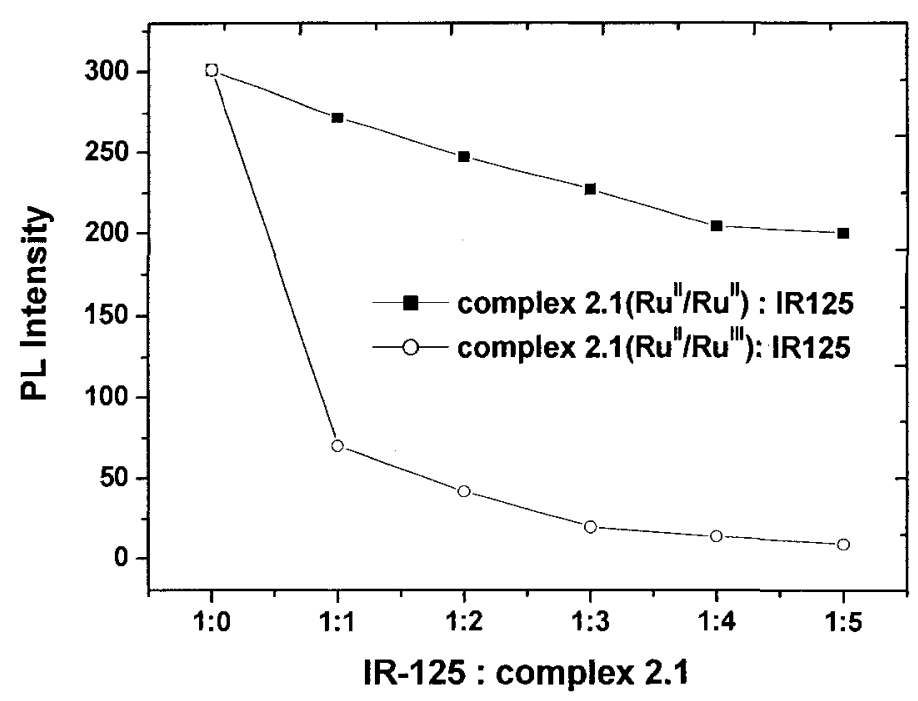

Figure 2.14. PL quenching of IR125 with the different content of complex 2.1 in the $\mathrm{Ru}^{\mathrm{II}} / \mathrm{Ru}^{\mathrm{II}}$ and $\mathrm{Ru} \mathrm{u}^{\mathrm{II}} / \mathrm{Ru}{ }^{\mathrm{III}}$ states.

CV graphs of complex 2.1, IR125 and complex 2.1-IR125 at the positive potential range are shown in Figure 2.15. The potentials are calibrated against the ferrocene/ferrocenium couple. Complex 2.1 exhibited two successive reversible metal oxidations at the positive potential range. For IR125, one oxidation peak at $440 \mathrm{mV}$ was observed. As expected, for complex 2.1-IR125, three oxidation waves were observed, two of which could be assigned to complex 2.1 and the other attributed to IR125. Moreover, relative to complex 2.1, the second oxidation waves of complex 2.1 -IR125 cathodically shifted about $100 \mathrm{mV}$. 


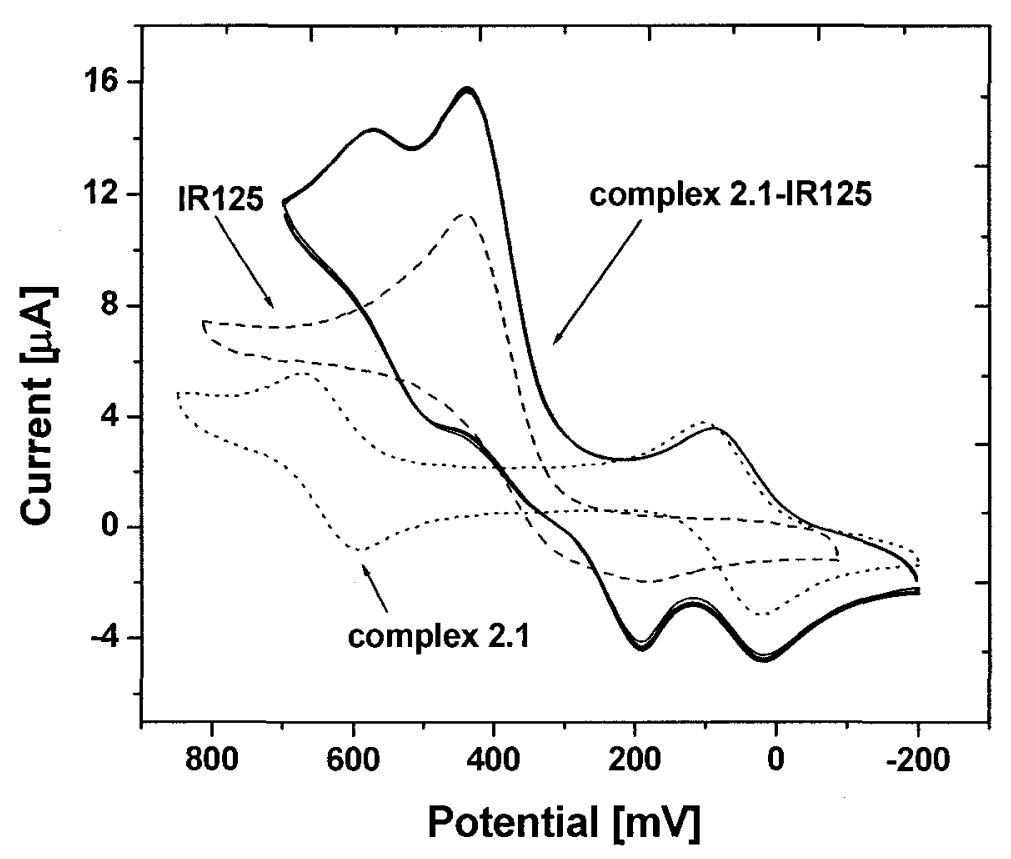

Figure 2.15. $\mathrm{CV}$ graphs of complex 2.1 in $0.1 \mathrm{M} \mathrm{NEt}_{4} \mathrm{ClO}_{4} / \mathrm{CH}_{3} \mathrm{CN}$, IR125 in $0.1 \mathrm{M} \mathrm{NEt}_{4} \mathrm{ClO}_{4} /$ methanol and complex 2.1-IR125 in $0.1 \mathrm{M} \mathrm{NEt}_{4} \mathrm{ClO}_{4} / \mathrm{DMF}$ at a scan rate of $100 \mathrm{mVs}^{-1}$.

The spectroelectrochemical property of complex 2.1-IR125 was studied in $0.1 \mathrm{M} \mathrm{NEt}_{4} \mathrm{ClO}_{4} / \mathrm{DMF}$ with an optically transparent thin-layer electrochemical (OTTLE) cell. To avoid oxidizing IR125, the applied potential was kept below the oxidation potential of IR125 (400 mV) (Figure 2.15). Complex 2.1 is oxidized to the mixed-valence state, when the applied potential is greater than $100 \mathrm{mV}$. Figure 2.16 displays the absorptional changes of complex 2.1-IR125 by applying a potential from $100 \mathrm{mV}$ to $400 \mathrm{mV}$. Unfortunately, IR125 is not stable under the bias conditions. The absorption at $790 \mathrm{~nm}$ associated with IR125 decreased dramatically even by applying $100 \mathrm{mV}$ for 3 minutes. No peak at $1150 \mathrm{~nm}$ corresponding to MMCT of complex $\mathbf{2 . 1}$ in the $\mathrm{Ru} / \mathrm{Ru}{ }^{\mathrm{III}}$ state appeared at $400 \mathrm{mV}$ after 3 minutes. 


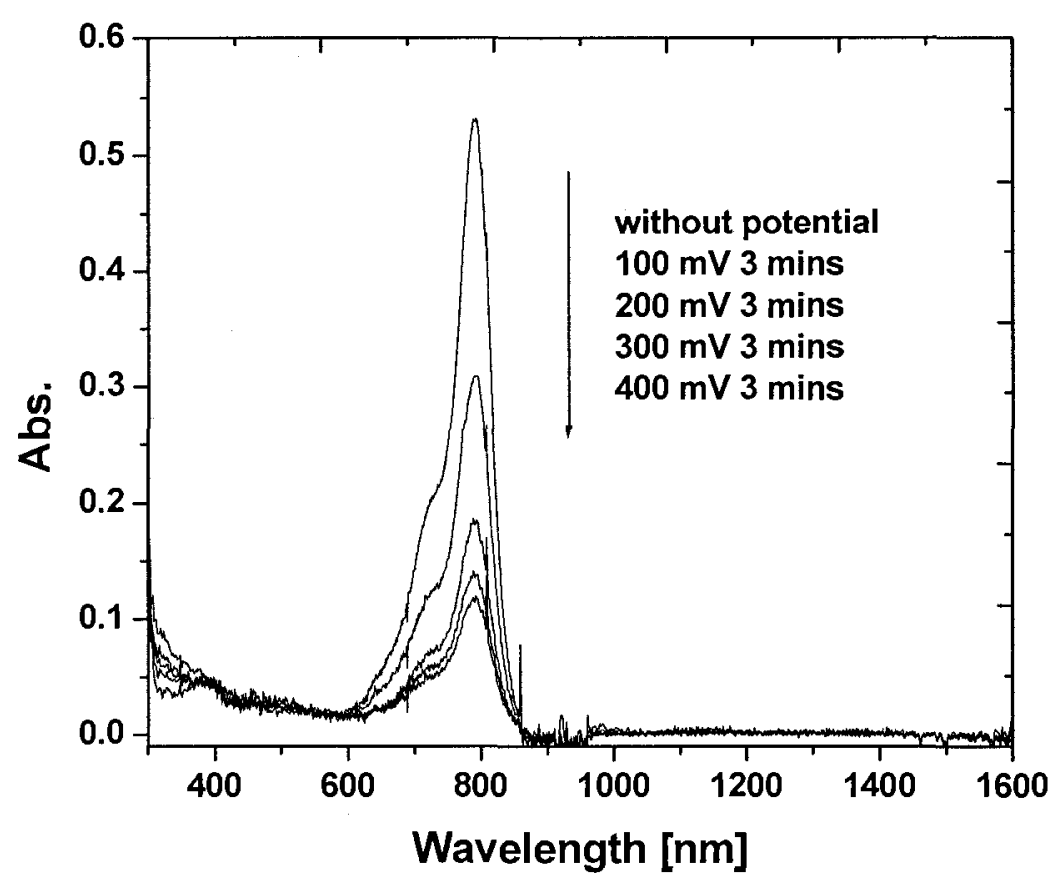

Figure 2.16. Absorption changes of complex 2.1-IR125 in $0.1 \mathrm{M} \mathrm{NEt}_{4} \mathrm{ClO}_{4} /$ DMF by applying different potential with an OTTLE cell.

\subsubsection{Absorption, photoluminescent and electrochemical properties of} complex 2.4-SRB

The PL quenching of SRB in methanol by adding complex $2.4\left(R u^{\mathrm{Il}} / \mathrm{Ru}{ }^{\mathrm{Il}}\right)$ was first investigated to confirm ET from SRB to complex $2.4\left(\mathrm{Ru}^{\mathrm{II}} / \mathrm{Ru}^{\mathrm{II}}\right)$. As shown in Figure 2.17, the PL intensity of SRB decreased dramatically upon adding complex $2.4\left(\mathrm{Ru}^{\mathrm{II}} / \mathrm{Ru}^{\mathrm{II}}\right)$. The emission of SRB was completely quenched at the ratio of $1: 5(\mathrm{SRB}: \mathbf{2 . 1})$. Even at the ratio of $1: 1$, the emission of $\mathrm{SRB}$ was quenched by $70 \%$.

In contrast to complex 2.4 in the $\mathrm{Ru}^{\mathrm{II}} / \mathrm{Ru} \mathrm{u}^{\mathrm{II}}$ state, the PL quenching of SRB in methanol by complex $2.4\left(\mathrm{Ru}^{\mathrm{II}} / \mathrm{Ru} \mathrm{u}^{\mathrm{III}}\right)$ is less significant because of inefficient ET between complex $2.4\left(\mathrm{Ru}^{\mathrm{II}} / \mathrm{Ru}^{\mathrm{III}}\right)$ and SRB. Figure 2.18 shows that the 
intensity of emission of SRB at $575 \mathrm{~nm}$ decreases to some extent upon addition of complex $2.4\left(\mathrm{Ru}^{\mathrm{II}} / \mathrm{Ru}^{\mathrm{III}}\right)$. As shown in Figure 2.19 , the PL of SRB was quenched by $68 \%$ by complex $2.4\left(\mathrm{Ru}^{\mathrm{II}} / \mathrm{Ru}^{\mathrm{II}}\right)$ and $20 \%$ by complex $2.4\left(\mathrm{Ru} / \mathrm{Ru}{ }^{\mathrm{III}}\right)$ at the ratio of $1: 1$.

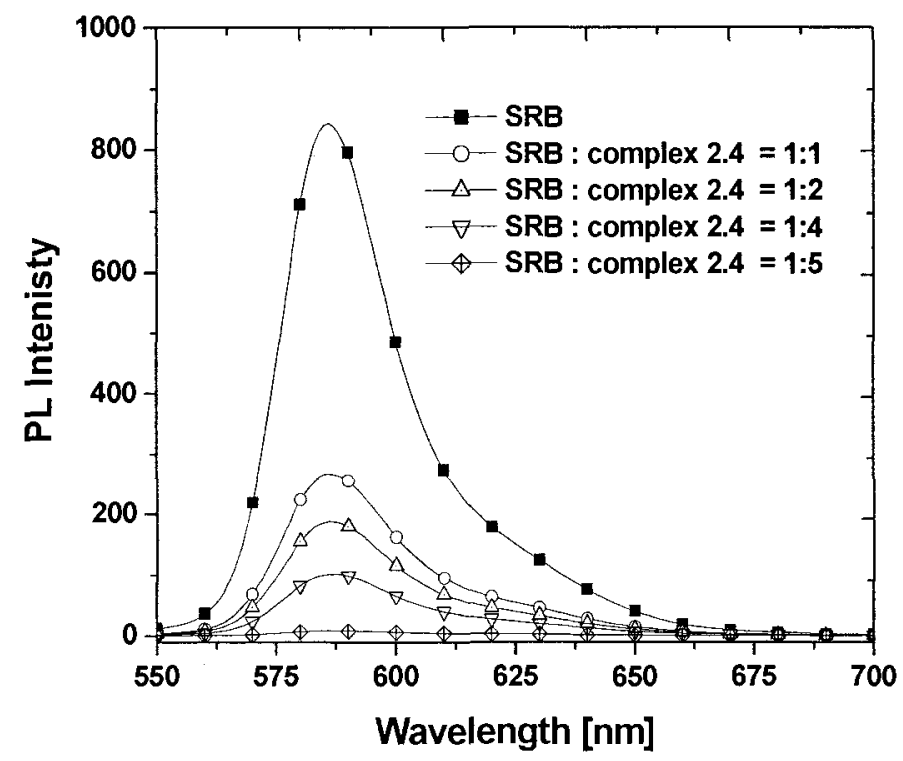

Figure 2.17. PL quenching of SRB by complex $2.4\left(\mathrm{Ru}^{\mathrm{II}} / \mathrm{Ru} \mathrm{u}^{\mathrm{II}}\right)$ in methanol.

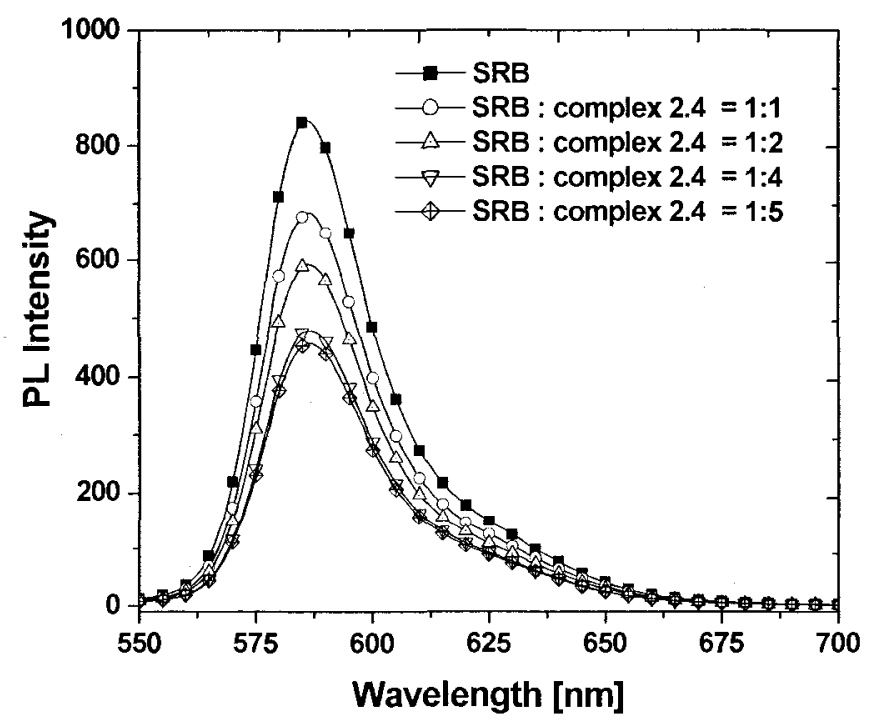

Figure 2.18. PL quenching of SRB by complex $2.4\left(\mathrm{Ru}^{\mathrm{II}} / \mathrm{Ru}{ }^{\mathrm{III}}\right)$ in methanol. 


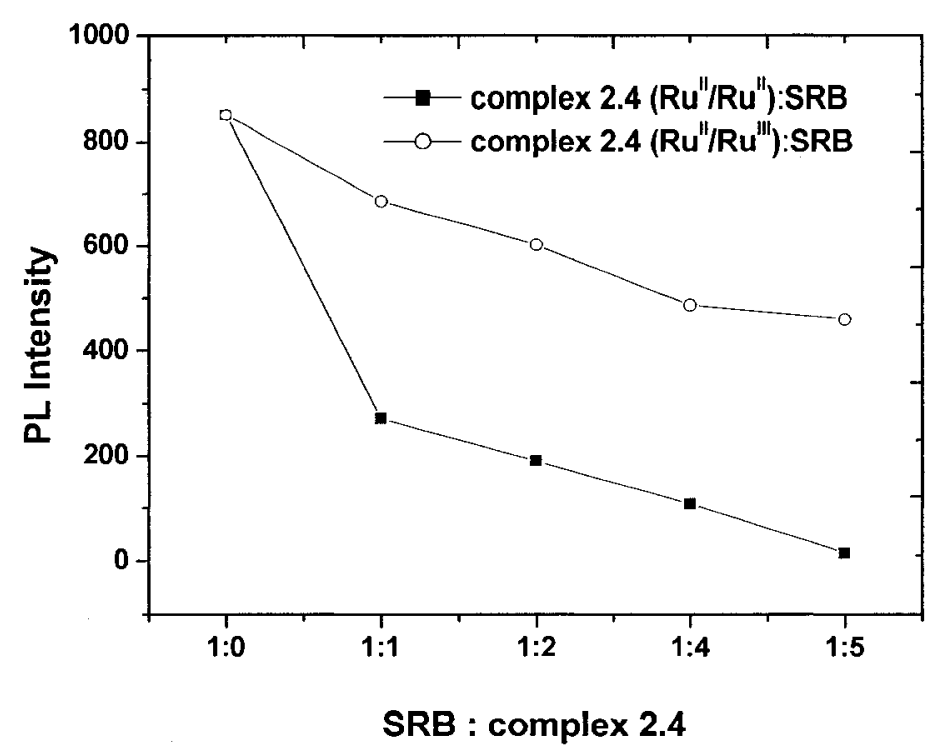

Figure 2.19. PL quenching of SRB with the different content of complex 2.4 in the $\mathrm{Ru}^{\mathrm{II}} / \mathrm{Ru}^{\mathrm{II}}$ and $\mathrm{Ru}^{\mathrm{II}} / \mathrm{Ru}{ }^{\mathrm{III}}$ states.

Figure 2.20 shows the CV graphs of complex 2.4-SRB and complex 2.4 in $0.1 \mathrm{M} \mathrm{NEt} \mathrm{ClO}_{4} / \mathrm{DMF}$. Complex 2.4-SRB and complex 2.4 exhibited two successive oxidations at a positive potential range, being associated with the successive $\mathrm{Ru}^{\mathrm{II}} / \mathrm{Ru}^{\mathrm{III}}$ couple. No peaks assigned to SRB were observed at a positive potential range. Within the negative potential range, complex 2 .4-SRB displays two reversible reduction waves with the first one being assigned to the $\mathrm{SRB}$ reduction. The second one could be assigned to reduction of the bpy ligand, which is consistent with that of complex 2.4 . 


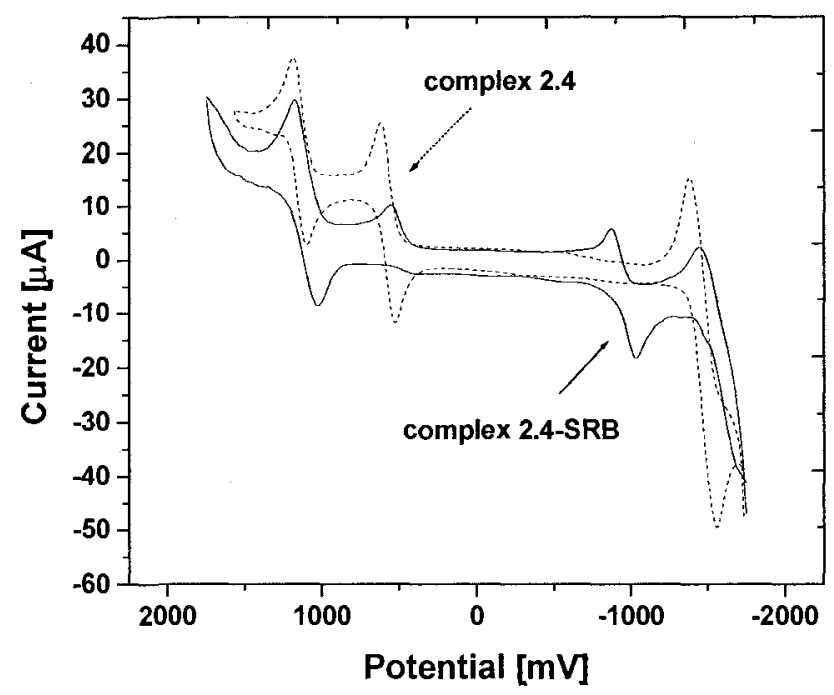

Figure 2.20. $\mathrm{CV}$ of complex 2.4 and complex 2.4-SRB in $0.1 \mathrm{M}$ $\mathrm{NEt}_{4} \mathrm{ClO}_{4} / \mathrm{DMF}$ at a scan rate of $100 \mathrm{mVs}^{-1}$.

To test the electrochemical stability of complex 2.4-SRB, a crosslinked polyurethane film doped with complex 2.4-SRB was fabricated on ITO glass. Platinum wire and silver wire were used as auxiliary electrode and reference electrode, respectively. The film-coated ITO plate was placed in $0.1 \mathrm{M} \mathrm{NEt}_{4} \mathrm{ClO}_{4} /$ $\mathrm{CH}_{3} \mathrm{CN}$. There is no obvious change after 20 switching cycles (Figure 2.21).

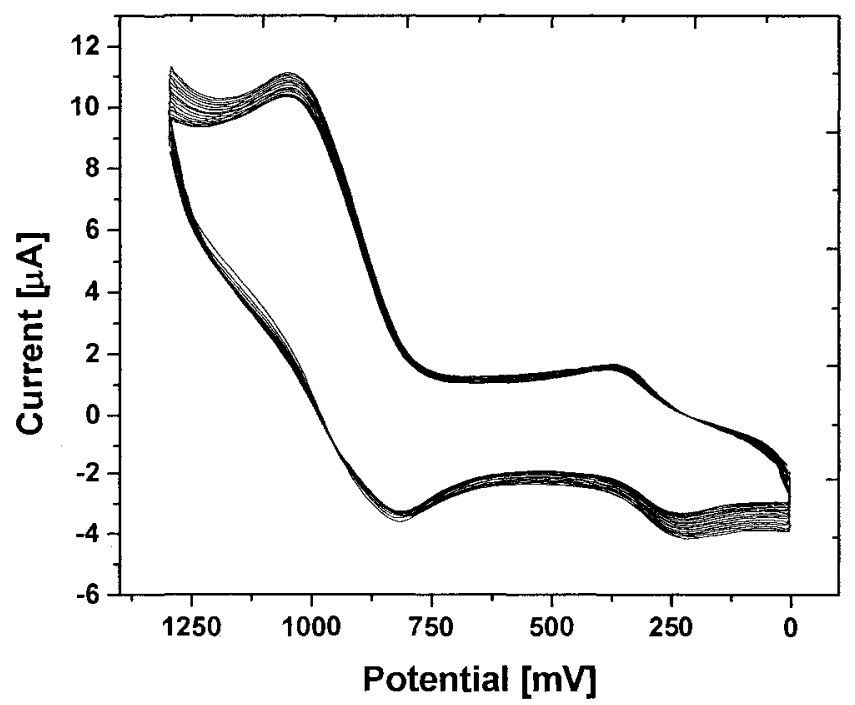

Figure 2.21. $\mathrm{CV}$ of complex 2.4-SRB film in $0.1 \mathrm{M} \mathrm{NEt}_{4} \mathrm{ClO}_{4} / \mathrm{CH}_{3} \mathrm{CN}$ at a scan rate of $100 \mathrm{mV} / \mathrm{s}(20$ cycles $)$. 
Figure 2.22 shows the absorption spectra of complex 2.4-SRB in the $\mathrm{Ru}^{\mathrm{II}} / \mathrm{Ru}$ II and $\mathrm{Ru} / \mathrm{Ru}{ }^{\mathrm{III}}$ states. The peak at $550 \mathrm{~nm}$ is assigned to the SRB and absorption maximum at $1600 \mathrm{~nm}$ is attributed to the MMCT of ruthenium complex. Similar absorption spectra were obtained with a crosslinked polyurethane film doped with complex $2.4-\mathrm{SRB}(15 \mathrm{wt} \%)$ in the $\mathrm{Ru} / \mathrm{Ru} \mathrm{u}^{\mathrm{II}}$ state and the mixed-valence state after electrochemical oxidation (Figure 2.23).

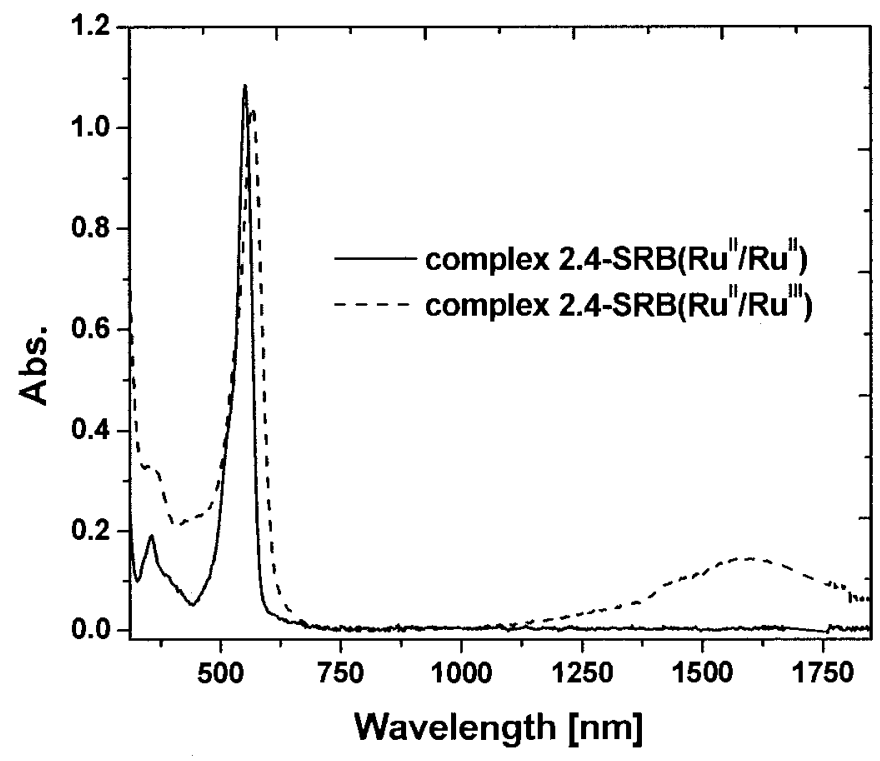

Figure 2.22. Absorption spectra of complex 2.4-SRB in $0.1 \mathrm{M}$ $\mathrm{NEt}_{4} \mathrm{ClO}_{4} / \mathrm{CH}_{3} \mathrm{CN}$ using an OTTLE cell.

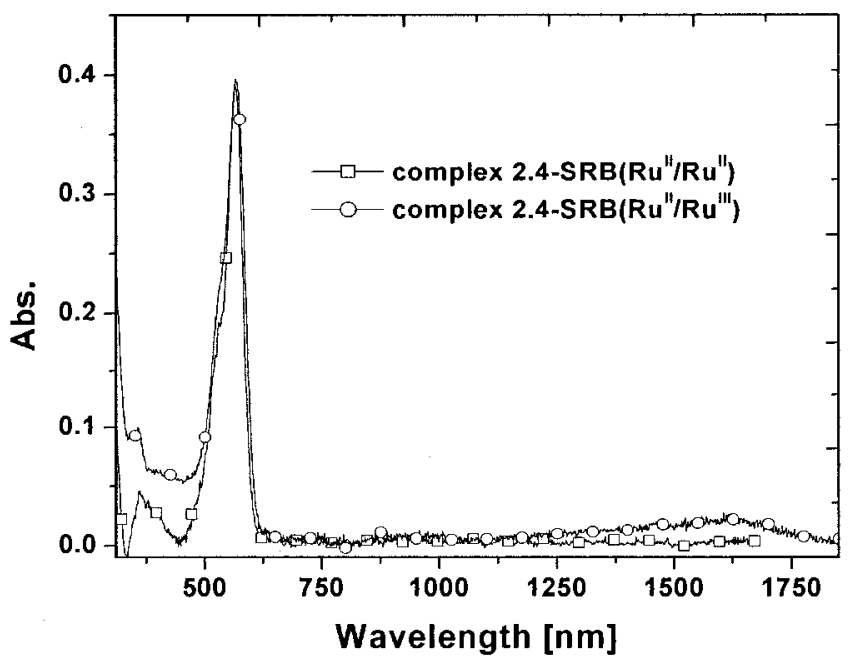

Figure 2.23. Absorption spectra of a film containing complex 2.4-SRB (15 $\mathrm{wt} \%)$. 
Since complex 2.4-SRB exhibited a good electrochemical stability, a total of five films of crosslinked polyurethane doped with a different amount of complex 2.4-SRB were prepared for further evaluation of PL switching properties. Figure 2.24 shows the PL intensity of these films after the doped complex being oxidized to the $\mathrm{Ru}^{\mathrm{Il}} / \mathrm{Ru}{ }^{\mathrm{III}}$ state by applying a potential of $500 \mathrm{mV}$. For $6 \mathrm{wt} \%$ complex 2.4-SRB doped film, no emission was observed in the $\mathrm{Ru}^{\mathrm{II}} / \mathrm{Ru}^{\mathrm{II}}$ state, but a very strong emission with a maximum at $590 \mathrm{~nm}$ appeared after the complex was oxidized to the $\mathrm{Ru}^{\mathrm{Il}} / \mathrm{Ru}^{\mathrm{III}}$ state by electrochemical means. The oxidization of complex 2.4-SRB to the mixed-valence state was monitored by UV-vis-NIR spectroscopy. Similar results were obtained with other films doped with different amounts of complex 2.4-SRB. The emission could be quenched once complex 2.4-SRB was reduced to the $\mathrm{Ru}^{\mathrm{II}} / \mathrm{Ru}^{\mathrm{II}}$ state. Thus, the PL switching could be induced by the electrochemical oxidation or reduction of complex 2.4 .

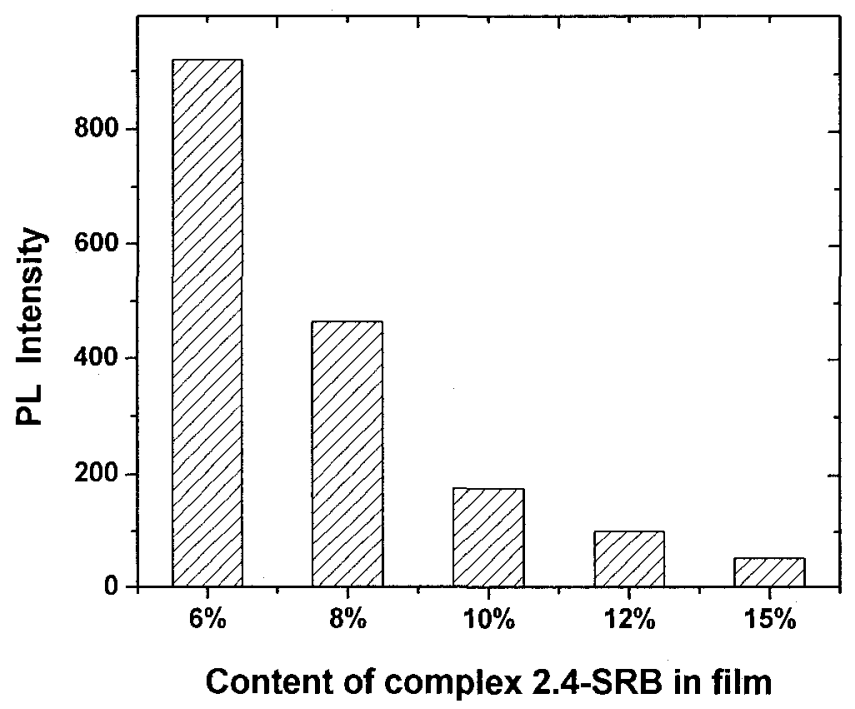

Figure 2.24. PL intensity $(590 \mathrm{~nm})$ of films containing different amounts of complex 2.4-SRB in the $\mathrm{Ru}^{\mathrm{Il}} / \mathrm{Ru}^{\mathrm{III}}$ state after being oxidized electrochemically. 


\subsection{Conclusion}

The four DCH-Ru complexes presented herein show strong NIR absorption in the mixed-valence state and reversible redox properties. The spectroscopic and electrochemical properties of these complexes are affected by the electron-withdrawing or electron-donating ability of substituents and correlate well to the Hammett substituent parameters.

The ruthenium complexes with relatively low oxidation potentials can be used to detect $\mathrm{H}_{2} \mathrm{O}_{2}$ or other peroxides by monitoring the NIR absorption after being oxidized to the mixed-valence states. Furthermore, DCH-Ru complexes can be used to electrochemically control the emission of redox-inactive fluorescent dyes, as a result from the controlled ET between complexes and dyes.

\section{$2.7 \quad$ Experiments}

\section{Materials}

n-Propylisocyanate, ethyl carbazate, ethyl chloroformate, benzoic hydrazide, benzoyl chloride, 2,2'-dipyridyl, trimethylolpropane, xylylene diisocyanate, and sodium carbonate were purchased from Aldrich Chemicals Inc., Canada. Hydrazine hydrate ( $85 \%$ wt./v) was purchased from ACP Inc, Montreal, Canada. $\mathrm{RuCl}_{3} \cdot 3 \mathrm{H}_{2} \mathrm{O}$ was purchased from Pressure Chemicals Co. $\mathrm{Ru}(\mathrm{bpy})_{2} \mathrm{Cl}_{2} \cdot 2 \mathrm{H}_{2} \mathrm{O}$ was prepared according to a published procedure. ${ }^{6}$ All solvents were ACS reagent grade or higher and used as received. 


\section{Measurements}

Absorption spectra and PL spectra were recorded in methanol or $\mathrm{CH}_{3} \mathrm{CN}$ $\left(10^{-5} \mathrm{M}\right)$ or ruthenium complex doped polyurethane film on ITO glass using a Perkin Elmer Lambda 900 UV-vis-NIR spectrophotometer and a PTI spectrophotometer, respectively.

Melting points were measured on a Fisher-Jones melting point apparatus and are uncorrected. Mass spectrometry (EI and ESI) was carried out by the University of Ottawa Regional Mass Spectrometry Center and peaks are reported as $\mathrm{m} / \mathrm{z}$ (\% intensity relative to the base peak).

The ${ }^{1} \mathrm{H}$ and ${ }^{13} \mathrm{C}$ NMR spectra were carried on a Bruker Avance-300 and chemical shifts were reported in ppm using tetramethylsilane (TMS) as an internal standard.

Spectroelectrochemical measurements in solution were conducted using an OTTLE cell as shown in Figure 2.25. The Au working electrode was replaced by ITO glass to create a transparent light path. In addition, a platinum wire and silver wire were fixed in two etched ITO parts as auxiliary electrode and reference electrode, respectively. Cyclic voltammograms and controlled-potential electrolyses using an OTTLE cell were carried out with a BAS $100 \mathrm{~W}$ electrochemical station. 


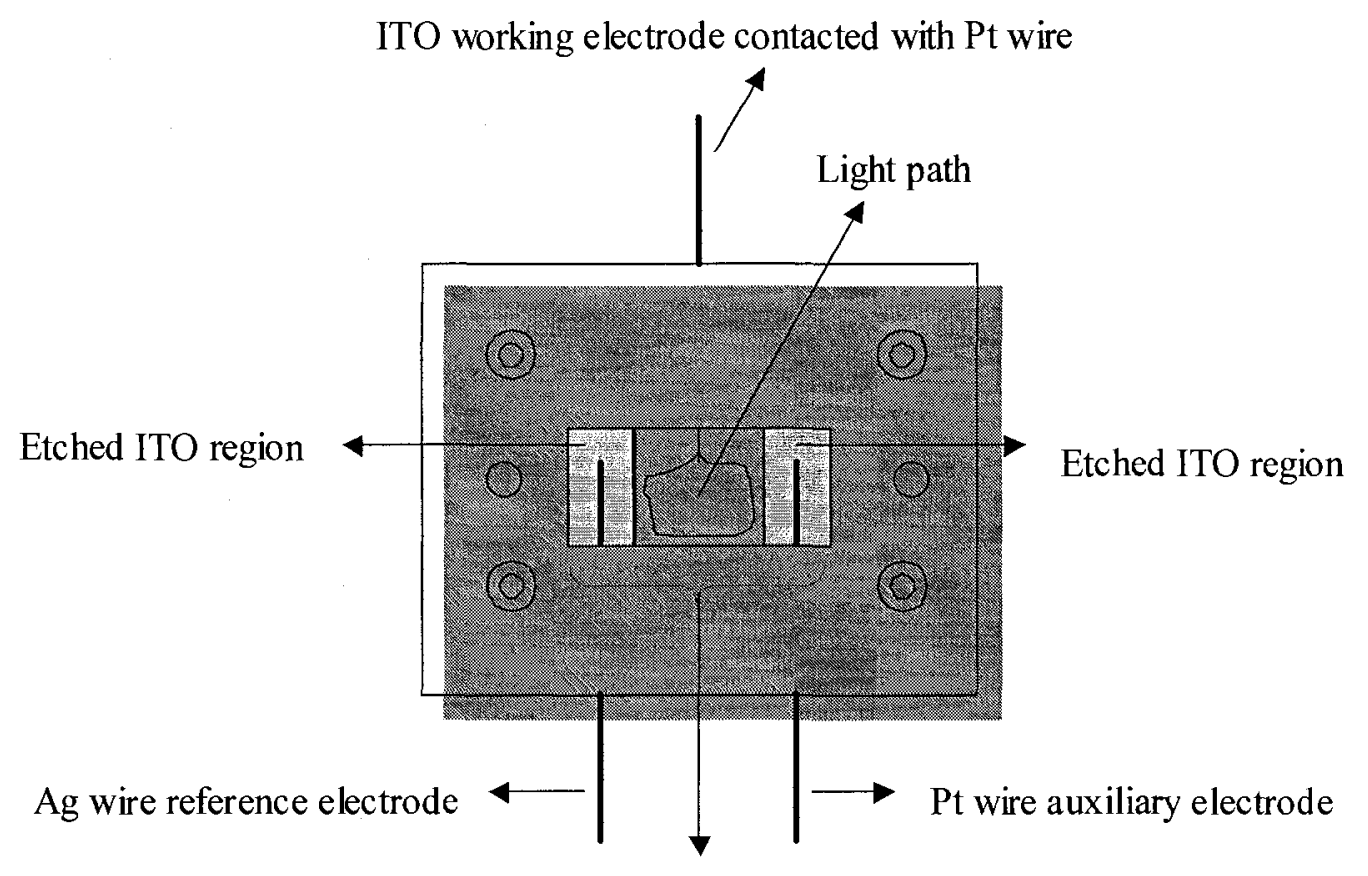

Ruthenium complex in $0.1 \mathrm{M} \mathrm{NEt}_{4} \mathrm{ClO}_{4} / \mathrm{DMF}$

Figure 2.25. Schematic diagram of OTTLE cell (front view).

Spectroelectrochemical and switching experiments in films were performed within a $1 \mathrm{~cm}$ quartz cuvette, with ruthenium complex doped polyurethane film coated on ITO glass as a working electrode, a platinum wire as the auxiliary electrode and silver wire as the reference electrode. $0.1 \mathrm{M} \mathrm{NEt} \mathrm{ClO}_{4} / \mathrm{CH}_{3} \mathrm{CN}$ was used as a supporting electrolyte solution, which was bubbled with argon for 10 minutes prior to the experiment (Figure 2.26). The film containing ruthenium complexes was electrochemically oxidized or reduced. The potential was controlled using a BAS $100 \mathrm{~W}$ electrochemical station and the redox process was monitored by UV-Vis-NIR spectroscopy. 


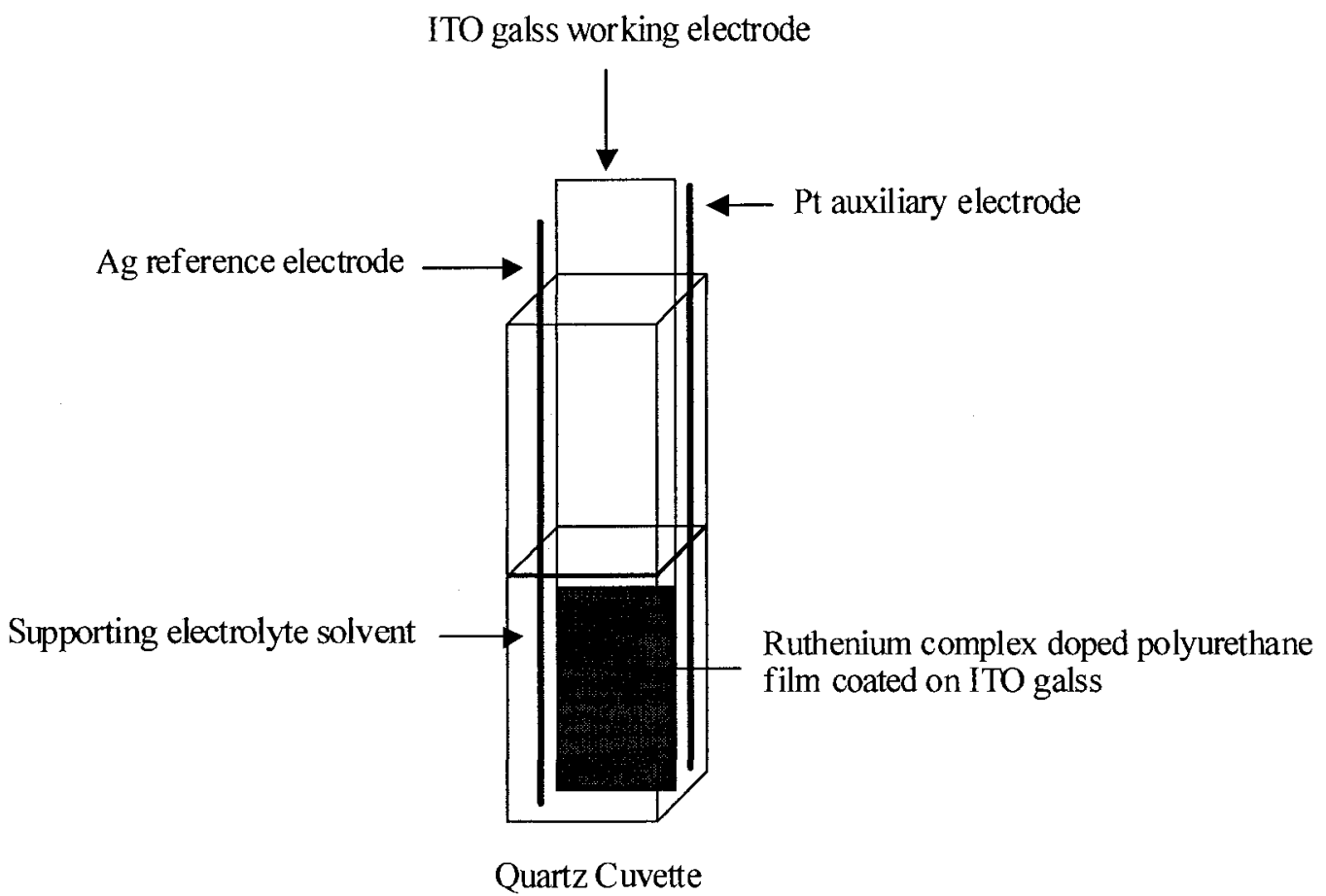

Figure 2.26. Set-up of spectroelectrochemcial and switching experiments.

\section{Fabrication of a crosslinked polyurethane film}

Complex 2.1 (7.4 wt.\%), trimethylolpropane, carbamate with xylylene diisocyanate, trimethylolpropane and tetraethylammonium hexa-flurophosphate (9.2 wt. \%) were mixed in $1 \mathrm{~mL}$ of acetonitrile and sonicated for 1 hour and then spin coated on an ITO plate $(0.8 \times 2.5 \mathrm{~cm})$. After cure at $50^{\circ} \mathrm{C}$ under vacuum for $1 \mathrm{~h}$, a film with a thickness of $0.58 \mu \mathrm{m}$ was formed.

\section{Synthesis of ligands}

\section{1,2-Di(N-propylcarbamyl)hydrazide (L1)}

n-Propyl isocyanate $(3.60 \mathrm{~g}, 42.3 \mathrm{mmol})$, hydrazine hydrate $(1.00 \mathrm{~g}, 19.9$ $\mathrm{mmol}$ ) in $50 \mathrm{~mL}$ of THF were placed in a $100 \mathrm{~mL}$, round-bottomed flask and stirred for $4 \mathrm{~h}$ at room temperature. The white solids were filtered, washed with 
THF and dried over night under vacuum. The yield was $3.5 \mathrm{~g}(88 \%) .{ }^{1} \mathrm{H}$ NMR $\left(300 \mathrm{MHz}, \mathrm{d}_{6}-\mathrm{DMSO}\right): \delta 0.83(\mathrm{t}, 6 \mathrm{H}), 1.39(\mathrm{~m}, 4 \mathrm{H}), 2.95(\mathrm{q}, 4 \mathrm{H}), 6.27(\mathrm{~s}, 2 \mathrm{H})$, $7.48(\mathrm{~s}, 2 \mathrm{H}) ;{ }^{13} \mathrm{C}$ NMR $\left(75 \mathrm{MHz}, \mathrm{d}_{6}\right.$-DMSO): $\delta$ 11.7, 23.5, 41.3, 158.6; EI-MS $m / z$ (\% relative intensity): $202\left(1.0, \mathrm{M}^{+}\right), 144(7.0), 117(28.7), 169(48), 56(55.5) ; \mathrm{mp}$ $262-264^{\circ} \mathrm{C}$.

\section{1-Ethoxycarbonyl-4-propyl semicarbazide (L2)}

A mixture of ethyl carbazate $(0.85 \mathrm{~g}, 10 \mathrm{mmol})$ and $\mathrm{n}$-propyl isocyanate $(1.0 \mathrm{~g}, 10 \mathrm{mmol})$ in a mortar was ground with a pestle for 30 minutes according to a previously reported method. ${ }^{12 a}$ The mixture was washed with dry toluene or n-hexane and the solids were filtered off and dried to give 1-ethoxycarbonyl-4-propyl semicarbazide. The yield was $1.5 \mathrm{~g}(80 \%) .{ }^{1} \mathrm{H}$ NMR $\left(300 \mathrm{MHz}, \mathrm{d}_{6}-\mathrm{DMSO}\right): \delta 0.81(\mathrm{t}, 3 \mathrm{H}), 1.17(\mathrm{t}, 3 \mathrm{H}), 1.37(\mathrm{~m}, 2 \mathrm{H}), 2.95(\mathrm{q}, 2 \mathrm{H})$, $4.01(\mathrm{q}, 2 \mathrm{H}), 6.32(\mathrm{~s}, 1 \mathrm{H}), 7.63(\mathrm{~s}, 1 \mathrm{H}), 8.73(\mathrm{~s}, 1 \mathrm{H}) ;{ }^{13} \mathrm{C}$ NMR $(75 \mathrm{MHz}$, $\mathrm{d}_{6}$-DMSO): $\delta 11.7,15.0,23.5,41.4,60.8,157.4,158.7$; EI-MS $m / z$ (\% relative intensity): $189\left(0.5, \mathrm{M}^{+}\right), 144(8.0) ; \mathrm{mp} 103-104{ }^{\circ} \mathrm{C}$.

\section{Ethyl hydrazodicarboxylate (L3)}

Ethyl chloroformate $(10.5 \mathrm{~g}, 100 \mathrm{mmol})$ was added dropwise with stirring to a solution of hydrazine hydrate $(1.8 \mathrm{~g}, 47 \mathrm{mmol})$ in $30 \mathrm{~mL}$ of ethanol. The reaction flask was cooled in an ice bath to maintain the temperature at $15{ }^{\circ} \mathrm{C} \sim 20$ ${ }^{\circ} \mathrm{C}$. After exactly one-half of the ethyl chloroformate was introduced, a solution of 
sodium carbonate $(5.3 \mathrm{~g}, 50 \mathrm{mmol})$ in $40 \mathrm{~mL}$ of water was added dropwise simultaneously with the remaining ethyl chloroformate. After addition of the reagents was complete, the reaction mixture was stirred for 30 minutes. The white precipitate was filtered, washed with $30 \mathrm{~mL}$ of water then $15 \mathrm{~mL}$ of $95 \% \mathrm{EtOH}$ followed by ethyl ether and dried overnight under vacuum. The yield was $3.6 \mathrm{~g}$ (52\%). ${ }^{1} \mathrm{H}$ NMR (300 MHz, d $\mathrm{d}_{6}$-DMSO): $\delta 1.17(\mathrm{t}, 6 \mathrm{H}), 4.03(\mathrm{q}, 4 \mathrm{H}), 8.99(\mathrm{~s}, 2 \mathrm{H})$;

${ }^{13} \mathrm{C}$ NMR (75 MHz, $\mathrm{d}_{6}$-DMSO): $\delta$ 15.0, 60.9,157.0; EI-MS $m / z$ (\% relative intensity): $176\left(9.1, \mathrm{M}^{+}\right), 104(44.4) ; \mathrm{mp} 131-133^{\circ} \mathrm{C}$.

\section{1,2-Dibenzoylhydrazide (L4)}

A solution of benzoic hydrazide $(2.10 \mathrm{~g}, 16.6 \mathrm{mmol})$ and sodium carbonate $(1.60 \mathrm{~g}, 16.6 \mathrm{mmol})$ in $30 \mathrm{~mL}$ of THF and $20 \mathrm{~mL}$ of water was added to a solution of benzoyl chloride $(2.6 \mathrm{~g}, 18 \mathrm{mmol})$ in $30 \mathrm{~mL}$ of $\mathrm{THF}$ at $0^{\circ} \mathrm{C}$. The mixture was stirred for 3 hours. The white precipitate was collected by filtration, washed three times with $25-\mathrm{mL}$ portions of THF and dried overnight under vacuum. The yield was $3.0 \mathrm{~g}(75 \%) .{ }^{1} \mathrm{H}$ NMR $\left(300 \mathrm{MHz}, \mathrm{d}_{6}\right.$-DMSO): $\delta 7.51(\mathrm{t}, 4 \mathrm{H}), 7.58(\mathrm{~m}, 2 \mathrm{H})$, $7.92(\mathrm{~d}, 4 \mathrm{H}), 10.54(\mathrm{~s}, 2 \mathrm{H}) ;{ }^{13} \mathrm{C}$ NMR $\left(75 \mathrm{MHz}, \mathrm{d}_{6}\right.$-DMSO): $\delta$ 127.8, 128.9, 131.9, 133.7, 165.7; EI-MS $m / z$ (\% relative intensity): $240\left(5.1, \mathrm{M}^{+}\right), 222(6.1), 165$ (6.9); $\operatorname{mp} 238-239^{\circ} \mathrm{C}$. 


\section{General procedure for synthesis of complexes 2.1-2.4}

The procedure for synthesis of complex 2.4 is given below. A solution of 1,2-dibenzoylhydrazide $(0.40 \mathrm{~g}, 1.7 \mathrm{mmol}), \mathrm{Ru}(\mathrm{bpy})_{2} \mathrm{Cl}_{2} \cdot 2 \mathrm{H}_{2} \mathrm{O}(1.8 \mathrm{~g}, 3.5 \mathrm{mmol}$, ) and $\mathrm{NaOH}(0.30 \mathrm{~g}, 7.5 \mathrm{mmol})$ in $60 \mathrm{~mL}$ of $\mathrm{H}_{2} \mathrm{O} / \mathrm{EtOH}(5: 1 \mathrm{v}: \mathrm{v})$ was refluxed for approximately $24 \mathrm{~h}$ under argon atmosphere. After it was cooled to room temperature, the crude product was precipitated by addition of excess $\mathrm{NH}_{4} \mathrm{PF}_{6}$. The resulting solids were collected by filtration, re-dissolved in acetone, precipitated in ethyl ether, filtered and air dried. Purification of crude complex was done on a $4 \times 10 \mathrm{~cm}$ neutral alumina column using a mixture of toluene and acetonitrile $(1: 1 \mathrm{v} / \mathrm{v})$ as the mobile phase. The final product was collected as a purple solid and dried under vacuum overnight ( $88 \%$ yield). ESI-MS $m / z$ (\% relative intensity): $1352(<0.1 \%, \mathrm{M}+\mathrm{H}), 1207\left(16, \mathrm{M}_{-} \mathrm{PF} 6\right), 531\left(100, \mathrm{M}-2 \mathrm{PF}_{6}\right)$.

\section{Complex 2.1}

The product was collected as a purple solid with a yield of $65 \%$. ESI-MS $m / z$ (\% relative intensity): $1317(<0.1 \%, \mathrm{M}+\mathrm{H}), 1173\left(6, \mathrm{M}-\mathrm{PF}_{6}\right), 514(100$, $\left.\mathrm{M}-2 \mathrm{PF}_{6}\right)$.

\section{Complex 2.2}

The product was collected as a purple solid with a yield of $76 \%$. ESI-MS $m / z\left(\%\right.$ relative intensity): $1304(<0.1 \%, \mathrm{M}+\mathrm{H}), 1159\left(2, \mathrm{M}-\mathrm{PF}_{6}\right), 507(100, \mathrm{M}$ $\left.-2 \mathrm{PF}_{6}\right)$ 


\section{Complex 2.3}

The product was collected as a purple solid with a yield of $80 \%$. ESI-MS $m / z\left(\%\right.$ relative intensity): $1288(<0.1 \%, \mathrm{M}+\mathrm{H}), 1143\left(29, \mathrm{M}-\mathrm{PF}_{6}\right), 499(100$, $\left.\mathrm{M}-2 \mathrm{PF}_{6}\right)$.

\section{Complex 2.1-IR125}

Excess tetrabutylammonium chloride was added to a solution of $100 \mathrm{mg}$ of complex 2.1 in $5 \mathrm{~mL}$ of $\mathrm{CH}_{3} \mathrm{CN}$. Then, complex 2.1 with the counterion of $\mathrm{Cl}^{-}$ was precipitated, dried and dissvoled in $5 \mathrm{~mL}$ of water. Excess IR125 was added to this soltuion. The product was collected by filtration, washed three times with $5-\mathrm{mL}$ portions of water and dried under vacuum with a yield of $86 \%$.

\section{Complex 2.4-SRB}

Excess tetrabutylammonium chloride was added to a solution of $100 \mathrm{mg}$ of complex 2.4 in $5 \mathrm{~mL}$ of $\mathrm{CH}_{3} \mathrm{CN}$. Then, complex 2.4 with the counterion of $\mathrm{Cl}^{-}$ was precipitated, dried and dissvoled in $5 \mathrm{~mL}$ of water. Excess SRB was added to this soltuion. The product was collected by filtration, washed three times with 5-mL portions of water and dried under vacuum with a yield of $92 \%$. 


\section{References}

1. (a) S. Mallakpour, A. R. Hajipour, H. A. Taghizadeh, Molecules 2003, 8, 359. (b) J. C. Kauer, Organic Syntheses, John Wiley \& Sons: New York, 1976.

2. (a) Y. Qi, P. Desjardins, Z. Y. Wang, J. Opt. A: Pure Appl. Opt. 2002, 4, S273. (b) Y. Qi, Z. Y. Wang, Macromolecules 2003, 36, 3146.

3. C. Hansch, A. Leo, R. W. Taft, Chem. Rev. 1991, 91, 165.

4. (a) H. Zhang, D. M. Rudkevich, Chem. Commun. 2007, 1238. (b) J. R. Lakowicz, Principles of Fluorescence Spectroscopy, Plenum Publishing Corporation, 1983.

5. J. Wang, D. Wang, E. K. Miller, D. Moses, A. J. Heeger, Synth. Met. 2001, $119,591$.

6. B. P. Sullivan, D. J. Salmon, T. J. Meyer, Inorg. Chem. 1978, 17, 3334. 


\section{Chapter 3 Design, Synthesis and Near-Infrared Photoluminescent and Electroluminescent Properties of Ruthenium Complexes}

\subsection{Introduction}

Light-emitting electrochemical cells (LECs) based on ruthenium complexes have been well studied in recent years. ${ }^{1}$ Intrinsically, ruthenium complexes satisfy the requirements of LECs as emitting materials, as they are chemically, electrochemically, photochemically, and thermally stable, and are ionically conductive. In a film, the counter ions are mobile at room temperature.

As illustrated in Figure 3.1, LECs based on ruthenium complexes can have a simple configuration: a thin film of the ruthenium complex $(c a .100 \mathrm{~nm})$ sandwiched between the anode (ITO) and the cathode ( $\mathrm{Au}, \mathrm{Al}$, or $\mathrm{Ag}$, etc.). Scheme 3.1 shows the emission mechanism of LECs based on $\left[R u\left(L_{2}\right)\left(L^{\prime}\right)\right]^{2+}$, where the $\left[R u\left(L_{2}\right)\left(L^{\prime}\right)\right]^{+}$and $\left[R u\left(L_{2}\right)\left(L^{\prime}\right)\right]^{3+}$ species can be produced near the anode and cathode as described in equations (1) and (2). Then they transport towards the counter electrodes via hole and electron transportation. Finally, they recombine inside the bulk to generate the excited species $\left[R u\left(L_{2}\right)\left(L^{\prime}\right)\right]^{2+*}$ (equation 3), which gives out the light (equation 4). ${ }^{\text {Id }}$

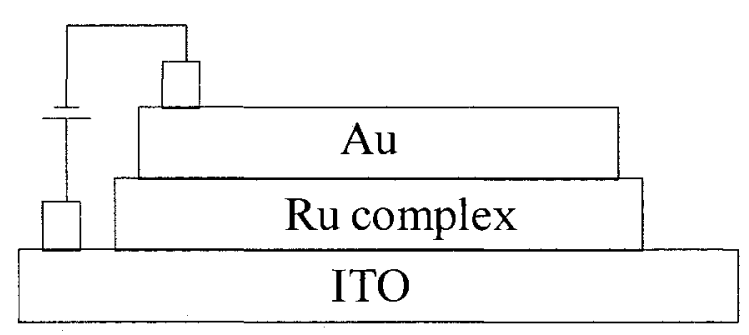

Figure 3.1. Device structure of LEC. 


$$
\begin{aligned}
& {\left[\operatorname{Ru}\left(L_{2}\right)_{2}\left(L^{\prime}\right)\right]^{2+}+e^{-} \rightarrow\left[R u\left(L_{2}\left(L^{\prime}\right)\right]^{+} \quad(1)\right.} \\
& {\left[\operatorname{Ru}\left(L_{2}\right)_{2}\left(L^{\prime}\right)\right]^{2+} \longrightarrow\left[\operatorname{Ru}\left(L_{2}\left(L^{\prime}\right)\right]^{3+}+e^{-} \quad(2)\right.} \\
& {\left[\operatorname{Ru}\left(L_{2}\right)_{2}\left(L^{\prime}\right)\right]^{+}+\left[\operatorname{Ru}\left(L_{2}\right)_{2}\left(L^{\prime}\right)\right]^{3+} \longrightarrow\left[\operatorname{Ru}\left(L_{2}\right)_{2}\left(L^{\prime}\right)\right]^{2+}+\left[R u(L)_{2}\left(L^{\prime}\right)\right]^{2+*}} \\
& {\left[\operatorname{Ru}\left(L_{2}\right)_{2}\left(L^{\prime}\right)\right]^{2+*} \longrightarrow\left[\operatorname{lRu}\left(L_{2}\right)_{2}\left(L^{\prime}\right)\right]^{2+}+h v \quad(4)}
\end{aligned}
$$

Scheme 3.1. Emission mechanism of LEC based on ruthenium complex.

According to the mechanism, the devices based on ruthenium complexes have several advantages over other OLED devices, such as simple single-layer configuration, wide selection of metal electrodes and low turn-on voltage. However, the majority of LECs based on transition metal complexes reported so far exhibit mainly orange-red emission having a maximum between 600 and 650 $\mathrm{nm}$. The availability of multiple EL colors thus remains the major challenging issue for the LECs based on metal complexes. To realize NIR electroluminescence from a LEC device based on ruthenium complexes, the materials must meet two basic requirements. (1) Energy band-gap of the materials should be less than 1.77 $\mathrm{eV}$ to achieve an emission above $700 \mathrm{~nm}$. The band-gaps of ruthenium complexes are related to their LUMO and HOMO levels and can in principle be tuned by changing the ligand structures; (2) Oxidation and reduction potential values of the complexes should ideally be equal in reference to the zero volt, to ensure a complete redox cycle under an applied bias without current breakdown in device.

With these considerations, in this chapter, we discuss the synthesis of a series of ruthenium complexes having different ligands and their optical, 
electrochemical and EL properties. The PL and EL of these complexes are expected to vary according to the LUMO and HOMO levels of the ligands, eventually leading to NIR emission.

\subsection{Design and synthesis}

A series of ruthenium complexes with different types of ligands are designed and selected with the different LUMO and HOMO levels of these materials. Figure 3.2 shows the structures of complexes 3.1-3.13. Among them, mono-nuclear ruthenium complexes 3.1-3.3, 3.6 and dinuclear ruthenium complex 3.11 are known ${ }^{5 \mathrm{a}, 6 \mathrm{a}, 6 \mathrm{~d}, 7}$ and the others are newly synthesized in this study.

Electron-rich ligands, acetylacetone (acac) and 2-(2-pyridyl)benzimidazole (PBIm-H), are chosen as bidentate ligands to lower the oxidization potential of ruthenium metal and thus increase the HOMO level of the complexes. 2,3-Bis(2-pyridyl)benzoquinoxaline ( $\mathrm{dpb}$ ) with low-energy $\pi^{*}$ orbital is utilized as a bridging ligand to lower the LUMO energy of the complexes. Moreover, the dinuclear configuration is able to increase the HOMO levels of the complexes by lowering the oxidization potential (complexes 3.9-3.12).

Using both electron-rich and electron-deficient ligands should give rise to a gradual change in the LUMO-HOMO energy gap, thus allowing for stepwise tuning of the band-gap of complexes. In addition, relative to complex $\mathbf{3 . 9}$, a branched complex $\mathbf{3 . 1 3}$ is designed in order to improve the device performance by improving the film quality. 


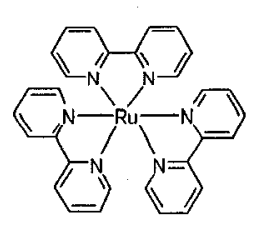

3.1

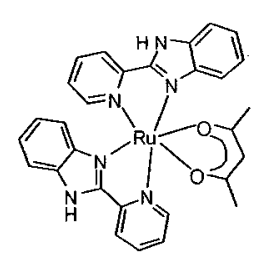

3.5

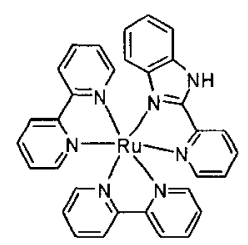

3.2

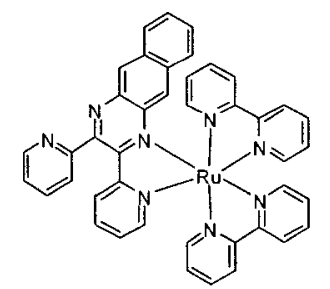

3.6

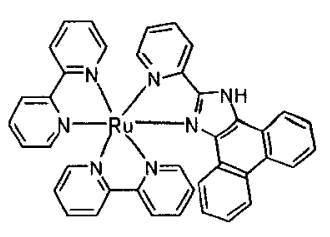

3.3
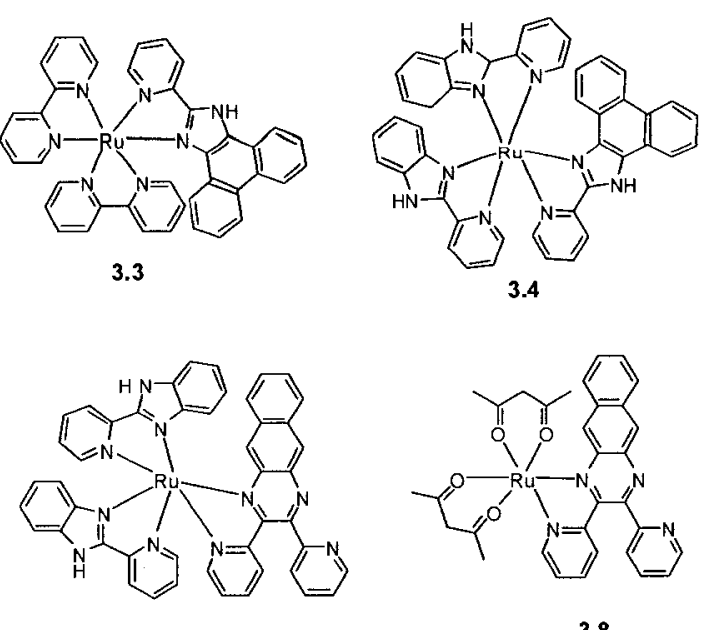

3.7

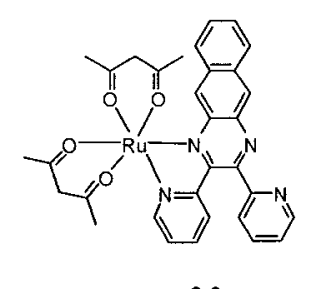

3.8

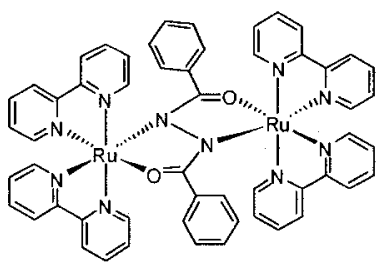

3.9

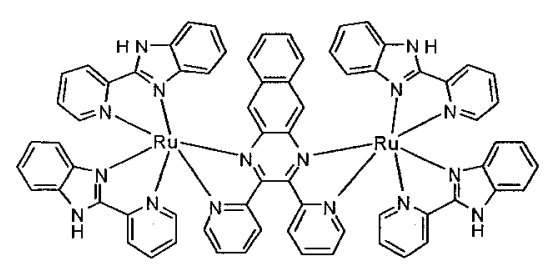

3.10

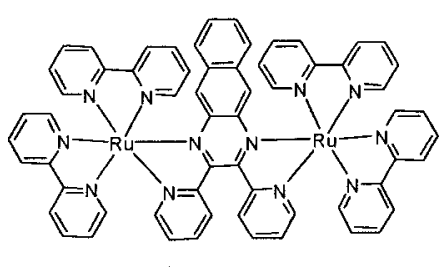

3.11

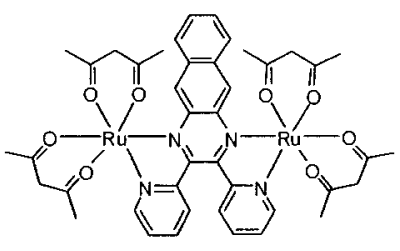

3.12

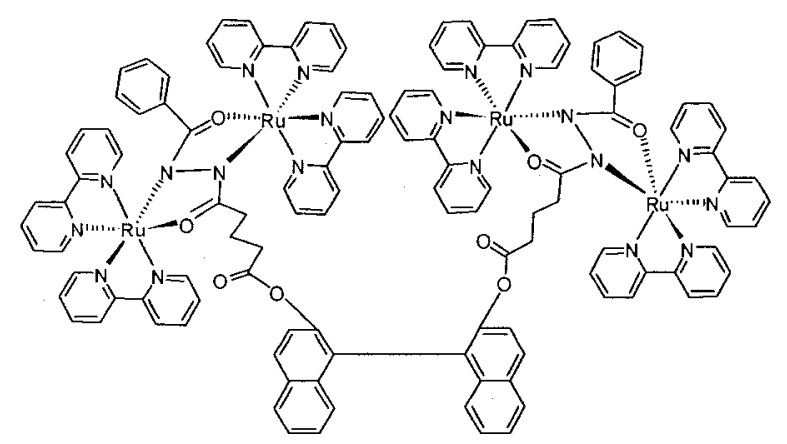

3.13

Figure 3.2. Structures of ruthenium complexes 3.1-3.13.

Among all the ligands used (Figure 3.3), bpy, acac and PBIm-H are commercially availabe. 2-Pyridin-2-yl-1H-phenanthro[9,10-d]imidazole (PHPI) was synthesized by condensation of phenanthrene-9,10-dione with pyridine-2-carbaldehyde in refluxing glacial acetic acid containing ammonium acetate. $^{2}$ 2,3-Diaminonaphthalene, the starting material for dpb, was prepared from the reaction of 2,3-dihydroxynaphthalene with aqueous ammonia in an 
autoclave at $180{ }^{\circ} \mathrm{C}$ with a yield of $50 \%-60 \%$. As described in the literature, ${ }^{3}$ condensation of 2,3-diaminonaphthalene with 2,2'-pyridil in absolute ethanol or acetic acid afforded dpb in a yield of $70 \%-80 \%$. The symmetric DCH ligand (ph-DCH-ph) was prepared from the reaction of benzoic hydrazide with benzoyl chloride. Reaction of glutaric anhydride with benzoic hydrazide gave the asymmetric DCH ligand BA-DCH-ph.

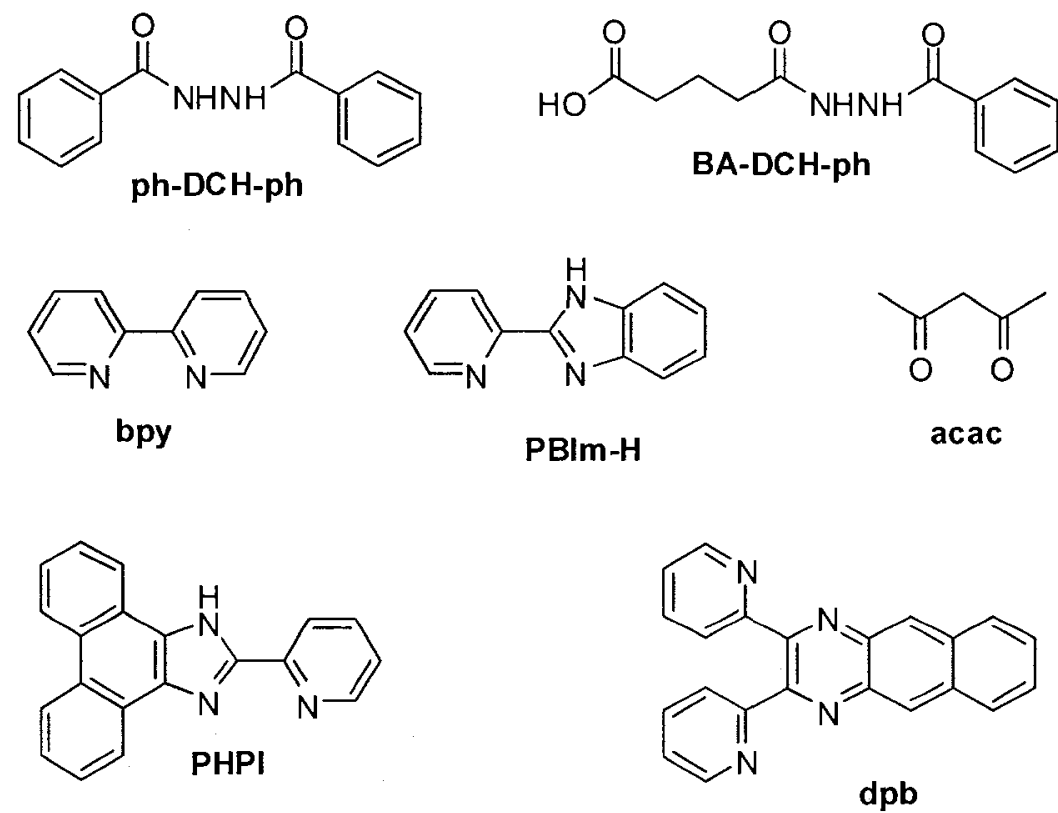

Figure 3.3. Structures of ligands.

The synthesis of complexes is shown in Scheme 3.2. Mono-nuclear and dinuclear ruthenium complexes were synthesized by reaction of peripheral ligands with cis- $\mathrm{Ru}(\mathrm{bpy})_{2} \mathrm{Cl}_{2} \cdot 2 \mathrm{H}_{2} \mathrm{O}$, cis- $\mathrm{Ru}(\mathrm{PBIm}-\mathrm{H})_{2} \mathrm{Cl}_{2} \cdot 2 \mathrm{H}_{2} \mathrm{O}$ or $\mathrm{Ru}(\mathrm{acac})_{2}\left(\mathrm{CH}_{3} \mathrm{CN}\right)_{2}$. $\mathrm{Ru}(\mathrm{acac})_{2}\left(\mathrm{CH}_{3} \mathrm{CN}\right)_{2}$ was synthesized according to the literature method, ${ }^{4}$ by reduction of tris(acetylacetonato)ruthenium with zinc amalgam in aqueous 
$\mathrm{CH}_{3} \mathrm{CN}$. cis- $\mathrm{Ru}(\mathrm{PBIm}-\mathrm{H})_{2} \mathrm{Cl}_{2} \cdot 2 \mathrm{H}_{2} \mathrm{O}$ was prepared in the same procedure as for the synthesis of $c i s-\mathrm{Ru}(\mathrm{bpy})_{2} \mathrm{Cl}_{2} \cdot 2 \mathrm{H}_{2} \mathrm{O} .^{5}$ cis-Ru(bpy $)_{2} \mathrm{Cl}_{2} \cdot 2 \mathrm{H}_{2} \mathrm{O}$ reacted with one equivalent of PBIm-H, PHPI and dpb to produce complexes 3.2, 3.3 and 3.6, respectively or a half equivalent of $\mathrm{dpb}$ to form complex 3.11 . cis- $\mathrm{Ru}(\mathrm{PBIm}-\mathrm{H})_{2} \mathrm{Cl}_{2} \cdot 2 \mathrm{H}_{2} \mathrm{O}$ reacted with one equivalent of PHPI, acac and dpb to produce complexes 3.4, 3.5 and 3.7, respectively or a half equivalent of dpb to form complex 3.10. The dpb ligand reacted with one equivalent or two equivalents of $\mathrm{Ru}(\mathrm{acac})_{2}\left(\mathrm{CH}_{3} \mathrm{CN}\right)_{2}$ to afford complexes 3.8 and 3.12, respectively.

The dinuclear ruthenium complex 3.9 was prepared according to the reported procedure, ${ }^{6}$ by reacting $c i s-\mathrm{Ru}(\mathrm{bpy})_{2} \mathrm{Cl}_{2} \cdot 2 \mathrm{H}_{2} \mathrm{O}$ with ph-DCH-ph in aqueous ethanol. For intermediate complex $\mathbf{A}$, the reaction mixture needs to be acidified with dilute $\mathrm{HCl}$ solution to free up the carboxylic acid before exchanging the counterions with $\mathrm{PF}_{6}{ }^{-}$. Esterification of complex $\mathbf{A}$ with 1,1'-bi(2-naphthol) afforded complex 3.13 with a yield of $74 \%$, using a known coupling method. ${ }^{7}$ All the complexes were purified by column chromatography on neutral aluminum oxide with $\mathrm{CH}_{3} \mathrm{CN}$ /toluene as eluent. 
Mono-nuclear complexes

$\mathrm{RuL}_{2} 2 \mathrm{H}_{2} \mathrm{O}+\mathrm{L}^{\prime} \stackrel{\text { EtOH or ethylene glycol }}{\longrightarrow} \mathrm{RuL}_{2} \mathrm{~L}^{\prime}$

Dinuclear complexes

$2 \mathrm{RuL}_{2} 2 \mathrm{H}_{2} \mathrm{O}+\mathrm{L}^{\prime}$ EtOH or ethylene glycol $-\mathrm{RuL}_{2} \mathrm{~L}^{\prime} \mathrm{RuL} 2$

Branched complex 3.13 BA-DCH-ph + $\mathrm{Ru}(\mathrm{bpy})_{2} \mathrm{Cl}_{2}$

Scheme 3.2. Synthesis of ruthenium complexes.

The structures of all the ligands were confirmed by ${ }^{1} \mathrm{H}$ NMR, ${ }^{13} \mathrm{C}$ NMR and EI-MS. With respect to the NMR of complexes, a small residue of oxidized paramagnetic complexes and the overlap of the protons in the aromatic region made it impossible to make full spectral assignments. ESI-MS is useful to confirm the complex structures. Figure 3.4 shows the mass spectrum of complex 3.13. The calculated molecular mass of complex 3.5 is 2981. A loss of $4 \mathrm{PF}_{6}^{-}$anions gave a molecular ion peak at $m / z 600.4(100 \%)$. Other peaks at $m / z 850.0\left[\mathrm{M}-3 \mathrm{PF}_{6}\right]^{3+}$ $(4.1 \%)$ and $1344.1\left[\mathrm{M}-2 \mathrm{PF}_{6}\right]^{2+}(0.4 \%)$ were also observed. 


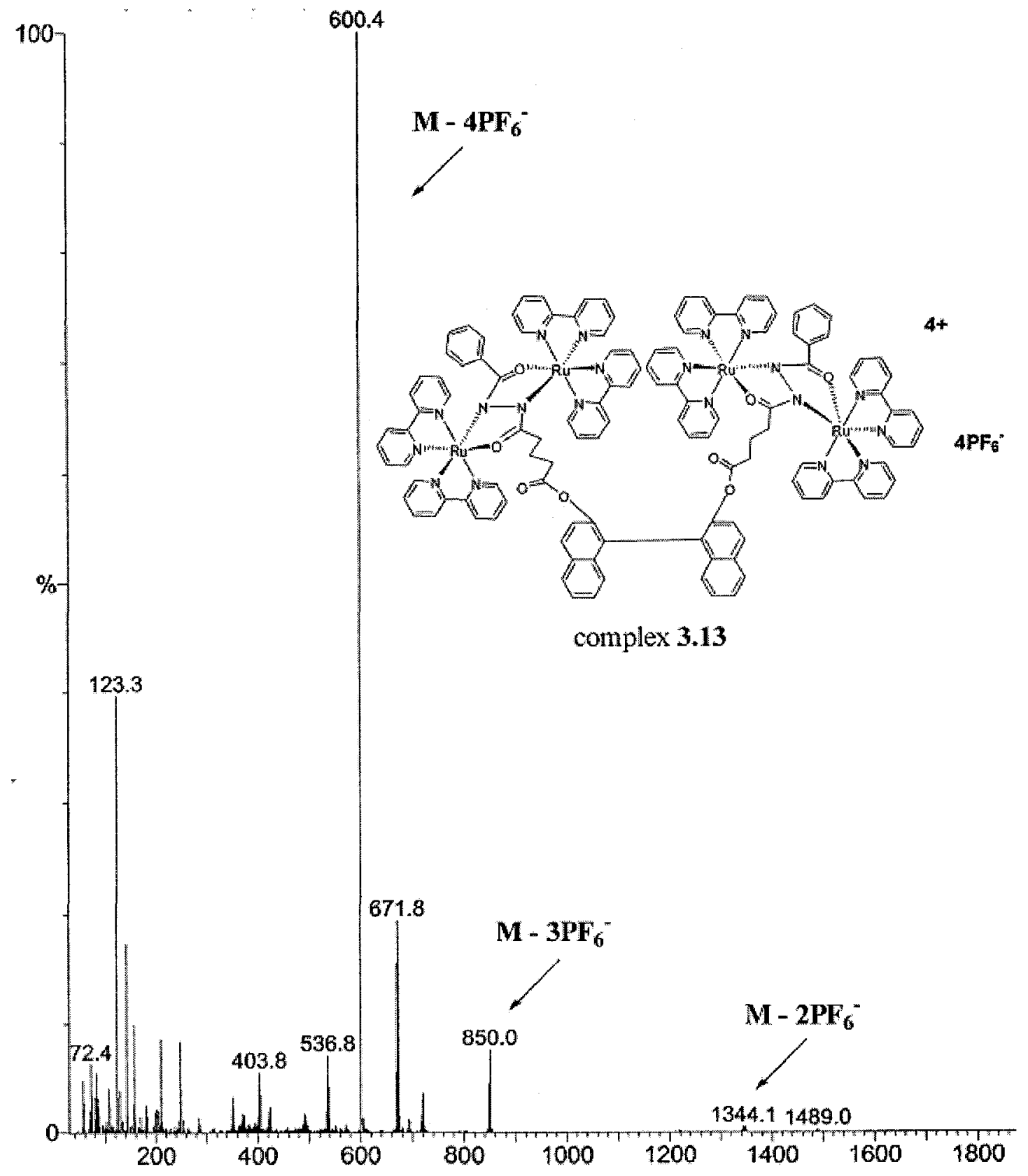

Figure 3.4. Mass spectrum of complex 3.13. 


\subsection{Results and discussions}

\subsubsection{Optical properties}

Complexes 3.1-3.13 have a good solubility in common organic solvents, such as $\mathrm{CH}_{3} \mathrm{CN}$, acetone, methanol, THF and DMF. Figure 3.5 shows the UV-vis-NIR absorption spectra of complexes 3.1-3.13 measured in $\mathrm{CH}_{3} \mathrm{CN}$ $\left(10^{-5} \mathrm{M}\right)$. Only the transitions attributed to the lowest energy are displayed in the spectra and other transitions, such as ligand $\pi \rightarrow \pi^{*}$ in the UV region, are not included.

The absorption spectra of complexes 3.1-3.13 show a strong metal-to-ligand-charge-transfer (MLCT) transition band in the visible region, which is typical for ruthenium-pyridyl complexes. The MLCT bands corresponding to complexes $\mathbf{3 . 8}$ and $\mathbf{3 . 1 2}$ are red shifted into the NIR spectral region and much broader than others. A red shift of MLCT transitions is observed from $450 \mathrm{~nm}$ for complex 3.1 to $760 \mathrm{~nm}$ for complex $\mathbf{3 . 1 2}$.

Figure 3.6 shows the PL spectra of complexes 3.1-3.13 measured in $\mathrm{CH}_{3} \mathrm{CN}\left(10^{-5} \mathrm{M}\right)$ under ambient conditions. The emission wavelengths of complexes 3.1-3.11 gradually shift from $620 \mathrm{~nm}$ for complex 3.1 to $1100 \mathrm{~nm}$ for complex 3.11, when excited at the MLCT absorption wavelength. The same red-shift trend was also observed for their absorption wavelengths. The red shift of absorption and PL is in line with the decrease of energy gaps of ruthenium complexes (Figure 3.8 and Table 3.1). 


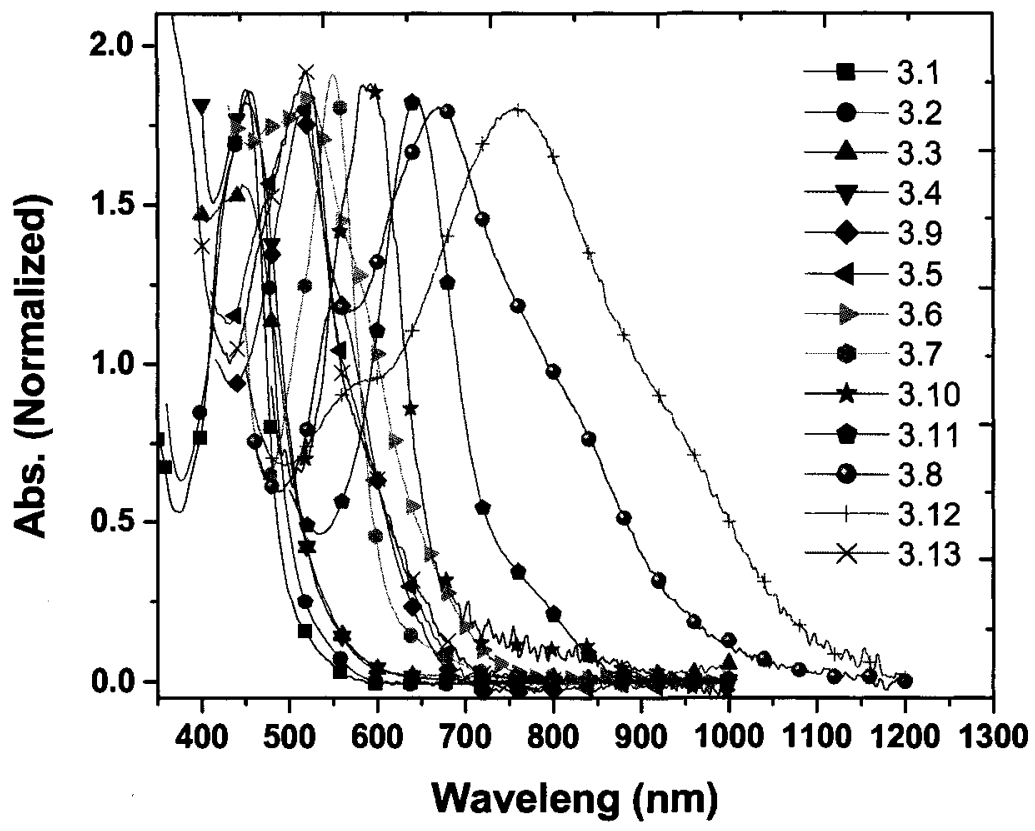

Figure 3.5. Absorption spectra of complexes 3.1-3.13 in $\mathrm{CH}_{3} \mathrm{CN}\left(10^{-5} \mathrm{M}\right)$.

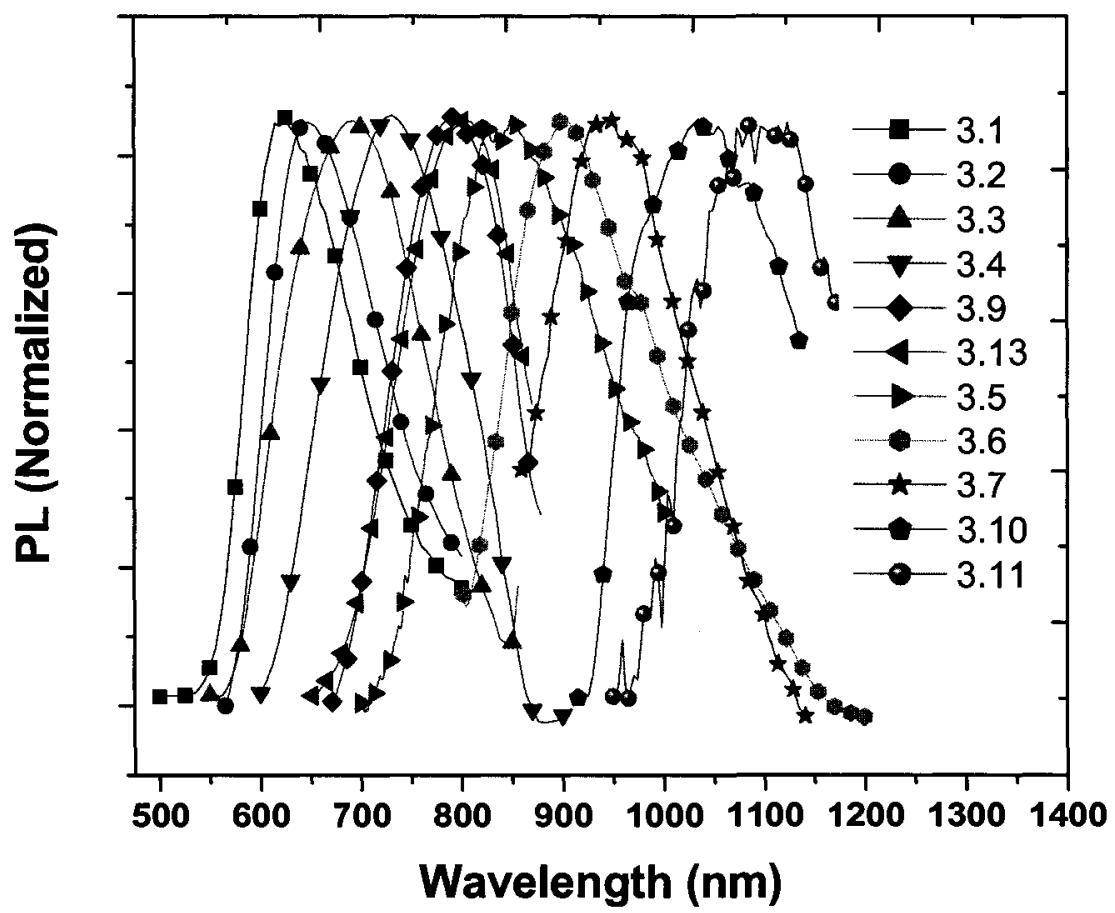

Figure 3.6. PL spectra of complexes 3.1-3.11 in $\mathrm{CH}_{3} \mathrm{CN}\left(10^{-5} \mathrm{M}\right)$. 


\subsubsection{Electrochemical properties}

Cyclic voltammetry was taken to characterize the electrochemical properties of the complexes 3.1-3.13. The electrochemistry of this type of metal complexes is well understood, involving the metal-localized oxidation and ligand-localized reduction. It is noticed that all mono-nuclear complexes exhibit one-electron oxidation process, assigned to the $\mathrm{Ru}^{\mathrm{II}} / \mathrm{Ru}^{\mathrm{III}}$ redox couples (complexes 3.1-3.8) and two oxidation processes are observed in the dinuclear ruthenium complexes $3.9-3.13$, corresponding to $\mathrm{Ru}{ }^{\mathrm{II}}-\mathrm{BL}-\mathrm{Ru}{ }^{\mathrm{II}} \leftrightarrow \mathrm{Ru}^{\mathrm{II}}-\mathrm{BL}-\mathrm{Ru}^{\mathrm{III}}$ $\leftrightarrow \mathrm{R} \mathrm{u}^{\mathrm{III}}-\mathrm{BL}-\mathrm{Ru} \mathrm{u}^{\mathrm{III}}(\mathrm{BL}=$ bridging ligand $)$

Figure 3.7 shows the cyclic voltammograms of complexes 3.6 and 3.9 as examples of mono-nuclear and dinuclear complexes, respectively. For complex 3.6, it displays three reversible reduction waves with the first one being assigned to a bridging ligand (dpb) reduction, due to easier reduction of dpb with a slightly stabilized dpb $\pi^{*}$ oribital, ${ }^{8}$ than bpy. The second and third waves are assigned to sequential reductions of the two bpy ligands. For complex 3.9, the reduction at $-1.4 \mathrm{~V}$ is ascribed to the one-electron reduction of the peripheral bpy ligand.

Moreover, the CV method was employed to estimate HOMO and LUMO energy levels of the complexes according to the empirical equations $E_{\mathrm{HOMO}}=E^{o x}$ $+4.40 \mathrm{eV}$ and $E_{\mathrm{LUMO}}=E^{r e d}+4.40 \mathrm{eV}$, where $E^{o x}$ and $E^{\text {red }}$ are onset potentials for the oxidation and reduction processes, relative to NHE. Herein the HOMO is a ruthenium based $\mathrm{d} \pi$ orbital and the LUMO is a ligand based $\pi^{*}$ orbital. The electrochemical data and energy levels of complexes are summarized in Table 3.1. 


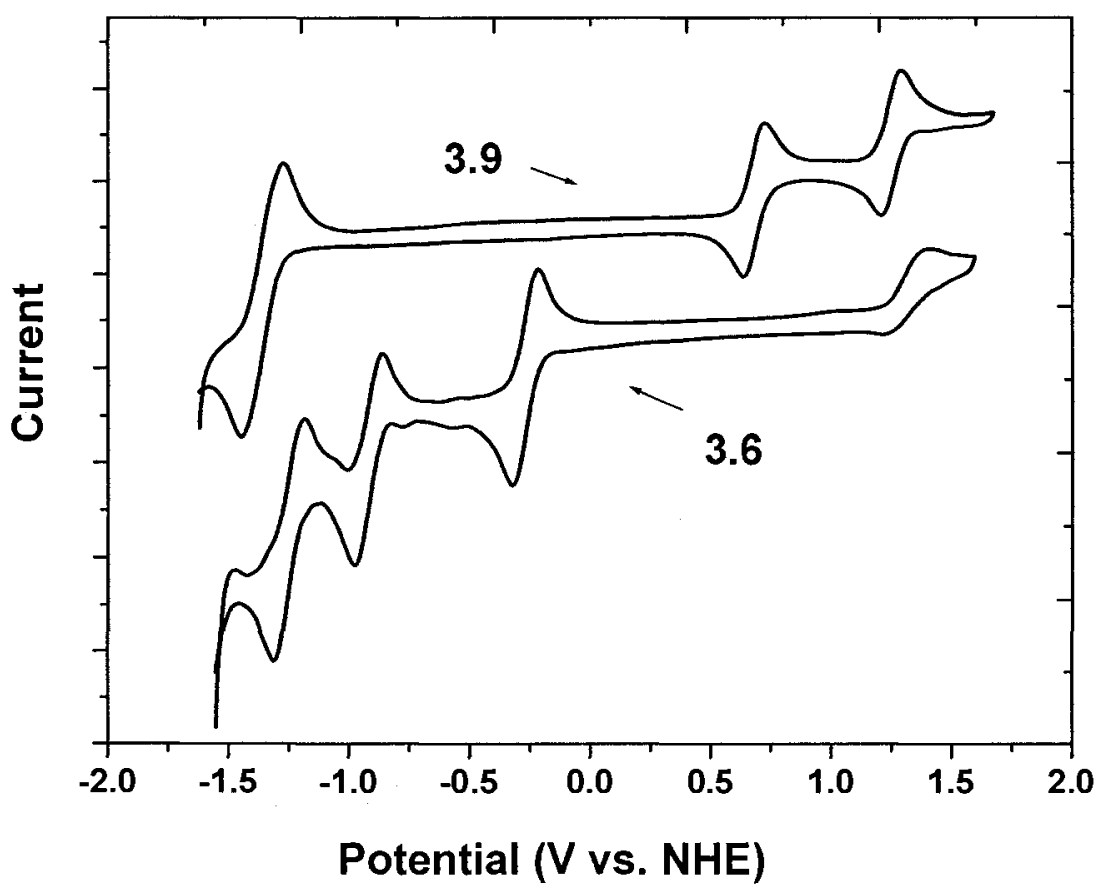

Figure 3.7. $\mathrm{CV}$ of complexes 3.6 and 3.9 in $0.1 \mathrm{M} \mathrm{NEt}_{4} \mathrm{ClO}_{4} / \mathrm{CH}_{3} \mathrm{CN}$ at a scan rate of $100 \mathrm{mVs}^{-1}$.

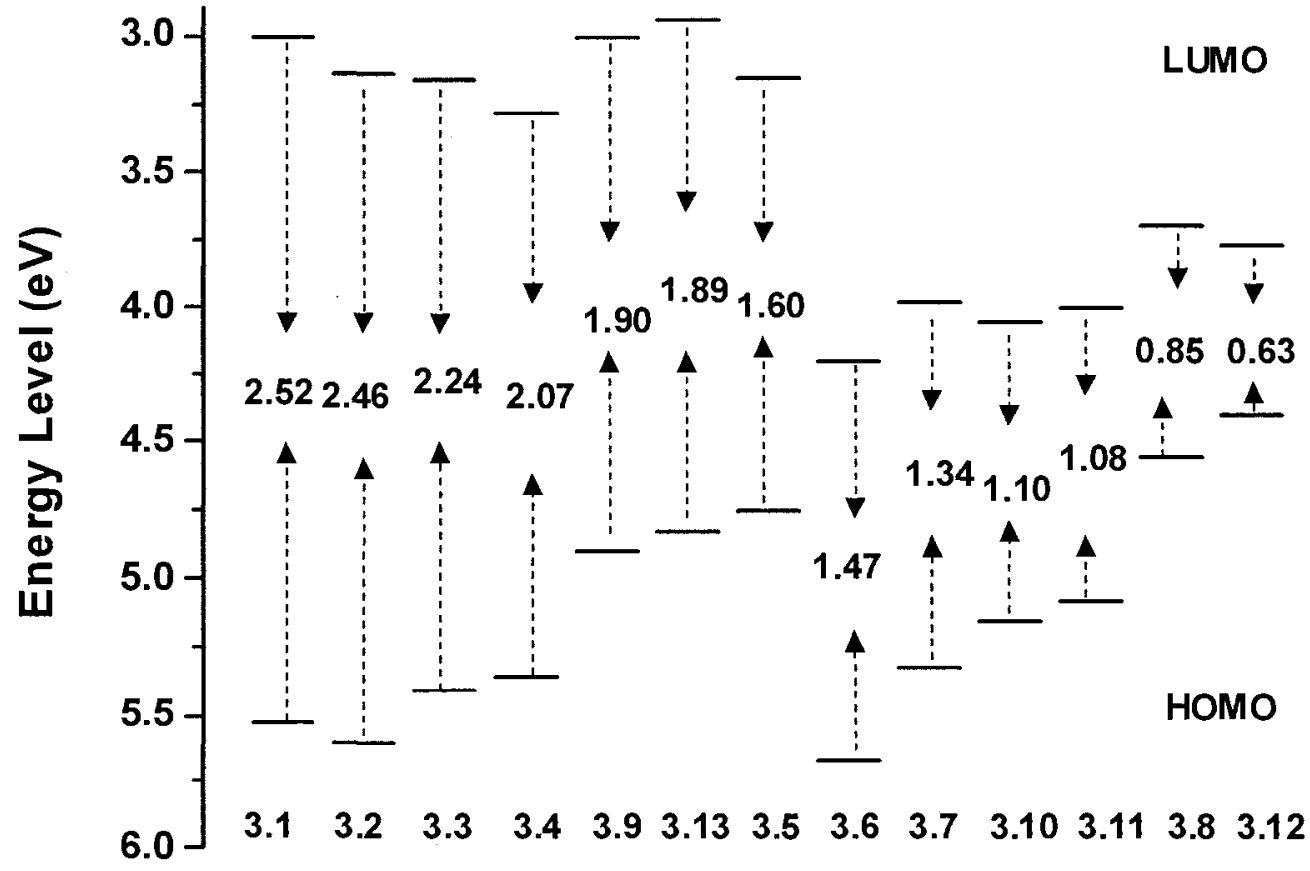

Figure 3.8. The LUMO and HOMO energy levels of complexes 3.1-3.13. 
Table 3.1. The optical properties, electrochemical data and energy levels of complexes.

\begin{tabular}{cccccccc}
\hline Complex & $\begin{array}{c}\mathrm{UV}, \\
\lambda_{\max } \\
(\mathrm{nm})\end{array}$ & $\begin{array}{c}\mathrm{PL}, \\
\lambda_{\max } \\
(\mathrm{nm})\end{array}$ & $\begin{array}{c}\mathrm{E}_{\mathrm{ox}}{ }^{\mathrm{a}} \\
(\mathrm{V})\end{array}$ & $\begin{array}{c}\mathrm{E}_{\text {red }}{ }^{\mathrm{a}} \\
(\mathrm{V})\end{array}$ & $\begin{array}{c}\mathrm{HOMO}^{\mathrm{b}} \\
(\mathrm{eV})\end{array}$ & $\begin{array}{c}\mathrm{LUMO}^{\mathrm{b}} \\
(\mathrm{eV})\end{array}$ & $\begin{array}{c}\mathrm{E}_{\mathrm{g}} \\
(\mathrm{eV})\end{array}$ \\
\hline $\mathbf{3 . 1}$ & 450 & 620 & 1.12 & -1.40 & 5.52 & 3.00 & 2.52 \\
$\mathbf{3 . 2}$ & 454 & 645 & 1.20 & -1.26 & 5.60 & 3.14 & 2.46 \\
$\mathbf{3 . 3}$ & 450 & 690 & 1.00 & -1.24 & 5.40 & 3.16 & 2.24 \\
$\mathbf{3 . 4}$ & 450 & 730 & 0.95 & -1.17 & 5.35 & 3.28 & 2.07 \\
$\mathbf{3 . 9}$ & 518 & 790 & $0.50,1.10$ & -1.40 & 4.90 & 3.00 & 1.90 \\
$\mathbf{3 . 1 3}$ & 519 & 800 & $0.43,1.01$ & -1.46 & 4.83 & 2.94 & 1.89 \\
$\mathbf{3 . 5}$ & 522 & 850 & 0.35 & -1.25 & 4.75 & 3.15 & 1.60 \\
$\mathbf{3 . 6}$ & 550 & 900 & 1.27 & -0.20 & 5.67 & 4.20 & 1.47 \\
$\mathbf{3 . 7}$ & 565 & 945 & 0.92 & -0.42 & 5.32 & 3.98 & 1.34 \\
$\mathbf{3 . 1 0}$ & 590 & 1040 & $0.75,1.25$ & -0.35 & 5.15 & 4.05 & 1.10 \\
$\mathbf{3 . 1 1}$ & 643 & 1100 & $0.68,1.22$ & -0.40 & 5.08 & 4.00 & 1.08 \\
$\mathbf{3 . 8}$ & 670 & - & 0.15 & -0.70 & 4.55 & 3.70 & 0.85 \\
$\mathbf{3 . 1 2}$ & 760 & - & $0,0.41$ & -0.63 & 4.40 & 3.77 & 0.63 \\
\hline
\end{tabular}

${ }^{\text {a }}$ Cyclic voltammetry performed at a $100 \mathrm{mV} / \mathrm{s}$ scan rate in $\mathrm{CH}_{3} \mathrm{CN} / 0.1 \mathrm{M}$ TBAH.

${ }^{\mathrm{b}}$ Energy levels estimated according to $E_{\mathrm{HOMO}}=E^{o x}+4.40 \mathrm{eV}$ and $E_{\mathrm{LUMO}}=E^{r e d}+$ $4.40 \mathrm{eV}$. 
Among all these complexes, the dpb ligand with low-energy $\pi^{*}$ orbital can effectively lower the LUMO level of the complexes, in comparison with the more common ligand bpy. As can be seen from the reduction potentials for complexes 3.6-3.8 and 3.10-3.12 (Table 3.1), their LUMO levels range from 3.70 to $4.20 \mathrm{eV}$. In addition, electron-rich ligands such as acac, PBIm-H, and PHPI are stronger $\sigma$ donors than bpy, thus being able to stabilize the $\mathrm{Ru}^{\mathrm{III}}$ state to a greater extent than bpy does. The increased donor strength will lead to an increase in the $d \pi$ orbital energies in ruthenium complexes and lower the oxidization potential of ruthenium complexes. ${ }^{9}$ Thus, acac, PBIm-H and PHPI are able to increase the HOMO levels of the complexes. Moreover, the increase of HOMO energy correlates with the number of electron donor ligands in the complexes. ${ }^{10}$ With respect to complex $\mathbf{3 . 1}$, complexes 3.4-3.5, 3.7 and $\mathbf{3 . 1 0}$ with PBIm-H as peripheral ligands, and complexes 3.8 and $\mathbf{3 . 1 2}$ with acac as peripheral ligands instead of bpy display the higher HOMO levels (Figure 3.8 and Table 3.1).

It is noticed that for a bridged bimetallic complex, the oxidation potential of the complex in the $\mathrm{Ru}^{\mathrm{II}} / \mathrm{Ru}^{\mathrm{III}}$ state decreases as a result of the presence of the second electron deficient metal center and electronic coupling of the two metal centers through the bridging ligand. Thus, for complexes 3.9-3.12, the HOMO levels increase significantly relative to the corresponding mono-nuclear complexes 3.6-3.8.

By employing different ligands that could increase the HOMO energy levels or decrease the LUMO energy levels, a gradual change of the band gap 
from $2.52 \mathrm{eV}$ for complex 3.1 to $0.63 \mathrm{eV}$ for complex 3.12 was achieved (Figure 3.8 and Table 3.1). The decrease in the energy gap of these complexes should result in the red shift of PL and EL. Indeed, NIR emission was realized with complexes 3.4-3.11 and 3.13. In addition, the low-energy edge of the emission spectra of complexes $\mathbf{3 . 8}$ and $\mathbf{3 . 1 2}$ should be above $1400 \mathrm{~nm}$, as estimated from their bandgap energies ( $\mathrm{PL}_{\text {onset }}=1240 /$ bandgap). However, their PL couldn't be detected, likely because of some dominant non-radiative processes. ${ }^{11}$

\subsubsection{Electroluminescent properties}

To investigate EL properties of these complexes, a single LEC device with a configuration of indium tin oxide (ITO)/complex $(100 \mathrm{~nm}) / \mathrm{Au}(100 \mathrm{~nm})$ was used. The device was fabricated by spin-coating a solution of the complex in $\mathrm{CH}_{3} \mathrm{CN}(30 \mathrm{mg} / \mathrm{mL})$ onto ITO glass and then vacuum depositing $\mathrm{Au}$ electrode onto the complex film.

Figure 3.9 shows the EL spectra of complexes 3.1-3.3, 3.5-3.7, 3.9-3.10 and 3.13, which coincide well with their PL spectra, indicating that they both have the same molecular origin and correspond to the same electronic transition (MLCT). The $L-V-t$ curves of complex 3.1-3.3, 3.5-3.7, 3.9 and 3.13 are shown in Figure 3.10 and the device outputs and efficiencies are summarized in Table 3.2. It can be seen that with an increase in the emission wavelength, the device output decreases noticeably, from $475 \mathrm{~mW} / \mathrm{Sr} \cdot \mathrm{m}^{2}$ (complex 3.1) to $4 \mathrm{~mW} / \mathrm{Sr} \cdot \mathrm{m}^{2}$ (complex 3.6). The external quantum efficiency $\left(\eta_{\mathrm{Ph}}\right)$ also decreases from $0.713 \%$ to $0.006 \%$, 
going from complex 3.1 to complex 3.6, respectively. Although the brightness and efficiency of the LEC containing complex 3.10 were not able to be measured under ambient conditions due to some non-radiative processes, ${ }^{11}$ it is still remarkable to realize the $\mathrm{PL}$ and $\mathrm{EL}$ at the wavelength above $1000 \mathrm{~nm}$, compared to other PL- and EL-active dinuclear ruthenium complexes. ${ }^{12}$

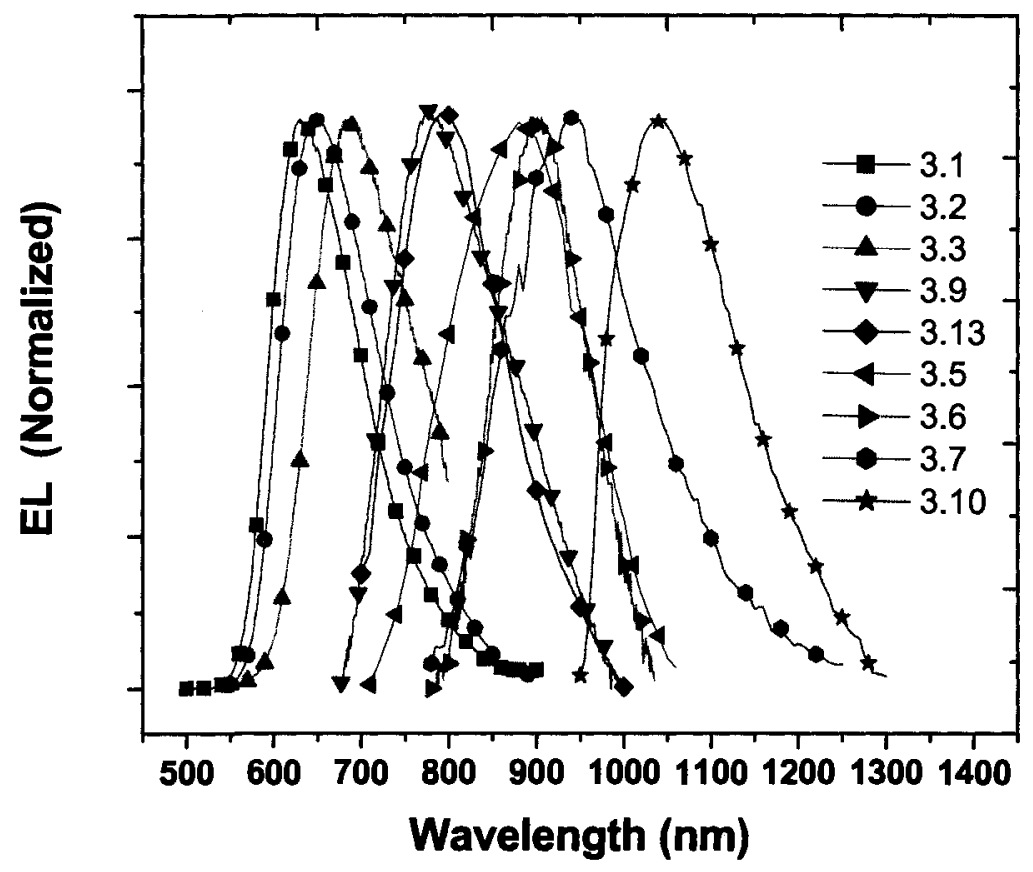

Figure 3.9. EL spectra of the LEC devices based on ruthenium complexes.

The stability of LECs based on complexes 3.1 and 3.2 is very sensitive to the operating voltage and device degradation quickly takes place at higher voltage. As shown in Figure 3.10 (a) and (b), the decay of brightness of the devices based on complexs 3.1 and 3.2 is rapid at $5 \mathrm{~V}$.

LECs in general exhibit a delay between the time when the device is turned on and the time when a steady state light emission is reached. This time 
delay (reponse time) is caused by the redistribution of ions that must occur to support the hole (oxidation) and electron (reduction) injection at the electrodes. ${ }^{6 c}$ The response time range from $5 \mathrm{~s}(6 \mathrm{~V})$ for complex 3.6 (Figure $3.10 \mathrm{e}$ ) to $180 \mathrm{~s}$ (4V) for complex 3.2 (Figure 3.10b), according to the applied voltages. The steady state is reached in a shorter time at the higher voltage because of the stronger driving force for the ions.

Relative to others, complexes 3.5 and 3.7 with PBIm-H bidentate ligand need a higher driving voltage (14 $\mathrm{V}$ for complex 3.5 and $15 \mathrm{~V}$ for complex 3.7), presumably due to their lower ionic conductivity, which could be supported by the lower current at higher voltage. The more twisted configuration of complexes with PBIm-H bidentate ligand, in comparison with those complexes with bpy bidentate ligand, might result in a lower ionic conductivity. Using small and mobile counterions such as $\mathrm{BF}_{4}^{-}$instead of large anion $\mathrm{PF}_{6}^{-}$could improve the ionic conductivity, which was revealed by other researchers. ${ }^{6 \mathrm{~b}, 6 \mathrm{~s}}$

In addition, it can be seen that the device based on complex 3.13 shows a higher luminance. The maximum brightness reaches $240 \mathrm{mV} / \mathrm{Sr}^{2} \mathrm{~m}^{2}$ at $6 \mathrm{~V}$, which is about a factor of 3 brighter than that of the device based on complex $\mathbf{3 . 9}$ with a value of $69 \mathrm{mV} / \mathrm{Sr} \cdot \mathrm{m}^{2}$ at $5 \mathrm{~V}$. The device based on complex 3.13 also shows a higher external quantum efficiency of $0.025 \%$ than the device based on complex 3.9. Compared to a maximum external quantum efficiency of $0.013 \%$ for the device based on complex 3.9, the EL efficiency of the device based on complex $\mathbf{3 . 1 3}$ is enhanced by a factor of 2 . This may be attributed to a better film quality of the 
branched molecule, complex 3.13, relative to complex 3.1 .

Table 3.2. Electroluminescent properties of complexes.

\begin{tabular}{ccccc}
\hline Complex & EL, $\lambda_{\max }$ & Brightness & $\eta_{\mathrm{ph}}^{\mathrm{b}}$ & $\eta_{\text {power }}{ }^{\mathrm{b}}$ \\
& $(\mathrm{nm})$ & $\left(\mathrm{mV} / \mathrm{Sr}^{2} \mathrm{~m}^{2}\right)(\mathrm{V})^{\mathrm{a}}$ & $(\%)$ & $(\%)$ \\
$\mathbf{3 . 1}$ & 630 & $475(5)$ & 0.713 & 0.327 \\
$\mathbf{3 . 2}$ & 650 & $173(5)$ & 0.195 & 0.090 \\
$\mathbf{3 . 9}$ & 690 & $60(5)$ & 0.123 & 0.043 \\
$\mathbf{3 . 5}$ & 780 & $69(5)$ & 0.013 & 0.004 \\
$\mathbf{3 . 6}$ & 880 & $9(14)$ & 0.075 & 0.007 \\
$\mathbf{3 . 7}$ & 900 & $4(6)$ & 0.006 & 0.001 \\
$\mathbf{3 . 1 0}$ & 1040 & $5(15)$ & 0.030 & 0.003 \\
\hline $\mathbf{3 . 1 3}$ & 800 & $240(6)$ & 0.025 & 0.007 \\
\hline
\end{tabular}

${ }^{a}$ Voltage at which the brightness was measured. ${ }^{b}$ external quantum efficiency $\left(\eta_{\mathrm{ph}}\right)$ and power conversion efficiency $\left(\eta_{\text {power }}\right)$ of the devices were calculated based on a dot light source system. 

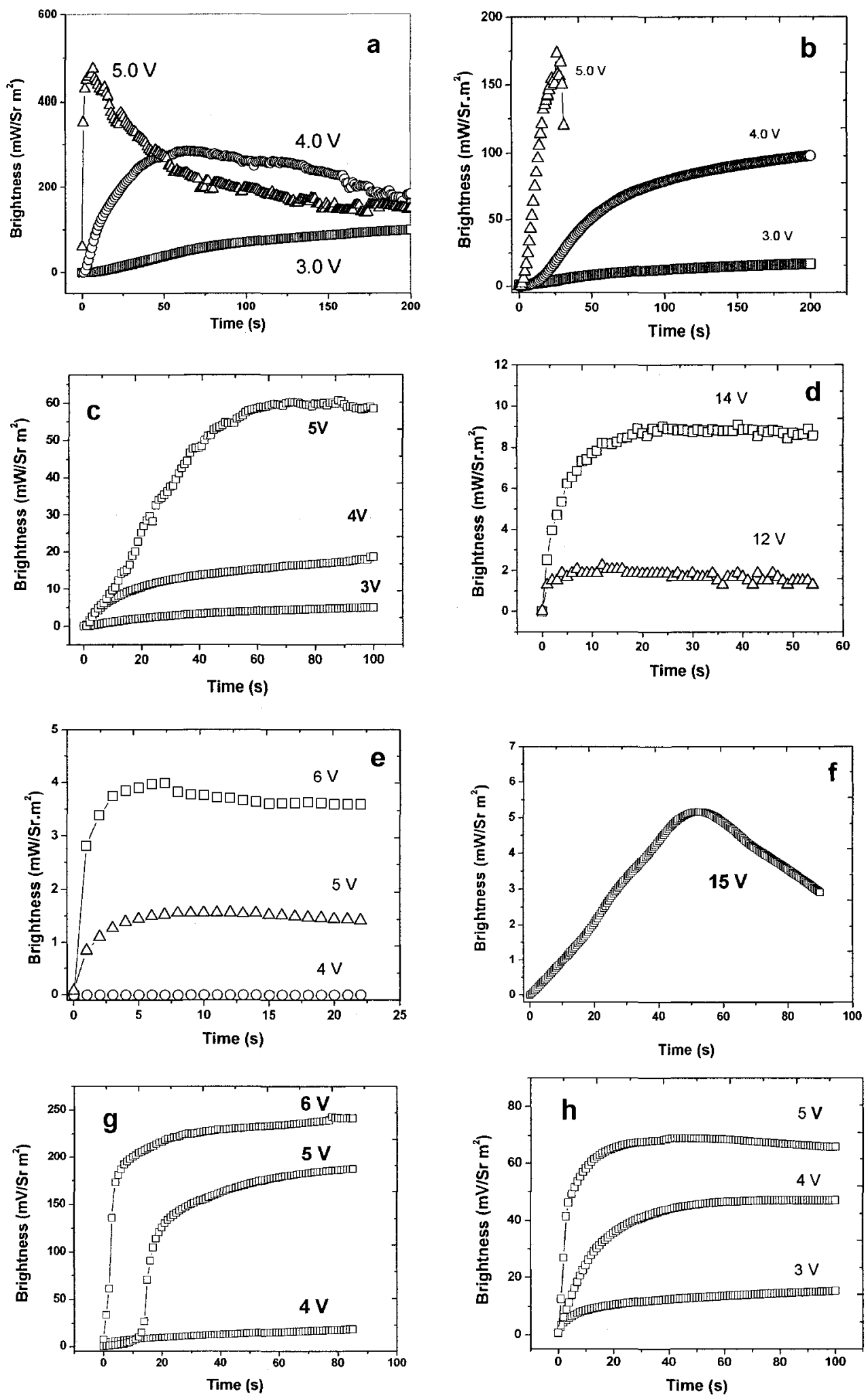

Figure 3.10. The $L-V-t$ curves of the devices (a) complex 3.1 (b) complex 3.2 (c) complex 3.3 (d) complex 3.5 (e) complex 3.6 (f) complex 3.7 (g) complex $3.13(\mathrm{~h})$ complex 3.9. 


\subsection{Conclusion}

Since the energy levels of ruthenium complexes relate to their optoelectronic properties, ability of systematically and chemically varying the LUMO and HOMO energy of these complexes is shown to extremely useful in adjusting and controlling the absorption and emission properties. The LUMO and HOMO levels are adjusted through the use of different ligands. Among them, dpb is shown to be very effective to lower the LUMO level. The electron-rich ligands acac, PBIm-H, and PHPI and dinuclear configuration are proved to be able to increase the HOMO level of the ruthenium complexes. By using this strategy, tunable PL from 620 to $1100 \mathrm{~nm}$ and EL from 630 to $1040 \mathrm{~nm}$ have been realized. This finding invites exploration of a broader range of low band-gap (e.g., 0.7-1.2 $\mathrm{eV)}$ ruthenium complex materials for NIR light-emitting applications in telecommunication (1300-1600 nm) and bio-imaging (1000-1300 nm).

\subsection{Experiments}

\section{Materials}

Benzoic hydrazide, benzoyl chloride, glutaric anhydride, terephthaloyl chloride, phenanthrene-9,10-dione, 2,2'-pyridil, 2,2'-dipyridyl, pyridine-2-carbaldehyde, 2,3-dihydroxynaphthalene, acetylacetone, 2,3-diaminonaphthalene, and 2-(2-pyridyl)benzimidazole were purchased from Aldrich Chemicals Inc., Canada, and used as received. $\mathrm{RuCl}_{3} \cdot 3 \mathrm{H}_{2} \mathrm{O}$ was purchased from Pressure Chemicals Co. and used as received. $\mathrm{Ru}(\mathrm{bpy})_{3} \mathrm{Cl}_{2}$ was 
purchased from Aldrich Chemicals Inc., Canada, and converted to $\mathrm{Ru}(\mathrm{bpy})_{3}\left(\mathrm{PF}_{6}\right)_{2}$ (complex 3.6). All the solvents were ACS reagent grade or higher and used as received.

\section{Measurements}

The absorption spectrum of each of the complexes used in this study was taken in $\mathrm{CH}_{3} \mathrm{CN}$ at room temperature using a Perkin Elmer Lambda 900 UV-vis-NIR spectrophotometer. The PL spectra of the dilute solution $\left(10^{-5} \mathrm{M}\right)$ in $\mathrm{CH}_{3} \mathrm{CN}$ were obtained by using a PTI spectrophotometer.

Electrochemical experiments were carried out on a Bio-Analytical Systems $100 \mathrm{~W} \mathrm{~B} / \mathrm{W}$ electrochemical station. The three-electrode system consisted of platinum working electrode, platinum wire auxiliary electrode and silver wire reference electrode. All the reported potentials were referenced to the normal hydrogen electrode (NHE) and standardized with ferrocene. All the solutions were deoxygenated with argon prior to electrochemical measurements. $0.1 \mathrm{M} \mathrm{NEt}_{4} \mathrm{ClO}_{4}$ $/ \mathrm{CH}_{3} \mathrm{CN}$ was used as a supporting electrolyte solution in all analyses. A scan rate of $100 \mathrm{mVs}^{-1}$ was used.

Melting points were measured on a Fisher-Jones melting point apparatus and are uncorrected. The University of Ottawa Regional Mass Spectrometry Centre performed the low-resolution EI and ESI mass spectroscopy. The peaks are reported as $\mathrm{m} / \mathrm{z}$ (\% intensity relative to the base peak). The ${ }^{1} \mathrm{H}$ and ${ }^{13} \mathrm{C} N M R$ spectra were carried on Bruker Avance-300 and chemical shifts were reported in 
ppm using tetramethylsilane (TMS) as an internal standard.

The EL spectra were measured using a PTI spectrophotometer. The brightness $\sim$ current $\sim$ time characteristics of the devices under different voltage were measured using Keithley 2420 sourcemeter, Newport $1830 \mathrm{c}$ powermeter and Si detector together. The brightness and quantum efficiencies were calculated using a dot-light source model.

\section{Ligand Synthesis}

\section{1,2-Dibenzoylhydrazide}

A solution of benzoic hydrazide $(2.10 \mathrm{~g}, 16.6 \mathrm{mmol})$ and sodium carbonate $(1.60 \mathrm{~g}, 16.6 \mathrm{mmol})$ in $30 \mathrm{~mL}$ of THF and $20 \mathrm{~mL}$ of water was added to a solution of benzoyl chloride $(2.6 \mathrm{~g}, 18 \mathrm{mmol})$ in $30 \mathrm{~mL}$ of THF at $0^{\circ} \mathrm{C}$. The mixture was stirred for $3 \mathrm{~h}$. The white precipitate was collected by filtration, washed three times with $25-\mathrm{mL}$ portions of THF and dried overnight in vacuum. The yield was $3.0 \mathrm{~g}(75 \%) .{ }^{1} \mathrm{H}$ NMR $\left(300 \mathrm{MHz}, \mathrm{d}_{6}-\mathrm{DMSO}\right): \delta 7.51(\mathrm{t}, 4 \mathrm{H}), 7.58(\mathrm{~m}, 2 \mathrm{H}), 7.92$ (d, 4H), 10.54 (s, 2H); ${ }^{13} \mathrm{C}$ NMR (75 MHz, d $\mathrm{d}_{6}$-DMSO): $\delta 127.8,128.9,131.9$, 133.7, 165.7; EI-MS $m / z$ (\% relative intensity): $240\left(5.1, \mathrm{M}^{+}\right), 222(6.1), 165$ (6.9); $\mathrm{mp} 238-239^{\circ} \mathrm{C}$.

\section{1-Benzoyl-2-(4-carboxybutyryl)-hydrazine}

A solution of glutaric anhydride $(1.1 \mathrm{~g}, 10 \mathrm{mmol})$ in $5 \mathrm{~mL}$ of THF was added to a solution of benzoic hydrazide $(1.4 \mathrm{~g}, 10 \mathrm{mmol})$ in $50 \mathrm{~mL}$ of chloroform 
drop by drop. The mixture was stirred for $6 \mathrm{~h}$ at r.t. The white precipitate was collected, washed three times with $25-\mathrm{mL}$ portions of chloroform and dried overnight under vacuum. The yield was $0.50 \mathrm{~g}(20 \%) .{ }^{1} \mathrm{H}$ NMR $(300 \mathrm{MHz}$, $\mathrm{d}_{6}$-DMSO): $\delta 11.97(\mathrm{~s}, 1 \mathrm{H}), 10.29(\mathrm{~s}, 1 \mathrm{H}), 9.88(\mathrm{~s}, \mathrm{H}), 7.86(\mathrm{~d}, 2 \mathrm{H}), 7.58(\mathrm{t}, 1 \mathrm{H})$, $7.49(\mathrm{t}, 2 \mathrm{H}), 2.30(\mathrm{t}, 2 \mathrm{H}), 2,23(\mathrm{t}, 2 \mathrm{H}), 1.74(\mathrm{~m}, 2 \mathrm{H}) ;{ }^{13} \mathrm{C}$ NMR $(75 \mathrm{MHz}$ DMSO-d $\left._{6}\right) \delta 174.6,171.6,165.9,132.9,132.2,129.1,127.9,33.3,32.9,20.9$; EI-MS $m / z$ (\% relative intensity): $250\left(0.2, \mathrm{M}^{+}\right), 173(10.9)$; $\mathrm{mp} 164-165^{\circ} \mathrm{C}$.

2-Pyridin-2-yl-1H-phenanthro[9, 10-d] imidazole

A solution of phenanthrene-9,10-dione $(1.0 \mathrm{~g}, 5.0 \mathrm{mmol})$ and pyridine-2-carbaldehyde $(0.65 \mathrm{~g}, 6.0 \mathrm{mmol})$ was stirred at refulx in $30 \mathrm{~mL}$ of glacial acetic acid containing ammonium acetate $(4.6 \mathrm{~g}, 60 \mathrm{mmol})$ for $12 \mathrm{~h}$. The crude product was purified by chromatography on silica gel using $\mathrm{CH}_{2} \mathrm{Cl}_{2} / \mathrm{EtOAc}$ $(10 / 1 \mathrm{v} / \mathrm{v})$ as the eluent. The yield was $0.60 \mathrm{~g}(40 \%) .{ }^{1} \mathrm{H}$ NMR $(300 \mathrm{MHz}$, $\left.\mathrm{d}_{6}-\mathrm{DMSO}\right): \delta 14.11(\mathrm{~s}, 1 \mathrm{H}), 8.86(\mathrm{~m}, 3 \mathrm{H}), 8.79(\mathrm{~d}, 1 \mathrm{H}), 8.63(\mathrm{~d}, 1 \mathrm{H}), 8.46(\mathrm{~d}, 1 \mathrm{H})$, $8.05(\mathrm{t}, 1 \mathrm{H}), 7.73(\mathrm{~m}, 2 \mathrm{H}), 7.65(\mathrm{t}, 2 \mathrm{H}), 7.53(\mathrm{~m}, 1 \mathrm{H}) ;{ }^{13} \mathrm{C}$ NMR $(75 \mathrm{MHz}$, DMSO-d 6 ) $\delta 150.6,149.6,149.2,145.7,138.1,137.9,128.5,128.3,127.8,127.6$, $127.2,126.2,125.9,124.7,124.6,124.5,124.3,123.6,122.7,121.5,121.2 ;$ EI-MS $m / z\left(\%\right.$ relative intensity): $295\left(100, \mathrm{M}^{+}\right) ; \mathrm{mp} 219-220{ }^{\circ} \mathrm{C}$.

\section{2,3-Diaminonaphthalene}

A mixture of 2,3-dihydroxynaphthalene $(8.0 \mathrm{~g}, 50 \mathrm{mmol})$ and $50 \mathrm{~mL}$ of 
aqueous ammonia was kept at $180^{\circ} \mathrm{C}$ for $32 \mathrm{~h}$ in a steel autoclave. The solid was collected by filtration and then dissolved in $400 \mathrm{~mL}$ of hot chloroform. The insoluble solid was filtered off, and then evaporation of solvent from the filtrate afforded the final product. The yield was $4.6 \mathrm{~g}(51 \%) .{ }^{\mathrm{l}} \mathrm{H} \mathrm{NMR}\left(300 \mathrm{MHz}, \mathrm{CDCl}_{3}\right)$ $\delta 7.58(\mathrm{~m}, 2 \mathrm{H}), 7.23(\mathrm{~m}, 2 \mathrm{H}), 7.07(\mathrm{~s}, 2 \mathrm{H}) ;{ }^{13} \mathrm{C} \mathrm{NMR}\left(75 \mathrm{MHz}, \mathrm{CDCl}_{3}\right) \delta 136.2$, 129.7, 125.5, 123.2, 111.1; EI-MS $m / z$ (\% relative intensity): $160\left(100, \mathrm{M}^{+}\right)$.

\section{2,3-Bis (2-pyridyl) benzoquinoxaline (dpb)}

A solution of 2,2'-pyridil (1.09 $\mathrm{g}, 5.12 \mathrm{mmol})$ and 2,3-diaminonaphthalene $(0.56 \mathrm{~g}, 5.20 \mathrm{mmol})$ in $35 \mathrm{~mL}$ of absolute ethanol was stirred at reflux for $5 \mathrm{~h}$. The mixture was allowed to cool to r.t. The solid was collected by filtration as yellow crystals. The crude product was purified by recrystallization twice from absolute ethanol. The yield was $0.70 \mathrm{~g}(48 \%) ;{ }^{1} \mathrm{H}$ NMR $\left(300 \mathrm{MHz}, \mathrm{DMSO}-\mathrm{d}_{6}\right) \delta 7.37(\mathrm{t}$, 2H), $7.70(\mathrm{t}, 4 \mathrm{H}), 7.98(\mathrm{t}, 2 \mathrm{H}), 8.08(\mathrm{~d}, 2 \mathrm{H}), 8.27(\mathrm{t}, 4 \mathrm{H}), 8.90(\mathrm{~d}, 2 \mathrm{H}),{ }^{13} \mathrm{C}$ NMR $\left(75 \mathrm{MHz}, \mathrm{DMSO}-\mathrm{d}_{6}\right) \delta 123.8,124.2,127.7,127.9,128.9,134.3,137.3,137.4$, 148.4, 153.5, 157.5; EI-MS $m / z$ (\% relative intensity): $334\left(\mathrm{M}^{+}, 58.5\right) ; \mathrm{mp}$ $169-170{ }^{\circ} \mathrm{C}$.

\section{Complex Synthesis}

$\mathrm{Ru}(\mathrm{PBIm}-\mathrm{H})_{2} \mathrm{Cl}_{2} \cdot 2 \mathrm{H}_{2} \mathrm{O}$

A solution of $\mathrm{RuCl}_{3} \cdot 3 \mathrm{H}_{2} \mathrm{O}(1.32 \mathrm{~g}, 5.07 \mathrm{mmol})$ and PBIm-H $(2.0 \mathrm{~g}, 10.2$ mmol) in $20 \mathrm{~mL}$ of DMF was stirred at reflux for $12 \mathrm{~h}$. The solvent was then 
reduced. The crude product was precipitated from ether, washed well with several portions of cold water, and dried under vacuum. The final product was isolated as dark brown crystal. The yield was $2.4 \mathrm{~g}(79 \%)$. ESI-MS $m / z$ (\% relative intensity): $599(0.7, \mathrm{M}+\mathrm{H}), 566\left(8.8, \mathrm{M}-\mathrm{Cl}-2 \mathrm{H}_{2} \mathrm{O}+\mathrm{CH}_{3} \mathrm{CN}\right) 562\left(16, \mathrm{M}-2 \mathrm{H}_{2} \mathrm{O}\right), 560$ $\left(33, \mathrm{M}-2 \mathrm{H}-2 \mathrm{H}_{2} \mathrm{O}\right), 545\left(9.5, \mathrm{M}-\mathrm{Cl}-\mathrm{H}_{2} \mathrm{O}\right), 491\left(8, \mathrm{M}-2 \mathrm{H}_{2} \mathrm{O}-2 \mathrm{Cl}\right)$.

$\mathrm{Ru}(\mathrm{acac})_{2}\left(\mathrm{CH}_{3} \mathrm{CN}\right)_{2}$

Tris(acetylacetonato)ruthenium $(0.50 \mathrm{~g}, 1.25 \mathrm{mmol})$ was dissolved in a mixture of $120 \mathrm{~mL}$ of ethanol, $20 \mathrm{~mL}$ of $\mathrm{CH}_{3} \mathrm{CN}$, and $15 \mathrm{~mL}$ of water. After $15 \mathrm{~g}$ of zinc amalgam (containing $12 \mathrm{~g}$ of zinc) was introduced, the mixture was refluxed for $2 \mathrm{~h}$. The colour of the solution gradually turned from red to orange. The solid was filtered, and the filtrate was evaporated to dryness. The final product was recrystallized from $10 \mathrm{~mL}$ of ethanol. The yield was $0.30 \mathrm{~g}(63 \%)$. ESI-MS $m / z$ (\% relative intensity): $382(59, \mathrm{M}+\mathrm{H}), 342\left(1.3, \mathrm{M}-\mathrm{CH}_{3} \mathrm{CN}\right), 302$ $\left(1.2, \mathrm{M}-2 \mathrm{CH}_{3} \mathrm{CN}\right), 533(2.2, \mathrm{M}-\mathrm{Cl}), 497\left(1.48, \mathrm{M}-\mathrm{Cl}-2 \mathrm{H}_{2} \mathrm{O}\right)$.

\section{Complex 3.2}

A solution of $\mathrm{Ru}(\mathrm{bpy})_{2} \mathrm{Cl}_{2} \cdot 2 \mathrm{H}_{2} \mathrm{O}(0.532 \mathrm{~g}, 1.02 \mathrm{mmol})$ and $\mathrm{PBIm}-\mathrm{H}(0.20 \mathrm{~g}$, $1.02 \mathrm{mmol})$ in ethylene glycol $(20 \mathrm{~mL})$ was stirred at reflux for approximately 12 $\mathrm{h}$ under argon atmosphere. After cooling to room temperature, the product was precipitated by addition of excess $\mathrm{NH}_{4} \mathrm{PF}_{6}$ aqueous solution. The resulting red solids were collected by filtration, re-dissolved in acetone, precipitated in water 
and dried under vacuum overnight. The yield was $0.82 \mathrm{~g}(90 \%)$. ESI-MS $m / z(\%$ relative intensity): $755\left(0.2, \mathrm{M}-\mathrm{PF}_{6}\right), 305\left(100, \mathrm{M}-2 \mathrm{PF}_{6}\right)$.

\section{Complex 3.3}

$\mathrm{Ru}(\text { bpy })_{2} \mathrm{Cl}_{2} \cdot 2 \mathrm{H}_{2} \mathrm{O}(0.35 \mathrm{~g}, 0.67 \mathrm{mmol})$, PHPI $(0.20 \mathrm{~g}, 0.67 \mathrm{mmol})$ and ethylene glycol (20ml). Yield: $0.61 \mathrm{~g}(88 \%)$; ESI-MS $\mathrm{m} / \mathrm{z}$ (\% relative intensity): $355\left(100, \mathrm{M}-2 \mathrm{PF}_{6}\right), 708\left(100, \mathrm{M}-2 \mathrm{PF}_{6}\right)$.

\section{Complex 3.4}

$\mathrm{Ru}(\mathrm{PBIm}-\mathrm{H})_{2} \mathrm{Cl}_{2} \cdot 2 \mathrm{H}_{2} \mathrm{O}(0.40 \mathrm{~g}, 0.68 \mathrm{mmol})$, PHPI $(0.20 \mathrm{~g}, 0.68 \mathrm{mmol})$ and ethylene glycol $(20 \mathrm{~mL})$. Yield: $0.44 \mathrm{~g}(60 \%)$. ESI-MS $\mathrm{m} / \mathrm{z}$ (\% relative intensity): $394\left(100, \mathrm{M}-2 \mathrm{PF}_{6}\right), 297\left(23, \mathrm{M}-\mathrm{PBIm}-\mathrm{PF}_{6}\right), 196(25, \mathrm{M}-2 \mathrm{PBIm}$ $\left.-2 \mathrm{PF}_{6}\right)$

\section{Complex 3.5}

$\mathrm{Ru}(\mathrm{PBIm}-\mathrm{H})_{2} \mathrm{Cl}_{2} \cdot 2 \mathrm{H}_{2} \mathrm{O}(0.30 \mathrm{~g}, 0.50 \mathrm{mmol})$, acetylacetone $(0.20 \mathrm{~g}, 1.02$ mmol) and 1:1 $\mathrm{H}_{2} \mathrm{O} / \mathrm{EtOH}(60 \mathrm{~mL})$. Yield: $0.82 \mathrm{~g}(90 \%)$. ESI-MS $\mathrm{m} / \mathrm{z}(\%$ relative intensity): $594\left(6, \mathrm{M}-\mathrm{PF}_{6}\right), 592\left(29, \mathrm{M}-\mathrm{PF}_{6}\right), 591\left(48, \mathrm{M}-2 \mathrm{PF}_{6}\right)$.

\section{Complex 3.6}

$\mathrm{Ru}(\mathrm{bpy})_{2} \mathrm{Cl}_{2} \cdot 2 \mathrm{H}_{2} \mathrm{O}(0.30 \mathrm{~g}, 0.60 \mathrm{mmol})$, dpb $(0.20 \mathrm{~g}, 0.6 \mathrm{mmol})$ and ethylene glycol $(20 \mathrm{~mL})$. Yield: $0.40 \mathrm{~g}(63 \%)$. ESI-MS $\mathrm{m} / \mathrm{z}$ (\% relative intensity): 
$893\left(4, \mathrm{M}-\mathrm{PF}_{6}\right), 374\left(100, \mathrm{M}-2 \mathrm{PF}_{6}\right)$.

\section{Complex 3.7}

$\mathrm{Ru}(\mathrm{PBIm}-\mathrm{H})_{2} \mathrm{Cl}_{2} \cdot 2 \mathrm{H}_{2} \mathrm{O}(0.36 \mathrm{~g}, 0.60 \mathrm{mmol}), \mathrm{dpb}(0.20 \mathrm{~g}, 0.60 \mathrm{mmol})$ and ethylene glycol $(20 \mathrm{~mL})$. Yield: $0.34 \mathrm{~g}(50 \%)$. ESI-MS $\mathrm{m} / \mathrm{z}$ (\% relative intensity): $413\left(92, \mathrm{M}-2 \mathrm{PF}_{6}\right), 971\left(0.2, \mathrm{M}-\mathrm{PF}_{6}\right)$.

\section{Complex 3.8}

$\mathrm{Ru}(\mathrm{acac})_{2}\left(\mathrm{CH}_{3} \mathrm{CN}\right)_{2}(0.17 \mathrm{~g}, 0.45 \mathrm{mmol}), \mathrm{dpb}(0.15 \mathrm{~g}, 0.45 \mathrm{mmol})$ and ethanol $(50 \mathrm{~mL})$. Yield: $0.10 \mathrm{~g}(31 \%)$. ESI-MS $m / z$ (\% relative intensity): 634 (3.3, $\mathrm{M}+\mathrm{H})$.

\section{Complex 3.9}

$\mathrm{Ru}(\mathrm{bpy})_{2} \mathrm{Cl}_{2} \cdot 2 \mathrm{H}_{2} \mathrm{O}(1.8 \mathrm{~g}, 3.5 \mathrm{mmol})$, dibenzoylhydrazide $(0.40 \mathrm{~g}, 1.7$ mmol), $\mathrm{NaOH}(0.3 \mathrm{~g}, 7.5 \mathrm{mmol})$ and $80 \mathrm{~mL}$ of 5:1 $\mathrm{H}_{2} \mathrm{O} / \mathrm{EtOH}$. Yield: $2.6 \mathrm{~g}(80 \%)$. ESI-MS $m / z$ (\% relative intensity): $1207\left(11.4, \mathrm{M}-\mathrm{PF}_{6}\right), 531\left(100, \mathrm{M}-2 \mathrm{PF}_{6}\right)$.

\section{Complex 3.10}

$\mathrm{Ru}(\mathrm{PBIm}-\mathrm{H})_{2} \mathrm{Cl}_{2} \cdot 2 \mathrm{H}_{2} \mathrm{O}(0.37 \mathrm{~g}, 0.62 \mathrm{mmol}), \mathrm{dpb}(0.10 \mathrm{~g}, 0.30 \mathrm{mmol})$ and ethylene glycol $(20 \mathrm{~mL})$. Yield: $0.39 \mathrm{~g}(62 \%)$; ESI-MS $\mathrm{m} / z$ (\% relative intensity): $825\left(60, \mathrm{M}+\mathrm{CH}_{3} \mathrm{CN}-2 \mathrm{PF}_{6}\right)$. 
Complex 3.11

$\mathrm{Ru}(\mathrm{bpy})_{2} \mathrm{Cl}_{2} \cdot 2 \mathrm{H}_{2} \mathrm{O}(0.65 \mathrm{~g}, 1.2 \mathrm{mmol})$, dpb $(0.20 \mathrm{~g}, 0.6 \mathrm{mmol})$ and ethanol/water $(20 \mathrm{~mL} / 10 \mathrm{~mL})$. Yield: $0.93 \mathrm{~g}(90 \%)$. ESI-MS $\mathrm{m} / \mathrm{z}(\%$ relative intensity): $893\left(0.9, \mathrm{M}-\mathrm{Ru}(\mathrm{bpy})_{2}-3 \mathrm{PF}_{6}\right), 726\left(0.87, \mathrm{M}-2 \mathrm{PF}_{6}\right), 374(40, \mathrm{M}-$ $\left.\mathrm{Ru}(\mathrm{bpy})_{2}-4 \mathrm{PF}_{6}\right)$

Complex 3.12

$\mathrm{Ru}(\mathrm{acac})_{2}\left(\mathrm{CH}_{3} \mathrm{CN}\right)_{2}(0.25 \mathrm{~g}, 0.65 \mathrm{mmol}), \mathrm{dpb}(0.10 \mathrm{~g}, 0.30 \mathrm{mmol})$ and ethanol $(50 \mathrm{~mL})$. Yield: $0.15 \mathrm{~g}(53 \%)$. ESI-MS $m / z$ (\% relative intensity): 934 $(0.73, \mathrm{M}+\mathrm{H}), 634(1.13, \mathrm{M}-2 \mathrm{acac})$.

Complex $\boldsymbol{A}$

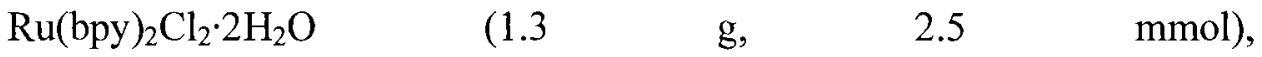
1-benzoyl-2-(4-carboxybutyryl)-hydrazine $(0.30 \mathrm{~g}, 1.3 \mathrm{mmol})$, and $\mathrm{NaOH}(0.20 \mathrm{~g}$, $5.0 \mathrm{mmol})$. Yield: $1.8 \mathrm{~g}(74.3 \%)$. ESI-MS $\mathrm{m} / z$ (\% relative intensity): 1220 (3, M $\left.\mathrm{PF}_{6}\right), 537\left(100, \mathrm{M}-2 \mathrm{PF}_{6}\right)$.

\section{Complex 3.13}

A solution of the complex A (1.68 $\mathrm{g}, 1.30 \mathrm{mmol})$, 4-(dimethylamino) pyridine (DMAP) $(0.07 \mathrm{~g}, 0.60 \mathrm{mmol})$ and 1,1'-bi-2-naphthol $(0.18 \mathrm{~g}, 0.60 \mathrm{mmol})$ in $20 \mathrm{~mL}$ of dry $\mathrm{CH}_{3} \mathrm{CN}$ was cooled in an ice bath. 1-Ethyl-3-[3-(dimethylamino)propyl] carbodiimide hydrochloride (EDCI) (0.26 g, 
$1.38 \mathrm{mmol}$ ) was added. The reaction mixture was stirred at $0{ }^{\circ} \mathrm{C}$ for $2 \mathrm{~h}$ and at room temperature overnight. The solution was concentrated to dryness, and the crude product was purified by chromatography on neutral alumina using toluene/ $\mathrm{CH}_{3} \mathrm{CN}$ as eluent. The shine dark purple product was obtained in $72 \%$ yield . ESI-MS $m / z$ (\% relative intensity): $600\left(100, \mathrm{M}-4 \mathrm{PF}_{6}\right), 848(4.1, \mathrm{M}-$ 3PF6), $1345\left(0.4, \mathrm{M}-2 \mathrm{PF}_{6}\right)$. 


\section{References}

1. (a) N. E. Tokel, A. J. Bard, J. Am. Chem. Soc. 1972, 94, 2862. (b) M. Buda, G. Kalyuzhny, A. J. Brad, J. Am. Chem. Soc. 2002, 124, 6090. (c) H. Rudmann, S. Shimada, M. F. Rubner, J. Am. Chem. Soc. 2002, 124, 4918. (d) Y. Chuai, D. N. Lee, C. Zhen, J. H. Min, B. H. Kim, D. Zou, Synth. Met. 2004, 145, 259. (e) H. J. Bolink, L. Cappelli, E. Coronado, M. Grätzel, M. K. Nazeeruddin, J. Am. Chem. Soc. 2006, 128, 46. (f) J. D. Slinker, J. Rivnay, J. S. Moskowitz, J. B. Parker, S. Bernhard, H. D. Abruña, G. G. Malliaras, J. Mater. Chem. 2007, 17, 2976. (g) J. Slinker, D. Bernards, P. L. Houston, H. D. Abruna, S. Bernhard, G. G. Maliaras, Chem. Commun. 2003, 2392. (h) E. S. Handy, A. J. Pal, M. F. Rubner, J. Am. Chem. Soc., 1999, 121, 3525. (i) F. G. Gao, A. J. Bard, J. Am.Chem. Soc. 2000, 122, 7426. (j) F. R. F. Fan, A. J. Bard, J. Phys. Chem. B, 2003, 107, 1781. (k) H. Rudmann, M. F. Rubner, J. Appl. Phys. 2001, 90, 4338. (I) K. M. Maness, R. H. Terrill, T. J. Meyer, R. W. Murry, R. M. Wightman, J. Am. Chem. Soc. 1997, 118, 10609. (m) K. M. Maness, H. Masui, R. M. Wightman, R. W. Murry, J. Am. Chem. Soc. 1997, 119, 3987. (n) C. M. Elliott, F. Pichot, C. J. Bloom, L. S. Rider, J. Am. Chem. Soc. 1998, 120, 6781. (o) C. H. Lyons, E. D. Abbas, J. K. Lee, and M. F. Rubner, J. Am. Chem. Soc. 1998, 120, 12100. (p) C. Y. Liu, A. J. Bard, J. Am. Chem. Soc. 2002, 124, 4190.

(q) S. Bernhard, J. A. Barron, P. L. Houston, H. D. Abruna, J. L. Ruglovsky, X. Gao, G. G. Malliara, J. Am. Chem. Soc. 2002, 124, 13624. 
(r) G. Kalyuzhny, M. Buda, J. McNeill, P. Barbara, and A. J. Bard, J. Am. Chem. Soc. 2003, 125, 6272. (s) H. Rudmann, S. Shimada, M. F. Rubner, J. Appl. Phys. 2003, 94, 115.

2. K. Z. Wang, L. H. Gao, G. Y. Bai, L. P. Jin. Inorg. Chem. Commun. 2002, 5, 841.

3. J. A. Baiano, D. L. Carlson, G. M. Wolosh, D. E. DeJesus, C. F. Knowles, E. G. Szabo, W. R. Murphy, Inorg. Chem. 1990, 29, 2327.

4. T. Kobayashi, Y. Nishina, K. Shimizu, G.P. Sato. Chem. Lett. 1988, 1137.

5. B. P. Sullivan, D. J. Salmon, T. J. Meyer, Inorg. Chem. 1978, 17, 3334.

6. V. Kasack, W. Kaim, H.Binder, J. Jordanov, E. Roth, Inorg. Chem. 1995, $34,1924$.

7. M. K. Dhaon, R. K. Olsen, K. Ramassamy, J. Org. Chem. 1982, 47, 1962.

8. G. N. A. Nallas, K. J. Brewer, Inorg. Chim. Acta. 1997, 257, 27.

9. S. F. McClanahan, R. F. Dallinger, F. J. Holler, J. R. Kincaid, J. Am. Chem. Soc. $1985,107,4853$.

10. M. Haga, T. Matsumura-Inoue, K. Shimizu, G. P. Satô, J. Chem. Soc. Dalton Trnas. 1989, 371.

11. E. M. Kober, J. V. Caspar, R. S. Lumpkin, T. J. Meyer, J. Phys. Chem. 1986, 90,3722 .

12. S. Wang, X. Li, S. Xun, X. Wan, Z. Y. Wang, Macromolecules 2006, 39, 7502. 
Chapter 4 Synthesis and Characterizations of

\section{2,3-Bis(2-pyridyl)benzoquinoxaline-Containing Polymers and}

\section{Complexation with Ruthenium and Other Metals}

\subsection{Introduction}

The bi-, tri- and polypyridyl compounds and polymers have received much attention due to their ability of complexation with transition metals. ${ }^{1}$ A variety of metal ions can be chelated by the bipyridyl units in polymer backbone, giving rise to the metal ion chromic effects in absorption and emission. The conjugated polymers containing polypyridyl units could be candidates for chemosensors. In comparison with the conventional molecular-based fluorescent chemosensors, conjugated polymer chemosensors show enhanced sensitivity through the sensory signal amplification. ${ }^{2}$ Swager et al. demonstrated that the receptors that are interconnected as a molecular wire can have the energy migration occurring along the polymer backbone upon excitation. ${ }^{2 a}$ Consequently, the polymer receptor produces a response larger than an analogous small mono-receptor system. ${ }^{2 b}$

Among pyridyl derivatives, 2,3-bis(2-pyridyl)benzoquinoxaline (dpb) (Figure 4.1) has a low-energy $\pi^{*}$ orbital and is an important ligand for metal complexation. ${ }^{3}$ In this chapter, a series of luminescent $\pi$-conjugated polymers containing dpb unit are designed and their photophysical properties responsive to the acid and various metal ions are studied. It is well known that, for bipyridyl-containing polymers, the conformational changes in the backbone play the most important role in producing the observed chromic effects. ${ }^{4}$ Therefore, the 
different sensitivity and selectivity of the conjugated polymer-based chemosensors can be achieved by tuning the conjugation length and as well as the rigidity of the polymer backbones.<smiles>c1ccc(-c2nc3cc4ccccc4cc3nc2-c2ccccn2)nc1</smiles>

Figure 4.1. Structure of dpb.

\subsection{Synthesis and characterization}

The synthetic routes to the monomers and polymers are illustrated in Scheme 4.1. 1,4-Dibromo-2,3-diaminonaphthalene (4.1) was synthesized using the reported method. ${ }^{5}$ 5,10-Dibromo-2,3-bis(2-pyridyl)benzoquinoxaline (4.2) was prepared from 4.1 and 2,2'-pyridil in ethanol with a yield of $82 \%$.

The homopolymer PDPB (Scheme 4.1) was prepared using bis(1,5-cyclooctadiene)nickel $(0)\left(\mathrm{Ni}(\mathrm{COD})_{2}\right)$ as a catalyst,${ }^{6}$ in anhydrous DMF at reflux for $26 \mathrm{~h}$ with a yield of $71 \%$. PFO-DPB was prepared in $76 \%$ yield via the palladium-catalyzed Suzuki coupling between $\mathbf{4 . 2}$ and 9,9-dioctylfluorene-2,7-bis(trimethyleneborate) in a mixture of THF and aqueous $\mathrm{Na}_{2} \mathrm{CO}_{3}$ containing $5 \mathrm{~mol} \% \mathrm{Pd}\left(\mathrm{PPh}_{3}\right)_{4}$ as the catalyst. 


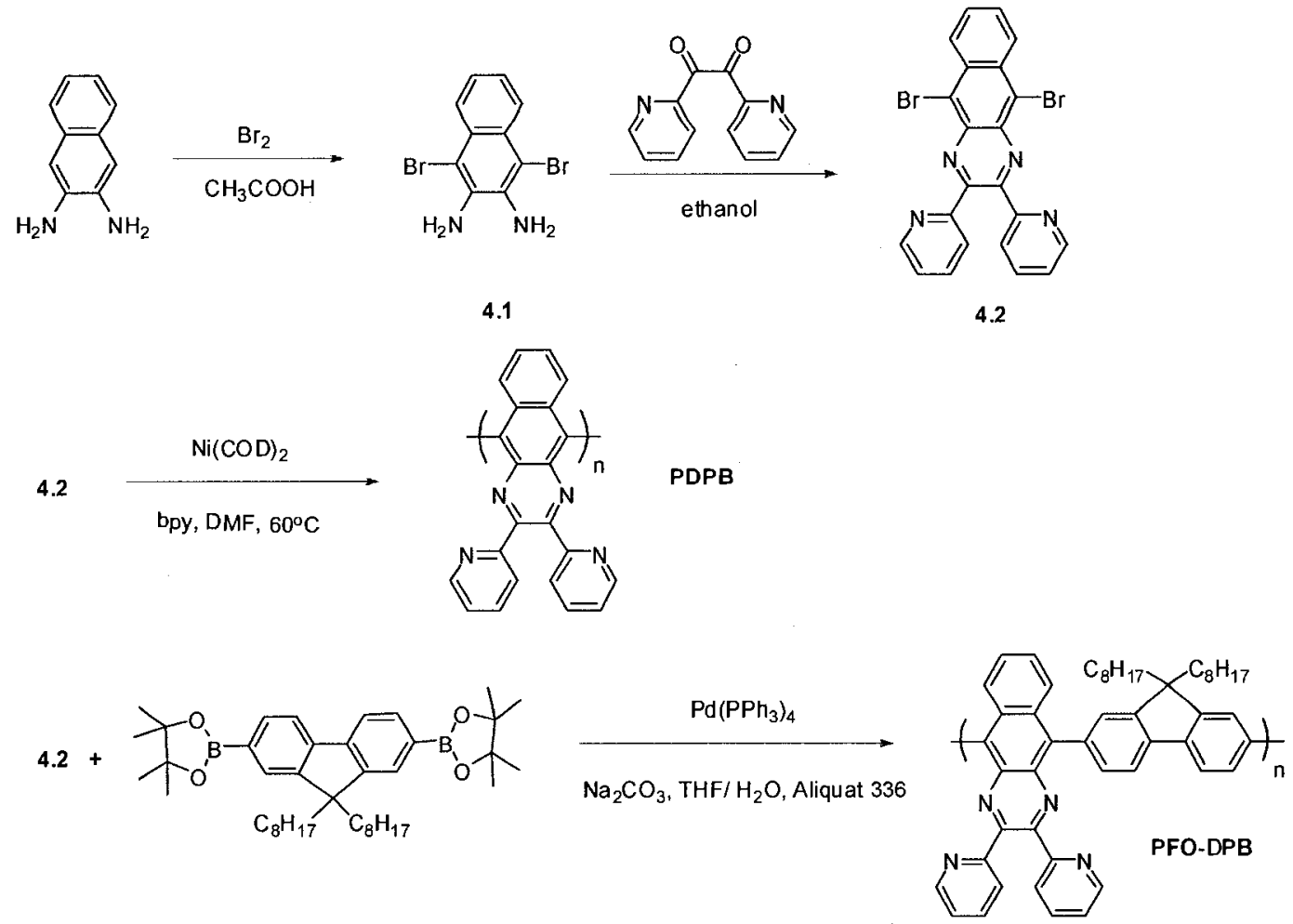

Scheme 4.1. Synthetic routes to the monomer 4.2 and polymers.

Characterizations of the polymers are summarized in Table 4.1. PDPB and PFO-DPB are green and yellow fibrous solids, respectively. The resulting PFO-DPB readily dissolves in common organic solvents, such as THF, dichloroethane and chloroform. PDPB has a poor solubility and only dissolves in DMF and DMSO, due to its rigid backbone. The number-average molecular weights $\left(M_{\mathrm{n}}\right)$ of these two polymers are estimated to be 3500 and 10048 (polystyrene standards) with the polydispersity index $\left(M_{\mathrm{w}} / M_{\mathrm{n}}\right)$ of 1.54 and 1.72 , respectively by GPC measurement.

The chemical structures of the polymers were verified by ${ }^{1} \mathrm{H} N M R,{ }^{13} \mathrm{C}$ NMR and FT-IR. Figure 4.2 displays the ${ }^{1} \mathrm{H}$ NMR spectra of PDPB and PFO-DPB. The ${ }^{1} \mathrm{H}$ NMR spectrum of PDPB shows three broad peaks in the 
aromatic region at $\delta 8.03,7.64$ and $7.06 \mathrm{ppm}$, which can be assigned to the protons of dpb. For PFO-DPB, the three peaks at the lower field, $\delta 8.13,7.74$ and $7.18 \mathrm{ppm}$, are from the protons of $\mathrm{dpb}$ and fluorene rings. The peaks of the alkyl side chains of fluorene are observed at $\delta 2.14,1.18$ and 0.83 ppm. FT-IR studies reveal the polymers' characteristic aromatic rings at $1468-1587 \mathrm{~cm}^{-1}$. For PFO-DPB, C-H stretch of the $\mathrm{CH}_{2}$ and $\mathrm{CH}_{3}$ groups are at 2926, 1465 and 1384 $\mathrm{cm}^{-1}$, respectively.

Thermal stability of the polymers was evaluated by thermogravimetric analysis (TGA) in a nitrogen atmosphere. The onset temperature $\left(T_{\mathrm{d}}\right)$ for $5 \%$ weight loss for PFO-DPB was observed at $430{ }^{\circ} \mathrm{C}$, indicating a good thermal stability. However, the $T_{\mathrm{d}}$ of PDPB was only at $280^{\circ} \mathrm{C}$, which might be due to its low molecular weight.

Table 4.1. Characterization of ligand polymers.

\begin{tabular}{ccccccc}
\hline polymer & Yield, $\%$ & color & $M_{\mathrm{n}}{ }^{a}$ & $M_{\mathrm{w}}$ & $M_{\mathrm{w}} / M_{\mathrm{n}}$ & $T_{\mathrm{d}},{ }^{b 0} \mathrm{C}$ \\
\hline DPB & 71 & green & 3500 & 6020 & 1.72 & 280 \\
PFO-DPB & 76 & yellow & 10048 & 15537 & 1.54 & 430 \\
\hline
\end{tabular}

${ }^{a}$ Estimated from GPC (eluent: DMF for PDPB, THF for PFO-DPB, polystyrene standards). ${ }^{b} 5 \%$ weight-loss temperature measured by TGA under $\mathrm{N}_{2}$ with a heating rate of $20^{\circ} \mathrm{C} \mathrm{min}^{-1}$. 


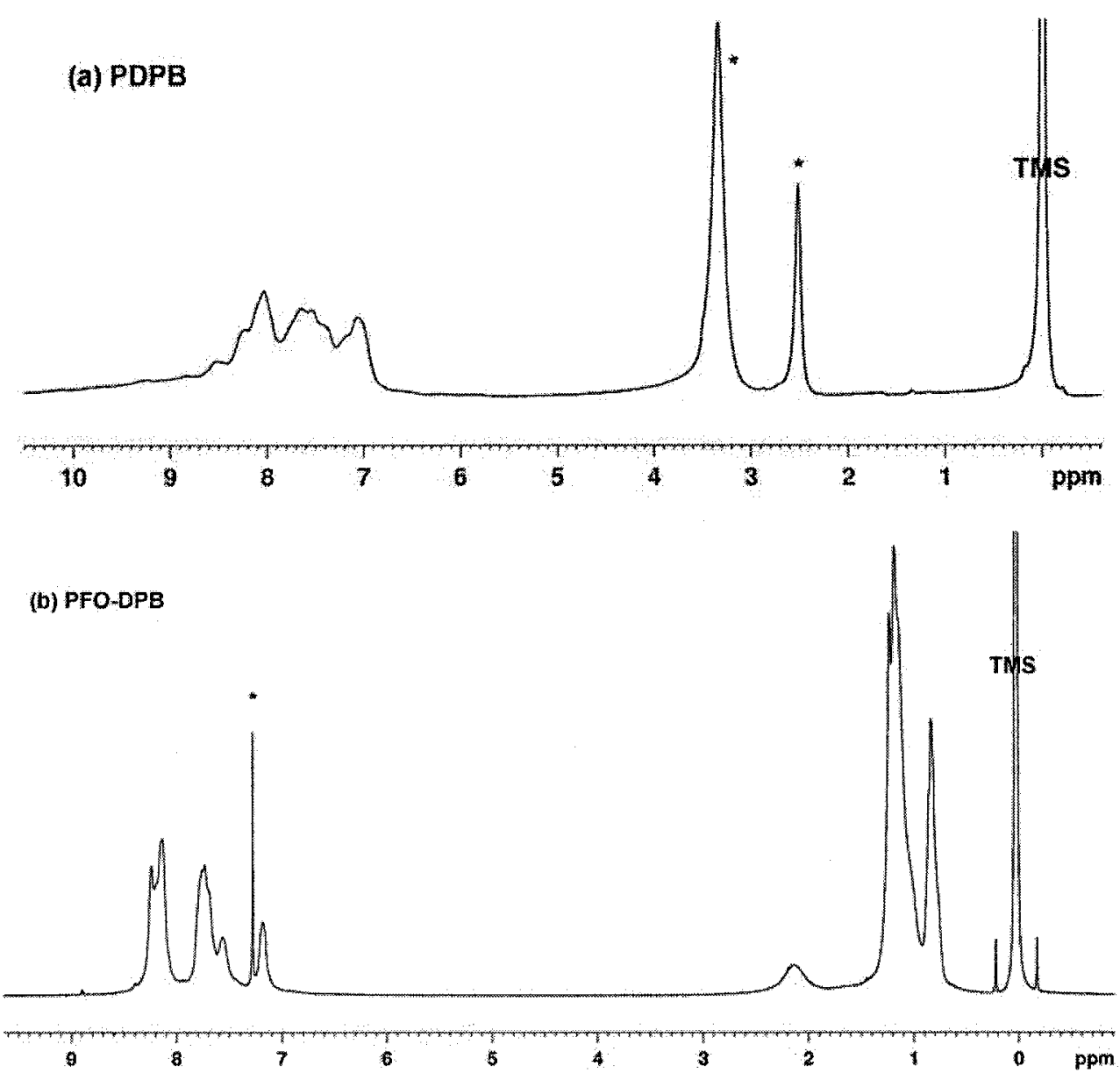

Figure 4.2. ${ }^{1} \mathrm{H}$ NMR spectra of (a) PDPB in $\mathrm{d}_{6}-\mathrm{DMSO}$ and (b) PFO-DPB in $\mathrm{CDCl}_{3}$. The peaks with the ${ }^{*}$ are due to solvent impurities.

\subsection{Absorption and photoluminescent properties of dpb ligand polymers}

The UV-vis absorption and PL spectra of PDPB, PFO-DPB and model compound $\mathrm{dpb}\left(10^{-5} \mathrm{M}\right)$ are shown in Figure 4.3. PDPB exhibits the absorption maximum at $455 \mathrm{~nm}$ attributed to $\pi \rightarrow \pi^{*}$ transition and the PL maximum at 540 nm. In comparison, the absorption and PL spectra of PFO-DPB show a red shift by 11 and $15 \mathrm{~nm}$, respectively. This bathochromic shift could be understood in terms of the better conjugation along PFO-DPB main chain, compared with PDPB. The UV-vis and PL spectra of PDPB and PFO-DPB are obviously red shifted as compared to those of $\mathrm{dpb}\left(\lambda_{\max , \text { abs }}=386 \mathrm{~nm}, \lambda_{\max , \mathrm{PL}}=495 \mathrm{~nm}\right)$, 
indicating the extended $\pi$-conjugation along the polymer backbone.

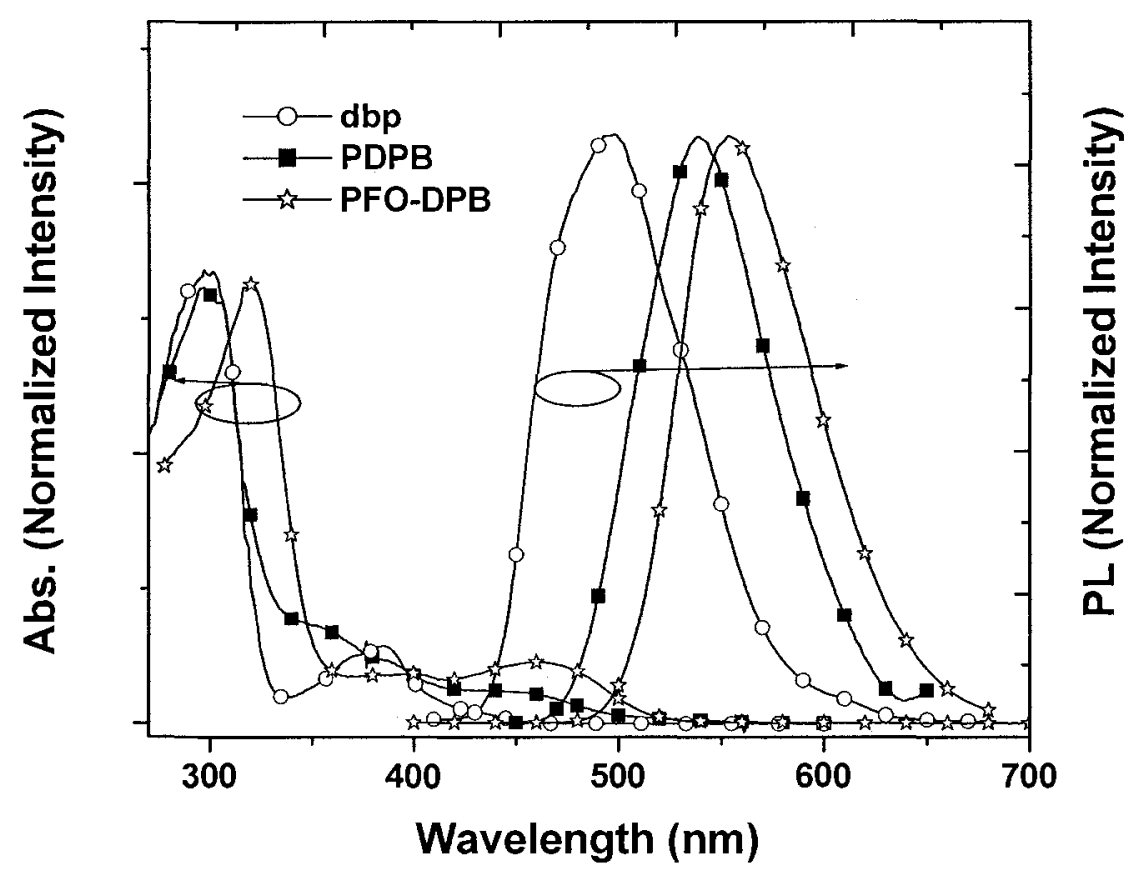

Figure 4.3. Absorption and PL spectra of dpb in THF, PDPB in DMF and PFO-DPB in THF $\left(10^{-5} \mathrm{M}\right)$.

Transparent and uniform films of PDPB and PFO-DPB were prepared on quartz plates by spin-coating their solutions in THF and DMF at room temperature, respectively. As shown in Table 4.2, the emission spectra of the polymer films are red shifted to some extent. For PFO-DPB, the emission peak in the solid state shifted by $15 \mathrm{~nm}$ as compared to its emission in solution at $555 \mathrm{~nm}$. The emission peak of the PDPB film was red shifted about $10 \mathrm{~nm}$ with respect to its spectrum in solution. 
Table 4.2. Absorption and photoluminescent data of $\mathrm{dpb}$ and polymers.

\begin{tabular}{ccccc}
\hline & $\lambda_{\max }(\text { solution })^{\alpha}(\mathrm{nm})$ & \multicolumn{2}{c}{$\lambda_{\max }(\text { film })^{b}(\mathrm{~nm})$} \\
\cline { 2 - 5 } & $\mathrm{abs}$ & $\mathrm{em}$ & $\mathrm{abs}$ & $\mathrm{Em}$ \\
\hline $\mathrm{dpb}$ & 386 & 495 & & \\
PDPB & 455 & 540 & 460 & 550 \\
PFO-DPB & 460 & 555 & 460 & 570 \\
\hline
\end{tabular}

${ }^{a} 10^{-5} \mathrm{M} .^{b}$ thickness: $0.45 \mu \mathrm{m}$.

The polymers are expected to react with protic acids due to the facile protonation of the nitrogen of dpb units. As shown in Figure 4.4, the absorption and PL spectra of PFO-DPB are significantly influenced by protonation. When trichloroacetic acid (TCA) (up to $4.8 \times 10^{-2} \mathrm{M}$ ) was added to a solution of PFO-DPB $\left(4.2 \times 10^{-5} \mathrm{M}\right.$ based on repeating unit) in THF, the absorption peak shifted from $457 \mathrm{~nm}$ to $527 \mathrm{~nm}$. Similar changes were also observed in the PL spectra of PFO-DPB. Upon addition of TCA, the emission spectra are red-shifted by $90 \mathrm{~nm}$, from yellow emission $(555 \mathrm{~nm})$ to red emission $(660 \mathrm{~nm})$, and the maximum peak intensity decreases greatly as a result of the protonation of the $\mathrm{dpb}$ units. The absorption and PL spectra of PDPB also exhibit a similar change upon addition of TCA (Figure 4.5). The spectral red shifts also suggest the presence of intramolecular charge transfer (ICT) between the fluorene units as electron donors and the dpb moieties as acceptors. Protonation of the dpb moieties makes them 
stronger acceptors, thereby enhancing the ICT, which accounts for the observed spectral red shifts. ${ }^{7}$
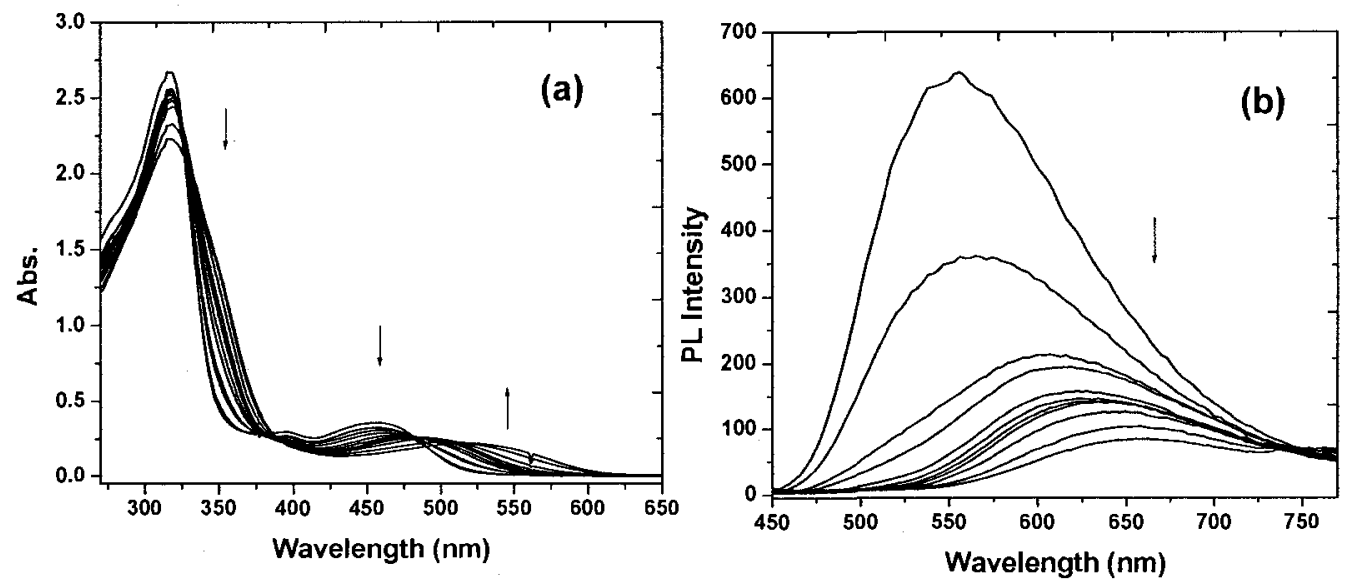

Figure 4.4. Changes in (a) UV-vis absorption and (b) PL spectra of PFO-DPB $\left(4.2 \times 10^{-5} \mathrm{M}\right.$ (repeating unit)) in THF at various concentrations of trichloroacetic acid $(\mathrm{TCA}):[\mathrm{TCA}]=0,5.5 \times 10^{-5}, 3.6 \times 10^{-4}, 5.8 \times 10^{-4}, 1.1 \times 10^{-3}, 1.8 \times 10^{-3}, 3.2$ $\times 10^{-3}, 6.7 \times 10^{-3}, 1.5 \times 10^{-2}, 3.2 \times 10^{-2}, 4.8 \times 10^{-2} \mathrm{M}$. Arrows indicate the direction of the change from low to high concentration.
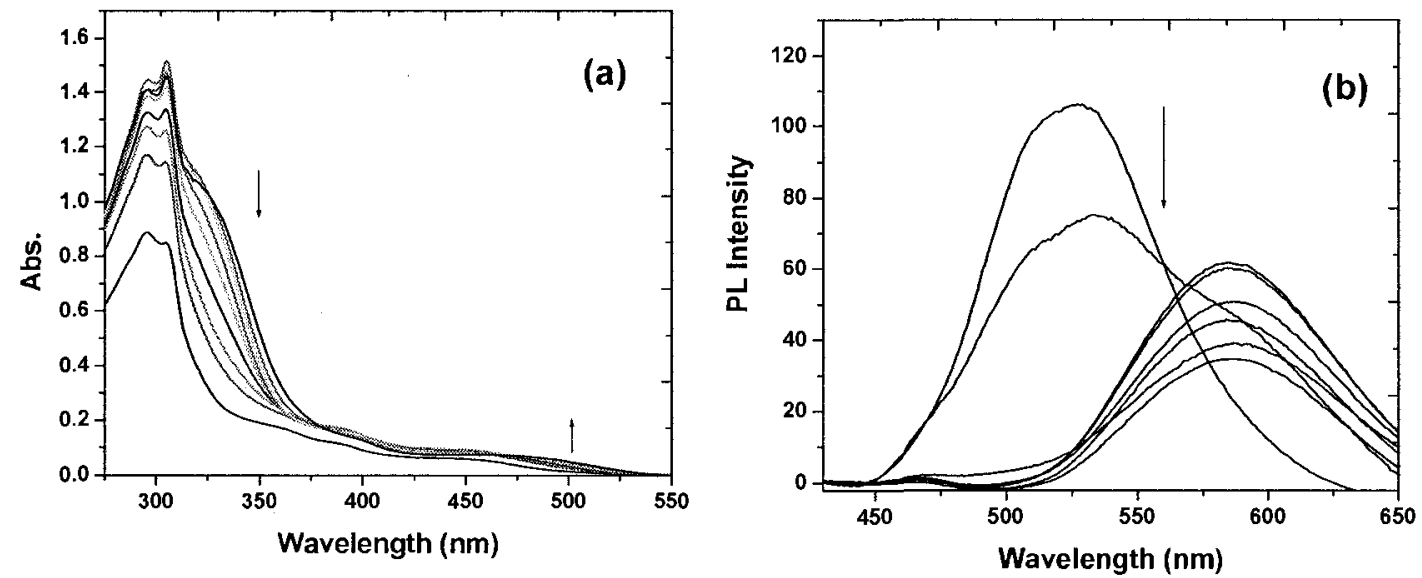

Figure 4.5. Changes in (a) UV-vis absorption and (b) PL spectra of PDPB (6.3 $\times 10^{-5} \mathrm{M}$ (repeating unit)) in $\mathrm{CH}_{3} \mathrm{CN}$ at various concentrations of trichloroacetic acid $(\mathrm{TCA}):[\mathrm{TCA}]=0,1.4 \times 10^{-4}, 3.2 \times 10^{-4}, 9.3 \times 10^{-4}, 2.0 \times 10^{-3}, 3.9 \times 10^{-3}, 9.2$ $\times 10^{-3}, 2.5 \times 10^{-2}, 5.8 \times 10^{-2} \mathrm{M}$. Arrows indicate the direction of the change from low to high concentration. 


\subsection{Absorption and photoluminescent properties of ligand polymers complexed with ruthenium}

Rather than $\mathrm{Ru}(\mathrm{bpy})_{2} \mathrm{Cl}_{2}, \mathrm{Ru}(\mathrm{acac})_{2}\left(\mathrm{CH}_{3} \mathrm{CN}\right)_{2}$ was chosen to coordinate with PFO-DPB to overcome the steric hindrance during complexation. The ruthenium-containing polymer PFO-DPB-Ru was readily synthesized by ligand exchange with a known ruthenium complex (Scheme 4.2). The ruthenium content in the complex polymers was determined by ICP analysis (Table 4.3) and did not reach the theoretical values for complete complexation due to steric hindrance of the polymer backbone. The complex polymers, PFO-DPB-Ru1-3, have the ruthenium content of $3.24 \%, 7.58 \%$ and $11.4 \%$, respectively. The solubility of these complex polymers decreases with the increase of the ruthenium content.
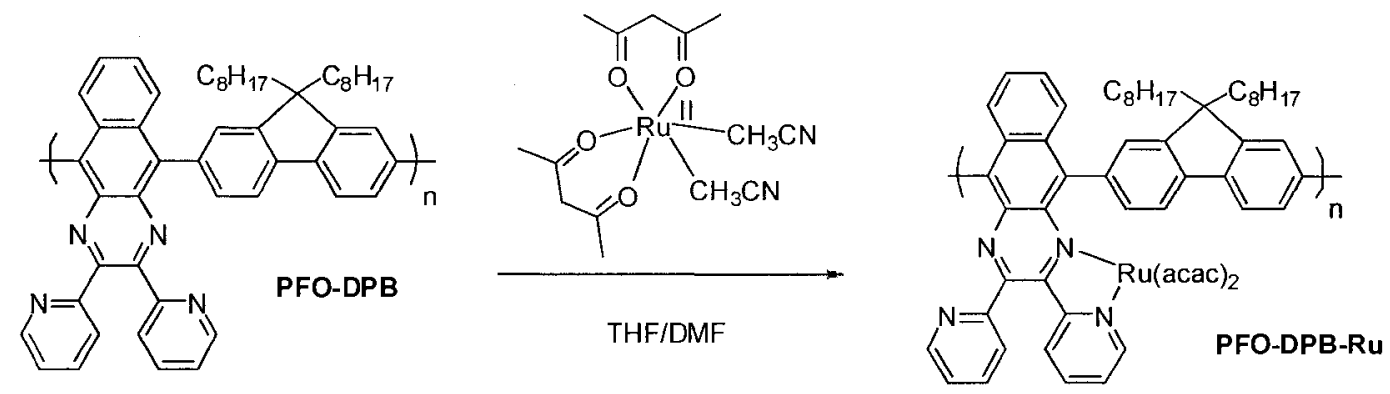

Scheme 4.2. Synthetic routes to the ruthenium complex polymer PFO-DPB-Ru. 
Table 4.3. Ruthenium content in PFO-DPB-Ru.

\begin{tabular}{cccc}
\hline & feed ratio & \multicolumn{2}{c}{ ruthenium content $(\%)$} \\
& PFO-DPB: $\mathrm{Ru}(\mathrm{acac})_{2}\left(\mathrm{CH}_{3} \mathrm{CN}\right)_{2}$ & calculated & obtained \\
\hline PFO-DPB-Ru1 & $1: 0.5$ & 3.44 & 3.24 \\
PFO-DPB-Ru2 & $1: 1$ & 9.47 & 7.58 \\
PFO-DPB-Ru3 & $1: 2.2$ & 14.7 & 11.4 \\
\hline
\end{tabular}

The UV-vis absorption spectra of PFO-DPB-Ru1-3 in solution are shown in Figure 4.6. For all the complex polymers, two absorption bands at 317 and 455 $\mathrm{nm}$ are observed and assigned to the PFO-DPB, and the peak positions are insensitive to the ruthenium content. The broad absorption above $600 \mathrm{~nm}$ increases with the increase of the ruthenium content and thus comes from the ruthenium complex units.

The PL spectra of PFO-DPB and PFO-DPB-Ru1 in chloroform $(5.0 \times$ $\left.10^{-5} \mathrm{M}\right)$ are shown in Figure 4.7. Complete quenching of the emission $\left(\lambda_{\max }=555\right.$ $\mathrm{nm}$ ) arising from the parent polymer is observed, along with appearance of a new PL emission at $635 \mathrm{~nm}$ (excited at $460 \mathrm{~nm}$ ). This result suggests the presence of an energy-transfer process between the main chain and the ruthenium complexes. ${ }^{8}$ The yellow and red emissions are observed for PFO-DPB and PFO-DPB-Ru1, respectively. The full width at half-maximum (FWHM) PL increases from $75 \mathrm{~nm}$ for PFO-DPB to $160 \mathrm{~nm}$ for PFO-DPB-Ru1. It is difficult to obtain the PL spectra for PFO-DPB-Ru2-3 due to their low solubility. 


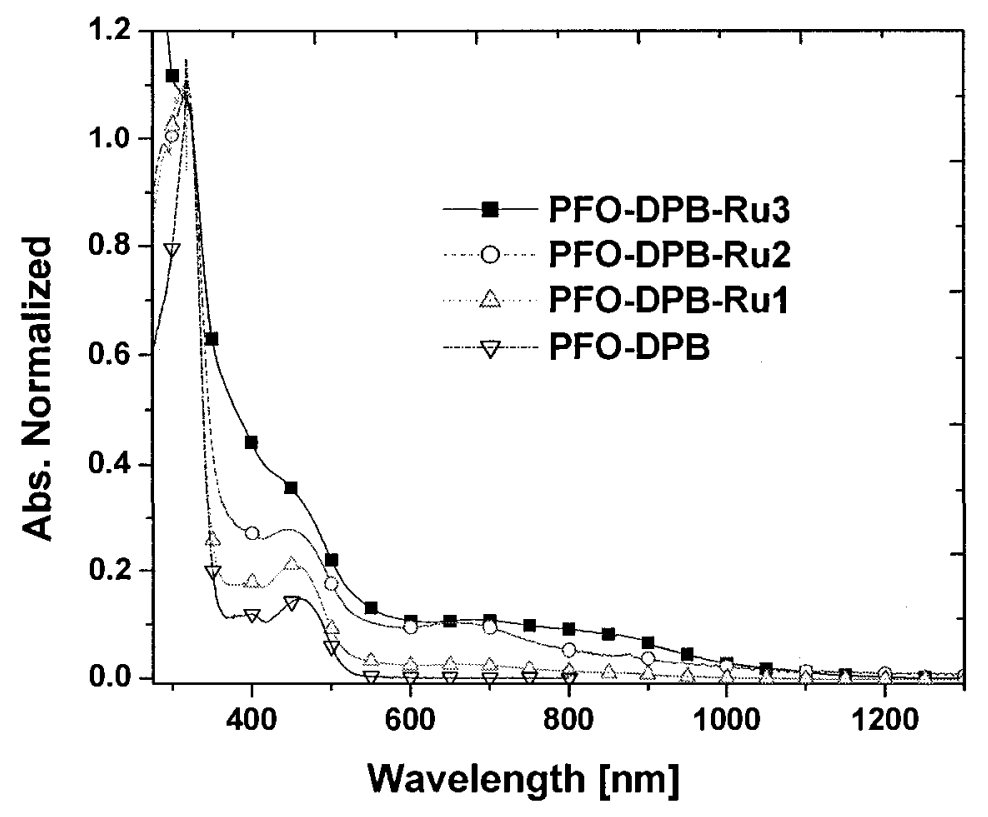

Figure 4.6. Absorption spectra of PFO-DPB and PFO-DPB-Ru1-3 in solution.

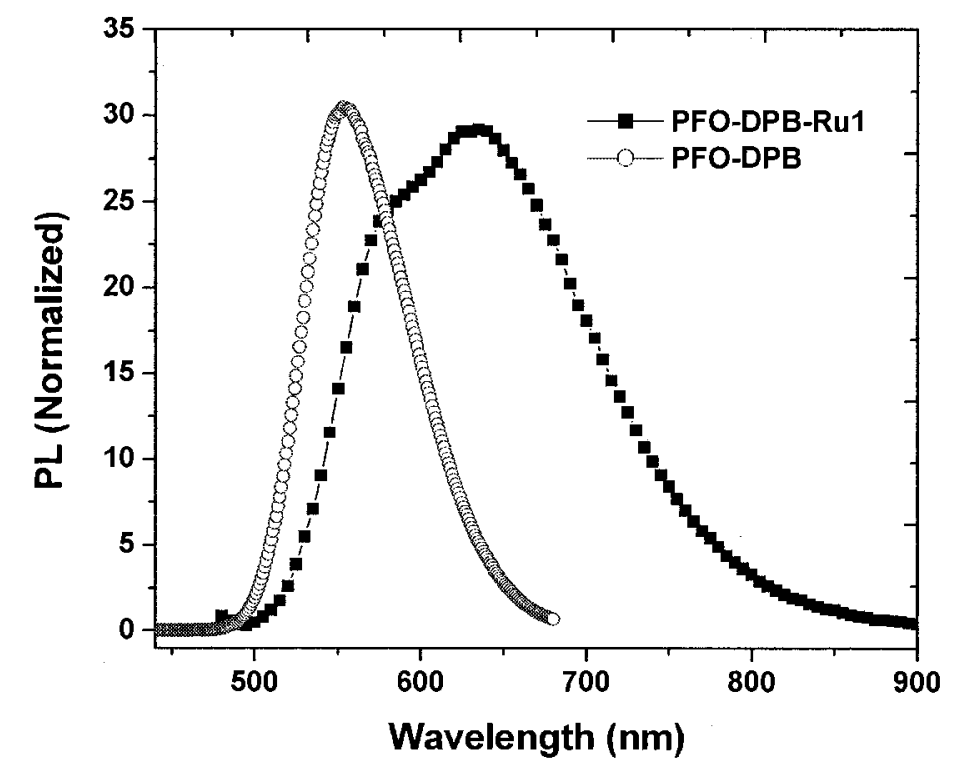

Figure 4.7. PL spectra of PFO-DPB and PFO-DPB-Ru1 in chloroform $(5.0 \times$ $10^{-5} \mathrm{M}$ ) (excitation at $460 \mathrm{~nm}$ ). 


\subsection{Absorption and photoluminescent properties of ligand polymers}

\section{Complexed with other metal ions}

The ion-responsive properties of the two ligand polymers were studied in solution at a polymer concentration of ca. $10^{-5} \mathrm{M}$. Alkali $\left(\mathrm{Li}^{+}\right)$, alkaline earth $\left(\mathrm{Mg}^{2+}\right)$, transition metal ions $\left(\mathrm{Ag}^{+}, \mathrm{Co}^{2+}, \mathrm{Cu}^{2+}, \mathrm{Hg}^{2+}, \mathrm{Ni}^{+}, \mathrm{Pb}^{2+}, \mathrm{Zn}^{2+}\right.$ and $\left.\mathrm{Pd}^{2+}\right)$ and rare-earth metal ions $\left(\mathrm{Eu}^{3+}\right.$ and $\left.\mathrm{Er}^{3+}\right)$ were tested.

Most of alkali, alkaline earth, transition and rare-earth metal ions (40 mol per $1 \mathrm{~mol}$ of the repeating unit) tested with ligand polymers only had a minimum effect on the PL emission of the polymers (Figure 4.8). However, the polymers are very sensitive to some of the transition metal ions. For example, Figure 4.9 shows the UV-vis and PL changes of PFO-DPB upon addition of $\mathrm{Pd}^{2+}$ at various concentrations. The absorption peak shifted from 460 to $500 \mathrm{~nm}$ (Figure 4.9a) and PL intensity of PFO-DPB steeply decreased in the presence of $\mathrm{Pd}^{2+}$ (Figure $4.9 \mathrm{~b}$ ). These changes are due to chelation of dpb unit to $\mathrm{Pd}^{2+}$. Transition metal ions, $\mathrm{Ag}^{+}$, $\mathrm{Cu}^{2+}, \mathrm{Ni}^{+}$, and $\mathrm{Pd}^{2+}$, produce a strong fluorescent quenching to PFO-DPB. Especially, with $\mathrm{Ag}^{+}$and $\mathrm{Pd}^{2+}$ the emission of PFO-DPB is completely quenched $\left(\mathrm{I}_{0} / \mathrm{I}>100\right)$ at the molar ratio of $40: 1$ (metal ion: repeating unit of the polymers). The PL of PDPB is also strongly quenched by $\mathrm{Ag}^{+}$and $\mathrm{Pd}^{2+}$. This quenching effect is believed to be related to energy transfer from the excited state of the polymer moiety to metal complexes. 

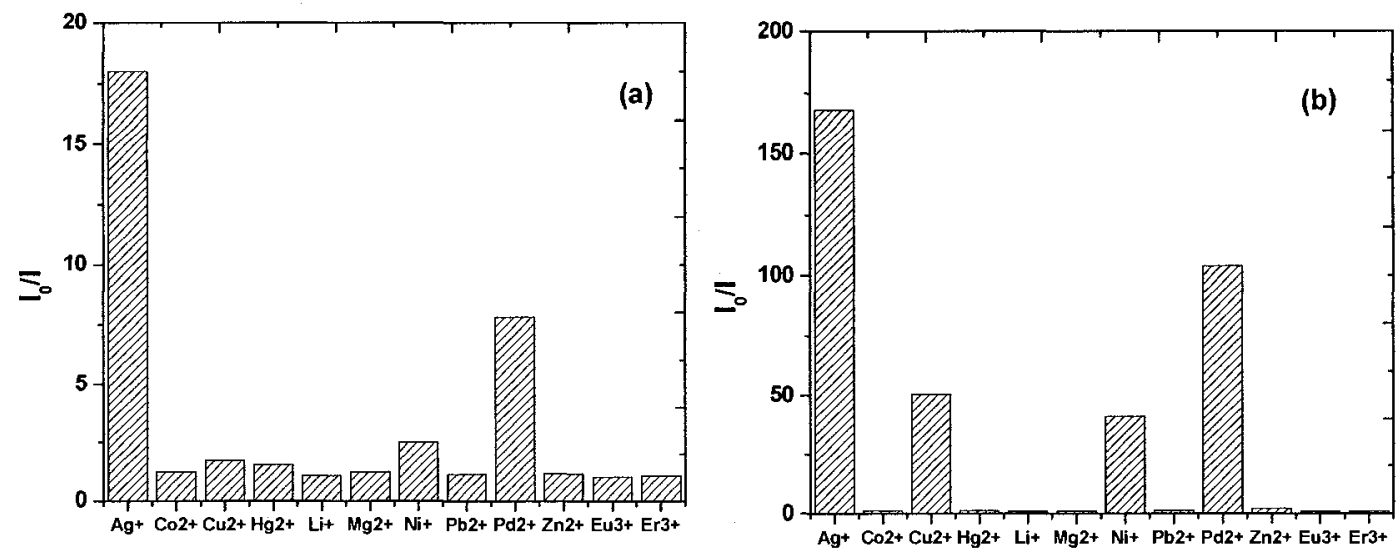

Figure 4.8. PL intensity changes of (a) PDPB $\left(5.1 \times 10^{-5} \mathrm{M}\right)$ in DMF-methanol (10:1) and (b) PFO-DPB $\left(3.5 \times 10^{-5} \mathrm{M}\right)$ in THF-methanol (10:1) after addition of various metal ions at the molar ratio of 40:1 (metal ion: repeating unit of the polymers) $\left(\mathrm{I}_{0}=\mathrm{PL}\right.$ intensity of pure polymer solution. $\mathrm{I}=\mathrm{PL}$ intensity of the polymer solution after chelating with metal ions).
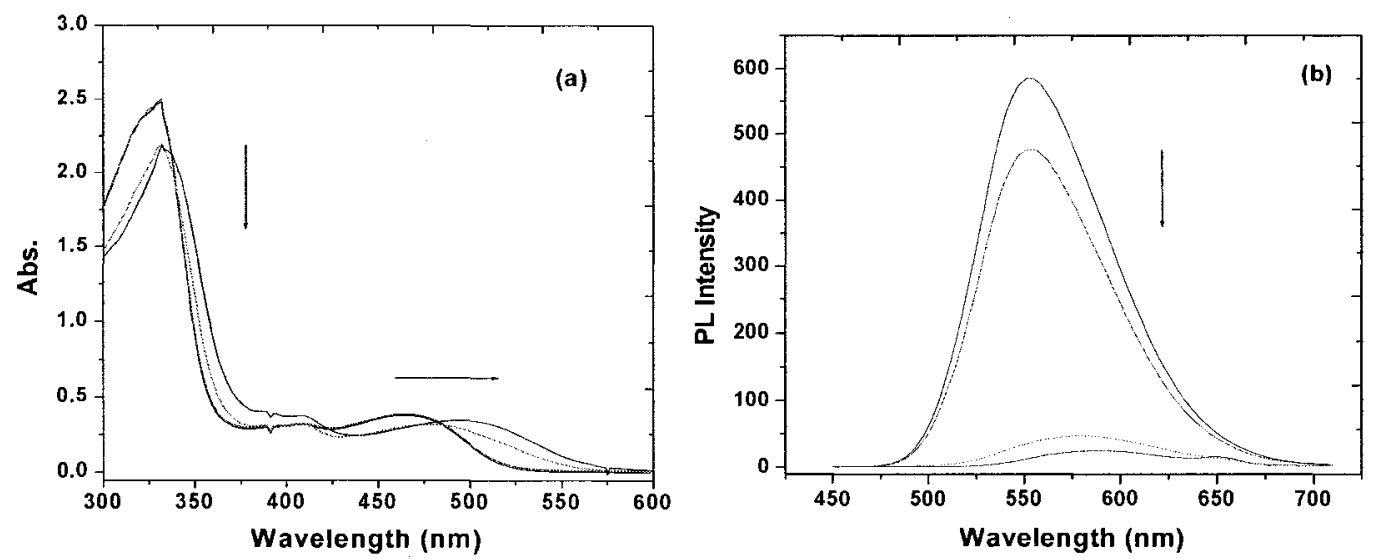

Figure 4.9. Changes in (a) UV-vis absorption and (b) PL spectra of PFO-DPB $\left(3.5 \times 10^{-5}\right)$ in THF-methanol $(10: 1)$ at various concentrations of $\mathrm{PdCl}_{2} \cdot\left[\mathrm{PdCl}_{2}\right]=$ $0,4.52 \times 10^{-5}, 2.15 \times 10^{-4}, 1.40 \times 10^{-3} \mathrm{M}$. Arrows indicate the direction of the change from low to high concentration.

Since both polymers have high sensitivity to $\mathrm{Ag}^{+}$, titration experiments were conducted for both of polymers at a concentration of $5.0 \times 10^{-5} \mathrm{M}$. The corresponding titration curves for PDPB and PFO-DPB are depicted in Figure 4.10. The response of PFO-DPB to $\mathrm{Ag}^{+}$is more apparent than that of PDPB. The 
fluorescence of PFO-DPB could be completely quenched by $\mathrm{Ag}^{+}$at a low concentration of $5 \mathrm{ppm}$. However, with a concentration of $\mathrm{Ag}^{+}$at $40 \mathrm{ppm}$, the PL of PDPB still could not be totally quenched. It shows clearly in Figure 4.8 that PL of PFO-DPB is much easier to be quenched by metal ions relative to PDPB. However, PDPB has a better selectivity than PFO-DPB. PDPB only responds well to $\mathrm{Ag}^{+}$and $\mathrm{Pd}^{2+}$. Since the metal binding sites in both polymers are the same, these results reveal that the backbone structures play an important role in the response of the polymers to metal ions. PDPB shows the higher selectivity due to the larger steric hindrance, which makes the chelation with metal ions more difficult. PFO-DPB's backbone is more flexible and its binding site is less sterically hindered, which leads to a facile chelation with metal ions and results in a higher sensitivity. Moreover, PFO-DPB has a longer conjugation along its backbone with respect to PDPB, which can better amplify the sensory signal. ${ }^{2}$

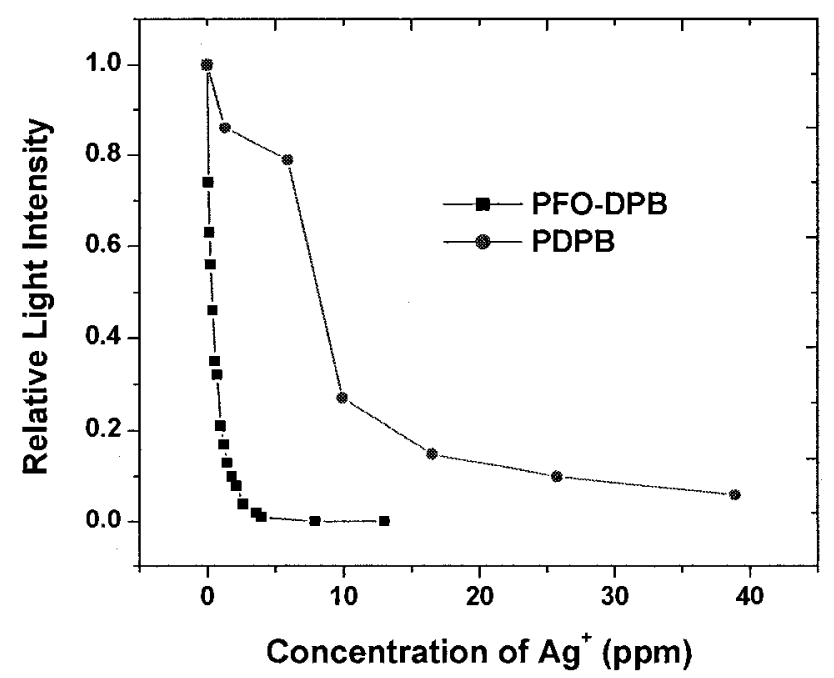

Figure 4.10. Changes in PL intensity of PFO-DPB and PDPB by titration with $\mathrm{Ag}^{+}$. Concentration of polymer solution: $5.0 \times 10^{-5} \mathrm{M}$. 
In addition, some transition metal ions produce a red shift of absorption and PL spectra of the polymers. For instance, absorption and PL spectra of PFO-DPB were red-shifted by 8 and $25 \mathrm{~nm}$, respectively, upon addition of $\mathrm{Zn}^{2+}$, without a noticeable quenching of PL. The spectral red shift is attributed to the conjugation enhancement of the polymer backbone induced by the coordination of metal ions with dpb units. ${ }^{4 a}$ For different metal ions, the differences in the changed spectra reflect a different coordination ability of metal ions to the dpb units.

\subsection{Conclusion}

Two conjugated polymers, PDPB and PFO-DPB, containing dpb unit were synthesized and their photophysical properties were characterized. Their absorption and PL are responsive to acid and some transition metal ions.

Differences in sensitivity and selectivity towards some metal ions were observed between these two polymers. For PDPB, large steric hindrance of the binding sites makes it difficult to chelate with metal ions, which enhances its selectivity. On the contrary, in order to obtain high sensitivity, less steric hindrance helps to facilitate chelation with metal ions. The extended conjugation in polymer backbone is able to amplify the responsive signal. 


\subsection{Experiments}

\section{Materials}

2,2'-Pyridil (97\%), 9,9-dioctylfluorene-2,7-bis(trimethyleneborate) (97\%), tetrakis(triphenylphosphine)palladium(0) $(99 \%)$ and $\mathrm{Ni}(\mathrm{COD})_{2}$ were purchased from Aldrich Chemical Canada and used as received.

\section{Measurements}

The molecular weights of the polymers were measured by gel permeation chromatography (GPC) using polystyrene standards and THF as an eluent for PFO-DPB and DMF as an eluent for PDPB.

The UV/vis and PL spectra of the polymers were measured on a Perkin Elmer Lambda 900 UV/Vis/NIR spectrophotometer and a Shimadzu RF-1501 spectrophotometer, respectively. The films were prepared from dilute THF solution.

Thermogravimetric analysis (TGA) of the polymers was performed using Perkin-Elmer TGA-7 at a heating rate of $20^{\circ} \mathrm{C} / \mathrm{min}$ under a nitrogen atmosphere.

The ${ }^{1} \mathrm{H}$ NMR and ${ }^{13} \mathrm{C}$ NMR spectra were obtained on Bruker Avance-300 and chemical shifts were reported in ppm using tetramethylsilane (TMS) as an internal standard.

Titration experiment: The THF solution for PFO-DPB and DMF solution for PDPB at a concentration of ca. $5.0 \times 10^{-5} \mathrm{M}$ were prepared. A solution of given metal ion $(0.1 \mathrm{M}$ in methanol) was introduced into the polymer solution via a 
Nichipet-ex pipette $(10-100 \mu \mathrm{L})$. The resulting solution was sonicated for $1 \mathrm{~min}$, left on standing for $1 \mathrm{~min}$ before taking the UV-vis and PL spectra.

\section{1,4-Dibromo-2,3-diaminoaphthalene (4.1)}

A mixture of bromine $(2.36 \mathrm{~g}, 14.7 \mathrm{mmol})$ and $20 \mathrm{~mL}$ of glacial acetic acid was added dropwise into a solution of 2,3-diaminophthalene $(1.04 \mathrm{~g}, 6.58 \mathrm{mmol})$ in $30 \mathrm{~mL}$ of glacial acid, with vigorous stirring at room temperature. After $1 \mathrm{~h}$, the precipitate was filtered and washed subsequently with $50 \mathrm{~mL}$ of glacial acetic acid, $100 \mathrm{~mL}$ of $2 \mathrm{wt} \% \mathrm{Na}_{2} \mathrm{CO}_{3}$ solution, and $100 \mathrm{~mL}$ of water. A yellow powder was obtained after drying. The yield was $1.78 \mathrm{~g}(85.6 \%) .{ }^{1} \mathrm{H}$ NMR $\left(300 \mathrm{MHz}, \mathrm{CDCl}_{3}\right)$ : $\delta 8.02(\mathrm{q}, 2 \mathrm{H}), 7.41(\mathrm{q}, 2 \mathrm{H}), 4.33(\mathrm{~s}, 4 \mathrm{H}) ;{ }^{13} \mathrm{C} \mathrm{NMR}\left(75 \mathrm{MHz}, \mathrm{CDCl}_{3}\right): \delta 134.94$, 128.27, 126.08, 125.43, 106.90; EI-MS $m / z$ (\% relative intensity): $315.9\left(100, \mathrm{M}^{+}\right)$, $237(2.5), 181(15.2) ; \mathrm{mp} 95-97^{\circ} \mathrm{C}$.

5,10-Dibromo-2,3-bis(2-pyridyl)benzoquinoxaline (4.2)

A mixture of 1,4-dibromo-2,3-diaminonaphthalene $(2.0 \mathrm{~g}, 6.3 \mathrm{mmol})$ and 2,2'-pyridil $(1,3 \mathrm{~g}, 6.3 \mathrm{mmol})$ in $120 \mathrm{~mL}$ of anhydrous ethanol was heated at reflux overnight under argon. The mixture was then cooled to room temperature. The yellow product was collected with a yield of $82 \%$. ${ }^{1} \mathrm{H}$ NMR $\left(300 \mathrm{MHz}, \mathrm{CDCl}_{3}\right): \delta$ $8.72(\mathrm{q}, 2 \mathrm{H}), 8.42(\mathrm{~d}, 2 \mathrm{H}), 8.34(\mathrm{~d}, 2 \mathrm{H}), 7.96(\mathrm{t}, 2 \mathrm{H}), 7.76(\mathrm{q}, 2 \mathrm{H}), 7.31(\mathrm{q}, 2 \mathrm{H}) ;{ }^{13} \mathrm{C}$ NMR $\left(75 \mathrm{MHz}, \mathrm{CDCl}_{3}\right): \delta 156.7,153.6,148.1,137.0,135.8,133.4,128.8,128.5$, 
124.8, 124.5, 123.5; EI-MS $m / z$ (\% relative intensity): $491.0\left(100, \mathrm{M}^{+}\right), 411$ (15.4), $169(48), 119(96.7) ; \mathrm{mp} 280-281^{\circ} \mathrm{C}$.

Poly[5,10-(2,3-bis(2-pyridyl)benzoquinoxaline)] (PDPB)

A mixture of 5,10-dibromo-2,3-bis(2-pyridyl)benzoquinoxaline (4.2) (1.0 $\mathrm{g}, 2.0 \mathrm{mmol}), \mathrm{Ni}(\mathrm{COD})_{2}(0.67 \mathrm{~g}, 2.4 \mathrm{mmol})$, and 2,2'-bipyridyl $(0.41 \mathrm{~g}, 2.6 \mathrm{mmol})$ in $20 \mathrm{~mL}$ of anhydrous DMF was heated at reflux for $26 \mathrm{~h}$. The dark green, viscous mixture was precipitated from $20 \mathrm{~mL}$ of THF. The solid was collected by filtration, dissolved in $5 \mathrm{~mL}$ of DMF and then precipitated from $20 \mathrm{~mL}$ of THF. The green final product was collected with a yield of $71 \%$. ${ }^{1} \mathrm{H}$ NMR (300 MHz, $\left.\mathrm{d}_{6}-\mathrm{DMSO}\right): \delta$ 8.03 (br, 5H), 7.64 (br, 5H) and $7.06(\mathrm{br}, 2 \mathrm{H}) ;{ }^{13} \mathrm{C}$ NMR (75 MHz, $\left.\mathrm{d}_{6}-\mathrm{DMSO}\right): \delta$ $157.36,153.38,152.56,148.28,137.20,134.42,129.77,128.27,127.94,123.87$, 123.30; IR $\left(\mathrm{KBr}, \mathrm{cm}^{-1}\right)$ : 3054 (aromatic $\left.\mathrm{C}-\mathrm{H}\right), 1586,1472$ (aromatic C=C); GPC: $M_{\mathrm{n}} 3500, M_{\mathrm{w}} 6020$, PDI $1.72 ;$ DSC: $T_{\mathrm{d}} 280^{\circ} \mathrm{C}$.

Poly[2,7-(9,9-dioctylfluorene)-co-5,10-(2,3-bis(2-pyridyl)benzoquinoxaline)]

(PFO-DPB)

A mixture of 9,9-dioctylfluorene-2,7-bis(trimethyleneborate) $(0.57 \mathrm{~g}, 1.0$ $\mathrm{mmol})$, 5,10-dibromo-2,3-bis(2-pyridyl) benzoquinoxaline (4.2) $(0.50 \mathrm{~g}, 1.0$ $\mathrm{mmol}),\left(\mathrm{PPh}_{3}\right)_{4} \mathrm{Pd}(0)(0.012 \mathrm{~g}, 0.05 \mathrm{mmol})$ and several drops of Aliquat 336 in a mixture of $15 \mathrm{~mL}$ of THF and $4 \mathrm{~mL}$ of $2 \mathrm{M} \mathrm{Na}_{2} \mathrm{CO}_{3}$ solution was refluxed with vigorous stirring for $72 \mathrm{~h}$ under an argon atmosphere. At the end of polymerization, 
phenylboronic acid $(0.033 \mathrm{~g}, 0.10 \mathrm{mmol})$ was added to remove bromine end groups. After $5 \mathrm{~h}$, bromobenzene $(0.031 \mathrm{~g}, 0.20 \mathrm{mmol})$ was added as a monofunctional end-capping reagent to remove boracic ester end group. The mixture was then poured into methanol. The solid was collected. Then it was dissolved in $5 \mathrm{~mL}$ of THF and precipitated from $50 \mathrm{~mL}$ of methanol with a yield of $76 \%$. ${ }^{1} \mathrm{H}$ NMR (300 $\left.\mathrm{MHz}, \mathrm{CDCl}_{3}\right): \delta 8.14(\mathrm{br}, 7 \mathrm{H}), 7.74(\mathrm{br}, 8 \mathrm{H}), 7.18(\mathrm{br}, 3 \mathrm{H}), 2.14(\mathrm{br}, 4 \mathrm{H}), 1.18(\mathrm{br}$, $24 \mathrm{H}), 0.83(\mathrm{br}, 6 \mathrm{H}) ;{ }^{13} \mathrm{C} \mathrm{NMR}\left(75 \mathrm{MHz}, \mathrm{CDCl}_{3}\right): \delta 158.08,151.58,150.73,147.71$, $140.39,139.01,136.61,136.20,135.34,133.17,131.06,127.25,126.99,126.33$, $123.81,122.71,119.22,55.40,40.39,31.91,30.25,29.54,24.36,22.62,14.12$; IR $\left(\mathrm{KBr}, \mathrm{cm}^{-1}\right): 3062\left(\right.$ aromatic C-H), 2926 (aliphatic $\mathrm{CH}_{2}$ ), 1587, 1468 (aromatic $\mathrm{C}=\mathrm{C}), 1384\left(\mathrm{CH}_{3}\right)$; GPC: $M_{\mathrm{n}} 10048, M_{\mathrm{w}} 15$ 537, PDI 1.54; DSC: $T_{\mathrm{d}} 430^{\circ} \mathrm{C}$.

\section{General Procedure for Complexation of PFO-DPB}

PFO-DPB-Ru1: A solution of $\mathrm{Ru}(\mathrm{acac})_{2}\left(\mathrm{CH}_{3} \mathrm{CN}\right)_{2}(0.03 \mathrm{~g}, 0.07 \mathrm{mmol})$, and PFO-DPB $(0.10 \mathrm{~g}, 0.14 \mathrm{mmol})$ in $10 \mathrm{~mL}$ of THF and $4 \mathrm{~mL}$ of DMF was heated at reflux for $48 \mathrm{~h}$ under argon. After cooling to room temperature, the reaction mixture was concentrated and then was poured into methanol. The precipitated material was filtered and washed with acetone to remove unreacted ruthenium residues. Yield: $79 \%$. Ruthenium content: $3.24 \%$. 
PFO-DPB-Ru2: $\mathrm{Ru}(\mathrm{acac})_{2}\left(\mathrm{CH}_{3} \mathrm{CN}\right)_{2}(0.06 \mathrm{~g}, 0.14 \mathrm{mmol})$, PFO-DPB $(0.10$

g, $0.14 \mathrm{mmol}$ ), $5 \mathrm{~mL}$ of THF and $10 \mathrm{~mL}$ of DMF. Yield: $68 \%$. Ruthenium content: $7.58 \%$.

PFO-DPB-Ru3: $\mathrm{Ru}(\mathrm{acac})_{2}\left(\mathrm{CH}_{3} \mathrm{CN}\right)_{2}(0.17 \mathrm{~g}, 0.44 \mathrm{mmol})$, PFO-DPB $(0.15$ g, $0.20 \mathrm{mmol}$ ), $10 \mathrm{~mL}$ of THF and $25 \mathrm{~mL}$ of DMF. Yield: $45 \%$. Ruthenium content: $11.4 \%$ 


\section{References}

1. (a) S. Flores-Torres, G. R. Hutchison, L. J. Soltzberg, H. D. Abruña, J. Am. Chem. Soc. 2006, 128, 1513. (b) M. I. J. Polson, S. L. Howell, A. H. Flood, A. K. Burrell, A. G. Blackman, K. C. Gordon, Polyhedron 2004, 23, 1427. (c) T. Renouard, R. A. Fallahpour, Md. K. Nazeeruddin, R. Humphry-Baker, S. I. Gorelsky, A. B. P. Lever, M. Grätzel, Inorg. Chem. 2002, 41, 367. (d) P. K. Ng, X. Gong, W. Wong, W. K. Chan, Macromol. Rapid Commun. 1997, 18, 1009. (e) T. Yasuda, T. Yamamoto, Macromolecules 2003, 36, 7513. (f) T. Yasuda, I. Yamaquchi, T. Yamamoto, Adv. Mater. 2003, 15, 293. (g) S. Wang, X. Li, S. Xun, X. Wan, Z. Y. Wang, Macromolecules 2006, 39, 7502.

2. (a) Q. Zhou, T. M. Swager, J. Am. Chem. Soc. 1995, 117, 12593. (b) T. M. Swager, Acc. Chem. Res. 1998, 31, 201.

3. (a) S. M. Molnar, K. R. Neville, G. E. Jensen, K. J. Brewer, Inorg. Chim. Acta 1993, 206, 69. (b) M. Richter, K. J. Brewer, Inorg. Chim. Acta 1991, 180, 125. (c) D. M. D'Alessandro, L. S. Kelso, F. R. Keene, Inorg. Chem. 2001, 40,6841 .

4. (a) B. Wang, M. R. Wasielewski, J. Am. Chem. Soc. 1997, 119, 12. (b) L. X. Chen, W. J. H. Jäger, D. J. Gosztola, J. Phys. Chem. B 2000, 104, 1950.

5. J. Yang, C. Jiang, Y. Zhang, R. Yang, W. Yang, Q. Hou, Y. Cao, Macromolecules 2004, 37, 1211.

6. (a) T. Yamamotoa, Y. Fujiwaraa, H. Fukumotoa, Y. Nakamuraa, S. 
Koshiharab, T. Ishikawab, Polymer 2003, 44, 4487. (b) T. Yamamoto, A. Morita, Y. Miyazaki, T. Maruyama, H. Wakayama, Z. Zhou, Y. Nakamura, T. Kanbara, S. Sasaki, K. Kubota, Macromolecules 1992, 25, 1214. (c) Z. Zhang, M. Fujiki, H. Tang, M. Motonaga, K. Torimitsu. Macromolecules 2002, 35, 1988. (d) L. Tan, M. D. Curtis, A. H. Francis, Macromolecules $\mathbf{2 0 0 2}, 35,4628$.

7. (a) H. Tong, L. Wang, X. Jing, F. Wang, Macromolecules 2002, 35, 7169. (b) A. S. Shetty, E. B. Liu, R. J. Lachicotte, S. A. Jenekhe, Chem. Mater. 1999, 11, 2292. (c) Q. T. Zhang, L. M. Tour, J. Am. Chem. Soc. 1997, 119, 9624. (d) D.-K. Fu, B. Xu, T. M. Swager, Tetrahedron 1997, 53, 15487.

8. (a) Schulz, M. Bruma, L. Brehmer, Adv. Mater. 1997, 9, 601. (b) C. T. Wong, W. K. Chan, Adv. Mater. 1998, 11, 455. 


\section{Contribution to Knowledge}

1. The working principle of a new NIR optical sensor for hydrogen peroxide based on the NIR-absorbing ruthenium complexes is demonstrated.

2. The use of electrochemically modulated energy transfer of DCH-Ru complexes to control the emission of redox-inactive fluorescent dyes is demonstrated.

3. The EL over $1000 \mathrm{~nm}$ has been achieved by tuning the bandgap of the ruthenium complexes. 
Appendix

${ }^{1} \mathrm{H}$ and ${ }^{13} \mathrm{C}$ NMR Spectra of Some New Ligands 
L2<smiles>CCCNC(=O)NNC(=O)OCC</smiles>

${ }^{1} \mathrm{H}$ NMR (300 MHz, $\mathrm{d}_{6}$-DMSO)
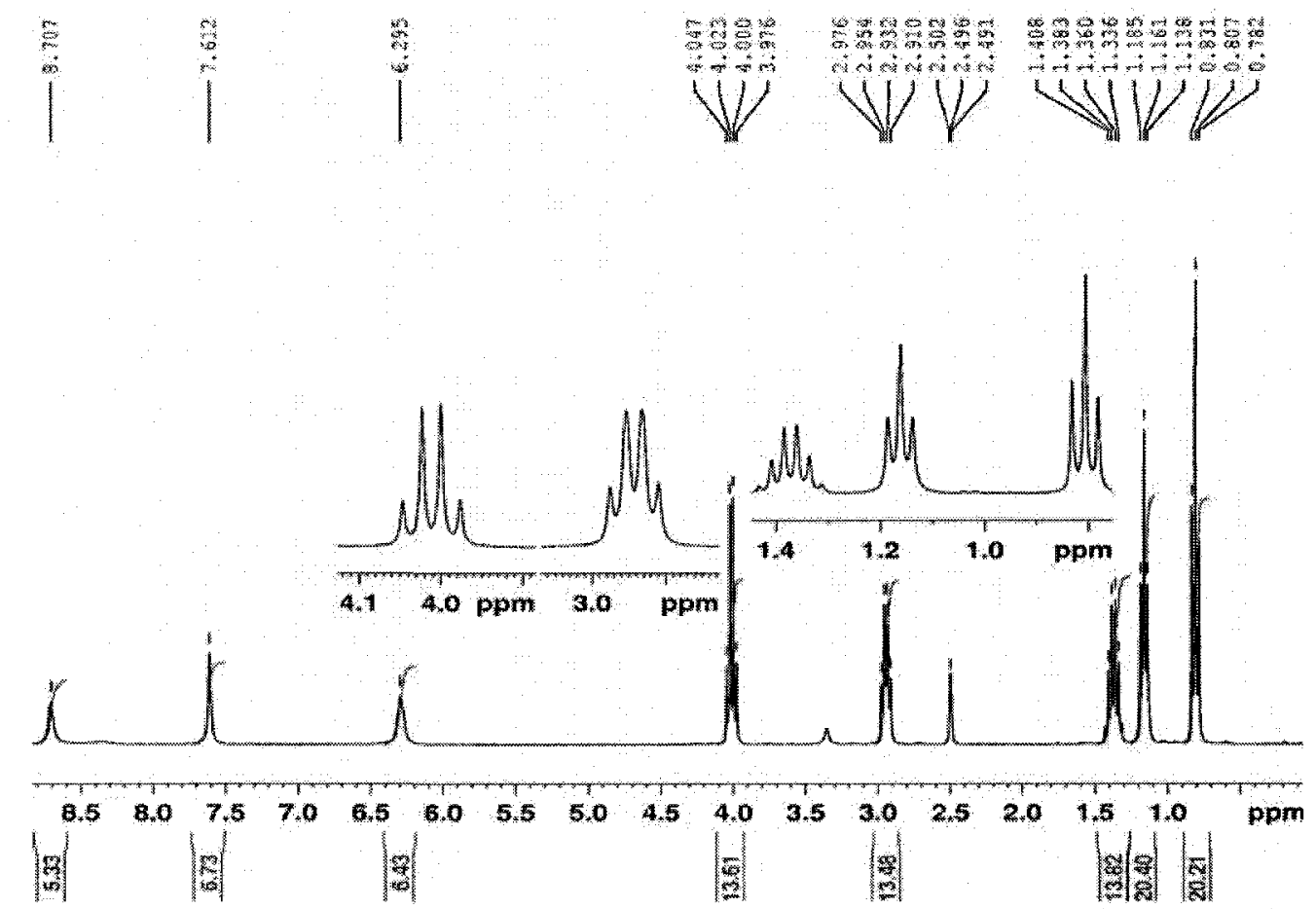

${ }^{13} \mathrm{C}\left(\mathrm{NMR}, 75 \mathrm{MHz}, \mathrm{d}_{6}\right.$-DMSO )

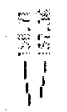
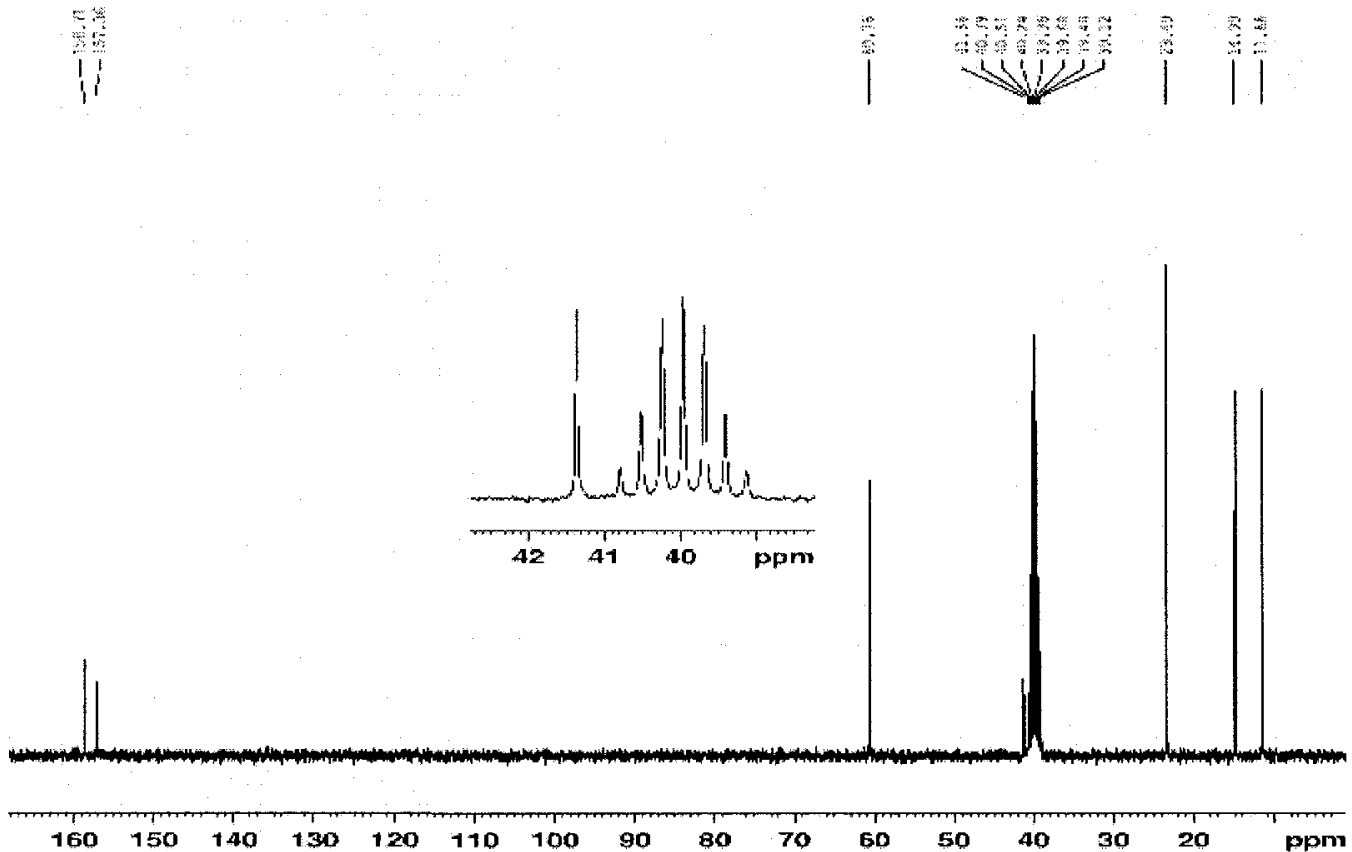
L3<smiles>CCOC(=O)NNC(=O)OCC</smiles>

${ }^{1} \mathrm{H}$ NMR (300 MHz, $\mathrm{d}_{6}$-DMSO)
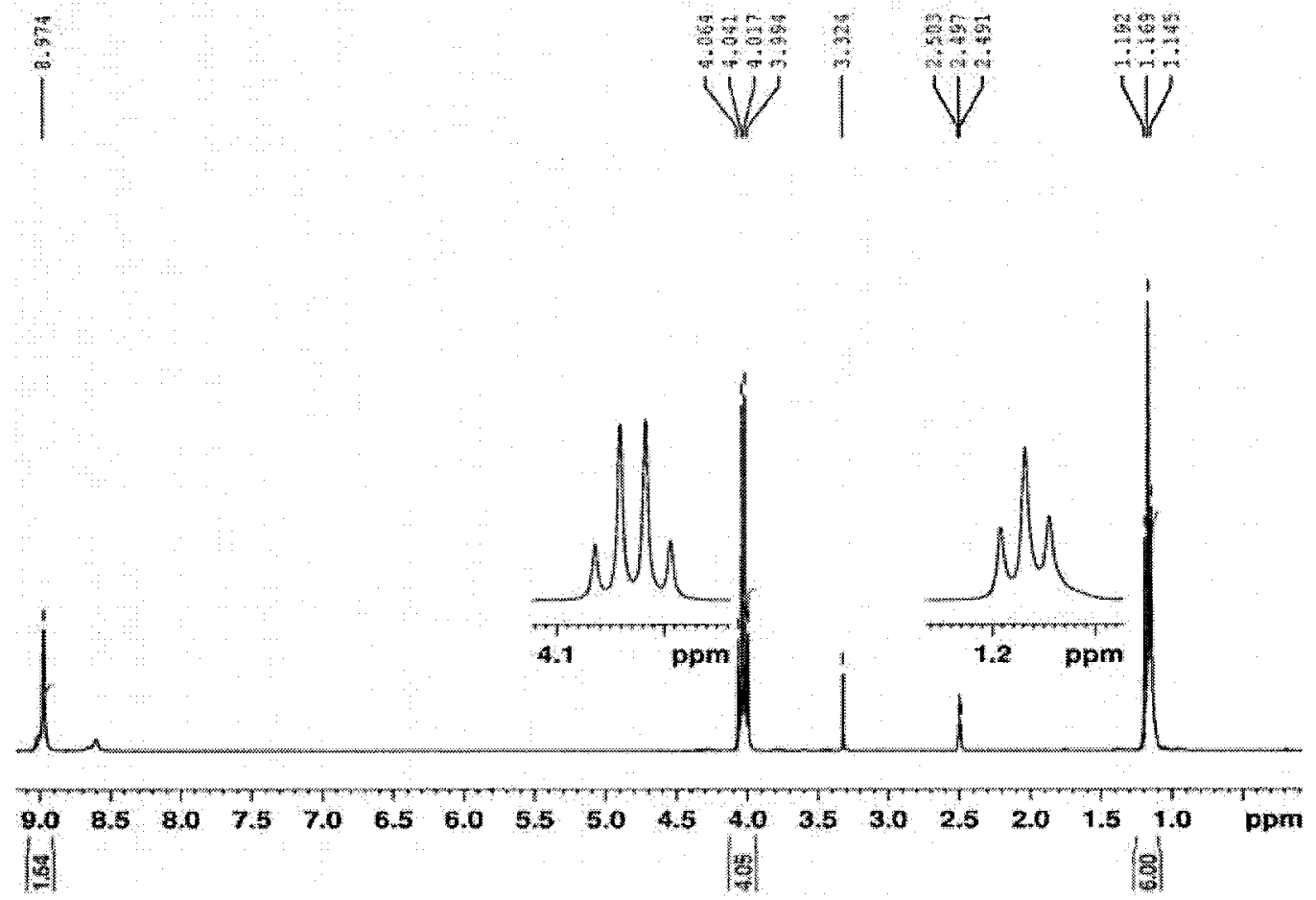

${ }^{13} \mathrm{C}$ NMR (75 MHz, $\mathrm{d}_{6}$-DMSO)
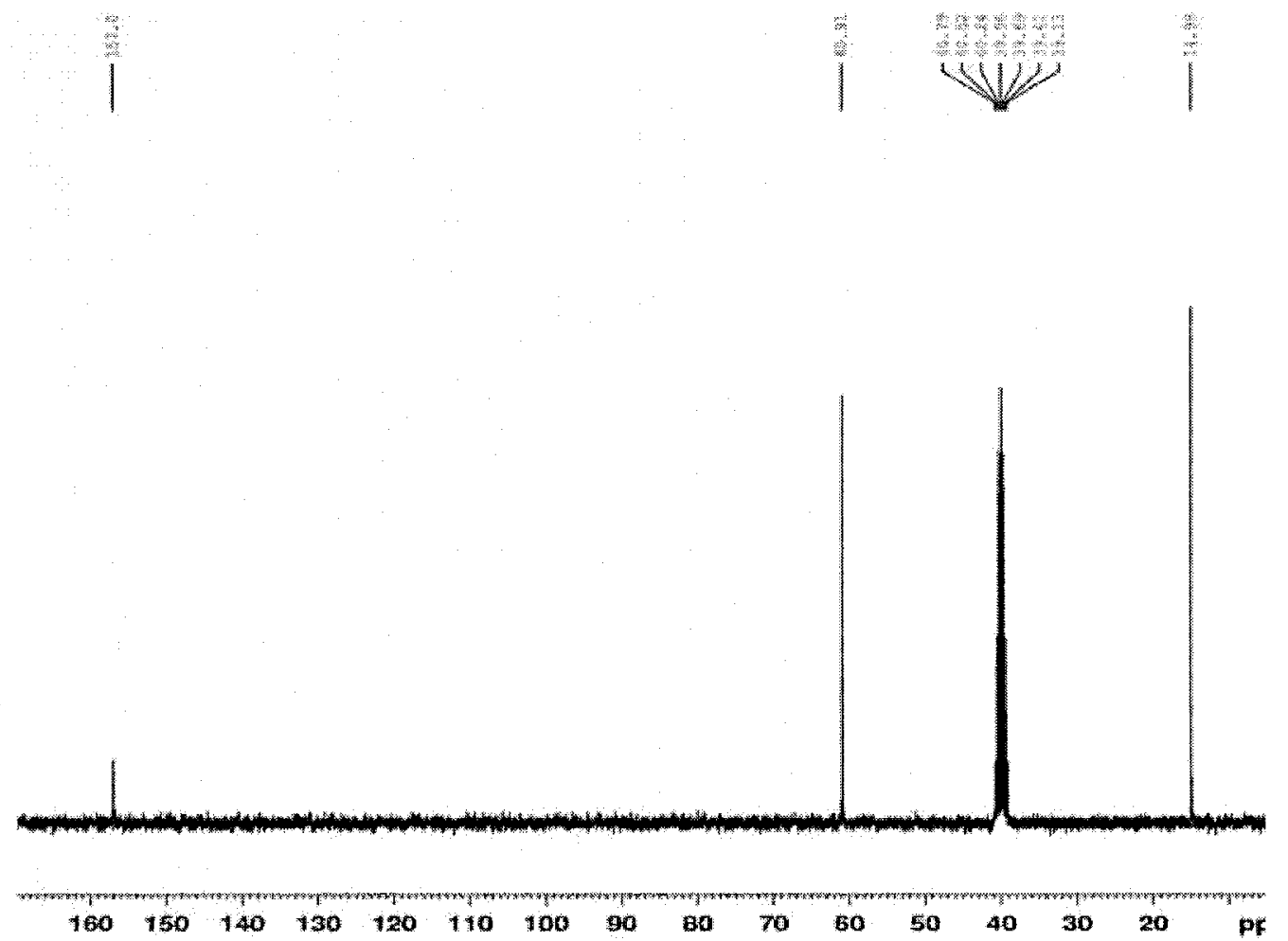
BA-DCH-ph<smiles>O=C(O)CCCC(=O)NNC(=O)c1ccccc1</smiles>

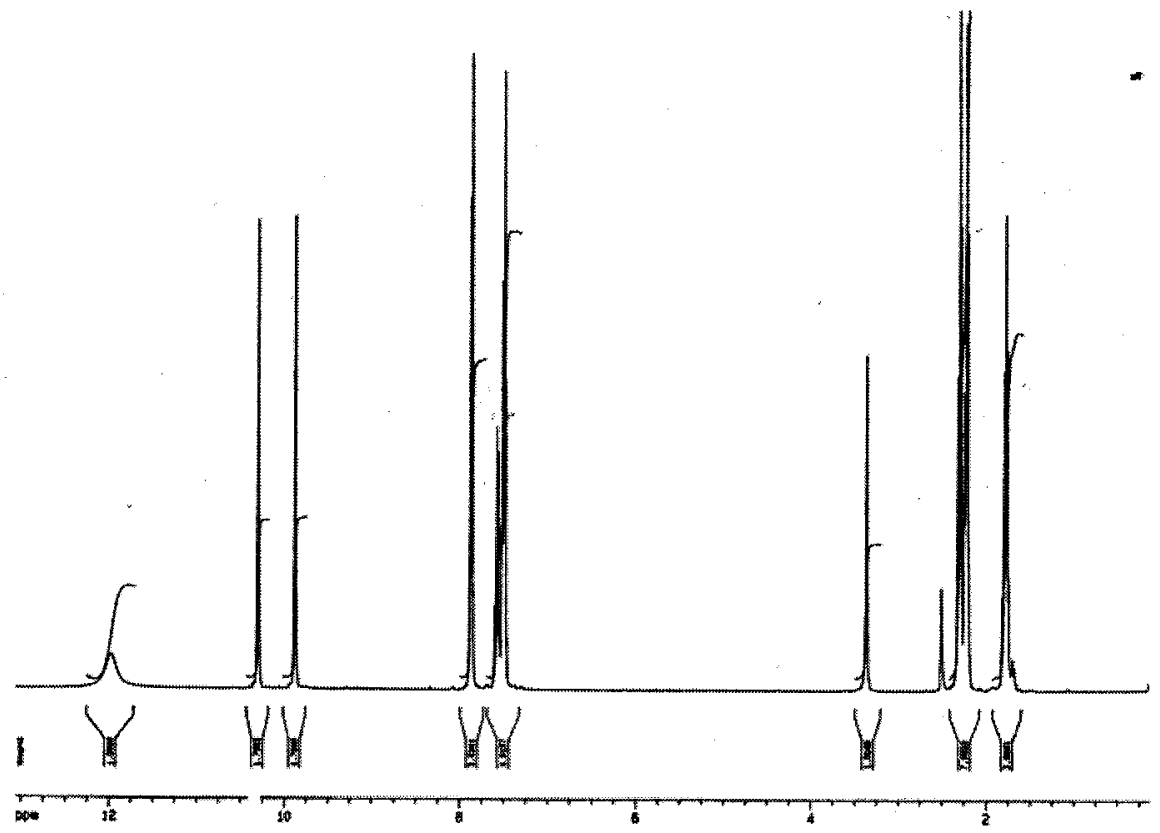

${ }^{13} \mathrm{C}$ NMR (75 MHz, $\mathrm{d}_{6}$-DMSO)

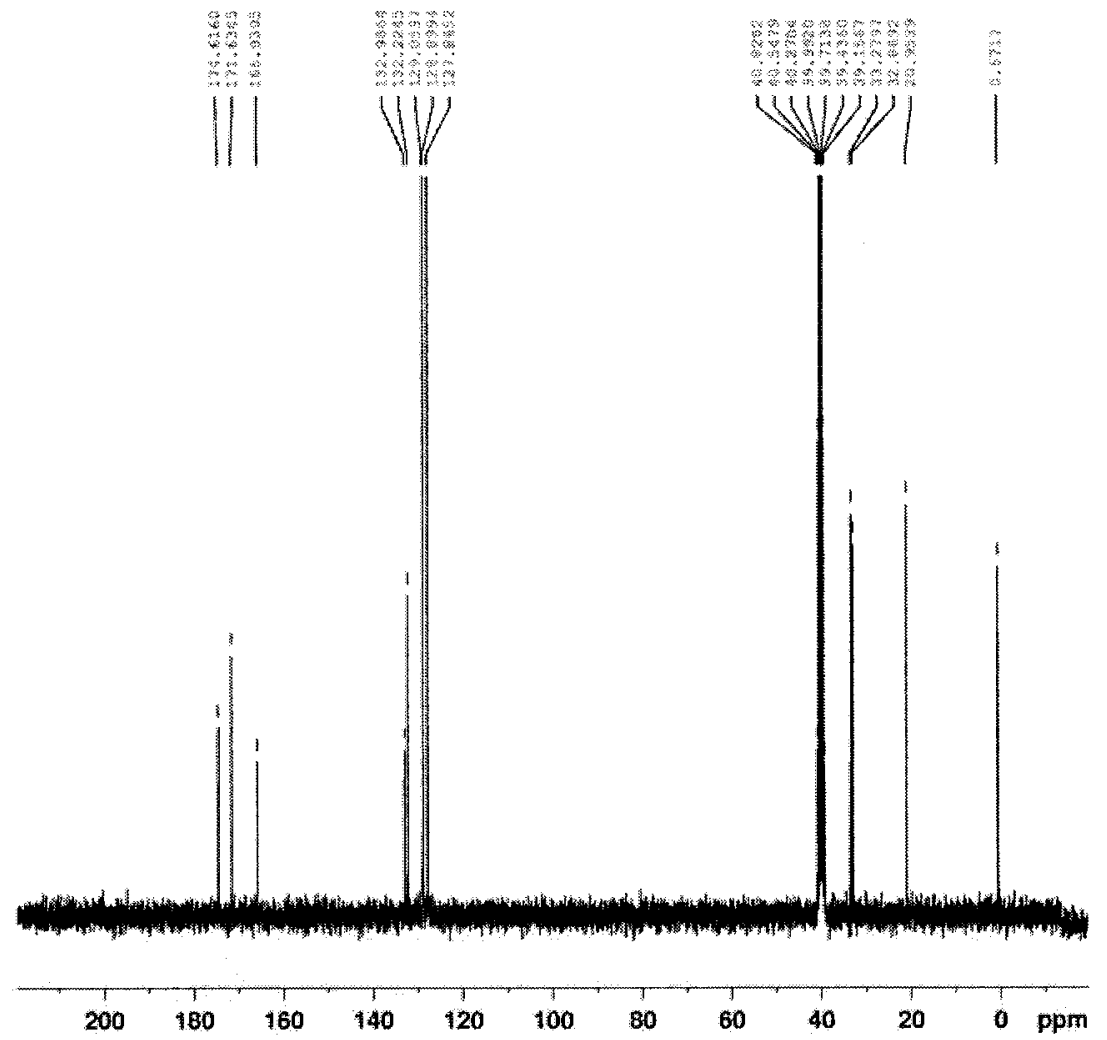


5,10-Dibromo-2,3-bis(2-pyridyl)benzoquinoxaline<smiles>Brc1c2ccccc2c(Br)c2nc(-c3ccccn3)c(-c3ccccn3)nc12</smiles>

${ }^{1} \mathrm{H}$ NMR (300 MHz, $\mathrm{CDCl}_{3}$ )

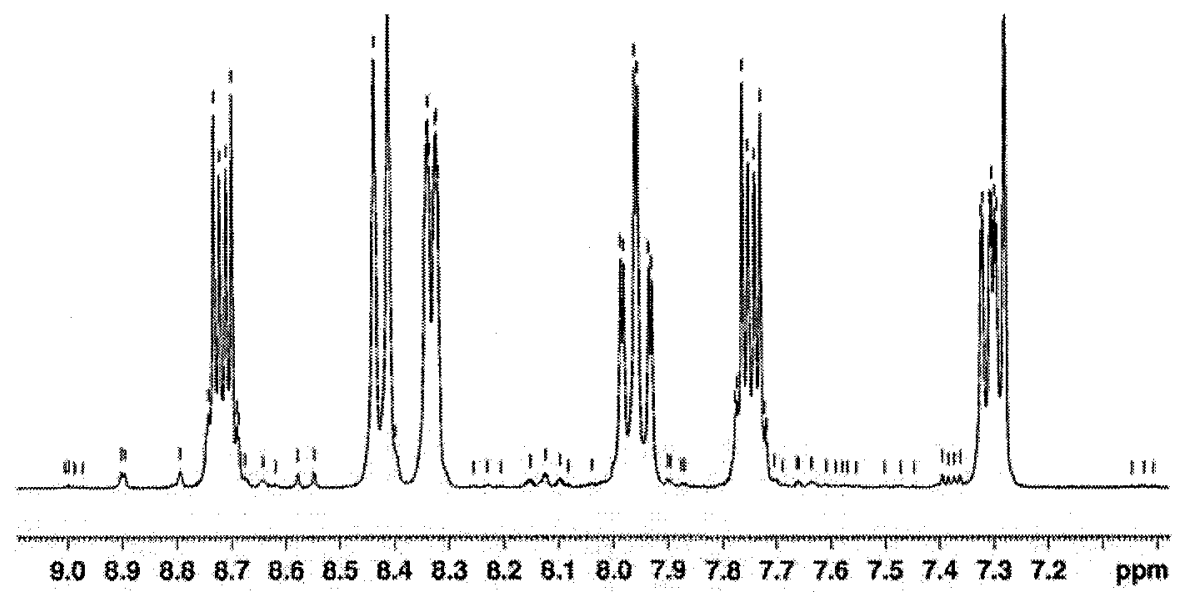

${ }^{13} \mathrm{C}$ NMR $\left(75 \mathrm{MHz}, \mathrm{CDCl}_{3}\right.$ )

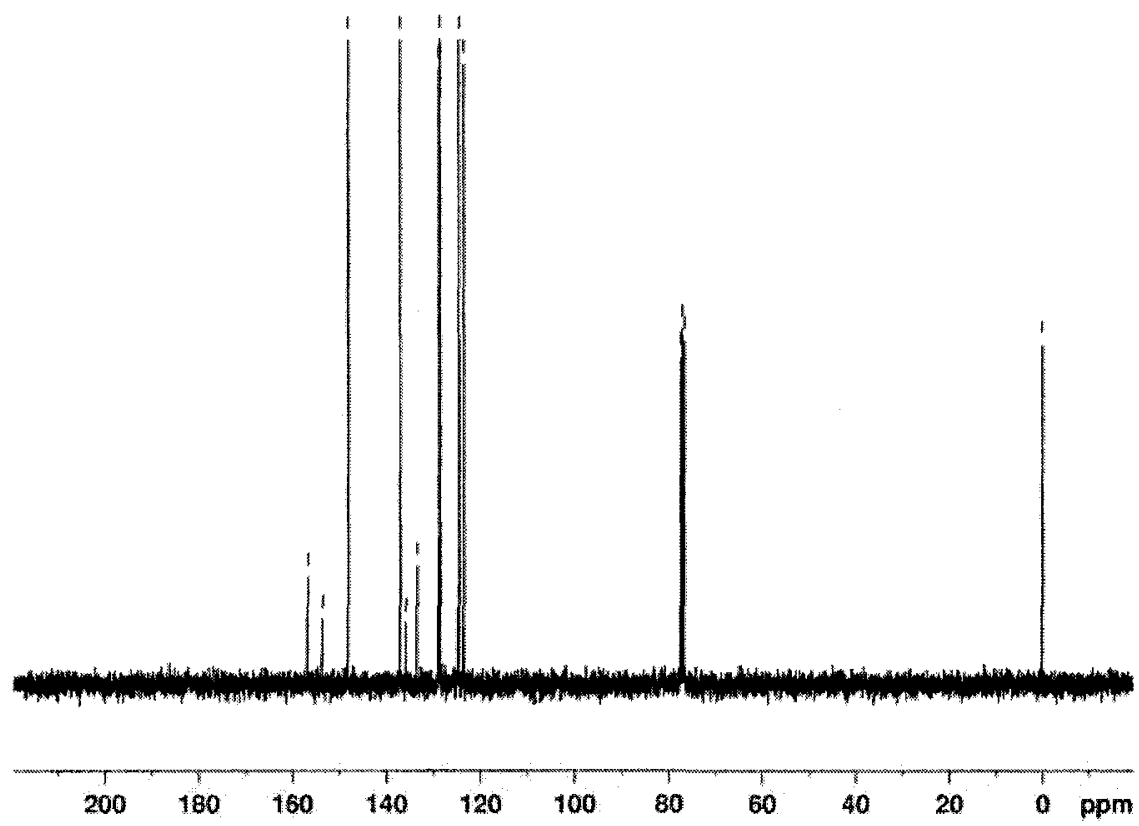

